NOTE TO USERS

This reproduction is the best copy available.

(B)

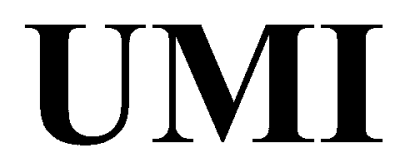





\title{
Neoliberal Global Governance: A Study of How \\ International Development Organizations \\ Transform East African Mediascapes
}

\author{
by
}

Joseph K. Ngare, M.A.

\begin{abstract}
A thesis submitted to
the Faculty of Graduate Studies and Research

in partial fulfillment of

the requirements for the degree of
\end{abstract}

Doctor of Philosophy

School of Journalism and Communication

Facuity of Public Affairs

\author{
Carleton University \\ Ottawa, Ontario \\ May 14, 2008 \\ (C) 2008, Joseph K. Ngare
}




$\begin{array}{ll}\begin{array}{l}\text { Library and } \\ \text { Archives Canada }\end{array} & \begin{array}{l}\text { Bibliothèque et } \\ \text { Archives Canada }\end{array} \\ \begin{array}{l}\text { Published Heritage } \\ \text { Branch }\end{array} & \begin{array}{l}\text { Direction du } \\ \text { Patrimoine de l'édition }\end{array} \\ \begin{array}{l}\text { 395 Wellington Street } \\ \text { Ottawa ON K1A 0N4 } \\ \text { Canada }\end{array} & \begin{array}{l}\text { 395, rue Wellington } \\ \text { Ottawa ON K1A 0N4 } \\ \text { Canada }\end{array}\end{array}$

Your file Votre référence ISBN: 978-0-494-40530-7

Our file Notre référence

ISBN: 978-0-494-40530-7

NOTICE:

The author has granted a nonexclusive license allowing Library and Archives Canada to reproduce, publish, archive, preserve, conserve, communicate to the public by telecommunication or on the Internet, loan, distribute and sell theses worldwide, for commercial or noncommercial purposes, in microform, paper, electronic and/or any other formats.

The author retains copyright ownership and moral rights in this thesis. Neither the thesis nor substantial extracts from it may be printed or otherwise reproduced without the author's permission.
AVIS:

L'auteur a accordé une licence non exclusive permettant à la Bibliothèque et Archives Canada de reproduire, publier, archiver, sauvegarder, conserver, transmettre au public par télécommunication ou par l'Internet, prêter, distribuer et vendre des thèses partout dans le monde, à des fins commerciales ou autres, sur support microforme, papier, électronique et/ou autres formats.

L'auteur conserve la propriété du droit d'auteur et des droits moraux qui protège cette thèse. $\mathrm{Ni}$ la thèse ni des extraits substantiels de celle-ci ne doivent être imprimés ou autrement reproduits sans son autorisation.
In compliance with the Canadian Privacy Act some supporting forms may have been removed from this thesis.

While these forms may be included in the document page count, their removal does not represent any loss of content from the thesis.
Conformément à la loi canadienne sur la protection de la vie privée, quelques formulaires secondaires ont été enlevés de cette thèse.

Bien que ces formulaires aient inclus dans la pagination, il n'y aura aucun contenu manquant.

\section{Canada}




\begin{abstract}
This dissertation investigates how international development organizations are using power, knowledge and practices to transform East African mediascapes. This research focus is neglected by liberal scholarship on African communications transformations as well as global governance theory of communication, specifically, international regime and cosmopolitan governance approaches. Thus, the dissertation re-conceptualizes the global governance concept and draws from the Foucauldian global governmentality perspective. These theoretical shifts offer a language for discussing neoliberal global governance and East African communications transformations in relation to international development organizations' agenda of economic globalization.

The dissertation presents two case studies of economic globalization projects promoted by international development organizations: the African Information Society Initiative and the World Bank's project on communications and development. Using an epistemic genealogical perspective as the research orientation and the research method of critical frame analysis, this study investigates the epistemic foundations of East African communications transformations. The study finds that East African governments and the Daily Nation, leading newspaper in the East African region, are engaged in transforming the World Bank's version of global neoliberalism from a global- to a national-popular mode of thought. The implication of this finding is that East Africans are experiencing inequitable redistribution of media as national resources and loss of epistemic selfgovernance in the issue-area of communications.
\end{abstract}

To transcend the democratic deficits of equity and (epistemic) self-governance in East African mediascapes, the dissertation proposes that existing national communications policies be reviewed. However, it notes that these policies are in operation and that changing them will involve pressure from communications-oriented civil society organizations. These organizations can rise to this challenge if they discard the neoliberal conception of civil society and include the democratization of mediascapes in their agenda. Adoption of these two ideas would set the stage for calls for more humane and egalitarian East African mediascapes. This dissertation, therefore, contributes to knowledge that can be of use to civil society organizations in East Africa. 


\section{Table of Contents}

\section{Introduction}

Mapping the Dissertation $\quad 1$

Definition of Key Concepts $\quad 6$

Economic Globalization $\quad 6$

Global Neoliberalism $\quad 7$

Neoliberal Global Governance $\quad 7$

$\begin{array}{ll}\text { Neoliberalization } & 8\end{array}$

International Development Organizations $\quad 8$

$\begin{array}{ll}\text { East Africa } & 8\end{array}$

$\begin{array}{ll}\text { Mediascapes } & 9\end{array}$

$\begin{array}{ll}\text { Communications Transformations } & 10\end{array}$

$\begin{array}{ll}\text { Studies on African Communications Transformations } & 10\end{array}$

The Liberal Theory of Communications Transformations 15

Global Governmentality, Economic Globalization, and East African Mediascapes 18

Conceptualizing Economic Globalization 20

Economic Globalization as Governmentality 22

Economic Globalization as Neoliberal Global Governance $\quad 22$

Economic Globalization as an "Interpretive Grid" 25

Economic Globalization as Neoliberalization 28

The Democratization Process and Democratic Deficits 31

Loss of Epistemic Self-Governance 33

Inadequate Redistribution of Media Resources 34

Deficient Participation of Citizens 36

Beyond Democratic Deficits $\quad 36$

Overview of Dissertation $\quad 38$ 


\section{Chapter One}

\section{Neoliberal Global Governance, Global Governmentality,}

and East African Communications Transformations

Assessing the Global Governance Theory of Communication 49

The International Regime Approach 50

The Cosmopolitan Governance Approach 51

The Blind Spots of the Westphalian Approaches 54

The Concept and Phenomenon of Neoliberal Global Governance 56

The Etymological Roots of Global Governance 57

The Strands of Global Governance Phenomenon 57

The Evolution of Neoliberal Global Governance 59

The Global Governmentality Perspective 66

Political Rationality $\quad 68$

Programmes of Governance $\quad 69$

Calculative Practices 72

Power relations $\quad 74$

Dimensions of East African Communications Transformations 76

\section{Chapter Two}

The Neoliberalization of East African Mediascapes $\quad 80$

Preferred Practices in Broadcasting Reform $\quad 86$

Performance Benchmarking of Telecommunications Reform 89

Monopolizing Practices of Communications Firms 94

Calculative Practice of Cross-Media Ownership 94

Calculative Practice of Acquisition 96

Networking ICT Policy-Making Processes $\quad 99$

The African Information Society Initiative 99

ICT Policy-Making Processes in East Africa 101

Networking and Knowledge Production 106

Networking and Neoliberal Global Governance 108

"Neoliberalizing" East African Communications Transformations 110 


\section{Chapter Three}

\section{Epistemic Genealogy,}

Global Governmentality, and Critical Frame Analysis

Document Research and Frame Analysis 116

$\begin{array}{ll}\text { Navigating through Frame Analysis } & 119\end{array}$

$\begin{array}{ll}\text { Positivist Frame Analysis } & 120\end{array}$

Interpretive Frame Analysis 123

Critical Frame Analysis 126

Interpreting Data from a Critical Frame Perspective 133

A Gramscian Epistemology 133

A Foucauldian Epistemology 135

Critical Frame Analysis and Global Governmentality Perspective 138

\section{Chapter Four}

An Epistemic Genealogy of

East African Communications Transformations 142

Sampling Procedure 143

Problematization of Planned Economy 148

From Plan to Market 149

From Planning to Effective State 150

From Public to Market-Supporting Institutions 152

Problematization of the Investment Climate 153

Diagnostic Framing 153

Prognostic Framing 154

Motivational Framing 155

Problematization of the Digital Divide 156

Diagnostic Framing: The Widening Digital Divide 156

Prognostic Framing: The Private Provision of ICT Services 158

Motivational Framing: ICTs Enhance Economic Development 161

Framing East African ICT Policies 163

The Framing Scope 163

Good Policy Practices 164 
Oppositional Framing: The Threat to Cultural Sovereignty

A Critical Fame Perspective of Findings

Hegemonic Framing

National-Popular Rationality / Ideology

The Power / Knowledge Thesis

The Automatic Functioning of Power

Governing the Epistemic Foundations

\section{Chapter Five}

\section{An Epistemic Genealogy of ICT News in Kenya}

Procedure for Data Collection

Duration of the Study

East African Newspapers and Neoliberal World Order

Reporting Activities of ICT Civil Society Organizations

The Problematization of Economic Globalization

Diagnostic Framing

Motivational Framing

Prognostic Framing

The President's Framing of Kenya's ICT Strategy

Enabling Private Investment

Enhance ICT Skills and Use

Develop ICT Infrastructure

The Daily Nation's Framing of ICT Issues

News Extensions from the Draft ICT Bill 204

News Extensions on the Universal Access Fund 208

News Extensions on Market Liberalization $\quad 210$

Discussion of Findings 213

Lack of Prominence of ICT Civil Society Organizations 213

Doing Ideological Work 216

Hegemonic Media Frames 222

No Immanent Critique $\quad 226$ 
Unexpected Support

The Permeation of Global Neoliberalism

\section{Conclusion}

Bringing It All Back Home 231

Expansion of the Democratization Process 234

Reforming Communication Education 244

Diversifying Research on African Communications Transformations 247

Re-conceptualizing Global Governance 249

Adopting an Epistemic Genealogical Perspective 251

Demarcation of Critical Frame Analysis 252

Final Remarks 253

$\begin{array}{ll}\text { References } & 255\end{array}$ 


\section{Figures}

Figure 4.1 World Bank's Conception of Infrastructure Services 159

$\begin{array}{lll}\text { Figure 5.1 Framing ICT Strategy for Kenya } & 192\end{array}$

Figure 5.2 The President's Framing of ICT Strategy 201

Figure 5.3 News Extensions from the ICT Bill 205

Figure 5.4 News Extensions on Market Liberalization 211

Figure 5.5 News Extensions on ICT Skills and Use 215

Figure 5.6 News Extensions on Telkom Privatization 217

Figure 5.7 News Extensions on ICT Infrastructure Development 224

Figure 5.8 News Extensions on ICT Technological Adoption 225

\section{Tables}

Table 1.1 Deepening of Indebtedness in Sub-Saharan Africa (1970-1994) 62

Table 4.1 World Development Reports (1990-2006) 145

$\begin{array}{lll}\text { Table } 4.2 & \text { Units of Analysis } & 148\end{array}$

Table 5.1 Distribution of Articles on ICT Issues (Jan 1-Dec 31, 2006) 184

Table 5.2 ICT Strategy for Kenya-Framing Foci and Task Groups 200 


\section{Acknowledgements}

While working on this dissertation, I encountered theoretical, methodological, practical and financial challenges. Without generous support from others, it would have been impossible to complete the present study. I thank my supervisor, Professor Karim Karim, for his guidance, encouragement and accessibility throughout this academic journey. I am grateful to members of the Thesis Committee, Professors Kirsten Kozolanka and Joshua Greenberg, for their insights on various issues. I extend my thanks to the external examiner, Professor Leslie Regan Shade of Concordia University, and the internal examiner, Professor Chris Brown of the Department of Political Science, Carleton University.

I need to thank officeholders of the School of Journalism and Communication for financial support through teaching and research assignments as well as bursaries. I give special thanks to the current director, Professor Karim Karim, and Professors Ross Eaman and Paul Attallah—especially during their time as supervisor of graduate studies and associate director, respectively.

I take this opportunity to thank Professor Dwayne Winseck for being my supervisor twice-when preparing for the second comprehensive examination and during the early phase of this dissertation. I thank him, too, for introducing me to the critical paradigm of communication studies which underpins my thinking about communications transformations and international communication. 


\section{INTRODUCTION}

\section{MAPPING THE DISSERTATION}

New times require new thinking. (Sinclair, 1996, p. 5)

To think and talk about the world differently is to begin to change it. (Hackett \& Zhao, 1996, p. 58)

Sub-Saharan Africa is living in new times. It is a time when previous nationalist ideologies of African socialism are being swept away by the global ideology of neoliberalism. It is a time when multi-party politics are gaining ground after decades of single-party authoritarian presidency. And it is a time of relative media freedom compared to the 1960s, '70s and '80s when journalists were murdered, detained without trial, imprisoned and intimidated.

Times have changed radically in the communications sector of sub-Saharan Africa. Prior to the 1990s, broadcasting was government business. Since then, the broadcasting sector has undergone a major transition from state to private ownership, thereby pushing governments to open the airwaves to private investors. For example, Kenya had three state-owned radio stations and one television station in 1989 , but ten years later it had 79 radio and 39 television stations. Tanzania and Uganda ended the 1980s with a single station for radio and television, but by the close of the 1990s, the number had risen to 14 radio and 10 television stations in Tanzania, and 37 radio and 4 television stations in Uganda. In addition to these changes are the emergence of national and regional media and telecommunications giants, increased telephone and Internet access, legal and policy reforms, and the proliferation of university programs in journalism and communication. 
The internal dynamics of political democratization since the 1990s have played a major role in these changes in the sub-Saharan African communications sector, and are the main focus of studies on this region's communications transformations. The present dissertation argues that the global dynamics of change need to be accounted for in the study of East African communications transformations. It takes as its entry point the phenomenon of economic globalization—herein referred to as a conglomeration of the global dynamics of power, knowledge and practices. This dissertation, therefore, seeks to investigate how international development organizations use the power resource of neoliberal global governance, the knowledge-form of global neoliberalism, and the practices of neoliberalization to transform East African mediascapes. ${ }^{1}$

The objectives of this study are four-fold: to conceptualize the power relations between international development organizations and East African governments, with specific reference to communications transformations (chapter one); to show how international development organizations utilize practices of neoliberalization to bring about changes in East African mediascapes (chapter two); to discuss methodological issues pertaining to the study of global neoliberalism within the context of international development organizations and East African mediascapes (chapter three); and to determine whether global neoliberalism is the knowledge-form underpinning East African communications transformations (chapter four) and news reporting on East African mediascapes—using Kenya as a case study (chapter five).

\footnotetext{
${ }^{1}$ These three fundamental concepts - neoliberal global governance, global neoliberalism and neoliberalization - are related to the agenda of economic globalization promoted by international development organizations, and are defined later in this chapter.
} 
The dissertation contributes to knowledge in three main domains: the practical in its concern with the expansion of the democratization process and the reforming of communication education in East Africa; the theoretical in terms of the diversification of research on communications transformations and the re-conceptualization of global governance; and the methodological in proposing an epistemic genealogical perspective and the reconstruction of critical frame analysis. These contributions are discussed in the concluding chapter.

This dissertation is about creating change. Specifically, it highlights ways in which international development organizations are creating change in East African mediascapes. However, it notes that the emerging East African mediascapes fall short of the democratic values of equity, participation and self-governance. The dissertation proposes that civil society organizations can counter the prevailing trend by creating emancipatory change in the sense of working towards a more humane and egalitarian East African mediascape. Thus, this study can be a resource for leaders and members of civil society organizations interested in communications issues in East Africa because it offers an audit of East African mediascapes that can form the basis for critiquing the current communications environment and making a case for a review of communications policies.

Robert Hackett, Robert McChesney and other media democracy scholars have been helpful in the identification of three main aspects of the mediascape audit that are relevant to this dissertation: institutional (McChesney, 1997; McChesney \& Herman, 1997; Cox, 2004), policy (McChesney, 2004, 2007; Strahm, 2005), and performance (Hackett et al., 2000; Phillips \& Project Censored, 2006). The institutional audit 
identifies emerging patterns of cross-media ownership and acquisition among communications firms (chapter two), and shows that these patterns distribute media resources to local and international investors, but fail to redistribute media resources to the general public. The policy audit finds that the framing of communications issues by the World Bank (as a case study of an international development organization) underpins East African governments' framing of communications policies (chapter four). This audit concludes that the World Bank's version of global neoliberalism is the epistemic foundation of East African communications policies. What this finding means is that East African governments have handed over epistemic self-governance to the World Bank. The performance audit monitors the reportage of news on information and communications technologies (ICTs) in East Africa's leading newspaper, the Daily Nation (chapter five). The main finding here is that in 2006 this newspaper framed ICT news in line with the framing of ICT issues by the Kenyan government and the World Bank, thus demonstrating that global neoliberalism has become the commonsense knowledge that defines public discourse on ICT issues. Civil society organizations can use this dissertation's theoretical and methodological framework to conduct further institutional, policy and performance audits of East African mediascapes. In the long run, it is anticipated that the dissertation will support civil society organizations' work in creating emancipatory change in East African mediascapes.

Besides being an audit of East African mediascapes, this dissertation is also a study of the "globalization" movement because it gives analytical weight to that movement over the "anti-globalization" one. Studies on the latter examine the contributions of global civil society organizations, such as the World Social Forum and 
the Zapatista movement, to the work of resistance against economic globalization. My motivation for concentrating on the globalization movement, whose members include the World Bank, the World Economic Forum and the World Trade Organization, is that understanding it can facilitate more focused anti-globalization commentaries. This strategy is analogous to getting into the mind of the enemy before going to battle. The present study offers civil society organizations information about the globalization movement as it relates to East African communications transformations.

This chapter deals with the following issues. First, it provides definitions of key concepts in this dissertation. Secondly, it reviews literature on African communications transformations and assesses the application of available perspectives to the study of changes in East African mediascapes. Thirdly, it argues that the theoretical roots of studies on African communications transformations are grounded in the liberal theory of communications transformations, but finds this theory lacking theoretical sophistication to facilitate the conceptualization of East African communications transformations in relation to international development organizations.

Fourthly, the chapter discusses East African communications transformations as a slice of the political-economic changes occurring in East Africa. These changes can be attributed to specific global dynamics of change-neolibeal global governance, global neoliberalism and neoliberalization—which this chapter argues are captured in the concept of economic globalization. The chapter attempts to conceptualize economic globalization from the Foucauldian global governmentality perspective with the aim of showing how global dynamics of change have contributed to on-going political-economic changes in East African mediascapes. Fifthly, the chapter offers a snapshot of the 
findings of this dissertation in the form of three sets of "democratic deficits" embedded in the global dynamics of neoliberal global governance, global neoliberalism and neoliberalization: loss of epistemic self-governance, inadequate redistribution of media resources, and deficient participation of citizens. The section also revisits solutions to the democratic deficits that the concluding chapter proposes. Finally, this chapter closes with an outline of the dissertation that highlights the salient issues in each chapter.

\section{Definition of Key Concepts}

Thus far, I have mentioned the following concepts as fundamental to this dissertation: economic globalization, global neoliberalism, neoliberal global governance, neoliberalization, international development organizations, East Africa, mediascapes, and communications transformations. The following paragraphs explain how these concepts are used in this dissertation.

Economic Globalization: This dissertation conceptualizes economic globalization as a human creation, a spatial phenomenon and a networking project. Economic globalization does not drive itself; its driving force is human agency (Steger, 2002). It is not spaceless; it is spatial in the sense that it has sites of origin, expansion and contestation (Tickell \& Peck, 2003). It is not an abstract force, as the World Bank claims (2002b), but a networking project (e.g., the African Information Society Initiative set up by international development organizations). These definitional characterizations of economic globalization are discussed later in this chapter in relation to East African mediascapes and the global dynamics of neoliberal governance, neoliberalism and neoliberalization. 
Global Neoliberalism: This term refers to the rationality or ideology that promotes market economy, economic globalization and liberal democracy. This rationality privileges private over public ownership of property, market and trade liberalization over planned markets, and privatization over nationalization (of telecommunications, electricity and transportation, among other sectors). In East Africa it informs communications policies, which mainly benefit local and international investors.

Neoliberal Global Governance: This dissertation conceptualizes "neoliberal global governance" from etymological and governmentality perspectives. From an etymological viewpoint, "governance" denotes steering, directing and controlling people and things (see for example, Skeat, 1911; Room, 2002). The adjective "global" indicates a worldwide governance situation that is created through two main strategies: interstate rules-multilateral agreements and international law; and knowledge—collection and analysis of data from nation-states, production of knowledge-forms on such themes as trade, globalization and economic development, and the application of knowledge-forms through specific practices. This dissertation focuses on the epistemic aspect of global governance-specifically, the neoliberal roots of knowledge-forms promoted through global governance-and refers to the intertwinement of global neoliberalism with global governance as neoliberal global governance. In characterizing this concept in this way, the dissertation seeks to capture the power relations between the neoliberal governors (international development organizations) and the governed (East African governments) within the issue-area of communications transformations. From a Foucauldian global 
governmentality perspective, neoliberal global governance is a power resource that international development organizations tap into with the aim of bringing about changes in East African mediascapes through the practices of neoliberalization.

Neoliberalization: Neoliberalization denotes certain practices of international development organizations through which they transform Africa into a more neoliberal region that adheres to the tenets of market economy, economic globalization and liberal democracy. I emphasize neoliberalization, not as a process or trend, but as a cluster of practices, in order to underscore the centrality of the institutional activities of international development organizations in the changes that have occurred in East African mediascapes since the 1990s.

International Development Organizations: This term refers to those international institutional bodies that were formed through multilateral agreements and are now involved in transforming Africa into a neoliberal continent. Examples of such organizations include the World Bank, the International Monetary Fund, and the United Nations Economic Commission for Africa. This dissertation examines the African Information Society Initiative as one of the main projects of international development organizations implicated in East African communications transformations.

East Africa: According to the United Nations (2006), the East African region includes the countries of Burundi, Djibouti, Ethiopia, Eritrea, Kenya, Rwanda, Somalia, Sudan, Tanzania, and Uganda. This dissertation focuses on Kenya, Tanzania and Uganda as case 
studies of communications transformations in East Africa and sub-Saharan Africa in general. Their previous and current partnership arrangements warrant studying Kenya, Tanzania and Uganda together. Unlike other countries in the region, these three have a history of close to eighty years of economic and social integration, as shown in part by the following cooperative efforts: Customs Union-Kenya and Uganda, 1917-27; Customs Union-Kenya, Uganda and Tanganyika (now Tanzania), 1927-47; East African High Commission, 1947-61; East African Common Services Organization, 196167; East African Community, 1967-77; East African Co-operation, 1993-99; and East African Community, 1999 to date (East African Community, 2007).

Mediascape: ${ }^{2}$ In discussing East African mediascapes, I view the mediascape concept as including the study of audiences (increase/decrease in readership, viewership, listening, internet use); content (expansion/contraction of media freedom and impact on information flow as well as media outlets); technologies (radio and television sets, recording machines, satellite dishes, computers); infrastructure (telephony-fixed and wireless, satellite masts, radio spectrum, cable networks, the Internet); industries (formed around content production, technologies and infrastructure, and issues of media convergence and cross-media ownership); policy and laws (national policies and legal framework, and harmonization of national and global regulations on issues of media content, communications technologies, infrastructure and industries); and communication education (institutions, programmes and teaching foci).

\footnotetext{
${ }^{2}$ The mediascape concept is the brainchild of Arjun Appadurai, who uses it to refer to conventional mass media as well as the film industry, communications infrastructure and "images of the world" produced by media (1996, p. 35).
} 
International development organizations use the concept of "information and communications technologies" (ICTs) in their documents (for example, United Nations Economic Commission for Africa, 1996; World Bank, 2002b). Viewed within the mediascape concept, ICTs refer to communications technologies and infrastructure in general, and it is this conception of ICTs that East African governments have adopted from international development organizations (chapters two and four). This dissertation narrows the mediascape concept to the study of ICT issues that pertain to communications technologies and infrastructure as well as communications industries and policies.

Communications Transformations: The dissertation characterizes changes in the aforementioned aspects of national, regional, and global mediascapes as constituting communications transformations. It analyzes communications transformations occurring in East Africa in the domains of communications technologies, infrastructure, industries and policies.

\section{Studies on African Communications Transformations}

In the early 1960s, when most African countries attained political independence from colonial powers, the emerging African politicians thought of media as tools for revolutionary change. This position was aptly argued by Kwame Nkrumah, the founding president of Ghana (1960-1966), who insisted that the concept of revolutionary media was intertwined with the thinking about African political independence as the culmination of a successful revolution against colonial powers (Ainslie, 1966, p. 19). To 
this end, the main role of revolutionary media was expected to be that of "servants of a central revolutionary purpose [that is, economic development and national unity], whose function is to explain and to inspire rather than criticize" (ibid.). The centrality of economic development and national unity in post-independent Africa paved the way for a shift in emphasis from revolutionary media to development journalism ${ }^{3}$ (Ainslie, 1966; Kunczik, 1988).

The media theory of development journalism is premised on the assumption that media should support government initiatives without engaging in the traditional watchdog role of media (McPhail, 2006, p. 40). This mode of thinking was more prevalent from the 1960 s to the 1980 s to the extent that African presidents became increasingly hostile to individuals who criticized them and their policies, and sought to silence dissent through constant arrests, torture, detentions without trial, jail terms, and even murder of individuals who dared to agitate for freedom of expression. The Index on Censorship and Article 19 issues of the 1980s provide anecdotal evidence on censorship and human rights violations of journalists working in Africa.

In the current era of political pluralism, there is a tendency in scholarship on African communications transformations to pay more attention to heroic struggles against development journalism (see for example, Asante, 1997; Eribo \& Jong-Ebot, 1997; M'Bayo, Omwumechili \& Nwanko, 2002; Zaffiro, 2002; Ocitti, 2005). The primary

\footnotetext{
${ }^{3}$ The theoretical foundations of development journalism and single-party politics in Africa can be traced to the Marxist-Leninist doctrine of democratic centralism. Allan Todd notes: "Although he [Lenin] believed that all members of the party should have a right to form factions to argue their points of view (the democratic part of democratic centralism), once a decision had been made by party members, all members should give it their full support, even if they had argued and voted against it and even if the decision had only gained a majority of one (this was the centralism aspect) (2002, p. 5)." The doctrine, therefore, required that all people and sectors in society,
} 
shortcoming of this focus is that it leads to superficial analysis or even a complete blacking out of the present transformations in African mediascapes. It is thus refreshing to note the emergence of two perspectives in the 2000s-neo-multiparty and multisectoral—which offer new ways of studying African communications transformations. I review the two perspectives and assess their utility in the study of changes in East African mediascapes within the neoliberal world context.

The neo-multiparty perspective stems from Francis P. Kasoma's Ph.D. dissertation, The Press and Multiparty Politics in Africa (2000). He observes that during the single-party era of the 1960s to the 1980s, the African press was under government control and influence, but the current multiparty dispensation has brought on board other "media playmakers," or stakeholders. In proposing his "neo-multiparty conception of the press," Kasoma argues that the "influence" of new stakeholders impacts on the content, operational policies, professional ethics, and daily practices of the African press.

Kasoma posits that the contemporary African media suffers from motley of "influences" that emanate from numerous stakeholders such as the donor community, governments, opposition parties, religious communities, community networks, and nongovernmental organizations (pp. 55-65). Influences on the African press include “directing, cajoling, daring, threatening, advising, blackmailing, suggesting, complaining, requesting, ordering, demanding, [and] asking. ..." (p. 58). Kasoma claims that the donor community, unlike other stakeholders, "dictates" what "policy and conditions under which the press, as well as other sectors should operate" (p. 59). He submits that the international community has been the leading stakeholder in the African press since question. 
the 1990s, and emphasizes that other stakeholders "influence the press in their own capacity as well as in their capacity as agents of the donor community" (ibid.).

Kasoma pioneers inclusion of the donor community among other stakeholders in the study of the African press. He conceptualizes African communications transformations in terms of the expansion and contraction of press freedom, and this leads him to postulate that the current multiparty era is characterized by influences on the press from the "donor community" and other stakeholders. This focus limits Kasoma in two main ways. First, his overwhelming interest in the print media causes him to ignore massive changes occurring in the broadcasting and telecommunications sectors as well as those in the policy and legal domains. Secondly, Kasoma does not investigate the role of the donor community in transforming the structure of East African mediascapes. This study replaces the broad concept of donor community with the more specific one of international development organizations, and shows how these organizations have shaped communications transformations in East Africa (chapter two). Furthermore, the study reveals that East African communications policies are based on the neoliberal positions of international development organizations (chapters two and four).

The other recent conception of African communications transformations-the multi-sectoral perspective — springs from the work of Goran Hyden, Michael Leslie and Folu Folarin Ogundimu in Media and Democracy in Africa (2002). This perspective explores the implications of the coupling of political democratization and media on the political, technological, economic, and cultural spheres of African society. Hyden, Leslie and Ogundimu claim that the political domain pertains to struggles for media freedom within the nexus of media-government relations, while the technological domain 
encompasses the free flow of information and efforts to develop the information superhighway. Hyden and others analyze the economic domain in terms of how private or public ownership of media enhances political advantage. Their other concern is that increased concentration of African media in urban centres can bring about the total exclusion of rural residents. The scholars argue that the cultural domain must be analyzed from the standpoint of how political democratization has facilitated the free flow of information, and consequently opened the floodgates of an international flow of programs that challenge traditional African values as well as weaken the oral circulation of information that is censored by mainstream media for political reasons.

Hyden, Leslie and Ogundimu offer a meticulous analysis of the African media in the current era of political democratization. Their studies are strong in examining how media freedom impacts on various aspects of social life, but are extremely weak in assessing the impact of the neoliberal world context on African communications transformations. As with Kasoma's neo-multiparty conception of the press, the multisectoral perspective fails to investigate how international development organizations have used the practice of neoliberalization to transform African mediascapes. Why do the two perspectives lack a conception of African communications transformations in relation to the neoliberal world context?

Both neo-multiparty and multi-sectoral perspectives are implicated in the mediagovernment paradigm of the liberal theory of communications transformations. The research foci of this paradigm are twofold: to measure media freedom (as Freedom House and the World Bank do) in order to determine its expansion or contraction within a particular nation-state; and/or to identify obstacles to the expansion of media freedom and 
propose ways of transcending them. Both research foci are expected to contribute to the creation of more liberal democratic societies in Africa. In light of the fact that neomultiparty and multi-sectoral perspectives as well as international development organizations promote the two research foci, it is imperative to review the liberal theory of communications transformations in relation to this dissertation.

\section{The Liberal Theory of Communications Transformations}

Drawing from his quarter-century of academic experience, James Curran (2002) offers a stocktaking survey of approaches to communication transformations. He traces the evolution of six "ideal types" of approaches to communications transformations: the liberal, feminist, populist, libertarian, cultural and radical perspectives. Curran takes the British society from 1700 to 2000 as his case study on communications transformations. Although the perspectives are analytically different, they are united in their conception of communications transformations within the context of the evolution of the British society into a liberal democracy. It is not surprising, then, that running through the research foci is the theme of freedom, which invites students of communications transformations to study struggles for emancipation from states, social elites and market forces as well as from the dominant ideologies of patriarchy, religion and ethnicity. In tandem with the quest for freedom is the fight for equality; for example, the feminist and libertarian perspectives promote struggles for equal treatment for women and moral minorities, respectively.

The liberal perspective focuses more on media-government relations in the issuearea of media freedom and is predicated on the conviction that media constitute an 
integral component of liberal democratic societies. Stemming from that position are three key premises of the liberal theory of communications transformations: the marketplace of ideas, democratic representation, and proprietorial authority (Curran, 1997, pp. 287-301). The premise of the marketplace of ideas promotes the view that all citizens are free to publish since they have equal access to the means of communication. This claim can be refuted through the case study of the Daily Nation of Kenya (in chapter five), which demonstrates that only social elites have access to mainstream media, and worse still, that the views of Kenya's civil society organizations on ICT issues do not see the light of day in mainstream media.

Coming directly from the marketplace premise is the representation premise, which claims that media are "elected" representatives of the people, just like parliamentarians. This principle is founded on the argument that media are subjected to daily elections through their sales and ratings, and therefore they exist because the audiences want them. If audiences withdraw their support to a medium, the ratings go down, with the resultant departure of advertisers and the subsequent folding of that medium. The upshot of the representation principle is that media establishments hold that just as parliament is a recognized institution of public representation, so are the media. The downside of this assumption is that media, like other public institutions, are subject to criticism. In fact, the sphere of media accountability extends beyond immediate audiences to the general public. The representation premise, therefore, can form the basis for launching (and revitalizing existing) media monitoring projects in East Africa with the aim of ensuring media accountability (as noted in the concluding chapter). 
And finally, the premise of proprietorial authority postulates that the owners of media have a right to manage the affairs of their businesses, including expansion without state interference. The premise is rooted in the claim that "press freedom is a property right exercised by publishers [and broadcasters] on behalf of society" (ibid., p. 287). Hence, the liberal theory of communications transformations advances the view that media owners, like other proprietors of services and goods, have a right to acquire more media outlets or dispose of what they have. The consequence of this view is the increased rate of corporate convergence in Canada, the United States and Britain, as well as in other western European countries (McPhail, 2006; McChesney \& Herman, 1997). Chapter two provides empirical evidence of the impact of the premise of proprietorial authority on East African mediascapes in the form of cross-media ownership. The premise has enabled a few rich people and corporations to own media establishments, and it militates against the redistribution of national resources, including media. This issue is revisited later in this chapter.

The liberal theory tends to give primacy to the study of the national dynamics of change in the communications sector. In particular, the organizing theme of this perspective - media freedom—focuses attention on media-government struggle, that is, the media's insistence on the expansion of media freedom against the backdrop of a government's tendency to contract it. The main shortcoming of liberal scholars of African communications transformations is that they are so preoccupied with studying the national dynamics of democratization that they overlook the global context in which media and nation-states are operating. Thus, liberal scholars have failed to capture the implications of international development organizations' project of economic 
globalization in African mediascapes. This dissertation expands the study of African communications transformations by seeking to make connections between these transformations and the economic globalization project led by international development organizations. It examines this project through the analytical lens of Michel Foucault's inspired perspective of global governmentality (chapter one) which I preview in the next section.

\section{Global Governmentality, Economic Globalization, and East African Mediascapes}

This dissertation regards communications transformations in Kenya, Tanzania and Uganda as part of the larger process of political-economic change occurring in East Africa since the 1990s. Two reasons suffice to support this claim. First, international development organizations along with national governments seek to transform East African mediascapes within the overall project of reforming East African economies. This economic rationale explains why international development organizations and national governments have emphasized: (a) restructuring of the broadcasting sector through corporatization, commercialization and market liberalization, and (b) shifting ownership of the telecommunications sector from the state to private entrepreneurs. Their main argument is that a market-oriented communications sector will contribute to the creation and enhancement of a national market-economy. This dissertation exposes the process of constructing market-oriented East African mediascapes, and in doing so, highlights the consequences of that process in terms of increased cross-media ownership and acquisitions as well as violation of the democratic values of equity and selfgovernance. 
The other reason is more political than economic: changes in national mediascapes are implicated in the neoliberal transformation of East African nation-states. A neoliberal state desists from owning means of production and interfering in products and services markets (World Bank, 1997); rather, it builds a regulatory environment that enables competition to thrive among market players (World Bank, 2005). The neoliberal thrust in national communications policies indicates that neoliberal transformations are shaping the operations of East African nation-states. Moreover, the dissertation observes that Kenya-based civil society organizations concerned with communications have yet to show tangible resistance to neoliberal transformations of East African nation-states and economies because they have yet to adopt the democratization of mediascapes as one of their issue-areas. This study provides an initial basis of knowledge for civil society groups interested in pushing for the democratization of mediascapes, that is, ensuring that communications policies and structure of mediascapes promote democratic values (McChesney \& Hackett, 2005; Hackett \& Carroll, 2006).

The political-economic nature of East African communications transformations can be examined through the lens of political economy approaches. Political economists of communication focus on assessing the extent of corporatization, commercialization, liberalization and privatization (among other related phenomena), and their implications for national, regional and global mediascapes (Mosco, 1996; McChesney \& Herman, 1997; McPhail, 2006). Indeed, I have used these political-economic categories in this dissertation, yet the dissertation does not operate within a mainstream political economy of communication perspective. Rather, it benefits from the Foucauldian post-structuralist perspective of global governmentality (within the critical wing of international political 
economy) which emphasizes the role of power, knowledge and practices in politicaleconomic changes. ${ }^{4}$ This perspective has aided in studying the global dynamics of change in relation to transformations occurring in East African mediascapes. Although the entrypoint to this study is the process of economic globalization, this dissertation refuses to conceptualize this process as a "natural" phenomenon, but looks beyond its definition as "flows" of economic factors and pays close attention instead to its epistemic dimension.

\section{Conceptualizing Economic Globalization}

Manfred Steger (2002) teaches that economic globalization is not a natural phenomenon like rain, snow, the flowing of water in rivers, ocean tides, hurricanes and earthquakes. But for the World Bank (2002b) and East African governments (Government of Kenya, 2006a, 2006b; Government of Tanzania, 2003; Government of Uganda, 2003), the natural phenomenon concept is the prevalent view. Natural phenomena are unstoppable and unavoidable, and human beings are at their mercy. What human beings have to do is adjust to natural phenomena—which is what the World Bank and East African governments expect East Africans to do in the face of economic globalization.

The natural-phenomenon world-view tends to promote the notion that East African communications transformations are natural occurrences. Within this worldview, then, the research task for students of communications transformations is two-fold: to determine the extent to which governments have harnessed economic globalization within national communications sectors; and to make proposals to governments and entrepreneurs on how national communications sectors can benefit from economic

\footnotetext{
${ }^{4}$ For the philosophical movement of post-structuralism within international political economy, see Wendy Larner (1997), Marieke de Goede (2006) and Richard Le Heron (2007).
} 
globalization. This approach neglects the study of how international development organizations are transforming East African mediascapes in the name of delivering the benefits of economic globalization. This 'how' question is the focus of this dissertation.

The other point is that the study of economic globalization involves more than presenting a descriptive account of this evolving worldwide phenomenon that is spreading across territorial borders and integrating national economies into a single world economy (Held \& McGrew, 2002b; Jones, 2006; O'Rourke, 2007). In line with this descriptive conception of economic globalization, social analysts document "flows" across borders of economic factors such as technologies (including ICTs), labour, trade and capital (Lee, 1999; World Bank, 2002b). For their part, students of communications transformations can trace "flows" of ICTs within countries, regions and the world. Their aim is to determine the extent of ICT adoption, explain why the adoption process is fast or slow in comparison to other countries or regions, and recommend ways of maintaining high adoption rates or speeding up the adoption process. This research path does not investigate the conceptions of economic globalization that underlie studies on national and global "flows" of ICTs. Rather, this dissertation gives analytical weight to the epistemic aspect of economic globalization.

The epistemic aspect foregrounds the view that globalization in general is "an explanatory scheme for understanding the contemporary world" (Jones, 2006, p. 114). Thus, the concept does more than describe the social world; it enmeshes social analysts in modes of thought that shape their research focus. In the discussion that follows, I seek to re-think the concept of economic globalization from a global governmentality 
perspective, and in the process show how this alternative conception of economic globalization has aided in studying East African communications transformations.

\section{Economic Globalization as Governmentality}

First and foremost, this dissertation conceptualizes economic globalization as a form of governmentality. Michel Foucault conceptualized "governmentality" as a power resource used by states to produce knowledge and apply it, through practices, with the aim of governing populations (1991 [1978], pp. 102-103). Following Wendy Larner and William Walters (2004c), the dissertation considers economic "globalization as governmentality"- that is, a power resource (herein, neoliberal global governance), an "interpretive grid" (embedded in global neoliberalism), and a cluster of strategic practices (constituting neoliberalization). In conceptualizing globalization this way, I seek to account for the global dynamics of neoliberal global governance, global neoliberalism and neoliberalization, which contribute to the unfolding communications transformations in East Africa. The dissertation argues that international development organizations draw from these global dynamics while restructuring East African mediascapes. Henceforth, I elaborate on how each global dynamic of change has shaped communications transformations in East Africa.

\section{Economic Globalization as Neoliberal Global Governance}

To study the influence of neoliberal global governance on East African mediascapes, I view economic globalization as a human creation, spatial phenomenon and networking project. In regarding economic globalization as a human creation, this dissertation 
underscores the role of human beings (operating within specific institutions) in creating, reproducing and safeguarding globalization. Human agents and their institutions "govern" globalization; that is, they direct, steer, shape, control and spread economic globalization. For example, technocrats working for East African governments and international development organizations are involved in entrenching economic globalization.

As a spatial phenomenon, economic globalization has its own geography. Political-economic geographers Adam Tickell and Jamie Peck postulate that economic globalization "has a geography, with its centres of discursive production (in places like Washington, DC, New York City and London), its constantly shifting frontiers of extension and mediation (such as South Africa, Eastern Europe, Japan and Latin America) and its sites of active contestation and resistance (think of Seattle, Genoa, Cuba)" (2003, p. 164). Tickell and Peck refuse to accept the notion that economic globalization is abstract and non-spatial, and instead locate it on the world map. As it relates to neoliberal global governance, globalization has "centres of discursive production" such as Washington, DC, where the World Bank is located. The institutions in these centres produce knowledge about economic globalization that shapes how economic globalization is conceptualized and contested in various sites.

This dissertation adheres to Tickell's and Peck's geography-inspired politicaleconomic analysis of economic globalization, and identifies the World Bank as one of the nodal points of economic globalization, while East Africa is its "frontiers of extension." Within this worldview, it is possible to locate the source of the global dynamic of 
economic globalization as neoliberal global governance and link it to East African communications transformations.

Finally, this dissertation conceptualizes globalization as a networking project. In making this argument I have adopted Michel Callon's (1986) translation perspective and taken the African Information Society Initiative as the case study. The Initiative is a networking project of United Nations development agencies such as the United Nations Economic Commission for Africa; the International Telecommunication Union; the United Nations Educational, Scientific, and Cultural Organization; the United Nations Conference on Trade and Development; the United Nations Industrial Development Organization; and the International Bank for Development and Reconstruction (the World Bank).

Looked at from a translation perspective, a "network" includes the crucial "moment of enrolment" during which individuals and institutions adopt common conceptions of the social world (Callon, 1986, p. 201). The "moment of enrolment" displays asymmetrical power relations in that enrollers establish a network while enrollees join a network on condition that they adhere to the enrollers' mission and membership requirements. Within the networking project of the African Information Society Initiative, international development organizations are enrollers and East African governments are enrollees.

The example of the African Information Society Initiative demonstrates the unbalanced nature of the power relations between network enrollers (international development organizations) and network enrollees (East African governments) within the issue-area of communications. This unequal power relationship gives these organizations 
an upper hand over East African governments in that they (the organizations) produce knowledge and implement it through practices. Thus, from a translation perspective, this dissertation finds that international development organizations, as promoters of economic globalization, share unequal power relations with East African governments.

Students of communications transformations using the global governmentality approach to economic globalization can translate the aforementioned premises of economic globalization as a human creation, spatial phenomenon and networking project, into two research tasks: providing a spatial-based epistemic analysis of economic globalization within particular localities where communications transformations are occurring; and showing how communications transformations are creations of specific institutions (and their agents). I have attempted to focus on these twin research tasks in this dissertation as noted in the following discussion on economic globalization as an "interpretive grid" and "neoliberalization." The former characterization elaborates on the spatial-based epistemic analysis of economic globalization and East African mediascapes, and the latter highlights how international development organizations use institutional practices to drive East African communications transformations.

\section{Economic Globalization as an "Interpretive Grid"}

The global governmentality worldview raises concerns about the entanglement of economic globalization in power relations between international development organizations and East African governments-specifically in the issue-area of communications. This worldview adopts Foucault's concept of power, which rejects the negative view of power as "repressive," that is, as a mechanism used by coercive 
agencies of state such as the armed forces, law enforcement departments and penitentiaries (1977, p. 194; 1980, pp. 109-133). Instead, Foucault focused on how institutions exercised power through the (re)production of knowledge-forms and practices. This section discusses the epistemic aspect of power, and the next deals with the performative aspect. In both cases, I seek to examine power within the context of economic globalization and East African communications transformations.

As a concept, economic globalization is an "interpretive grid," or "conceptual apparatus," that privileges a particular way of thinking about political-economic relations (Larner, 1997, p. 61). In other words, the concept of economic globalization "renders particular aspects of social and economic life 'knowable' in specific ways" (p. 32). To analyze economic globalization as an interpretive grid, I have done an epistemic genealogical study of the communications policies of the World Bank and the East African governments of Kenya, Tanzania, and Uganda. The study is based on the argument that economic globalization is a "genealogy of ways of imagining the world" in the same sense as the master-narratives of civilization, modernization and development (Larner \& Walters, 2004c, pp. 500-502). A genealogy of economic globalization shifts research in a profound way: it avoids the search for the origins of economic globalization as the World Bank (2002b) has done, and instead investigates how specific institutions identify problems, insist economic globalization is the solution, produce knowledge about economic globalization, and implement their conception of economic globalization through practices. Since an epistemic genealogical perspective is a research orientation, I have augmented it with a research method-critical frame analysis. 
In order to show how economic globalization is conceptualized within particular institutional contexts that relate to East African communications transformations, this dissertation examines the problematization of policy positions of the World Bank in comparison with those of Kenya, Tanzania and Uganda. The World Bank identifies planned economy, unfavourable investment climate and the digital divide as hindrances to the entrenchment of economic globalization in East Africa, and draws from the rationality/ideology of global neoliberalism to overcome them. Thus, it enmeshes the phenomenon of economic globalization in global neoliberalism in such a way that it is difficult to talk about the Bank's conception of economic globalization without regarding it as an "interpretive grid" for assessing the political-economic problems facing developing countries.

The epistemic genealogy (conducted in chapter four) identifies planned economy, unfavourable investment climate and the digital divide as the political-economic problems in developing countries that the World Bank seeks to solve in the name of economic globalization. To transcend these hindrances to globalization, the Bank advocates replacement of planned economy with market economy, creation of favourable investment climates and bridging of the digital divide. Underlying these solutions is the rationality of global neoliberalism, which the Bank articulates through its policy preferences of market and trade liberalization, privatization and liberal democracy. The dissertation discovers that East African governments have framed their communications policies within the World Bank's globalization frame, and that, in 2006, the leading newspaper in East Africa-the Daily Nation-reproduced the Kenyan government's framing of communications issues. The conclusion is that the World Bank has shaped the 
epistemic foundations of East African communications, and in turn, this scenario has brought about a deficiency in the democratic value of self-governance within East African mediascapes. This observation is reviewed later in this chapter.

\section{Economic Globalization as Neoliberalization}

As noted earlier, power relations produce knowledge and practices, and thus, economic globalization can be thought of as a form of power relationship that privileges global neoliberalism and promotes neoliberal practices. The Foucauldian global governmentality perspective emphasizes that institutions exercise power relations through "calculative practices" or "technologies of power" (Foucault, 1991 [1978]; see also McHoul \& Grace, 1993, p. 65). This dissertation takes economic globalization as "neoliberalization"-that is, as an assemblage of calculative practices that spread and entrench economic globalization in its epistemic form of an interpretive grid. The conception of economic globalization as neoliberalization foregrounds the need to study power relations by focusing on practices that drive economic globalization within specific localities in the world.

The dissertation seeks to show how power relations between international development organizations and East African governments have spread economic globalization in East Africa and, in effect, produced East African communications transformations. The latter occurred through the implementation of the globalizing practice of neoliberalization in the broadcasting and telecommunications sectors as well as in the policy-making domain, which in the 1990s led to a shift in the East African broadcasting sector from the practice of nationalization to that of neoliberalization. 
Within their neoliberalization project, international development organizations champion corporatization, commercialization and market liberalization as preferred practices in broadcasting reform. The organizations expanded their project to the telecommunications sector and the policy-making domain through the calculative practices of performance benchmarking and networking, respectively. Neoliberalization of the East African broadcasting sector has created a business environment in which media firms—-for example, Nation Media Group (Kenya) and Industrial Production Promotion (Tanzania)-are practising cross-media ownership. In the telecommunications sector, neoliberalization has facilitated the engagement of Celtel International (a Kuwaiti mobile-phone company) and Africa Online (a South African Internet service provider) in the practice of acquisition.

The focus on economic globalization as neoliberalization provides a wider analytical apparatus for examining East African communications transformations than the dominant liberal perspective, which dwells on researching the role of mass media in the political democratization of East Africa. This emphasis on economic globalization gives prominence to the study of political-economic changes in national mediascapes as part of the overall pattern of change occurring in East Africa. Furthermore, the neoliberalization thrust expands the focus of the analysis from what mass media are doing to promote democratization, to how mediascapes are changing. Consequently, what is happening in East Africa is more than democratization through media; it is, indeed, the neoliberalization of East African mediascapes (chapter two).

This section has made three main claims that are central to this dissertation: East African communications transformations constitute a part of the larger picture of 
political-economic change occurring in East Africa; international development organizations champion the restructuring of East African mediascapes in the name of harnessing economic globalization; and conceptualizing economic "globalization as governmentality" aids in investigating the role of power, knowledge and practices in the on-going communications transformations in East Africa. For the first claim, I recognize that international development organizations' mission of transforming East African mediascapes is only a slice of their overall political-economic project of reforming East African nation-states and economies along the lines of global neoliberalism. To narrow the focus of the dissertation, I have examined the political-economic changes happening in East African mediascapes.

To investigate the impact of the economic globalization project on East African communications transformations, I have attempted to rethink the concept of economic globalization. Thus, this section has criticized the conception of economic globalization as a natural phenomenon and argued for the expansion of the concept beyond an analysis of the flows of economic factors, and it has identified the consequences of taking the natural-phenomenon and "flows" positions in the study of communications transformations. The section has argued for a rethinking of the concept of economic globalization within the Foucauldian global governmentality perspective, which leads to the concluding claim: economic globalization is a form of governmentality.

The present section has emphasized that power relations are embedded in the conception and spread of economic globalization. It has sought to foreground power relations by arguing that economic globalization is a human creation, spatial phenomenon and networking project, and has related these assertions to the study of East African 
mediascapes. In addition, I have adopted the Foucauldian analysis of power, which claims that power produces "things"-including knowledge and practices. Thus, by using the power resource of neoliberal global governance, international development organizations produce the knowledge-form of global neoliberalism, and implement that knowledge through practices of neoliberalization. In this dissertation I espouse the foregoing modes of thought in studying East African communications transformations. The next section observes that the adoption of the international development organizations' globalization project by East African governments has contributed to an infringement of the democratic values of equity, participation and self-governance within East African mediascapes.

\section{The Democratization Process and Democratic Deficits}

International development organizations and liberal scholarship on African communications transformations promote a particular form of democratization-the liberal variant (see for example, Bourgault, 1995; World Bank, 1997, 2002d; Hyden \& Leslie, 2002; 0citti, 2005). Through liberal democratization, citizens enjoy protection of human rights, political rights (sometimes referred to as civil liberties), and civil rightsthat is, equal treatment irrespective of gender, race, ethnicity, religion, lifestyle or social status (Daniels, 1995; Sartori, 1987). Political rights enshrine voting as the only legitimate mechanism that grants parliamentarians and governments the authority to govern nation-states. Moreover, having political rights means that citizens enjoy freedom of religion, assembly and association, and of speech—both oral and written, public and private. 
Basically, liberal democratization is the process by which citizens are expected to limit their government's power through the exercise of political rights and the monitoring of respect for human and civil rights. Emerging from liberal democratization is "an attitude of mistrust toward government" (Rosenblum, 1995, p. 756) that constitutes the worldview of the liberal approach to communications transformations. This attitude is best exemplified in the liberal conception of the media as "watchdogs" over government (World Bank, 2002d). Liberal communication scholarship holds that enhancement of political democratization will create a more liberal democratic society—especially through the expansion of media freedom.

The overwhelming focus of liberal scholarship on political democratization blinds it to the importance of studying the broader process of "neoliberalization" in East Africa. The World Bank and other international development organizations unleashed neoliberalization on Africa in the 1980s through structural adjustment programmes. When African governments allowed multi-party politics in the 1990s, international development organizations incorporated liberal democratization into their projects of neoliberalization for developing countries (see for example, World Bank, 1997). Initially, the practice of neoliberalization was based on the neoliberal policies of market and trade liberalization as well as privatization of state-owned enterprises, among others (Williamson, 1990, 1997). Currently, international development organizations along with the Group of Seven (G7) states drive neoliberalization through their advocacy of market economy, economic globalization and liberal democratization.

The concluding chapter shows that international development organizations' economic globalization project has restrained expansion of democratization within East 
African mediascapes. The incorporation of democratization into the economic globalization project has brought about three main "democratic deficits" within East African mediascapes: loss of epistemic sovereignty, inadequate redistribution of media resources, and deficient participation of citizens. I highlight key aspects of these democratic deficits, and thereafter, preview ways of transcending them.

\section{Loss of Epistemic Self-governance}

Struggles for democratization in East Africa have gravitated around the promise of selfgovernance. This promise motivated East Africans to fight against colonial rule, and for over two decades after independence it became the driving force for struggles against authoritarian presidents. The point is that democratization brings about the expansion of self-governance of a nation in matters pertaining to politics, economy, culture, social relations, and even the epistemic basis of public policy.

Through epistemic self-governance, nations formulate their own knowledgeforms to guide policy-making processes. For example, after attaining political selfgovernance, or independence, East African governments engaged in epistemic selfgovernance; that is, they formulated policy documents that became the foundation for public policies. These foundational policy documents were African Socialism and Its Application in Kenya (1965), The Arusha Declaration (Tanzania, 1967), and The Common Man's Charter (Uganda, 1969). However, the shift from authoritarian presidency to multi-party politics has not been accompanied by the formulation of policy documents that enhance epistemic self-governance. This is because since the 1980s, international development organizations have been producing tailor-made neoliberal 
economic solutions for application by East African governments. As noted in chapter four, these solutions permeate East African communications policies and have become the knowledge form that is driving changes in national mediascapes. By drawing on the neoliberal positions of international development organizations, East Africans have lost their ability to govern themselves epistemically. In essence, then, international development organizations are "thinking" for East Africans instead of East Africans "thinking" for themselves. Thus, international development organizations are governing East Africans in the issue-area of the epistemic foundations of public policy. To remedy the democratic deficit engendered by the loss of epistemic self-governance, East Africans need to deliberate on the knowledge forms that best suit their needs and aspirations.

\section{Inadequate Redistribution of Media Resources}

I take the position that media are national resources--that is, citizens can use them as tools for building a better nation. As national resources, media enhance the democratization process, promote national identity and cohesion, organize people, and create jobs, among other contributions. Thus, media owners benefit from media businesses because people have entrusted them with the national resources of media. This viewpoint leads to the argument that citizens have a right to own media, and as such, national communications policies should promote the redistribution of media to as many citizens as possible.

The scenario that has emerged in East Africa since the 1990s is that there is inadequate redistribution of media resources. Indeed, available evidence (as discussed in chapter two) indicates that ownership of East African media is the preserve of a few rich 
people or large corporations. The chapter offers two examples of media giants in East Africa—Nation Media Group (Kenya) and Industrial Production Promotion (Tanzania)— that have engaged in cross-media ownership of newspapers (dailies and weeklies), magazines, and radio as well as television stations. In addition to owning major media outlets in Kenya, the leading regional media giant-Nation Media Group-also owns a daily newspaper in Tanzania and Uganda.

By highlighting the evolving concentration of media ownership, I am not criticizing media proprietors for adopting cross-media expansion as their business strategy. They have a right to do so; in fact, media proprietors are taking advantage of the situation created by East African governments through their communications policies. What this analysis underscores is that East African governments have facilitated the concentration of media ownership in a few hands, and as a result, have failed to redistribute media resources to the majority of East Africans.

Furthermore, one would expect that groups owning community broadcasting stations would, in addition to enhancing the public sphere, be permitted to reap financial benefits just as commercial broadcasters do. In banning profit-making by community broadcasting stations, East African governments are denying people their right to gain from media as a national resource. Equitable (re)distribution of national resources is a democratic right of citizens, and consequently, restricting the allocation of media resources undermines the democratic value of equity. Thus, this inadequate redistribution of media resources is one of the democratic deficits embedded in current East African communications policies. 


\section{Deficient Participation of Citizens}

I hold that the expansion of ownership of mediascapes should go hand in hand with the political participation of citizens in issues of social importance such as health, education, housing, economic development, transportation and communications. International development organizations have, through the African Information Society Initiative, entwined these issues with the larger themes of global neoliberalism and the information society. Given the wide-ranging scope of these themes, it is paramount for East Africans to publicly discuss present and alternative paths towards participation in the information society, the implications of global neoliberalism, and self-governance in relation to the efforts of international development organizations.

This dissertation has found that participation of citizens in the creation of the East African communications sector has been minimal, to say the least. Chapter two shows that the "African Information Society Initiative" is the work of international development organizations and not a project that emerged from grassroots deliberations by East Africans. Even the very process of formulating East African communications policies was dominated by business, technocratic and academic elites. To make matters worse, social elites control public discourse on communications issues in East Africa as demonstrated in the case study of the Daily Nation in chapter five. The situation is such that social elites have deprived East Africans of their right to participate in the restructuring process of national mediascapes.

\section{Beyond Democratic Deficits}

So far, I have noted that East African mediascapes suffer from deficiencies of the democratic values of equity, participation and self-governance. How can the deficiencies 
be corrected? The liberal theory of communications transformations advocates democratization through media; that is, media are tools for spreading and entrenching democratization in society. I acknowledge that democratization through media is central to the process of creating a more democratic society by arguing that civil society organizations can encourage participation of citizens in communications issues through the development of alternative media. The concluding chapter agues from a Habermasian perspective that East Africans can open the public sphere through the creation and strengthening of democratic spaces where participation can thrive. It proposes that civil society organizations in their capacity as democratic spaces can enhance participation through the establishment of alternative media that would serve as forums for discussing the information society, global neoliberalism, the digital divide, and community and cooperative media ownership, among other communications-related themes.

However, I am convinced that media can also hinder the attainment of a more democratic society (Chomsky, 1989; McChesney, 1997, 1999, 2004; McChesney \& Hackett, 2005; Hackett, 2000; Hackett \& Carroll, 2006). This position is strengthened by the discovery of the above-cited democratic deficits within current East African mediascapes.

The need for mediascapes that uphold the democratic values of equity, participation and self-governance forms the basis for calling for what Robert Hackett and William Caroll (2006) term "democratization of media." This call appeals for a review of national communications policies that are creating a flawed East African mediascape. The problem is that these policies are in operation, and that unless concerted efforts are made to review them, they will continue to transform East African mediascapes along 
neoliberal lines. In the concluding chapter, I propose two strategies that can facilitate the push for new East African communications policies: make media democratization one of the core issues of ICT civil society organizations; and abandon the neoliberal conception of civil society organizations. In recommending these strategies, this study contributes to the body of knowledge that can be utilized by ICT civil society organizations to inform people about the democratic deficits within national mediascapes, and to mobilize them against current communications policies.

\section{Overview of the Dissertation}

In examining the transformation of the East African communications sector, this introductory chapter has attempted to foreground the significance of looking beyond the liberal perspective underpinning African communication studies. In doing so, it has brought on board concerns about the global dynamics of change that are driving East African communications transformations. The chapter argues that economic globalization can be characterized as a shorthand concept for the global dynamics of power (neoliberal global governance), knowledge (global neoliberalism), and practices (of neoliberalization), which this dissertation has sought to investigate in relation to international development organizations and on-going changes in East African mediascapes. From this vantage point, I have attempted to map the dissertation as follows.

Chapter one seeks to conceptualize neoliberal global governance and argues that international development organizations use it as a power resource to produce the practices of neoliberalization and the knowledge-form of global neoliberalism. The 
second chapter presents the neoliberalization practices of international development organizations that transform East African mediascapes, while the next chapter discusses methodological issues related to the study of global neoliberalism, with specific reference to international development organizations and East African communications transformations. The methodology proposed in chapter three is used in chapter four to investigate the framing of global neoliberalism in the World Bank and East African communications policies. The next chapter applies the same methodology to determine the impact of global neoliberalism on the framing of ICT news in Kenya. The concluding chapter highlights consequences of East African governments' adoption of the economic globalization frame promoted by international development organizations. The rest of this overview develops the foregoing snapshots of each chapter.

Chapter One proposes the Foucauldian global governmentality perspective as a possible alternative to the liberal theory of communications transformations. It argues that a global governance perspective such as that of global governmentality can facilitate the study of how international development organizations use the power of neoliberal global governance to restructure East African mediascapes. The chapter assesses available approaches to the global governance theory of communication, specifically Mark Alleyne's international regimes approach (1995), and the cosmopolitan governance approach of Sean O'Siochru, Bruce Girard and Amy Mahan (2002). The main shortcoming of the two approaches is that they conceptualize "global governance" as "interstate rules", that state officials must adhere to while interacting within and outside of international organizations. This way of thinking fails to conceptualize how international development organizations are backed by the power resource of neoliberal global 
governance and how they use it to transform states, economies and communications sectors.

In order to rethink the global governance concept outside conventional perspectives of the global governance theory of communication, the chapter incorporates the etymological conception of global governance. It also regards global governance as a phenomenon with a history, and thus takes into account Martin Hewson's and Timothy Sinclair's historical focus on this phenomenon. Through appropriation of Hewson's and Sinclair's work, the chapter regards neoliberal global governance as a knowledge-based strand of the global governance phenomenon. It is this form of epistemic global governance - the neoliberal variant-that constitutes power relations between international development organizations and East African governments. In relation to sub-Saharan Africa, the chapter traces the emergence of the neoliberal world order to the huge political-economic crisis of the 1970s which contributed to the devastating and continuing debt crisis in sub-Saharan Africa. It re-examines the neoliberal policy manifesto of the Washington Consensus as well as global neoliberalism, with its tenets of market economy, economic globalization and liberal democracy.

Finally, the chapter introduces the global governmentality perspective by drawing on the works of Michel Foucault, Wendy Larner, William Walters, Nikolas Rose, Peter Miller and Mitchell Dean. It discusses the conceptual tools of the perspective- political rationality, programmes of governance, calculative practices (or technologies of governance), and power relations-and closes by proposing four dimensions of East African communications transformations: calculative, epistemic, ontological, and substantive. The ontological aspect is highlighted in this chapter while chapter two deals 
with the calculative and epistemic aspects. The rest of the dissertation focuses on the epistemic dimension of East African communications transformations.

Chapter Two opens by foregrounding two major shifts that have occurred in East Africa since the 1990s: from authoritarian presidency to liberal democracy, and from African socialism to global neoliberalism. It criticizes liberal analysts of African communications transformations for neglecting the shift to global neoliberalism and its subsequent impact on East African mediascapes. The entire chapter, then, concentrates on the neoliberal shift, and takes neoliberalization practices of international development organizations as its entry-point to discussing East African mediascapes. The chapter describes neoliberalization and East African communications transformations through the lens of the global governmentality perspective - with special reference to its Foucauldian concept of "calculative practices." This concept underpins the chapter's thrust in that it is used to discuss specific changes in East African mediascapes that are attributable to neoliberalization.

This chapter regards neoliberalization practices as "calculative practices"- that is, discrete but reinforcing activities used by international development organizations to transform East African mediascapes. Through analysis of the African Information Society Initiative, a project led by these organizations, the chapter identifies networking as the calculative practice that has guided communications policy-making processes in East Africa. Actor-network theorist Michel Callon's translation perspective is helpful in conceptualizing networking as a type of asymmetrical power relationship between network enrollers (international development organizations) and enrollees (East African governments). 
In the broadcasting sector, international development organizations have convinced East African governments to use the preferred practices of corporatization, commercialization and market liberalization; moreover, the chapter notes that the World Bank has been instrumental in reforming the East African telecommunications sector through its calculative practice of performance benchmarking. These reforms in policy, broadcasting and telecommunications have contributed to the involvement of large communications firms in the practices of acquisition (Celtel International and Africa Online) and cross-media ownership (Nation Media Group and Industrial Production Promotion). The chapter concludes by observing that international development organizations have contributed greatly to East African communications transformations through their calculative practices, and in this way have spread economic globalization with the aim of integrating East African mediascapes into the world economy.

Chapter Three presents the methodology for this dissertation by presenting the underlying ontological and epistemological assumptions of the chosen research orientation and method. It proposes an epistemic genealogical perspective (emanating from the global governmentality perspective) as a possible research orientation for this dissertation. This Foucauldian perspective draws from the work of Nikolas Rose and Peter Miller, and seeks to reconstruct how programmes of governance present a specific issue as a social problem and then offer a solution based on a particular political rationality, or conception of the social world. Given that an epistemic genealogical perspective is a research orientation, the chapter augments it with a particular document research method known as frame analysis. The problem with frame analysis is that it is not unified, and therefore not a ready-to-use research method. Through a methodological 
perspective of the social sciences espoused by Norman Blaikie, Brian Fay and Balihar Sanghera, among others, the chapter divides works on frame analysis into three strands: positivist, interpretive, and critical. Each strand is assessed and critical frame analysis emerges as the best research method for this dissertation. The method draws from Antonio Gramsci's theory of hegemony and Stuart Hall's post-Marxist conception of ideology. Todd Gitlin is its founding scholar, and Robert Hackett, Stephen Reese and Oscar Gandy, among others, are its chief proponents. Critical frame analysts interpret data through concepts or perspectives drawn from critical social analysts-specifically, for this dissertation, Antonio Gramsci and Michel Foucault. The chapter wraps up with a discussion on the compatibility of critical frame analysis with the global governmentality perspective, the dissertation's theoretical framework. The discussion benefits from the work of Alan Hunt and Trevor Purvis.

Chapter Four focuses on global neoliberalism-the epistemic aspect of economic globalization. The epistemic genealogical study presented in this chapter attempts to reconstruct the World Bank's problematization of ICT issues in relation to that of East African governments. In the problematization process, the Bank regards planned economy, the investment climate and the digital divide as social problems calling for policy reform. This chapter finds that a set of three problematizations underlies East African governments' ICT policies, and this finding leads to the conclusion that East African governments have adopted the World Bank's economic globalization frame in formulating their ICT policies.

To interpret the findings, the chapter uses Gramscian and Foucauldian epistemologies - in particular, the Gramscian concepts of "hegemonic framing" and 
"national-popular rationality" or ideology, and Foucault's power/knowledge thesis and the concept of automatic functioning of power. The chapter identifies the threat posed by neoliberalization to African cultural sovereignty and looks at East African governments' counter-framing of ICT issues against the World Bank's insistence on harnessing economic globalization. The Kenyan, Tanzanian and Ugandan governments fear the influx of foreign media content will annihilate local cultures and national media enterprises, and in response, they commit themselves to the creation of local content (Kenya), use of Kiswahili when producing local content (Tanzania), and adoption of a quota system of media content (Uganda). The general idea of the oppositional framing (of ICT issues) serves as the starting point for the next chapter.

The initial concern of Chapter Five is to determine whether civil society organizations are resisting the neoliberal world order of neoliberalization, global neoliberalism, neoliberal global governance, market economy and economic globalization. One way of doing this is by analyzing news reports on ICT issues emanating from these organizations. Thus, the chapter provides a report on ICT-related news articles from three mainstream newspapers in East Africa-the Daily Nation (Kenya), the Daily News (Tanzania) and The New Vision (Uganda). A study of these articles indicates that activities of ICT civil society organizations are inadequately covered.

An in-depth analysis of the Kenyan situation has found that specific public activities of ICT civil society organizations never saw the light of day in the Daily Nation in 2006. The chapter seeks to explain this shortcoming through an epistemic genealogical study of the newspaper, and discovers that "generative reporting" was largely 
responsible. This form of reporting involves writing news from the point of view of previous problematizations of social life. The Daily Nation, for instance, reported ICT news in 2006 within the frame of the Kenyan government's and the World Bank's problematization of ICT issues. Therefore, I conclude that the newspaper participated in the ideological work of the two institutions- that is, transforming global neoliberalism from a global- to a national-popular rationality.

The Concluding Chapter addresses the issue of generative reporting, and suggests that it can be overcome through the adoption of Karim Karim's (2003) proposal for "conscientious reporting." The other suggestion is that of reforming communication education in East Africa in order to train students in both presentational skills (news reporting and production) and representational work (news framing process, discourse formation and semiotic articulations, among others). These proposals, along with that of expanding the democratization process, are part of the practical contribution this dissertation makes. The chapter observes that international development organizations through their economic globalization project have brought about three democratic deficits in East African mediascapes: inadequate redistribution of media resources, loss of epistemic self-governance, and deficient participation of citizens. The mediascapes are deficient in terms of the democratic values of equity, participation and epistemic selfgovernance, and the chapter suggests that the situation could be ameliorated through a review of East African communications policies. It observes, however, that governments are already implementing these policies, and as such, the way forward in revisiting them is through involvement of civil society organizations in communications issues. In 
conceptualizing the democratization of mediascapes, the dissertation benefits from the work of Robert Hackett and William Carroll.

In addition to the preceding practical contributions, the dissertation also offers theoretical and methodological contributions. The chapter highlights two theoretical contributions: diversifying research on African communications transformations in order to investigate the calculative, epistemic, ontological and substantive dimensions; and application of the proposed re-conceptualization of the global governance concept and global governmentality perspectives to the study of African communications transformations. Methodological contributions are as follows: inclusion of the epistemic genealogical perspective in research on communications policies and news reports on policy issues, and demarcation of critical frame analysis as a separate strand of frame research.

The chapter provides "final remarks" by reiterating the underlying logic of this dissertation: institutions (and their agents) have engendered East African communications transformations. The dissertation identifies international development organizations and East African governments as the creators of East African mediascapes, and finds that these mediascapes are flawed in that they curtail the enhancement of the democratic values of equity, participation and self-governance. I take the position that East Africans have a right to restore these values - that they can re-create what international development organizations and East African governments have created. This dissertation analyzes East African mediascapes and highlights their democratic deficits. It concludes by suggesting ways in which the people of East Africa can overcome these deficits. 


\section{CHAPTER ONE}

\section{NEOLIBERAL GLOBAL GOVERNANCE, GLOBAL GOVERNMENTALITY, AND EAST AFRICAN COMMUNICATIONS TRANSFORMATIONS}

What does it mean to govern a ship?. . . [1] consists in that activity of establishing a relation between the sailors who are to be taken care of and the ship which is taken care of, and the cargo which is to be brought safely to port, and all those eventualities like winds, rocks, storms and so on; this is what characterizes the government of a ship. (Foucault, 1991 [1978], pp. 93-94)

Research on the transformation of communications in Africa in the 1990s and beyond documents the mushrooming of privately-owned newspapers and radio and television stations, among other developments (Bourgault, 1995; Kasoma, 1997, 2000; Ogbondah, 2002; van der Veur, 2002; Johnston, 2003.) For example, when Zambia became a multiparty state, the print media, which had previously been dominated by the stateowned Times of Zambia and Zambia Daily Mail, soon faced intense competition from several new entrants-the Weekly Post, the National Mirror, The Sun, and the Weekly Standard. As for broadcasting, by the close of the 1990s numerous privately-owned stations were operating in Africa: Ghana had licensed thirty-six companies to operate radio and television stations; Tanzanians could watch programs on eight television stations and listen to eleven radio stations; and Kenyans had access to five television and nineteen radio stations (van der Veur, 2002, pp. 93-96).

Basically, African communication scholarship is engaged in what Stuart Hall (1997) and Paul du Gay (1997) refer to as the "substantive" study of cultural revolutions. The substantive approach is "concerned with matters of empirical substance" - that is, what is observable physically or statistically and constitutes the unfolding of a major phenomenon in human history, such as the transformation of communications (du Gay, 
1997, p. 1; see also Hall, 1997, p. 208). This approach documents manifested changes in national communications sectors, and the resulting data account for the substantive dimension of communications transformations. The present dissertation insists, however, that the study of East African communications transformations is more than a mere accounting of the observable manifestations of change in national mediascapes.

The envisioned study involves examining how international development organizations use the power resource of neoliberal global governance to transform East African mediascapes. The research focus entails an examination of the power relations between East African governments and international development organizations, identification of the knowledge forms underpinning communications transformations, and extraction of the specific aspects of world capitalism that constitute an historical context of changes in East African mediascapes. To pursue this research focus, this chapter conceptualizes neoliberal global governance in relation to East African communications transformations from the global governance perspective of governmentality. This theoretical framework differs from the traditional approaches to global governance of communication, i.e., the international regime approach and the cosmopolitan governance approach. The first part of this chapter, then, provides an overview and the limitations of each approach, and explains why the general theoretical thrust of traditional theories of global governance of communication is unsuitable for this dissertation. Next, I provide an etymological, ontological and governmentality conception of global governance. The chapter concludes by delineating four dimensions of communications transformations in East Africa, which are termed epistemic, calculative, substantive, and ontological. 


\section{Assessing the Global Governance Theory of Communication}

Two basic approaches constitute the global governance theory of communication: international regime and cosmopolitan governance. The theory has its roots in international relations studies, and, accordingly, the international regime approach draws on two important texts within that discipline: Stephen Krasner's edited volume International Regimes (1983), and Robert O. Keohane's and Joseph S. Nye's Power and Dependency (1989). However, it is through Mark D. Alleyne's International Power and International Communication (1995) that the approach enters international communication studies.

The cosmopolitan governance approach can be traced back to the report of the United Nations' Commission on Global Governance, Our Global Neighbourhood (1995), and to some extent to Mihaly Simai's The Future of Global Governance (1994). It gained major impetus through two works of international relations scholars David Held and Anthony McGrew, Governing Globalization: Power, Authority, and Global Governance (editors, 2002a), and Globalization /Anti-Globalization (co-authored, 2002b); and has achieved ascendance in international communication studies through the collaborative work of Sean O'Siochru, Bruce Girard and Amy Mahan, Global Media Governance: A Beginners Guide (2002). The following discussion highlights the defining features of each approach and their shortcomings in relation to the study of East African communications transformations. 


\section{The International Regime Approach}

International regime scholars operate within the purview of "international organization" but seek to analyze international regimes, that is, "sets of implicit or explicit principles, norms, rules, and decision-making procedures" formulated within a particular interstate institution (Krasner, 1983, p. 2). International organization can be defined as networks between states, interstate and non-state institutions as well as the norms that regulate behaviour among interstate and non-state actors (Keohane \& Nye, 1989, pp. 54-57). Hence, within the international regime approach, global governance is conceptualized in broad terms as "international organization," and narrowly as "international regimes" (principles, norms, rules and decision-making procedures) underpinning the operations of international institutions. It is the narrow conception of global governance as "international regime" that offers international regime scholars a research focus for analyzing the operations of international institutions.

Alleyne posits that an adequate understanding of the "structure of international communication" should incorporate regime analysis of "functional organizations" such

\footnotetext{
${ }^{5}$ Alleyne conceptualizes international institutions that handle communication issues as constituting a "structure of international communication" organized around "processes and exchanges in eight areas: telecommunications; mail; intellectual property; advertising; news; movies and TV programmes; books and periodicals; and recorded music" (1995, p. 21). He observes that telecommunications, mail services and intellectual property rights are "regimeareas" while the rest are "non-regime areas."

${ }^{6}$ Alleyne argues that international communication institutions are functional in line with the functionalist theory of international relations which states: "(1) all states have a harmony of interest that allows them to cooperate for mutual benefit; (2) political and technical matters (such as health provision, civil aviation and mails) can and should be separated in international relations [interstate interactions]; (3) there would be no recourse to war if economic and social welfare were achieved throughout international society; (4) functional organizations would have a positive spill-over influence on areas of international relations not yet covered by functional agencies" (1995, p. 22). He notes that the International Telecommunication Union and the Universal Postal Union are classic examples of the functionalist theory of international relations.
} 
as the International Telecommunication Union, the Universal Postal Union, and the World Intellectual Property Organization (1995, pp. 26-43). Using the international regime approach as the theoretical framework for this dissertation would require a regime analysis of the World Bank as a case study of an international institution involved in development and communication. This would entail identifying the principles, norms, rules and decision-making procedures that guide the Bank in allocating loans to developing countries, with a focus on seeking information on loans earmarked for telecommunication as well as information and communication technologies, among other communication-related projects; and a regime analysis of the Bank's role in enhancing the watchdog role of media in developing countries. The main shortcoming of this approach is that it would not examine the Bank's involvement in neoliberal global governance because it would pay far too much attention to the study of the "rules" surrounding interstate interactions, and the implication is that such an approach would diminish or ignore the role of knowledge in the formation of international regimes. This approach, therefore, fails to offer a way of studying neoliberal global governance and, by extension, its relation to East African communications transformations.

\section{The Cosmopolitan Governance Approach}

Cosmopolitan analysts define global governance as "a minimum framework of rules necessary to tackle global problems guaranteed by a set of institutions including both international organizations and national governments" (Centre for the Study of Global 
Governance, ${ }^{7}$ 2006). Two key points emerge from the Centre's conception of global governance. First, global governance is a set of "rules" intended to solve global problems caused by the phenomenon of globalization (Held \& McGrew, 2002a, p.1). These problems include insecurity, terrorism, environmental degradation, production of weapons of mass destruction, and global pandemics such as HIV/AIDS, and Severe Acute Respiratory Syndrome (SARS). Cosmopolitan analysts seek to identify ways and means of arresting the negative effects of globalization.

The other point is that global governance involves the interlinkage of institutions: states, international institutions, transnational corporations, global civil society, business interest organizations (such as the International Publishing Association), professional interest organizations (such as the International Federation of Journalists), and global think tanks (such as the World Economic Forum) (Hamelink, 1994, pp. xi-xiii; Messner \& Nuscheler, 2002, p. 143). To cosmopolitan governance analysts, these institutions are "authority structures" of global governance in the sense that their representatives seek to participate in "bargaining, coalition building, consensus and compromise" whenever international resolutions and laws are being formulated or revised (Held \& McGrew, 2002b, p. 67). This conception of authority structures promotes a view of global governance as being the outcome of the concerted efforts of multiple actors within the global arena.

\footnotetext{
${ }^{7}$ David Held, leading light of the cosmopolitan approach, is co-director with Mary Kaldor of the Centre for the Study of Global Governance at the London School of Economics and Political Science.
} 
O`Siochru, Girard and Mahan identify two opposing phenomena of the global governance of communication: industry governance and societal governance. The former negates cosmopolitan social democracy and promotes market economy on a global scale, while the latter adheres to a cosmopolitan worldview. ${ }^{8}$ Industry governance advances the view that the communications sector plays a part in the economy at the national and global levels, and thus, it is subject to economic policies and regulations in the same way as other sectors ( $\mathrm{O}^{\prime}$ Siochru et al., 2002, p. 5). The purpose of industry governance is to ensure fair competition among the various competitors within every sector in both national and global economies (ibid.).

Societal governance, on the other hand, starts from the premise that, unlike other sectors, the communications sector is unique because it operates within economic as well as political, social and cultural domains (ibid., pp. 6-7). As such, the media are not confined to sectoral status in the national economy since they participate "in a cultural context by renewing cultural integrity and sustaining diversity; in a social context by enhancing public understanding and education; and in a political context by constituting the sphere for open debate that is essential to a healthy democracy and as a means to express fundamental human rights including freedom of speech" (ibid.).

${ }^{8}$ David Held and Anthony McGrew (2002b) identify universal belonging, cosmopolitan right and egalitarian individualism as the key ideas underlying cosmopolitan social democracy. The principle of universal belonging advocates the view that human beings "inhabit two worlds-the local which is assigned to us by birth, and another one which is 'truly great and truly common"' (p. 309). Cosmopolitan analysts hold that the entry-point to solving global problems is a commitment to the world-view that human beings owe allegiance to universal values of humanity rather than national or sectional interests (ibid.). The principle of cosmopolitan right promotes the view that the "freedom of each person underpins the freedom of all others," and as such, cosmopolitan analysts regard participation in public debates as a human right (pp. 309-310). Finally, the principle of egalitarian individualism postulates that the enhancement of human welfare should form the basis of public policy, whether at the national or global level (p. 310). Cosmopolitan analysts argue that the public interest, not the interests of state officials or other representatives of taxonomic collectivities, should guide the formulation of public policy (ibid.). 
The cosmopolitan approach is inappropriate for use in this dissertation because it gives analytical primacy to international communication organizations. The approach involves studying a specific international communication institution with the aim of determining whether it sides with industry or a societal form of global governance, or attempts to maintain a dynamic balance between the two. Cosmopolitan analysts are, therefore, expected to recommend reforms that enhance societal governance within international communication institutions. Applying such a research focus in this dissertation would entail an evaluation of the World Bank ${ }^{9}$ in relation to the industrysocietal dialectic of global governance, making the World Bank the focal point of the dissertation and diverting attention from the study of communications transformations in East Africa. The goal of this dissertation is to investigate interactions between East African governments and international development organizations in the area of communications transformations. This thrust brings to the fore the roles of power, knowledge and calculative practices in the evolving changes within national communications sectors in East Africa.

\section{The Blind Spots of the Westphalian Approaches}

Despite their different focus, both approaches - international regime and cosmopolitan governance-share a fundamental premise: global governance is a phenomenon that

\footnotetext{
${ }^{9} \mathrm{O}$ 'Siochru, Girard and Mahan exclude the World Bank from their list of the "key institutions of media global governance": the International Telecommunication Union; the World Trade Organization; the United Nations Educational, Scientific, and Cultural Organization; the World Intellectual Property Organization; and the Internet Corporation for Assigned Names and Numbers (2002, pp. 35-116). I consider the World Bank a "key institution of media global governance"-especially, in the study of interactions between communication and economic development in the Global South.
} 
occurs when nation-states interact within international organizations and produce rules intended to guide the behaviour of state officials (Keohane \& Nye, 1989; Krasner, 1993; Held \& McGrew, 2002a, 2002b; Karns \& Mingst, 2004). Central to this premise and to the study of global governance in communication studies is the Westphalian worldview (Alleyne, 1995; O'Siochru et al., 2002). This philosophy has its roots in the Peace of Westphalia (1648), a settlement that inaugurated the modern era of interstate interactions commonly referred to as the Westphalian system. This system is based on the "principle of territorial sovereignty," according to which each state has the legal right to exist and to oversee the human affairs and natural resources within its borders, and to conduct its affairs without interference from other states (Brown, 2002, pp. 19-39; Nolan, 2002, pp. 1841-3).

The Westphalian worldview ties the global governance phenomenon to interstate relations and cooperation within various areas, including communication, and to conditions within international organizations that promote and constrain oversight over the implementation of interstate rules. The focus of this study differs from that of Westphalian global governance approaches in that it shifts emphasis from interstate rules to the study of neoliberal global governance. More specifically, the study seeks to understand how international development organizations apply the power resource of neoliberal global governance to the transformation of East African mediascapes.

Another shortcoming of the Westphalian approaches is that they take a "positive" view of global governance as a mechanism for the good of humanity, holding that the formation of international organizations and their "rules" are for the well being of all states and people throughout the world. Where international organizations have failed to 
enhance human welfare, Westphalian analysts argue that the rules of participation should be reformed to include all states and non-state actors engaged in a particular issue or area, and that economic globalization can be tamed to benefit all. International political economists Martin Hewson and Timothy Sinclair, on the other hand, argue that the global governance phenomenon is neither "necessary" nor "beneficial," and that it is neither "a political good" nor "a solvent for world's problems" (1999, p. ix). It is this view I follow in seeking to investigate the neoliberal variant of global governance in relation to communications transformations in East Africa.

\section{The Concept and Phenomenon of Neoliberal Global Governance}

The preceding discussion highlights the argument that the global governance concept and its application within communication studies is tied to its disciplinary roots in international relations studies. The rest of this chapter seeks to unbundle this concept from its traditional usage and to re-conceptualize it in such a way that it is useful in the study of communications transformations in East Africa. Through ontological and governmentality analysis, I attempt to theorize East African communications transformations within the context of the neoliberal variant of global governance. The global governance perspective of governmentality unravels another aspect of East African communications transformations that liberal theory fails to offer: it brings to the fore the argument that communications transformations are not "natural" occurrences, but rather are the work of institutions and their agents. Specifically, this perspective sheds light on the role of international development institutions such as the World Bank in the evolving communications transformations in East Africa. Moreover, the perspective 
contradicts the predominant view within the liberal theory of communications transformations that attributes changes to nation-states in their process of creating more liberal democratic societies. This study postulates that global and national dynamics complement one another in driving changes in the communication sectors of national economies.

\section{The Etymological Roots of Global Governance}

The term "governance" comes from the verb "to govern" and is derived from Old French governer (Modern French, gouverner), which describes the act of steering, directing, or controlling (Skeat, 1911; Patridge, 1961; Chantrell, 2002; Room, 2002). The adjective "global" before "governance" expresses the expansive reach of steering, directing, or controlling. The etymological roots of "governance" open an alternative way of thinking about the concept of global governance beyond its Westphalian orientation as rules applying to interstate relations. From this vantage point, I use the concept to capture ways in which international development organizations, such as the World Bank and the United Nations Economic Commission for Africa, steer, direct or control communications transformations in East Africa.

\section{The Strands of Global Governance}

Besides being a concept, global governance is also a social phenomenon. Martin Hewson (1999) identifies two strands of the global governance phenomenon—extensive and intensive. ${ }^{10}$ Extensive global governance involves the efforts of nation-states to expand

\footnotetext{
${ }^{10}$ Martin Hewson operates within a global history approach as he proposes the two strands of global governance. The fundamental argument of global historians is that "nothing is completely
} 
their authority over humanity through conquering space and time (1999, p. 98), a strategy that includes expanding physical and electronic infrastructure-for example, roads, railways, waterways, postal services, and news agencies. It was for the purpose of enhancing "extensive" global governance through communications infrastructure that the International Telegraphic Union and Universal Postal Union were launched in 1865 and 1874, respectively. Extensive global governance also involved the colonization of Africa (1880s to 1960 s) and therefore attained a coercive dimension. An example of extensive-coercive global governance in independent Africa is aid conditionality.

Intensive global governance aims at molding people's minds and behaviour through such strategies as the enactment of international laws, the formulation of multinational agreements and the production of knowledge. The creation of a national statistics centre in France in 1800, and thereafter in the United Kingdom and the United States, marked the earliest interest in knowledge production-that is, epistemic global governance $^{11}$ - which has evolved into the current phenomenon of global knowledge and information. ${ }^{12}$ Now international organizations are engaged in "informational globalism," the "practice of mobilizing information to all corners of the globe" (Hewson, 1999, p. 97), by means of collecting, analyzing, interpreting and disseminating information with

new" about globalization (Mazlish, 1993, p. 1; see also Mazlish, 1998, p. 47). To understand the current "Age of Globalization" then, global historians insist that researchers should first and foremost identify a specific manifestation of globalization and then proceed to trace its historical evolution over decades and centuries (Mazlish, 1993, pp. 1-2). Hewson argues that global governance, as with globalization, has a history that tells a story of its extensive and intensive strands.

${ }^{11}$ Epistemic global governance can be viewed as a variant of intensive global governance.

${ }^{12}$ National statistics centres of the 1800 s collected and analyzed data on such aspects as "population, mines and forges, commerce, agriculture, arts and manufacturing, and the balance of trade" (Hewson, 1999, p. 101). The main objective of these centres was to monitor the economic progress of nation-states through statistical analyses of collected data (ibid.). 
the aim of influencing thinking and behaviour ${ }^{13}$. This study examines how the World Bank and the United Nations Economic Commission for Africa use intensive-epistemic global governance in order to change East African mediascapes. These international development organizations are engaged in a particular kind of epistemic global governance - the neoliberal form-which is the subject of the following discussion.

\section{The Evolution of Neoliberal Global Governance}

Martin Hewson and Timothy Sinclair espouse an ontological perspective of global governance in that they insist that social analysts should investigate "the structure of reality and the entities that compose existing forms of global governance" (1999, p. ix). Social analysts operating within this perspective, then, are expected to perform two main tasks: to describe the world-historical context in which a particular mode of global governance emerged and evolved; and to associate that mode with the institutions that practise it. This study focuses on the neoliberal mode of global governance and seeks to investigate how the World Bank and the United Nations Economic Commission for Africa, among other international development organizations, have applied it to shape communications transformations in East Africa. To set the stage for an analysis of neoliberal global governance from a global governmentality perspective, I provide an ontological study of neoliberal global governance in relation to the world capitalist crisis of the 1970s. This mega-crisis paved the way for the emergence and evolution of neoliberal global governance through a chain of events beginning with a worldwide crisis

${ }^{13}$ Parts of this sentence are paraphrased from the Food and Agriculture Organization's Constitution of 1946, Article I.1: "The [Food and Agriculture] Organization shall collect, analyze, interpret, and disseminate information relating to nutrition, food and agriculture" (p. 84). 
in currency and energy, followed by the African debt crisis, which gave rise to the "Washington Consensus" and its neoliberal policy manifesto, which in turn led to neoliberal globalism - that is, the intertwinement of neoliberal policies with a worldview that privileges economic globalization. The following discussion highlights aspects of the spiraling effect of each factor in the world capitalist crisis of the 1970s.

The Mega-Crisis of the 1970s: This phenomenon was a conglomeration of four main crises-in currency, energy, economic growth, and food-grains (Cox, 1980). The currency crisis was occasioned by the United States when it abandoned the Bretton Woods system which made possible the conversion of national currencies against "the universal standard of value-gold" (ibid., p. 370). Without the Bretton Woods system, national currencies were to be converted against the fluctuating value of the leading currencies, mostly the United States dollar and Britain's pound sterling. The oil crisis is attributed to the decision of the Organization of Petroleum Exporting Countries (OPEC) to sharply raise the price of crude oil in 1973 and 1979. The oil price increase raised transportation costs, which spilt over into the running of government and businesses and, moreover, inflated the cost of foodstuffs and social services such as health and education. The economic growth crisis stemmed from the crises of currency and energy, which brought about exceptionally high rates of inflation in the 1970s as compared to the $1950 \mathrm{~s}$ and 1960s. Finally, the food-grain crisis was a culmination of all the other crises. Rural residents in sub-Saharan Africa suffered most as food-grain prices soared to unaffordable levels; to make matters worse, subsistence cultivation could hardly meet their basic consumption needs (Cox, 1980, pp. 370-1). 
The African Debt Crisis: As the four-pronged capitalist crisis unfolded in the 1970s, subSaharan African states sought more funding for their public expenditures. In any case, international financiers were willing to offer low rates of interest as a result of the influx of profits from oil-producing countries (Winter-Nelson, 2003, p. 132), and furthermore, sub-Saharan African states expected to pay back the loans from revenues earned through exports of primary products such as cocoa, coffee, pyrethrum and tea, among others (ibid.). Unfortunately, their hopes were dashed when "prices for Africa's export commodities dropped steadily and the volume of exports also tended to fall" (ibid.). This precipitated a situation whereby sub-Saharan African states were unable to meet debt repayment obligations, and when Mexico was unable to service its external debt in August 1982, it became apparent to the Global North that developing countries had entered an era of heavy indebtedness (World Bank, 1988, p. xi). Jill Hills aptly captures the implications of Africa's debt crisis: "For Africa, the debt crisis is a food crisis, a health crisis, an education crisis, a de-industrialization crisis, an environmental crisis, an export crisis, a crisis of sovereignty, a crisis of political influence in world affairs" (1996, p. 232). Table 1.1 (overleaf) shows the deepening of indebtedness in sub-Saharan Africa from 1970 to 1994.

The "Washington Consensus" and Neoliberalism: In 1982-83, a "consensus" emerged among the United States, the International Monetary Fund, the World Bank, and the Bank for International Settlements: debtor countries were to receive loans only on condition that they bind themselves to neoliberal policy reform (World Bank, 1988, p. xi). John Williamson refers to this meeting of minds that ushered in the infamous structural 
Table 1.1 Deepening of Indebtedness in Sub-Saharan Africa (1970-1994)

\begin{tabular}{|c|c|c|c|c|}
\hline Countries & $\begin{array}{c}1970 \\
\text { (US \$ Millions) }\end{array}$ & $\begin{array}{c}1980 \\
\text { (US\$ Millions) }\end{array}$ & $\begin{array}{c}1987 \\
\text { (US\$ Millions) }\end{array}$ & $\begin{array}{c}1994 \\
\text { (US\$ Millions) }\end{array}$ \\
\hline Cameroon & 140 & 2,513 & 4,075 & 7,275 \\
\hline Kenya & 409 & 3,383 & 5,755 & 7,273 \\
\hline Nigeria & 567 & 8,921 & 29,021 & 33,485 \\
\hline Senegal & 145 & 1,473 & 4,028 & 3,678 \\
\hline Sudan & 329 & 5,163 & 11,563 & 17,710 \\
\hline Tanzania & 188 & 2,616 & 5,788 & 7,442 \\
\hline Uganda & 152 & 702 & 1,945 & 3,473 \\
\hline $\begin{array}{l}\text { Zaire [now Democratic } \\
\text { Republic of Congo] }\end{array}$ & 311 & 4,770 & 8,758 & 12,336 \\
\hline Zambia & 654 & 3,261 & 6,623 & 6,573 \\
\hline Zimbabwe & 229 & 786 & 2,853 & 4,368 \\
\hline
\end{tabular}

Source: $\quad$ World Bank's World Debt Tables (1996) 
adjustment program as the "Washington Consensus"14 (1990, pp. 7-8). This consensus demanded that debtor countries "adjust" in accordance to ten policy prescriptions that, to a large extent, constituted a "neoliberal policy manifesto." The consensus advocated policies that sought to mesh revenue with expenditure in order to cut down on fiscal deficit; reduce public expenditure; broaden the tax base for taxable services, goods and forms of income; allow the market to determine interest rates; determine exchange rates in line with international money markets; adopt the policy of liberalization of trade (specifically, abolish protectionist policies such as import restrictions and licensing); open the economy to foreign investors; enhance property rights; implement privatization of state-owned enterprises; and adhere to the deregulation of markets (Williamson, 1990; 1997).

Through this unwritten accord, the World Bank and the International Monetary Fund as well as the United States government attained a warrant which set them on the road to transforming the economies of sub-Saharan African states according to the tenets of neoliberalism. Indeed, participants in the accord would approve loans and grants only if sub-Saharan African states showed satisfactory progress in implementing neoliberal reforms. The Washington consensus, therefore, launched a new mode of power relations in the form of a neoliberal variant of global governance.

Global Neoliberalism: Since the 1990s, the World Bank as well as other international development organizations have intensified their use of the epistemic mode of mobilizing

\footnotetext{
${ }^{14}$ John Williamson defines "Washington" as "both the political Washington of Congress and senior members of the administration and the technocratic Washington of the international financial institutions, the economic agencies of the US government, the Federal Reserve Board, and the think tanks" (1990, p. 7; emphasis added).
} 
support for neoliberal knowledge by generating media products that promote the key aspects of global neoliberalism: economic globalization; liberal democracy; and market economy, with an emphasis on market and trade liberalization and privatization.

Examples from the World Bank include the 1994 World Development Report (liberalization and privatization); Globalization, Growth and Poverty (2002b), (economic globalization); and The Right to Tell: The Role of Media in Economic Development (2002d), (liberal democracy).

Manfred Steger argues that the interweavement of economic globalization with other aspects constitutes the ideology of global neoliberalism ${ }^{15}$, and he provides five central claims of global neoliberals: 1) globalization involves the liberalization and integration of national economies into the global economy; 2) globalization is not only inevitable but also irreversible because its driving force of technological innovation is unstoppable; 3) globalization is self-driven-that is, it does not require human agency in order to flourish; 4) globalization distributes benefits to all nation-states and individuals without any discrimination; and 5) globalization promotes democracy all over the world (2002, pp. 43-80).

One of the focal points of the global neoliberal claims is that globalization is a natural phenomenon, and as such, is as unavoidable as "weather or gravity" (Steger, 2002, p. 56). The offshoot of this argument is that it seeks to "convince people that they must adapt to the discipline of the market if they are to survive and prosper" (ibid.). Thus global neoliberals maintain that globalization does not promote the interests of any social

\footnotetext{
${ }^{15}$ I use the concept of "global neoliberalism" instead of Manfred Steger's "neoliberal globalism" in order to maintain continuity with the familiar ideology of "neoliberalism," which operates within a nation-state. It is, therefore, safe to talk about the worldwide spread of neoliberalism, in tandem with economic globalization, as global neoliberalism.
} 
class or even corporate interests because anything as "natural" as globalization has no human input (ibid., p. 61). This position is contradicted by the fact that institutional agents ${ }^{16}$ and their institutions are involved in neoliberal global governance-that is, the steering, directing and controlling of economic globalization in line with neoliberal tenets. This study attempts to show how the World Bank engages in neoliberal global governance in order to expand economic globalization in East African mediascapes. In its own way, the study demonstrates that there is nothing natural about economic globalization; it is the work of agents representing institutions such as the Group of Seven, transnational corporations, and international development organizations.

This section has applied Hewson's and Sinclair's ontological approach to global governance, and through it I have offered an historical background of the neoliberal form of global governance. From an ontological perspective, the world capitalist crisis of the 1970s and the African debt crisis created a situation in which participants in the Washington consensus formulated a "neoliberal policy manifesto" that has, since the 1990s, evolved into global neoliberalism. Advocates of the Washington Consensus use the practice of neoliberalization in order to entrench economic globalization in national economies, including in the communications sector. The next section seeks to conceptualize neoliberal global governance in tandem with East African communication transformations from a global governmentality perspective.

\footnotetext{
${ }^{16}$ I use the term "institutional agents" to refer to individuals who act in the social world on behalf of their institutions. Examples of institutional agents include politicians, civil servants, firm managers, professionals, and religious leaders.
} 


\section{The Global Governmentality Perspective}

Since the 1990s, there has been an upsurge of studies around Michel Foucault's notion of "governmentality." The most notable of these works include The Foucault Effect (Burchell, Gordon \& Miller, 1991); Foucault and Political Reason (Barry, Osborne \& Rose, 1996); Powers of Freedom (Rose, 1999); Governmentality: Power and Rule in Modern Society (Dean, 1999); and Global Governmentality (Larner \& Walters, 2004a). These texts and numerous articles-for example, Larner (2000, 2002); Larner \& Walters (2004b, 2004c); and Larner \& Butler (2005)—reflect a growing interest in the study of neoliberalism as a governmentality project in the Global North, particularly in Australia, Britain, Canada, New Zealand and the United States. This trend follows the lead of Foucault, who in his sunset years (1978-1984) became increasingly engaged in studying the permeation of neoliberalism in France, the United States and the former West Germany (Gordon, 1991, p. 41).

Foucault combined two terms, "govern" and "mentality," to form the analytical concept of "governmentality" (Rose \& Miller, 1990, p. 2). At this most basic level, the concept refers to "how we think about governing"; that is, governmentality is a mode of thought that directs human beings to perform certain actions, and not others, in order to achieve set goals of managing their lives and those of others as well as the world around them (Dean, 1999, pp. 16, 209-210). Foucault cautioned that the pre-determined goals of individuals and collectivities do not necessarily advance the "common good" (1991 [1978], p. 95).

However, governmentality is more than a mode of thought; it is a practice-an "art of government," to use Foucault's phrase. Foucault traced the roots of this practice 
to ancient Hebraic and early Christian beliefs, and noted its application in eighteenthcentury Europe in relation to the governing of people and things within territorial jurisdictions (1991a, pp. 87, 93; Dean, 1999, pp. 73-97). He emphasized that, besides governing others, "one governs things"-for example, human relations, social and interorganizational networks, familial and national budgets, cultural elements (ideas, beliefs, values, norms, practices), as well as diseases, drought, famine and the like (p. 93). From this standpoint, analysts of governmentality have also included governance of time and space among the "things" that are governed (Rose, 1999; Law \& Hetherington, 1999; Larner \& Walters, 2004b, 2004c).

Wendy Larner and William Walters (2004b) observe that governmentality analysts have largely neglected "the global" because they take the nation-state as the primary unit of analysis; hence, they shift their focus from the study of "national" to "global" governmentality in order to account "for studies which problematize the constitution, and governance of spaces above, beyond, between and across states" (p. 2). This study operates within the analytic of global governmentality and seeks to account for the "global" aspect of East African communications transformations without losing sight of the national one. It takes the globalization phenomenon as representing the "global" aspect, and identifies three global dynamics of change that constitute it: power dynamics (neoliberal global governance), knowledge dynamics (global neoliberalism), and performative dynamics (neoliberalization).

As noted in the introductory chapter, the global governmentality perspective is conceptualized in terms of "globalization as governmentality," thereby giving primacy to the investigation of the power relations embedded in globalization. According to Larner 
and Walters (2004c), the perspective regards globalization as a mode of thought and acting that is securely underpinned by power relations. Foucault (1984a) argued against viewing power relations as working primarily through state institutions of repression and constitutional and legal prohibitions, holding that power relations could be conceptualized in a positive light as the capacity to produce knowledge, practices and identities. From this Foucauldian insight, I view economic globalization as promoting a type of power relationship that can be referred to as neoliberal global governance. This kind of power relationship generates a particular knowledge, the political rationality of global neoliberalism, and entrenches that knowledge in people's lives through practices of neoliberalization such as commercialization, performance benchmarking and networking (chapter two). I elaborate on this position by highlighting aspects of the key conceptual tools of governmentality studies-political rationality, programmes of governance, calculative practices (or technologies of governance) and power relationsand relate them to East African communications transformations.

\section{Political Rationality}

Political rationality is the articulation of a particular "style of thinking [that is] quintessentially concerned with the art of governing" (Gordon, 1991, p. 14). Institutional agents promote a specific political rationality in order to guide people's opinions, conduct and practices (Dean, 1999, p. 210). Foucault (1991a) argued that the particular model of political rationality that has underpinned governance strategies of individuals and populations in Europe and North America since the eighteenth century is the pastoral model, which conceives the relationship between God and the people as that of the 
shepherd and the flock, as depicted in the 23rd Psalm. Within the Christian Church, the congregation is the flock and the pastor is the shepherd in his or her capacity as God's representative. This shepherd-flock arrangement gives the shepherd the right to request personal information from individual members in order to better serve each one and the entire flock (Dean, 1999, pp. 74-76). This kind of thinking underlies various practices such as counseling, tax collection, marketing research, census taking, and data collection by international organizations.

From a Foucauldian governmentality perspective, there are numerous versions of the social world that compete with one another (Rose, 1999, p. 32). Institutional agents privilege one version of the social world over others, and proceed to construct a political rationality through concepts, themes, graphs and tables, sounds and images, and publications and conferences (ibid.). In this sense, political rationalities, in their very constitution, are "discursive constructions" in that they are formulated and promoted through programmes of governance. Thus, global neoliberalism as a political rationality is a "discursive construction" and, as such, can be studied through the analysis of related programmes of governance. With the aim of identifying specific tenets of global neoliberalism in the issue-area of ICT, I analyze ICT programmes of governance among East African governments and the World Bank in chapter four. Here I provide a conception of "programmes of governance."

\section{Programmes of Governance}

A programme of governance emerges after a process of problematization of social life. From a governmentality perspective, problematization refers to an evaluation exercise 
assessing the practicability of a political rationality, and the resultant recommendation of a specific course of action in terms of new strategies for implementing the existing political rationality or, in some cases, adopting an alternative one (Dean, 1999, p. 210). Indeed, governance involves "problematizing" social life in that politicians, journalists, activists, scholars and others question the efficacy of programmes of governance-for example, budgets, policies and legal reforms (Rose \& Miller, 1992, p. 181). In response, institutional agents such as government officials argue their case or propose new programmes of governance (ibid.). What is significant, though, is that in the postproblematization stage, institutional agents articulate a particular "regime of practices" as a possible solution to the problem at hand (Dean, 1999, p. 210).

Examples of regimes of practices include "caring" (e.g., for the young and the elderly), "curing" (the sick), and "persuading" (people to adopt new ideas and technologies) (ibid.). In the case of East African mediascapes, governments in conjunction with the private sector and international development organizations have adopted a regime of reforming sectors of the national economy, including communications, as the primary regime of practices. I take a regime of practices as an assemblage of numerous activities that overlap and reinforce one another. From this standpoint, "reforming" the East African communication sector involves, among other things, amending existing laws and enacting new ones; formulating policy documents; writing funding proposals and implementing loan agreements; evaluating the pace of change; establishing regulatory agencies; opening the market to private investors; selling state-owned enterprises; and networking within and among various entities, including 
governments, government ministries, providers of ICT services, and international development organizations.

I hold that "reforming," in its capacity as a regime of practices, underpins the restructuring of national communications sectors in East Africa and has generated programmes of governance. Here, Foucault's advice is relevant: "To analyze 'regimes of practices' means to analyze programmes of conduct. ..." (1991b, p. 75). Hence, this study examines the programmes of governance that contribute to the on-going transformation of East African mediascapes: the African Information Society Initiative (chapter two); the World Bank's funding of privatization projects and ICT policy for developing countries (chapters two and four, respectively); the ICT policies of East African governments (chapter four); and Kenya's strategy for the application of ICT in development (chapter five).

Moreover, I use Foucault's genealogical approach to the problematization of social life as an entry-point to the study of programmes of governance. In the epistemic strand of genealogical analysis, the research focus gravitates around investigating "how the different solutions to a problem have been constructed" out of prior problematizations of certain aspects of social life (Foucault, 1984b, p. 389). In line with Foucault's genealogical concern, Nikolas Rose proposes that the task of epistemic genealogists is to analyze programmes of governance with a view to retracing the process of problematization, and to identify thought patterns emanating from a problematization $(1999$, p. 58). This study is an epistemic genealogical analysis in that I seek to demonstrate that the programmes of governance involved in "reforming" East African 
mediascapes emerge from a particular set of problematizations, which lead to specific solutions.

By using an epistemic genealogical perspective, I question the "ownership" of knowledge forms contained in the ICT policies of respective East African governments, and seek to prove that the World Bank, among other international development organizations, "owns" core modes of thought underpinning communications transformations in East Africa. This exercise helps to demystify the process of East African communications transformations as a natural phenomenon of unfolding events, and advocates a view that recognizes international development organizations as key players in policy reforms and other significant on-going changes in the communications sector.

\section{Calculative Practices}

Political rationalities and programmes of governance "in and of themselves, do not constitute governance"; calculative practices, or technologies of governance, transform political rationalities and programmes of governance into specific practices (Larner, 1997, p. 33; see also, Rose \& Miller, 1990, p. 8). Calculative practices are founded on practices of calculation and inscription (Rose \& Miller, 1992, p. 185). Within governmentality studies, the notion of calculation originates from the use of statistics by governments in studying national populations, with the principal objective being to gain knowledge for designing strategies that can intensify governance (Foucault, 1991a; Elden, 2007). 
Basically, the practice of calculation involves assessment of "what should be done, in what ways, in order to achieve this or that desirable result" (Rose, 1988, p. 183). While this evaluation exercise is itself a calculative practice, it produces more calculative practices-for example, benchmarking, performance evaluation, and opinion research. Chapter two investigates the role of the calculative practices of corporatization, commercialization, market liberalization, performance benchmarking, networking, acquisition, and cross-media ownership in the evolving transformation of the East African mediascapes.

The practice of inscription helps to make the invisible visible. Through "inscription devices" such as graphs, tables, diagrams and maps, an invisible phenomenon such as a national economy is made observable and analyzable ${ }^{17}$ (Latour, 1986). Inscription devices are a result of the application of particular calculative practices, including cartography (maps), statistics (quantitative data), photography (pictures), and news reporting (news). In addition to making the invisible visible, the practice of inscription also facilitates the construction of a distinct social reality (Walters, 2002). By using and analyzing inscription devices, institutional agents (re)present and (re)produce their version of social reality in "immutable mobiles" such as press statements, reports, guidelines and policy documents. These media products are both "immutable" and "mobile"- they are in a permanent and unchangeable state and they can be transported from one place to another (Latour, 1986, pp. 20-21). Immutable mobiles

\footnotetext{
${ }^{17}$ Bruno Latour underlines the significance of the practice of inscription: "It is of course impossible to talk about the economy of a nation by looking at 'it'. The 'it' is plainly invisible, as long as cohorts of enquirers and inspectors have not filled in long questionnaires, as long as the answers have not been punched onto cards, treated by computers, analyzed in this gigantic laboratory. Only at the end can the economy be made visible inside piles of charts and lists" (1986, p. 15).
} 
are produced and distributed by institutions_- "centres of calculation"-engaged in the practice of calculation (Rose \& Miller, 1992, p. 185).

In relation to this study, I regard the United Nations Economic Commission for Africa and the World Bank as centres of calculation. In 1996, the former institution released a path-breaking immutable mobile in the issue-area of ICT: a document on the African Information Society Initiative. Since the 1990s, the World Bank has released a number of ICT-related immutable mobiles, which I analyze in chapter four in relation to those produced by East African governments. Through the practices of calculation and inscription, the World Bank constructs a particular way of thinking and talking about ICT in developing countries. Hence, I seek to determine whether that mode of thought feeds into East African policy documents and newspaper reports (chapter five).

\section{Power Relations}

So far, I have attempted to conceptualize neoliberal global governance in addition to relating analytical concepts of the governmentality perspective to the study of communications transformations in East Africa. I now address the main problematic of governmentality studies: power relations (Dean, 1999; Rose, 1999). Foucault argued that what he was struggling to understand through his research projects was power relationsnot in the negative or repressive sense, but in terms of power relations being resources for producing knowledge and practices (1984a, pp. 57-58; 1988, pp. 103-104; 1991, pp. 148149). Hence, his research question was, mainly: "How is power exercised?" (1983, p. 26). In asking the "how" question, he sought to investigate forms of knowledge and calculative practices (technologies of governance) that entrench particular power 
relations and modes of governing. The present study is guided by this Foucauldian research focus as I explore how centres of calculation-the World Bank and the United Nations Economic Commission for Africa-exercise a specific kind of power, neoliberal global governance, in their interaction with East African governments. Implicated in research on the "how" question is the need to cultivate what Foucault (1997) calls a "critical attitude" towards power relations. This involvement in social critique entails questioning the validity of laws, traditional values, and knowledge and truth claims underpinning governmentality projects ${ }^{18}$ (pp. 29-32). By developing a critical attitude, a researcher exposes governmentalization (i.e., the ways in which people are governed) to scrutiny, and contributes to the work of social movements ${ }^{19}$ that seek to inspire people "not to want to be governed like that" (pp. 29, 30). This study operates within the Foucauldian problematic of a critical attitude in that social critique is implicated in its research method of critical frame analysis. In this effort, I use insights from critical social theorists-Antonio Gramsci, Stuart Hall and, of course, Foucault—-to interpret data.

\footnotetext{
${ }^{18}$ Foucault insisted, "A critique is not a matter of saying that things are not right as they are. It is a matter of pointing out on what kinds of assumptions, what kinds of familiar, unchallenged, unconsidered modes of thought the practices that we accept rest" $(1988$, p. 154).

${ }^{19}$ There are, mainly, four types of social movements: alternative, redemptive, reformative, and revolutionary (Aberle, 1966, pp. 315-333; Marcionis \& Gerbner, 2004, pp. 594-5). Both alternative and redemptive social movements seek to change individual attitudes and behaviour while reformative and revolutionary camps focus on changing social institutions. Reformative social movements assume that the existing social order is generally acceptable and only needs modification in certain aspects, but revolutionary movements reject the current social order and offer an alternative one (Aberle, 1966, p. 317; Blumer, 1955, pp. 212-4; Cameron, 1966, p. 23; Macionis \& Gerbner, 2004, p. 595; Wilson, 1973, pp. 104-80). Those social movements that refuse forms of governmentalization fall under the reformative and revolutionary categories.
} 


\section{Dimensions of East African Communications Transformations}

This chapter has rejected the Westphalian conception of global governance within communication studies and developed instead a broad etymological definition as well as a narrow governmentality conception of this phenomenon. In general terms, the global governance concept refers to what international development organizations do in the form of steering, directing or controlling communications transformations in East Africa. In a more specific sense, a global governmentality perspective directs attention to the neoliberal strand of global governance and conceptualizes it as a power resource at the disposal of international development organizations. Through this power resource, agents of international development organizations construct and transform the rationality of global neoliberalism into the calculative practices of neoliberalization that are applicable to East African mediascapes. It is this governmentality conception of global governance that takes centre stage in this dissertation.

Operating within a global governmentality perspective, I identify epistemic and calculative dimensions of East African communications transformations. Through appropriation of the work of Stuart Hall (1997) and Paul du Gay (1997), I account for another aspect-the substantive dimension. And finally, the ontological dimension of the changes originates from Martin Hewson's and Timothy Sinclair's (1999) proposal for an ontological study of global governance. The epistemic dimension foregrounds the role of knowledge in communications transformations in East Africa. Global neoliberalism constitutes the type of political rationality underlying changes in national communications sectors. This rationality privileges knowledge forms that promote liberalization of markets and trade, privatization, economic globalization, and liberal 
democracy. International development organizations engage in neoliberalization by transforming global neoliberalism into specific practices applicable to the restructuring process of East African mediascapes. This strategy feeds into the calculative dimension of East African communications transformations in that these changes come about through the deliberate planning of activities by agents of international development organizations. The calculative dimension comprises practices that shape changes in East African mediascapes at the very basic level of everyday activities between international development organizations and East African governments.

In line with the theoretical framework of global governmentality, I postulate that epistemic and calculative dynamics have produced substantive (or observable and quantifiable) manifestations of communications transformations in East Africa. Although it is not conceptualized this way, the substantive dimension is the mainstay of studies on African communications transformations. In this study, the substantive dimension is not the primary aspect but only one among others of East African communications transformations.

Another key argument is that the epistemic, calculative and substantive dimensions operate within a particular world-historical context of changes in East African mediascapes. Studying this world-historical context unearths an ontological dimension of East African communications transformations that includes the world capitalist crisis of the 1970s, the emergence of the African debt crisis, the formulation of the Washington consensus (with its neoliberal policy manifesto), and the ascendance of global neoliberalism as a political rationality. The ontological dimension incorporates the study of world capitalism as one of the entry-points to understanding East African 
communications transformations. Consequently, this dimension brings to the fore the need to investigate interactions between economic globalization-a phenomenon of world capitalism-and on-going communications-related changes in East Africa.

Central to the four dimensions of East African communications transformations is the Foucauldian conception of power as a resource that produces specific types of knowledge and practices. In this study, I take neoliberal global governance as a particular form of power relation between international development organizations and East African governments. Through this power relation, international development organizations collect data from countries all over the world, including Kenya, Tanzania and Uganda, analyze it, and produce the knowledge form of global neoliberalism. Thereafter, they translate this knowledge, or rationality, into calculative practices applicable to national economies, including the communications sector. This study, therefore, seeks to show that international development organizations are using the power resource of neoliberal global governance to transform East African mediascapes.

From a global governmentality perspective, neoliberal global governance as a power resource has two components: power as practice (neoliberalization) and power as knowledge (global neoliberalism). The next chapter links neoliberalization to East African communications transformations through the calculative practices of international development organizations. Essentially, the chapter examines the intertwinement of the calculative and substantive dimensions of East African communications transformations. The remaining chapters of the dissertation deal with the power/knowledge aspect of neoliberal global governance: global neoliberalism. Chapter three provides the methodology for studying global neoliberalism within the context of 
East African communications transformations. Chapters four and five use that methodology to assess the extent to which global neoliberalism is the epistemic foundation of East African communications transformations and news reports on the Kenyan mediascapes. 


\section{CHAPTER TWO}

\section{THE NEOLIBERALIZATION OF EAST AFRICAN MEDIASCAPES}

It is hard to see where, either on the right or the left, this problem of power could then have been posed. On the right, it was posed only in terms of constitution, sovereignty, etc., that is, in juridical terms; on the Marxist side, it was posed only in terms of the state apparatus. The way power was exercised-concretely and in detail-with its specificity, its techniques and tactics, was something that no one attempted to ascertain. . . . (Foucault, 1984, p. 57)

The monumental shift from single- to multi-party African states in the 1990s was, indeed, a move from authoritarian presidency ${ }^{20}$ to liberal democracy. Kenya and Tanzania marked this shift through constitutional amendments in 1991 and 1993, respectively (McHenry, 2004; Kaiser \& Okumu, 2004). Considering that Tanzania had become a single-party state in July 1965 , and Kenya in June 1982, having been in de facto singleparty status since October 1969 when the late President Jomo Kenyatta banned the only opposition party, the Kenya People's Union (ibid), their move to liberal democratic government was remarkable. The Ugandan situation is different. Ugandans have gone through five coups since declaring independence in 1962: Milton Obote vs. Kabaka Mutesa II in 1966; Idi Amin vs. Milton Obote in 1971; Tanzanian forces and Ugandan exiles vs. Idi Amin in 1979; Tito Okello vs. Milton Obote in 1985; and Yoweri Museveni vs. Tito Okello in 1986 (Kaiser \& Okumu, 2004). These coups contributed to a process of "state collapse" in Uganda starting in 1966 and lasting until Museveni came to

\footnotetext{
20 I use "authoritarian presidency" to refer to regimes in Africa where a president exercises unrestricted powers in such matters as detaining persons without trial, stifling media freedom, and limiting, or seeking to eliminate, opposition (Nyong'o, 1989). Examples of authoritarian presidents include Kenyan presidents Jomo Kenyatta (1963-1978) and Daniel Arap Moi (19782002), and Tanzania's Julius Nyerere (1962-1985).
} 
power in 1986 and sought to bring about political and economic stability. ${ }^{21}$ At that time he adopted a "no-party" policy, but in 2006 Ugandans participated in their first multiparty elections.

Given their focus on political democratization, liberal theorists give primacy to the study of the implications of political changes for the African media. The following recent titles attest to this research thrust: Press and Politics in Africa (M'Bayo, Onwumechilli \& Nwanko, 2000); Media and Democracy in Africa (Hyden, Leslie \& Ogundimu, 2002); and Press Politics and Public Policy in Uganda (Ocitti, 2005). By concentrating on the political domain, liberal theorists neglect investigation of the politico-economic impact of the shift from African socialism to global neoliberalism on national communications sectors. African socialism as a political rationality was based on the ethnology of African culture, an inclination to single-party politics, the rejection of market economy, adherence to planned or mixed economies, and non-alignment in the Cold War.

In the preface to African Socialism and Its Application to Planning in Kenya (1965), President Jomo Kenyatta asserted: “We reject both western capitalism [market economy] and eastern communism [planned economy] and choose for ourselves a policy of positive non-alignment [mixed economy]" (p. i). This rationality allowed for private ownership of newspapers and magazines, and stipulated that the state was the sole provider of broadcasting and telecommunications services. Tanzanian President Julius Nyerere rejected the capitalist version of African socialism promoted by Kenyatta in

${ }^{21}$ I. William Zartman (1995) defines "state collapse" as the phenomenon in which the state fails to perform its basic functions of maintaining law and order, formulating laws and policies, enhancing national unity and identity, and sustaining physical and social infrastructure. He 
Kenya and adopted a socialist form of this rationality. His ruling party — the Tanganyika African National Union-stated succinctly in The Arusha Declaration (1967) that the means of production and communication were to be "under the control and ownership of the peasants and workers themselves through their government and their co-operatives" (p. 3). Hence, newspapers, broadcasting stations and the telecommunications sector were considered government property.

Gradually throughout the 1980s and 1990s, Kenya and Tanzania have discarded African socialism and embraced global neoliberalism. International development organizations, especially the World Bank and the International Monetary Fund, have been instrumental in this transition to global neoliberalism, mainly through structural adjustment programmes. As for Uganda, when President Yoweri Museveni took power through a coup in 1986, his National Resistance Movement released a Ten Point Programme that supported a mixed economy (National Resistance Movement, 1987). However, Museveni never implemented the Ten Point Programme; he shelved it when the World Bank, the International Monetary Fund (IMF) and other donors stepped into the Ugandan scene in 1987 (Burgess, 2004, p. 125). Uganda, like its neighbours, formulates public policies based on global neoliberalism with the aim of entrenching a market economy and harnessing economic globalization (Government of Tanzania, 2003; Government of Uganda, 2003; and Government of Kenya, 2006).

This chapter diversifies research in African communications transformations in two main ways. First, its underlying argument is that political democratization in East Africa is intertwined with the shift from African socialism to global neoliberalism, a shift state collapse starts long before people start experiencing its effects. 
in political rationality that brings on board the study of international development organizations as participants_-indeed, neoliberal global governors_-in shaping communications transformations in East Africa. These organizations draw from the power resource of neoliberal global governance, produce the knowledge-form of global neoliberalism, and use calculative practices of neoliberalization. The intent of this chapter is to show that neoliberalization has contributed to current changes in East African mediascapes.

The other fundamental argument informing this chapter is that East African communications transformations can be viewed in the context of economic globalization. In essence, economic globalization refers to the process of integrating national economies into a single world economy (Held \& McGrew, 2002a, 2002b; World Bank, 2002). In this regard, international development organizations are active in accelerating this process in East Africa through practices of neoliberalization, and given their privileged position as financial agencies and producers of expert knowledge on economic development, they have excelled in pushing for policies and laws that promote economic globalizationsuch as those that entrench the privatization of state-owned enterprises and the liberalization of trade and markets in sub-Saharan Africa. Such policy and legal reforms have played a key role in integrating national economies into a "borderless [world] economy" (Held \& McGrew, 2002a, p. 50). The "borderlessness" of this economy is further accentuated by the diffusion of information and communication technologies (ICT) as well as the integration of national ICT infrastructures into the all-encompassing global ICT infrastructure-a process that contributes to the advance of economic globalization in East Africa, including in its communications sector. The focus of this 
chapter is on performative integration, that is, how international development organizations use practices of neoliberalization to bring East African mediascapes into the communications sector of the world economy.

This chapter seeks to establish that East African communications transformations are, to some extent, a product of economic globalization. Attention is given to economic globalization and not political democratization because global dynamics of change are neglected in the study of African communications transformations (as noted in the introductory chapter). I hold that economic globalization is not a natural occurrence-that is, a phenomenon that unfolds without intervention from institutions and their agents. On the contrary, through the practices of neoliberalization, agents of international development organizations have shaped and participated in the spread of economic globalization. Furthermore, this phenomenon does not expand in a power vacuum; it is embedded in a particular form of power relations-neoliberal global governance. And as highlighted above, the knowledge-form underpinning economic globalization is that of global neoliberalism. This chapter, therefore, attempts to link economic globalization to East African communications transformations through the calculative practices of international development organizations. It observes that these organizations have promoted corporatization, commercialization and liberalization as preferred practices for use in restructuring the East African broadcasting sector; and, in addition, that the World Bank has engaged in the calculative practice of performance benchmarking of telecommunications reforms in Kenya, Tanzania and Uganda, paving the way for the dismantling of state-owned telecommunications enterprises and the resultant market liberalization of the national telecommunications sector. To enhance profit-making, 
communications firms have adopted two calculative practices: cross-media ownership (e.g., Nation Media Group and Industrial Production Promotion), and acquisition (e.g., Celtel International and Africa Online).

It may seem rather odd to refer to corporatization, commercialization, liberalization, cross-media ownership and acquisition as "calculative practices," particularly as spatialization research within the political economy perspective of communication studies conceptualizes these "calculative practices" as processes or trends (Mosco, 1996). In doing so, spatialization analysts Thomas McPhail (2006) and Robert McChesney with Edward Herman (1997) devote themselves to documenting processes and trends within the changing "global media system". ${ }^{22}$ By regarding corporatization, commercialization, liberalization, cross-media ownership and acquisition as calculative practices, I seek to emphasize that East African communications transformations are the outcome of the practice of calculation undertaken by specific institutions-in this case the World Bank, the United Nations Economic Commission for Africa, and transnational communications firms-and that this practice involves the participation of institutional agents in the decision-making processes of planning, implementation, evaluation and replication.

Finally, the chapter investigates the permeation of ICT policy-making processes in East Africa by the calculative practice of networking; studies how the African Information Society Initiative, in its capacity as a product and project of networking, has

\footnotetext{
${ }^{22}$ Spatialization research seeks to investigate "geographical and institutional extension of organizational activity" (Mosco, 1996, p. 175). Over time, this research focus has evolved into the study of emergence and evolution of global and niche-market media conglomerates which constitute a "global media system" (Herman \& McChesney, 1997, pp. 70-105; McPhail, 2006, pp. 47-174).
} 
shaped national ICT policy-making processes; conceptualizes networking with reference to national ICT policy-making processes and the African Information Society Initiative; and accounts for the impact of Y2K networking in the late 1990s on the formulation of ICT policies in East Africa.

\section{Preferred Practices in Broadcasting Reform}

Through decades of experience in the field of economic development, international organizations have accumulated a body of knowledge that prefers certain practices, which are encapsulated and advocated in their media products. A case in point is the World Bank. During the African democratization decade of the 1960s, the Bank created the "New Africa Department" with a mandate to guide the continent through a capitalist path of economic development. With the rise of neoliberalism in the 1980s through structural adjustment programmes, the Bank became more focused on prescribing particular practices to sub-Saharan African leaders (see for example, Sub-Saharan Africa: From Crisis to Sustained Growth, 1989). The preferred practices for state-owned enterprises include corporatization, commercialization, liberalization, and privatization (World Bank, 1994, 1997; see also Mustafa, Laidlaw \& Brand, 1997). Here, I seek to show that, except for privatization, these practices have contributed greatly to the on-going transformation of the East African broadcasting sector.

After independence in the 1960s and through to the 1980s, the practice in the broadcasting sector in East Africa, and in Africa generally, was nationalization. In 1964, the Kenyan government dissolved the privately-owned Kenya Broadcasting Corporation, declared it a government department, and changed its name to the Voice of Kenya 
(Roberts, 1974; Heath, 1990, 1992, 1997). In a similar move in 1965, Tanzania's parliament enacted the Tanzania Broadcasting Corporation Dissolution Act II, which assigned the right to own stations and control radio broadcasting to the state (Lederbogen, 1992, p. 48; Sturmer, 1998, p. 115). Subsequently, the government launched Radio Tanzania Dar-es-Salaam, whose main task was "to mobilize the people in the implementation of the policy of Ujamaa [socialism] and self-reliance" (Lederbogen, 1992, p. 49).

Kenya and Tanzania replaced nationalization with corporatization and commercialization of the state-owned broadcasting sector in the 1990s, and along with Uganda, they applied liberalization as another preferred practice. Through the Kenya Broadcasting Corporation Act (1989), Kenya's parliament sanctioned corporatization by transforming the Voice of Kenya into the Kenya Broadcasting Corporation, which operates as a company with legal status and obligations and has adopted the preferred practice of commercialization in order to become profitable in a sea of emerging broadcasting stations. In Tanzania, the Broadcasting Services Act (1993) declared Radio Dar-es-Salaam a corporation-thus giving legal force to corporatization and commercialization as the preferred practices in the state-owned broadcasting sector.

As for Uganda, the practices of corporatization and commercialization arrived somewhat later. In 2004, parliament enacted the Uganda Broadcasting Corporation Act, which merged Radio Uganda and Television into the Uganda Broadcasting Corporation. However, Uganda had adopted liberalization in the early 1990s along with other East African countries, and in December 1993, Museveni's government allowed two privately-owned FM radio stations to operate-Radio Sanyu and Capital One Radio 
(Ogundimu, 1996, p. 160). Since then, the government has licensed 153 radio and 31 television stations, and at present the Uganda Broadcasting Corporation operates 15 FM radio stations and 7 television channels (Uganda Communication Commission, 2007).

Kenya implemented the practice of liberalization in 1989 when it licensed the first private television station - the Kenya Television Network. The station was launched in March 1990 as a joint venture of Maxwell Communications, a British company, and the then ruling party - the Kenya African National Union (KANU), which owned $55 \%$ of the shares (Heath, 1992, p. 45). Later the government licensed several other television stations: Stellavision (1996), Citizen TV (1999), Nation TV (1999), and Family TV (1999) (Moggi \& Tessier, 2001, pp. 10-11). As of 30th September 2005, the government had granted licences to 89 television and 244 radio stations (Communication Commission of Kenya, 2007).

Tanzania accepted liberalization of the broadcasting sector in 1994 by licensing the Coastal Television Network and Independent Television. In the same year, Radio One, Radio Tumaini (Hope Radio), and Redio Sauti ya Injili (Radio Voice of the Gospel) were allowed to operate. By 31st December 2006 Tanzania had licensed 47 radio and 29 television stations (Tanzania Communications Regulatory Authority, 2007).

Since the 1990s, national broadcasting sectors in East Africa have experienced a marked increase in the number of radio and television stations and visible changes in national mediascapes. These changes can be attributed to a shift by East African governments from the practice of nationalization to the implementation of neoliberalization - a conglomeration of calculative practices including corporatization, commercialization and liberalization. 


\section{Performance Benchmarking of Telecommunications Reform}

Kenya, Tanzania and Uganda have a history of sharing telecommunications and postal services (East African Community, 1972; Hazlewood, 1975; Mazzeo, 1975). In 1933, the British colonial administration amalgamated the telecommunications and postal services of Kenya, Uganda and Tanganyika (now Tanzania). When they established the East Africa High Commission in 1947, among the services they placed under its jurisdiction were postal, telegram and telephone services as well as licensing of radio stations and receivers. In 1949, the Commission launched the East African Posts and Telegraphs Department, which in 1951 became the East African Posts and Telecommunications Administration. From 1967 to 1977, the sole provider of telecommunications services in Kenya, Tanzania and Uganda was the East African Posts and Telecommunications Corporation. After the dissolution of the East African Community in 1977, the three countries formed independent national providers of telecommunications services.

Under the direction of the World Bank and development partners in the 1990s, East African governments used the calculative practice of performance benchmarking to fast-track restructuring of telecommunications reforms. Performance benchmarking can be conceptualized generally as a process of measuring the attainment of set goals within a specified timeline (Bhatta, 2006, p. 53). In this section I evaluate the role of benchmarking practice in telecommunications reforms by re-examining loan agreements between East African governments and the International Development Association (an agency of the World Bank). The three governments received loans from the Association as follows: Uganda (Loan No. 1962 UG) of US\$11.7 million, December 2, 1988; Kenya (Loan No. $2440 \mathrm{KE}$ ) of US\$ 4.2 million, December 28, 1992); and Tanzania (Loan No. 
2486 TA) of US\$ 115.25 million, July 26, 1993. Loans to Uganda and Kenya were to fund the evaluation of selected state-owned enterprises with a view to determining the way forward for each in terms of either privatization or liquidation. Tanzania's loan was for restructuring the Tanzania Posts and Telecommunications Corporation in readiness for privatization.

Two of the performance benchmarks that Uganda was to achieve by November 30, 1994 were completion of a proposal for those state-owned enterprises that would undergo privatization, and equipping the Uganda Development Corporation with the necessary policy and legal backing for the implementation of privatization. In 1993, the Corporation received a major boost when parliament enacted the Public Enterprises Reform Statute, which authorized the privatization of state-owned enterprises (Government of Uganda, 2004). Uganda dismantled its Uganda Posts and Telecommunications Corporation in 1995 and created Uganda Telecom Limited, Uganda Post Limited, Post Bank Limited, and Uganda Communications Commission (a regulatory agency). ${ }^{23}$ In 1996, Uganda Telecom was privatized. Detecon, a German company, bought 51 percent of the shares and the government retained 49 percent (Government of Uganda, 2003, p. 16). This was in line with the Communications Act (1997), which stipulated that Uganda Telecom had to undergo privatization in order for a second national operator to be licensed (Econ One Research, 2002, p. 3). That operator was Mobile Telephone Network (of South Africa), which entered the Ugandan market of both landline and mobile telephony in 1998. Meanwhile, Celtel International was already offering services in mobile telephony after the government licensed it in July 1993 (Econ

\footnotetext{
${ }^{23}$ Uganda's parliament formalized dissolution of the Uganda Posts and Telecommunications Corporation through enactment of the Uganda Communications Act of 15th September 2000.
} 
One Research, 2002, p. 2). In 1985 Uganda had 25,580 landlines and no cell-phone subscribers (International Telecommunication Union, 2003) compared to 137,916 landlines and 3,015,493 cell-phone subscribers at the end of March 2007 (Uganda Communications Commission, 2007).

Turning to Kenya, the World Bank gave priority to the privatization of five stateowned enterprises, among them the Kenya Posts and Telecommunications Corporation. The performance benchmarks for this corporation included the writing of action plans for commercialization (business-based procedures), June 30, 1993; market liberalization of telecommunications equipment and services, December 31, 1993; and separation of the corporation into various entities, December 31, 1993. The 1996 policy framework, Economic Reforms for 1996-1998, indicates that the government incorporated the performance benchmark on separation and promised to table a bill in parliament that would pave the way for dissolution of the Kenya Posts and Telecommunications Corporation. ${ }^{24}$ That performance benchmark was realized in 1998 when Kenya's parliament enacted the Kenya Communications Act, which dismantled the corporation into five entities: Telkom Kenya Limited (telecommunications provider), the Postal Corporation of Kenya, the Communications Commission of Kenya (a regulatory agency), the National Communications Secretariat, and the Communications Appeals Tribunal (Government of Kenya, 2006). Telkom Kenya is now partially privatized and provides both landline and mobile telephone services. Safaricom Limited and Celtel International offer mobile telephone services only. Celtel International (of Kuwait) is a private company, but the government holds a sixty percent majority share in Safaricom through 
Telkom Kenya. Before the telephony industry was restructured, Kenya had 118,361 landlines (1985) and 2,279 cell-phone subscribers in 1995 (International Telecommunication Union, 2003). The Communications Commission of Kenya (2007) records 286,729 landlines and 5,729,501 cell-phone subscribers at the end of February 2006.

For the Tanzanian project, the World Bank set the basic performance benchmarks as follows: licensing one or more companies for mobile telephone services (December 31, 1993); forming a regulatory agency for the telecommunications sector (March 31, 1994); and dissolving the corporation (December 31, 1995). By 1993, Tanzania had enacted a law—the Tanzania Communications Act—that created a telecommunications regulatory agency, the Tanzania Communications Commission (now the Tanzania Communications Regulatory Authority). This law made it possible for the separation of Tanzania Posts and Telecommunications Corporation into Tanzania Telecommunications Company Limited (TTCL), and Tanzania Posts Corporation.

The privatization of TTCL occurred in February 2001 when the government sold $35 \%$ of the shares to Detecon (of Germany) and MSI Cellular Investments (now Celtel International of Kuwait). The government retained 36\%, while TTCL employees took $5 \%$, and the rest of the shares were bought by local and international banks (Tanzania Telecommunications Company Limited, 2007). In July 1999, the Government of Zanzibar established Zanzibar Telecommunications Company (Zantel), of which the Emirates Telecommunications Corporation owns $34 \%$ of the shares, and both Kinbary Investment (Channel Islands) and Meeco International (Tanzania) hold 24\% each

\footnotetext{
${ }^{24}$ The Kenyan government wrote Economic Reforms for 1996-1998 in consultation with the World Bank and International Monetary Fund.
} 
(Zanzibar Telecommunications Company, 2007). The government of Zanzibar has kept an $18 \%$ interest (ibid.).

According to the Tanzania Communications Regulatory Authority (2007), the Tanzania Telecommunications Company Limited (TTCL) operated 146,419 landlines as of March 31, 2007. The Authority also notes that on the same date, Tanzania had a total of $6,181,680$ cell-phone subscribers distributed among cell-phone companies as follows: Vodacom accounted for $51 \%$ or $3,247,921$; Celtel International, $26 \%$ or $1,676,392$; Tigo, $13 \%$ or 801,456 ; Zantel , $7 \%$ or 414,763 ; and TTCL, $3 \%$ or 1,148 .

Performance benchmarking of the East African telecommunications sector in the 1990s served a hidden agenda and, moreover, occurred without public scrutiny. It is no surprise that it is easily ignored in discussions about communications transformations in East Africa. This section gives prominence to performance benchmarking by attempting to show that the World Bank employed it with the aim of restructuring national telecommunications sectors in East Africa. As a calculative practice, performance benchmarking created a need for the legal reforms required for sanctioning the separation of state-owned telecommunications enterprises into several entities. The enactment of laws for governing national telecommunications sectors constitutes part of the picture of East African communications transformations alongside the emergence of cell-phone companies and rising cell-phone subscription. Another aspect of this transformation is the entry into the East African scene of large communications conglomerates-Detecon and Celtel International, in particular. To outdo their competitors and maintain a high margin of profit, Celtel International and Africa Online have adopted the calculative practice of acquisition. The following section discusses this calculative practice as well as that of 
cross-media ownership, and seeks to illustrate how both practices feed into East African communications transformations.

\section{Monopolizing Practices of Communications Firms}

Strategies for restructuring broadcasting and telecommunications industries as well as the formulation of market-based policies have created a high level of competition among investors in East African communications sectors. To maintain a competitive edge over rivals, wealthy investors are engaged in the monopolizing practices of cross-media ownership and acquisition. I associate the Nation Media Group and Industrial Production Promotion with the practice of cross-media ownership, and Celtel International and Africa Online with acquisition.

\section{Calculative Practice of Cross-Media Ownership}

The Nation Media Group was started in 1960 and is owned by the Aga Khan Fund for Economic Development $^{25}$ (44.73\%) and other shareholders (Nation Media Group, 2004, p. 42). Adoption of the practice of cross-media ownership by the Nation Media Group's owners can be related to their quest for maintaining dominance not only in the Kenyan mediascape, but also in the entire region of East Africa.

The Nation Media Group's main competitor in Kenya is Baraza Limited/ Standard Newspapers which owns The Standard and the Kenya Television Network. With a circulation of about 220,000 copies daily and an estimated readership of 3 million,

\footnotetext{
${ }^{25}$ The Aga Khan Fund for Economic Development is "dedicated to promoting private initiatives and building economically sound enterprises in the developing world" (Aga Khan Fund for Economic Development, 2006, p. 6). The Fund, therefore, encourages local entrepreneurs to buy shares in the Nation Media Group.
} 
the Nation Media Group's Daily Nation is far ahead of The Standard, whose 60,000 copies per day are read by about 1.2 million (World Association of Newspapers, 2003, p. 147; Nation Media Group, 2006). The Nation Media Group also owns the leading Kiswahili newspaper in Kenya, Taifa Leo ("Daily Nation") which circulates an average of 35,000 copies on weekdays and 47,000 on Sundays (Nation Media Group, 2006) and has a readership of 550,000 (World Association of Newspapers, 2003, p. 147). In 1995, the company released a weekly regional newspaper, The East African, which has a circulation of about 30,000 copies (Nation Media Group, 2006). The company is also a major shareholder in a Tanzanian daily, The Citizen, and the Daily Monitor of Uganda (ibid.).

The Nation Media Group engaged in the practice of cross-media ownership when in 2003 it entered into the East African magazine industry with the publishing of True Love and Drum (Nation Media Group, 2004, p. 13). Moreover, it owns broadcasting stations in Kenya (NTV and Nation FM radio) and Uganda (93.3K FM radio).

While the economic power of the Nation Media Group has evolved over the last forty-five years, Industrial Production Promotion (IPP Media) has been active in the Tanzanian media industry for less than fifteen years. Indeed, IPP Media was created out of and is a beneficiary of the changes in the East African communications sector that have occurred since the 1990s. During the transition period (July 1992 to December 1995) from single- to multi-party politics in Tanzania, IPP Media launched three dailies: Majira ("Time"), Nipashe ("Tell Me the News"), and The Guardian. The daily circulation figures for each newspaper as of December 31, 2002 were as follows: Majira, 23,000; Nipashe, 16,000; and The Guardian, 9,000 (World Association of Newspapers, 
2003). Some of IPP Media's rivals were strong competitors, as the daily circulation records show: Mwananchi ("Citizen"), 24,000; Daily News, 13,000; The African, 5,000; and Uhuru ("Freedom"), 3,000 (ibid.). However, IPP Media also owns a number of other dailies-the Daily Mail, Sun Set, the Financial Times, Alasiri, Kasheshe, Komesha, Lete Raha and Taifa Letu-and a weekly, The Sunday Observer (Tanzanian Electronic Networking Community, 2004; IPP Group, 2004). The World Association of Newspapers (2003) ranks IPP Media as the leading newspaper company in Tanzania.

With a view to keeping ahead of his competitors, Reginald Abraham Mengi, the proprietor of IPP Media, has embraced the practice of cross-media ownership. Mengi, a Tanzanian businessman, also owns television stations (Independent Television, East African Television, and East African News Network) as well as radio stations (Radio One, Sky FM, and East African Radio) (IPP Group, 2004). The British Broadcasting Corporation (2005) observes that Mengi "controls almost $70 \%$ of the media in Tanzania."

\section{Calculative Practice of Acquisition}

The cell-phone business is picking up in sub-Saharan Africa, and Celtel International is one of several companies establishing a foothold there. Celtel operates in Kenya, Uganda and Tanzania as well as in twelve other countries: Burkina Faso, Chad, Republic of Congo, Democratic Republic of Congo (formerly Zaire), Gabon, Madagascar, Malawi, Niger, Nigeria, Sierra Leone, Sudan, and Zambia. The company (previously known as Mobile Systems International) was the first to enter the cell-phone industry in East Africa when it opened for business in Uganda in 1995 (Econ One Research, 2002, pp. 2, 9-10). 
Proprietors of Celtel International are engaged in the calculative practice of acquisition as one of their strategies for outdoing competitors. In 2001, Celtel International entered the Tanzanian telephony market by purchasing a 35\% share in Tanzania Telecommunications Company Limited from the Government of Tanzania, which owns the other $65 \%$ (Celtel International, 2007). The company has also acquired $85 \%$ of Celtel Tanzania, while the Government retains only $15 \%$ (ibid.). Furthermore, in 2004, it paid US\$250 million for Vivendi International's $60 \%$ share of the Kenya-based Kencell, thereby establishing itself in Kenya (ibid.). (The other $40 \%$ of Kencell is owned by the Sameer Group.) Interestingly, the practice of acquisition has left its mark on Celtel International. The former proprietor, Mohamed Ibrahim, sold the company in April 2005 to Kuwait's Mobile Telecommunications Company for US\$ 3.36 billion (ibid.).

Besides Celtel International, other firms involved in the calculative practice of acquisition include Africa Online. With the rising number of computer sales and rapidly growing Internet use, provision of Internet services has become a major business area in the East African communications sector in this first decade of the twenty-first century. The following figures testify to this situation. Kenyans owned 18,000 personal computers in 1995, but in 2000 and 2003, the number had exploded to 1.5 and 3 million, respectively (International Telecommunication Union, 2005, p. 85). Only 200 people accessed the Internet from Kenya in 1995 as compared to an estimated million people in 2003 (ibid.). In Tanzania between 2000 and 2003, the number of personal computers had risen from 100,000 to 200,000, and about 250,000 people used the Internet in 2003 in contrast to only 500 in 1995 (p.150). As for Uganda, there were 10,000 personal computers in 1995; by 2000 the number had shot up to 60,000 and in 2003 it reached 
102,500 (p. 157). The estimated number of Internet users was 600 in 1995; 40,000 in 2000; and 125,000 in 2003 (ibid.).

Africa Online is the brainchild of three Kenyans-Ayisi Makatiani, Karanja Gakuo and Amolo Ng'weno-who formed the company in 1994 while studying at the Massachusetts Institute of Technology in Cambridge, Massachusetts, USA (Africa Online, 2007). The company started operating in Kenya in February 1995, and its potential attracted the attention of one of the then leading Internet service providers in the USA, Prodigy Inc. (ibid.), which bought Africa Online from its founders in November 1995. In October 1998, a consortium of African Lakes (United Kingdom) and Telcorp Communications (USA) acquired the young company, and in March 2001, African Lakes bought Telcorp's shares and became the sole proprietor of Africa Online Holdings. Since 1999, Africa Online Holdings has used the calculative practice of acquisition, and so far, it has acquired Pipex International Solution in Swaziland (June 1999), Net2000 Limited in Kenya (January 2000), UUNET Nambia (April 2000), and Swift Global Uganda (April 2000) (Africa Online, 2007). The company provides Internet services to corporate and individual customers in Kenya, Tanzania and Uganda as well as in Cote d'Ivoire, Ghana, Namibia, Swaziland, and Zimbabwe (ibid.).

Africa Online Holdings was sold by African Lakes on February 23, 2007 for 10.32 million British Pounds (about US\$20.5 million) to the current owner, Telkom South Africa (Telkom South Africa, 2007). African Lakes was dissolved in early 2007. 


\section{Networking ICT Policy-Making Processes}

A Foucauldian epistemology views "networks" as sites of power in line with Foucault's thesis: "Power relations are rooted in the system of social networks" (1983, p. 224). Foucault insisted that the entry-point to an analysis of power relations is not institutions but networks (pp. 222-224). It follows, then, that networks can be regarded as a fundamental unit of analysis, especially when investigating power relations embedded in globalization, global governance, and global economy (Dickens, Kelly, Olds \& Yeung, 2001 , p. 91). In this section, I focus on the calculative practice of networking in relation to the issue-area of ICT policy-making processes in East Africa and search for links between the mega-networking project of the African Information Society Initiative and the formulation of ICT policies in Kenya, Tanzania and Uganda.

\section{The African Information Society Initiative}

Product of Networking: The African Information Society Initiative is a product and project of networking. The Initiative emerged from networking within and outside United Nations' agencies among African ministers for national development, and among experts in information technology from the public and private sectors (United Nations Economic Commission for Africa, 2003 [1996]). Canada's International Development Research Centre in partnership with UNESCO, the International Telecommunication Union and the United Nations Economic Commission for Africa (UNECA) coordinated an African Regional Symposium on Telematics for Development in April 1995 (Amoako, 2003 [1996]). Information technologists from both public and private sectors of fifty countries attended the symposium, and its report was accepted by the UNECA Conference of 
African Ministers in May 1995 as a working document for "Building Africa's Information Highway" (UNECA, 2003 [1996]). The conference mandated a High-Level Working Group of eleven information technologists "to draft an action framework that would utilize the information and communication technologies in order to accelerate the socio-economic development of Africa and its people" (Amoako, 2003 [1996], p. iv).

Project of Networking: Following the Working Group's recommendation, the UNECA Conference of Ministers created the African Information Society Initiative in May 1996. This Initiative is a networking project in two main ways. First, the Initiative is hinged on networking between UNECA and other UN agencies—among them, the World Bank, ITU, UNESCO, the United Nations Conference on Trade and Development (UNCTAD), and the United Nations Industrial Development Organization (UNIDO) (Amoako, 2003 [1996], p. iv). Secondly, the Initiative seeks to develop a network system of ICT infrastructure and "infostructure." ICT infrastructure development involves the creation of national telephone, satellite and computer networks that link rural to urban areas, and trading centres to cities (UNECA, 2003 [1996], p. 19). It also entails connecting national ICT networks to others within the African continent, and most importantly, to the global information infrastructure (p. 20). ICT infostructure development encourages use of the Internet in gathering, analyzing, producing and disseminating information throughout the world (pp. 18-19). Internet applications include e-government, e-learning, e-commerce, e-library, website creation, and e-mail. 
Entrenching Networking: The African Information Society Initiative insists that the foremost task in developing ICT infrastructure and infostructure is that of establishing national ICT policies (UNECA, 2003). It is expected that such policies will entrench the construction of the two types of networking - infrastructure and infostructure - in national development plans and activities (UNECA, 2003 [1996]). Hence UNECA, a global-regional network, monitors the formulation of national ICT policies in Africa, as is evident in its online report of March 2007: six sub-Saharan African countries are yet to start the process of formulating an ICT policy (Eritrea, Liberia, Equatorial Guinea, Guinea-Bissau, Somalia, Sao Tome and Principe); twelve are currently engaged in ICT policy-making processes (such as Angola, Botswana, Chad, Zambia, and Zimbabwe); and thirty have an ICT policy (including Kenya, Tanzania, and Uganda).

\section{ICT Policy-Making Processes in East Africa}

The global problem of the millennium bug became a blessing in disguise to proponents of the African Information Society Initiative. Through the operations of Y2K committees, members gained first-hand experience in public-private partnerships in national and global contexts. Furthermore, the International Y2K Cooperative Centre set ICT in the limelight as it sought action at the national level in preparation for the anticipated millennium bug. As with the Initiative, the World Bank was also involved in the $\mathrm{Y} 2 \mathrm{~K}$ project. In October 1997, the Bank observed that developing countries were not giving the millennium bug the attention it deserved (International Y2K Cooperation Centre, 2000, p. 70). To ensure these countries take this issue seriously, the Bank produced a guide titled, How to Develop a National Plan for the Year 2000 Problem for Developing 
Countries (1998). The other strategy involved seeking funds for assisting developing countries to form national Y2K committees (International Y2K Cooperation Centre, 2000, p. 9). The Bank managed to get about US $\$ 40$ million from Canada, the United Kingdom and the United States among other developed countries (p. 70). Kenya, Tanzania and Uganda formed their national Y2K committees in 1998 as a joint effort involving both the public and the private sectors. This experience in public-private networking underpins ICT policy-making processes in East Africa, as the following accounts demonstrate.

Kenya: Kenya had a total of 8,000 personal computers in 1990 , and five years later the number had risen to 18,000 (International Telecommunication Union, 2003). In order to guide diffusion of this new information technology, the Ministry of Research, Technical Training and Technology (in conjunction with UNESCO) sought to formulate a "National Informatics Policy" in 1993 (Ochuodho \& Matunga, 2005). Turf wars between this Ministry and others (especially, finance, and transport and communications) worked against approval of the draft policy by the cabinet. It took another five years for ICT issues to resurface. Due to international mobilization geared towards state preparedness for the millennium bug, the government appointed a National Y2K Steering Committee in October 1998 (Waema, 2005). In its 2000 Final Report, the Committee recommended that ICT be "made an integral and critical component of national and regional economic and social development" (as cited in Waema, 2005, p. 4).

After a series of failed efforts to move forward the formulation of a national ICT policy in 2001 and 2002 (Eldon, 2005), the process got a major impetus in March 2003. 
The new government that came to office in January 2003 was determined to demonstrate that it was different from the previous one. Hence, it called for an Economic Recovery Conference in March 2003. Two events make this conference significant in the ICT policy-making process. First, the conference established a select committee that would collate views and formulate a draft ICT policy document. The other event was the formation of the Kenya Private Sector Alliance (KEPSA), which came about when the government urged the private sector to "speak with one voice" (Eldon, 2005). Hence, KEPSA's primary objective is "to provide a unified voice of the private sector so as to influence public policy formation" (KEPSA, 2007). The organization's landmark achievement is that it is represented in policy-making processes in all ministries through a public-private partnership program known as Ministerial Stakeholders Forums (ibid.). In 2003, KEPSA formed its ICT arm, the Kenya ICT Federation (KIF), and for eight months from August 2003 to March 2004, KIF held seven workshops that linked ICT to other sectors such as education, health, and trade (Nduati \& Bowman, 2005). In addition, the Kenya ICT Federation invited the government along with the private sector, civil society, and development agencies to an ICT Integration Workshop on February 13, 2004 (ibid.). The workshop appealed to the government to speed up the process of formulating an ICT policy for Kenya (ibid.). In June 2004, the select committee launched in the 2003 Economic Recovery Conference finished drafting the policy, but its circulation was restricted to senior government officials (Waema, 2005). A newly appointed minister for information and communications rejected the draft and directed the select committee to write another one (ibid.). By October 2004, a "revised" draft was ready for circulation. Waema observes: "This document appears to be not much different 
from the June 2004 version" (p. 14). The government released the draft to the general public in November 2004, and in January 2006 it launched The National Information \& Communications Technology (ICT) Policy.

Tanzania: The story of Tanzania's ICT policy-making process can be traced back to late 1998 when the government launched the National Bug (Y2K) Campaign (Sawe, 2005), which inspired eight of its participants to focus on ICT-related issues (Association for Progressive Communications, 2002). This group of chief executives, mostly from the private sector, resolved to meet once a week. Their first meeting took place on February 8,2000 , and by the end of 2001 , the membership had risen to 200 ; in 2003 , it stood at 700 (ibid.). These social elites referred to themselves as eThinkers, and their organization as eThinkTank-Tanzania. Records show that in 2000, the eThinkers worked for African Online (Tanzania), Alpha Internet Café, Capital Finance, CDC Capital Partners, Cisco Systems, Citibank (Tanzania), CRDB Bank, Infotech Computers, KPMG Consultants, Micronix Systems, Raha.Com, Tanzania.Com, Tanzania Development Finance Limited, Tanzania Telecomunications Company, Wilken Afsat, and Yellow Pages (eThinkTankTz, 2000). Current development partners include the World Bank, the United Nations Development Programme, the G-8 Digital Opportunities Task Force, and the Netherland's International Institute for Communication and Development (eThinkTank-Tanzania, 2007).

In 2001, Tanzania's minister for communications and transportation created a Task Force on National ICT Policy whose main task was to formulate an ICT policy. The Task Force's members from the private sector were all eThinkers (ibid.). On December 
13, 2001, these eThinkers submitted a draft ICT policy to the Task Force, and building on that document, the Task Force produced another draft, which entered the public domain on March 25, 2002 (ibid.). After feedback from parliamentarians and other stakeholders, the Task Force reviewed the draft and submitted it to the cabinet for approval in March 2003. The document became Tanzania's National Information and Communications Policy in July 2003.

Uganda: As noted earlier, Uganda emerged from its condition of state collapse in the late 1980s. This transition also involved a commitment to market-based public policies; moreover, it attracted major development agencies-the World Bank, the International Monetary Fund (IMF), Canada's International Development Research Centre (IDRC), the United Nations Economic Commission for Africa (UNECA), and the United Nations Educational, Scientific and Cultural Organization (UNESCO). These development agencies played a visible role in Uganda's ICT policy-making process.

The government of Uganda, through its National Council for Science and Technology, established a National ICT Policy Task Force in 1999, which worked in conjunction with the Y2K Task Force and government ministries (Government of Uganda, 2003). With support from IDRC, UNECA and UNESCO, the Task Force organized a National ICT Policy Framework in September 2000, which drew participants from the public and private sectors as well as from academia and civil society (UNECA, 2007). This workshop "discussed background information on the development of ICT and identified institutional framework and key policy issues that need[ed] to be addressed" (ibid.). 
Another event in 2000 that contributed to the ICT policy-making process was the forming of the Uganda Information Infrastructure Agenda Project (UIIAP). The Project is managed by the government, Makerere University and the World Bank, and its task manager is a principal telecommunications specialist with the World Bank (Makerere University, 2007). In 2001, the Project held workshops, symposia and focus group discussions on ICT issues, and its August report of that year observed: "Uganda requires leadership from the highest government and corporate levels to energize its ICT policy formulation" (p. 4).

In late 2001 and early 2002, the National ICT Policy Task Force held consultations with senior public and corporate chief executives, the Uganda Information and Infrastructure Agenda Project, the Uganda Investment Authority, the then Ministry of Information, and Perwit International (Canada) among others (Government of Uganda, 2003, p. 12). The Task Force released its first draft in May 2002. After reviewing it, the government adopted the document in October 2003 under the title National Information and Communication Policy.

\section{Networking and Knowledge Production}

What is the significance of the African Information Society Initiative in national ICT policy-making processes in East Africa? A Foucauldian epistemology foregrounds the argument that such networks can be conceptualized as "knowledge producing networks" (Bridge, 1997; Kendall, 2004). From this standpoint, networks (re)produce not only power relations (as noted earlier) but also particular forms of knowledge. I identify three sets of ideas to which East African governments as network enrollees of the African 
Information Society Initiative are expected to subscribe. The first tenet is that of adopting a broader conception of information technologies (IT). In the 1980s, the United Nations Economic Commission for Africa promoted the use of IT in libraries, archives and documentation centres $(1999$, p. 2). The launching of the African Information Society Initiative marked the shift from IT, largely viewed as computer hardware and software, to "information and communication technologies" (ICT). The Initiative included computer technology in ICT as well as telephony, broadcasting, the Internet, and satellite technology (UNECA, 2003 [1996], pp. 15-21). This expanded view of ICT was unconventional before the Initiative was launched in 1996, given that UNESCO was guiding Kenya in the formulation of an IT and not an ICT policy in 1993 (Ochuodho \& Matunga, 2005).

The other tenet is that of regarding ICT as the panacea for African underdevelopment. Before the Initiative was formed, African governments, UNECA and UNESCO considered IT as tools for efficient gathering and storage of information in bureaus of statistics and libraries, among other institutions (ibid.). In adopting the Initiative, the UNECA Conference of Ministers of May 1996 took the unprecedented step of declaring ICT the solution to African under-development: ICT will "accelerate development in all spheres of African economic and social activity" (UNECA, 2003 [1996], p. 1). The Initiative postulates that ICT can facilitate job creation, preservation of cultures, provision of health care, promotion of tourism, alleviation of natural and human-made crises, food security, education and research, gender and development, and trade and commerce (ibid., pp. 5-9). This mode of thinking permeates ICT policies and strategies in East Africa (as highlighted in chapters four and five). 
Finally, the Initiative teaches that the private provision of ICT services is the approach best suited for Africa. As a result, the Initiative gives primacy to neoliberal practices of market liberalization and privatization, and it urges African governments to implement these practices so that the private sector can provide ICT services in such areas as telephony and broadcasting (UNECA, 2003 [1996], p. 11). As well, in order to safeguard competition within the ICT sector, UNECA expects African governments to establish regulatory agencies (ibid., p. 4). The special place accorded to the private sector by the Initiative has motivated the private sector in East Africa, especially in Kenya and Tanzania, to play a key role in ICT policy-making processes.

The African Information Society Initiative owes its very existence to the calculative practice of networking. One important aspect of this practice is that it has produced three powerful notions: ICTs include information and other technologies; the application of ICTs can bring about development in Africa; and the private sector is central to efficient provision of ICT services. These tenets contribute to global neoliberalism in the issue-area of ICT, and they have shaped the ICT policy-making processes in East Africa. The following section seeks to link the African Information Society Initiative and ICT policy-making processes to neoliberal global governance.

\section{Networking and Neoliberal Global Governance}

I have attempted to show that the calculative practice of networking has underpinned ICT policy-making processes in East Africa, and that the African Information Society Initiative is one of the key factors that have influenced those processes. In line with the conception of networking as a form of governance (Dicken, Kelley, Olds \& Yeung, 2001, 
p. 92), the Initiative is a governance project of a particular kind-that is, neoliberal global governance. This position can be explained through Michel Callon's translation perspective ${ }^{26}$, especially the "moment of enrolment". Callon defines "translation" as that situation whereby individuals and institutions align their interests with those of others, and in the process, establish a meeting of minds (1986, p. 201). From a translation perspective, the taken-for-granted "meeting of minds" between African governments and the United Nations Economic Commission for Africa obscures the asymmetrical power relations perpetuated through the African Information Society Initiative.

To unpack the power relations embedded in the Initiative as a project of neoliberal global governance, I revisit the "moment of enrolment" in the translation process. This moment brings to the fore the power relations between the two main categories of network members: enrollers and enrollees (Dicken, Kelly, Olds \& Yeung, 2001, p. 104). Network enrollers, whether individuals or institutions, form the initial network, define its mission, and continue to sustain it through retention of current enrollees and enlistment of new ones. In the case of the African Information Society Initiative, institutions such as the World Bank and the United Nations Economic Commission for Africa are network enrollers, while African governments are network enrollees.

In the translation process, Initiative enrollers argue that the key catalyst of economic development is ICT and that implementation of the African Information Society Initiative at the national level will bring about prosperity. On their part, African governments find this line of reasoning persuasive, so they enroll in the African

\footnotetext{
${ }^{26}$ On incorporation of Michel Callon's translation perspective within governmentality studies, see Nikolas Rose (1999), Gavin Kendall (2004) and Richard Le Heron (2007).
} 
Information Society Initiative. In other words, the Initiative is underpinned by two different sets of interests: the enrollers seek to create an African Information Society, whereas the enrollees long to solve the perennial problem of under-development. This consensual relationship gives enrollers an upper hand in the sphere of knowledge production.

The enrollers conceptualize the social world in a certain way. Specifically, they uphold three sets of ideas: information and communication technologies transcend computer hardware and software; information and communication technologies are catalysts of economic development; and neoliberal practices of market liberalization and privatization promote economic development. Enrollers expect enrollees to commit themselves to these tenets. As noted earlier, East African governments have in fact adopted market liberalization and privatization. It can, therefore, be argued that the Initiative enrollers have succeeded in molding national communications sectors according to their own economic priorities. Indeed, initiative enrollers have used neoliberal global governance-a power resource granted to them by the network-to shape East African communications transformations.

\section{“Neoliberalizing” East African Communications Transformations}

Chapter One proposed four dimensions of East African communication transformations: substantive, epistemic, calculative, and ontological. This chapter has focused on calculative and substantive dimensions, and is based on the claim that calculative practices produce substantive manifestations of communications transformations. This way of thinking is an attempt to link East African communications transformations to 
economic globalization and neoliberal global governance, as well as to international development organizations as implementers of calculative practices of neoliberalization. In performing practices of neoliberalization, international development organizations such as the World Bank and the United Nations Economic Commission for Africa gain from the power resource of neoliberal global governance and produce knowledge and practices that promote economic globalization. I have attempted to show that the communication-specific tenets of global neoliberalism and the calculative practices of international development organizations are at the heart of on-going changes in East African mediascapes. In this regard, the chapter provides the example of the African Information Society Initiative and seeks to illustrate how the calculative practice of networking has contributed to the creation of national ICT policies in East Africa, and that these policies play a part in the changes in East African mediascapes.

The chapter has also tried to demonstrate that East African governments have used the practices preferred by international development organizations-corporatization, commercialization and liberalization—to restructure national broadcasting sectors. Moreover, it has sought to establish that the World Bank in the 1990s employed the calculative practice of performance benchmarking, which led to changes in the East African telecommunications sector. As expected, recent changes in broadcasting and telecommunications in East Africa have unleashed competition, and to safeguard profitmaking, communication firms are engaged in the calculative practices of cross-media ownership and acquisition. This chapter provides examples of practitioners of crossmedia ownership (Nation Media Group and Industrial Production Promotion) and acquisition (Celtel International and Africa Online). 
The present chapter has attempted to establish that calculative practicespreferred practices, performance benchmarking, networking, cross-media ownership and acquisition-have spread economic globalization within East African mediascapes. In turn, these practices have generated substantive (observable and quantifiable) changes. In short, then, the chapter has dealt with two of the four dimensions of East African communications transformations: calculative and substantive. The other aspect-the ontological dimension - has already been covered in chapter one. The rest of this study delves into the epistemic dimension. The next chapter presents the methodological orientation and research method that I apply to the study of the epistemic dimension of East African communications transformations in chapters four and five. 


\section{CHAPTER THREE}

\section{EPISTEMIC GENEALOGY, GLOBAL GOVERNMENTALITY, AND CRITICAL FRAME ANALYSIS}

There is no power relation without the correlative constitution of a field of knowledge, nor any knowledge that does not presuppose and constitute at the same time power relations. (Foucault, 1977, p. 27)

Economic globalization is a form of governmentality in that it is implemented through calculative practices, upholds a distinct power relationship, and draws from a particular knowledge-form. This argument-advanced in chapter one-is the entry-point to research on the intertwinement of economic globalization with East African mediascapes from an epistemic genealogical perspective. This perspective is based on three premises of a global governmentality epistemology: power is a resource, global neoliberalism is not the only view of the social world, and the problematization of social life is central to neoliberal programmes of governance. A global governmentality epistemology views power as a resource that produces "things"-including knowledge forms, and as such, neoliberal global governance creates the political rationality of global neoliberalism as well as the calculative practices of neoliberalization, such as market and trade liberalization, corporatization, commercialization and privatization. Chapter two has tackled the practice of calculation; this chapter focuses on the practice of knowledge production.

Furthermore, a global governmentality epistemology argues that global neoliberalism is a political rationality that articulates one version, rather than others, of the social world. To distinguish and promote that particular conception of the social world, international development organizations and East African governments have 
engaged in constructing programmes of governance for national economies, including the communications sector. One of the main programmes of governance in the ICT policymaking processes in East Africa (as discussed in chapter two) is the African Information Society Initiative directed by the United Nations Economic Commission for Africa in partnership with the World Bank, among other international institutions. Other programmes of governance examined in this dissertation are the ICT policies of the World Bank and East African governments, and Kenya's strategy for ICT's role in economic development.

Finally, a global governmentality epistemology holds that neoliberal programmes of governance emerge from the problematization of social life. I develop this argument in the rest of this introductory section as an entry-point to the proposed epistemic genealogical perspective. This perspective is inspired by Nikolas Rose who, with Peter Miller, conceptualize problematization as "the way in which experience comes to be organized so as to render something as a 'problem' to be addressed and rectified" (1995, p. 429). An epistemic genealogical study, therefore, seeks to investigate how programmes of governance pose an issue as a social problem, and offer a solution based on a particular conception of the social world, or political rationality (O'Malley, Weir \& Shearing, 1997, pp. 501-502). It is this process of the problematization of economic under-development in East Africa, with specific reference to the issue-area of communications, that this dissertation seeks to examine.

According to Rose, the main task of an epistemic genealogist is "to reconstruct the problematizations to which programmes, strategies, tactics posed themselves as a solution" (1999, p. 58). From this viewpoint, analyses of programmes of governance- 
for example, ICT policies and strategies-constitute an epistemic genealogical study of East African communications transformations. One of the main advantages of this approach is that it attempts to unearth the knowledge forms underpinning programmes of governance (Mahon, 1992, p. 120). In the case of this dissertation, I use an epistemic genealogical approach to extract knowledge forms from the communications-related programmes of governance of the World Bank and East African governments. The key point is that such an exercise will help in reconstructing the specific knowledge forms that underlie and entrench communications transformations in East Africa.

However, it has to be noted that an epistemic genealogy is a "mode of research" (Mahon, 1992, p. 120) rather than a research method. As a mode of research, an epistemic genealogy proposes a way of thinking about programmes of governance, but fails to offer research tools for "reconstructing [the] problematization" underlying programmes of governance. Given that programmes of governance are presented in the form of texts, which articulate plans, strategies, policies and visions, I hold that a research method drawn from document research can facilitate the study of the epistemic dimension of East African communications transformations. In order to carry out this task, I intend to use frame analysis, especially its critical strand.

In this chapter, I situate frame analysis within document research and explain why this research method is suitable for the study of programmes of governance. One of the main hindrances to using frame analysis is that it is divided among three strands that stem from opposing philosophical and methodological traditions: positivism, interpretivism, and critical philosophy or methodology. I navigate through positivist, interpretive and critical frame analysis, and argue that the critical orientation provides the research tools 
needed for examining the epistemic dimension of East African communications transformations. The chapter also clarifies the issue of "criticalness" in critical frame analysis by postulating that critical frame analysts, unlike positivist and interpretative frame analysts, use the lenses of critical social theorists to interpret data. In this dissertation, I draw insights from critical social analysts Antonio Gramsci (1891-1937) and, of course, Foucault. In concluding this chapter, I propose the compatibility of critical frame analysis with the global governmentality perspective.

\section{Document Research and Frame Analysis}

Document research involves analyzing records-whether in audio, visual or written form (Prior, 2003, p. 2; Scott \& Marshall, 2005, p. 164). Examples of documents include newspapers, magazines, audio and video recordings, films, photographs, conference proceedings, government records and publications, policy documents, websites, databases, computer files, architectural plans, maps, paintings, advertisements, shopping lists, diaries, nutrition facts of products, and funerary monuments. Among research methods that social analysts use to examine documents are content analysis, discourse analysis, frame analysis, narrative analysis, rhetorical analysis, and semiotic analysis (Alasuutari, 1995). The most important decision that a document analyst has to make is to determine which research method best suits the research project at hand.

I have chosen frame analysis because it allows this dissertation to make three main shifts: micro- to macro-analysis of text, text to context, and context to networks. Document research methods focus more on analyzing text at the micro-level, that is, words, sentences, metaphors, concepts, signs and symbols (e.g., the version of critical 
discourse analysis practised by Fairclough, 2003). While micro-text analysis has its rightful place in document research, it is cumbersome when applied to large amounts of text, for example, annual and issue-specific publications of international organizations such as those of the World Bank. Frame analysis helps in conducting document research at the macro-level of "frames"- the organizing principle of an entire document or large portions of it (Reese, 2003). I expound on the concepts of "frames" and "framing" later. In addition, frame analysis can assist in examining the contexts of documents. Lindsay Prior (2003) has posited that a document can be analyzed at three fundamental levels: content, production, and consumption. She applies Harold Garfinkel's and Harvey Sacks's ethnomethodological perspective to the study of documents, and argues that investigating the context in which a document is produced and consumed is as important as analyzing its content ${ }^{27}$ (pp. 30-88). An ethnomethodology of the production context of documents involves examining the process documents go through before they become finished products. In relation to an epistemic genealogical perspective, documents are produced through the process of problematization of social life. Individual authors as well as institutional agents identify social problems, analyze them and propose possible solutions. In the context of consumption, an ethnomethodological approach adopts the worldview of reflexivity, which advocates the position that "words or texts [do] not merely represent some aspect of the world, but ... they are also involved in that world" (p. 51). Studying documents, then, entails investigating how people put them into use in

\footnotetext{
${ }^{27}$ John Scott and Gordon Marshall note that "ethnomethodology" can be conceptualized as “"ology' (the study of) 'ethno' (people's) 'method' (methods) of creating social order" (2005, p. 199). Ethnomethodologists insist that people create, and re-create, the social world through individual and collective actions (ibid.; see also, Heritage, 2000).
} 
real life, and how that usage shapes the social world in terms of maintenance and/or modification of existing social relations, beliefs, values, practices, and identities.

Finally, a text can be conceptualized as a network. ${ }^{28}$ Michel Callon (1991) argues that the network of a text starts with a network of authors. He supports this claim by providing two main instances when a network of authors is possible in a text. The first is that of a text that has more than one author. A multiple-authored text is predicated on interaction, or networking, among various authors and cross-fertilization of their conception of the world. The outcome of such networking is a network of ideas presented in a particular text. As texts, programmes of governance within a liberal democratic context emerge from the networking of representatives of various social organizations, as shown in the previous chapter in the context of ICT policy-making processes in East Africa.

Most significantly, texts in their capacity as networks enhance their credibility by quoting other authoritative texts and providing bibliographies. What texts do, then, is to "rework cited texts, insert them into new relationships, and identify and link new actors together" (Callon, 1991, p. 135). The problem with East African ICT programmes of governance is that governments have concealed their non-domestic sources by not providing a complete list of sources. In this vein, East African governments implicitly present these programmes as outcomes of consensus between the public and private sectors as well as the civil society. The aim of this epistemic genealogical study is to provide evidence that shows that the knowledge-forms of East African ICT programmes

\footnotetext{
${ }^{28}$ Michel Foucault once observed: "The frontiers of a book are never clear-cut: beyond the title, the first lines and the last full stop, beyond its internal configuration and its autonomous form, it is caught up in a system of references to other books, other texts, other sentences: it is a node within a network (Foucault, 1970, p. 23; emphasis added).
} 
of governance emanate from the World Bank's ICT programmes of governance. In addition, the study provides evidence to the effect that the epistemic foundations of ICT news reporting in Kenya's Daily Nation newspaper emerge from the Government of Kenya's strategy for ICT in economic development.

Frame research can facilitate analysis of the content, context and networking of documents, but the effectiveness of the method depends on whether the strand used offers the tools of analyzing the framing process and related frames (I will return to this point later when discussing strands of frame research). Paul D'Angelo (2002) proposes three paradigms of frame research: cognitivist, constructionist, and critical. He delineates each paradigm's worldview but fails to explain why a particular paradigm is different from the others in terms of its research design and trajectory of theory construction. I address this issue by navigating through frame analysis from a social science methodological perspective. ${ }^{29}$

\section{Navigating through Frame Analysis}

In order to transcend D'Angelo's quandary, I have revisited the philosophy of social science, especially its four sets of methodologies: positivism, logical rationalism,

\footnotetext{
${ }^{29}$ A methodological perspective of the social sciences accounts for the role of methodology in conceptualizing and designing a research project as well as selecting an appropriate research method. Within this perspective, "methodology" is held to be different from "research method" in that the latter refers to "techniques or procedures used to collect and analyze data" (Blaikie, 2000, p. 8). Examples of research methods include experiments, surveys, case studies, historical analysis, participant observation, critical discourse analysis, and frame analysis. "Methodology" refers to self-contained traditions of studying phenomena (within social sciences) which have distinct research strategy and rationale in addition to ontological and epistemological assumptions (Fay, 1975; Blaikie, 2000; Mackay \& Reynolds, 2001; Sanghera, 2004). The most notable social scientific methodologies are positivism, logical rationalism, interpretivism, and critical methodology (see discussion that follows).
} 
interpretivism, and critical methodology (Fay, 1975, 1987; Blaikie, 1993, 2000;

Sanghera, 2004). The tendency within communication studies is to refer to positivism as comprising the logical rationalist and positivist methodologies of social science (see for example, Griffin, 1997; Severin \& Tankard, 2001; Littlejohn \& Foss, 2005). Following Brian Fay's (1975) tripartite division of social science, I categorize frame research in three camps: positivist, interpretive, and critical. The usefulness of this taxonomy is that it sorts out various works in frame research according to their adherence to a specific methodology of social science; moreover, it distinguishes each camp from the other through its unique research rationale. Finally, the taxonomy facilitates the construction of critical frame analysis as a distinct strand. The following section highlights the defining features of each strand of frame research, and situates this dissertation within the strand of critical frame analysis.

\section{Positivist Frame Analysis}

Positivist frame analysis is traceable to the founding moments of political communication studies. David Michael Ryfe (2001) observes that social psychology, political science and communication studies (of the media effects tradition) formed the foundation on which political communication studies emerged in the 1970 s. Intrinsic to the three disciplines is a positivist-inclined methodology that permeates frame analysis within political communication studies (see, for example, Iyengar, 1991; McLeod \& Detenber, 1999; Scheufele, 1999, 2000; Semetko \& Valkenburg, 2000; Bantimaroudis \& Ban, 2003; Mabry, 2003; McCombs \& Ghanem, 2003; Miller \& Riechert, 2003; Nelson \& Willey, 
2003; Shah, Domke \& Wackman, 2003; Tankard, 2003; de Vreese, 2003; Gan, Teo \& Detenber, 2005; Wicks, 2005; Davidson, 2006).

Dietram Scheufele observes that frames are "schemes for both presenting and comprehending news," and proceeds to distinguish two sets of frames: individual/ audience (mental schemata of interpretation) and media frames (content of media products) (1999, pp. 106-107). Positivist frame analysts Claes de Vreese (2003), T. Michael Maher (2003), Maxwell McCombs and Salma Ghanem (2003), and Robert Wicks (2005) find the roots of frame analysis, especially the tradition of investigating individual/audience frames, in Walter Lippman's Public Opinion (1922); Gregory Bateson's 1955 article “A Theory of Play and Fantasy" in his Steps to Ecology of Mind (1972); and Erving Goffman's Frame Analysis (1974). Lippman, Bateson and Goffman share the view that human beings use cognitive processes to decipher numerous pieces of information encountered in daily life. This emphasis leads positivist frame analysts to work within the broad movement of cognitivism, which entered into communication studies in the 1940s and 1950s through Kurt Lewin's experiments on group communication, Leon Festiger's theory of cognitive dissonance, and Fritz Heider's theory of cognitive balance (Rogers, 1994; Wicks, 2005).

Cognitivists argue that human behaviour is a result of decisions that individuals make through the cognitive processes of "attention, perception, language, learning, memory, problem solving, and thinking" among other factors (American Psychological Association, 2007, p. 190; see also, Solso \& MacLin, 2000, p. 150). Unlike behaviourists, who postulate that a stimulus (e.g., media violence) brings about a specific response (real-life violence), cognitivists hold that cognitive processes intervene between stimulus 
and response (Balota \& Cortese, 2000, p. 153). Along the lines of cognitivism, positivist frame analysts focus on studying the "power of a communicating text" to influence cognitive processes and, ultimately, human behaviour (Entman, 1993, pp. 51-52; see also, Price \& Powers, 1997). The main focus, then, is to examine media texts and correlate "salient" features of a text to an individual's perception of particular aspects of public discourse (p. 53). If media frames correlate to individual/audience frames, positivist frame analysts conclude that the former influence an individual's cognitive processes, which, in the long run, will affect behaviour. It follows from this way of reasoning that frame research is embedded in the media effects paradigm or the socio-psychological tradition of mass communication studies (Scheufele, 1999, 2000; McCombs \& Ghanem, 2003; Wicks, 2005; for the socio-psychological tradition, see Craig, 1999; Severin \& Tankard, 2001; Littlejohn \& Foss, 2005, pp. 42-44).

Positivist frame analysts adopt falsification as their research rationale, which forms the basis of research within positivism (Fay, 1975; Blaikie, 2000; Sanghera, 2004). The falsification rationale requires researchers to identify regularities of events or phenomena and relate them to an existing theory. From that theory, researchers derive one or more hypotheses, and in some cases they can formulate new ones. The point is to test through statistical analysis of quantitative research whether hypotheses can be corroborated by available data. If data confirm a hypothesis, then the latter reflects social reality. The hypothesis should, therefore, be preserved. If there is insignificant correlation of data and hypothesis, the latter is discarded. Hypotheses that withstand various tests become tentative theories, which can be applied to the study of similar cases over time and space. 
Two main factors militate against using positivist frame analysis in this dissertation: it gives primacy to micro-analysis of documents, thereby neglecting the macro side of analysis; and it lacks a research focus on the framing process—and that, by itself, brackets out the study of the production and consumption contexts of documents. Being able to examine the content and context of policy documents of the World Bank and East African governments is central to investigating the epistemic underpinnings of East African communications transformations.

\section{Interpretive Frame Analysis}

As with the positivist strand, interpretive frame analysis is a well-established research method (see for example, Tuchman, 1978; Snow et al., 1986; Snow \& Benford, 1988; Gamson \& Modigliani, 1989; Benford \& Hunt, 1992; Snow \& Benford, 1992; Gamson, 1992, 1996; Benford, 1997; Fisher, 1997; Tucker, 1998; Pan \& Kosicki, 2003; Snow, 2004; Snow \& Benford, 2000, 2005). Interpretive frame analysts John A. Noakes and Hank Johnston (2005) credit Gregory Bateson (1972 [1955]) and Erving Goffman (1974) for introducing the "frame" concept into social science and sociology, respectively. They regard Todd Gitlin (1980) as the pioneer scholar of frame research within the political sociology of social movements.

Noakes and Johnston, however, criticize Gitlin for paying far too much attention to the study of framing within media organizations (in this case, the New York Times) with little concern for examining the same process within social movements (specifically, in his case, the Students for a Democratic Society). The two scholars hold that William Gamson, Bruce Fireman, and Steven Rytina, in their book Encounters with Unjust 
Authority (1982), shifted frame research from Gitlin's media focus to a social movement centered perspective. Noakes and Johnston recognize Gamson and David Snow, along with their associates, as having played a significant role in the evolution of frame research in social movements since the 1980s.

Snow's camp has had more impact than Gamson's because of its penchant for formulating concepts that have turned out to be central to frame research (Snow et al., 1986; Snow \& Benford 1988, 1992; Noakes \& Johnston, 2005). The camp emphasizes "framing" as the linchpin concept, and its derivative concepts of collective action frames, and core framing tasks. Snow and Robert Benford conceptualize "framing" as "signifying work"- that is, the process in which movements "assign meaning to and interpret relevant events and conditions in ways that are intended to mobilize potential adherents and constituents, to garner bystander support, and to mobilize antagonists" (1988, p. 198; see also, 2005, p. 206). This framing process produces a "collective action frame"-that is, a documented plan of action that promotes a particular interpretation of an issue, event, or phenomenon (Noakes \& Johnson, 2005, p. 5). The process is also divided into three "core framing tasks": diagnostic framing_identify a problem and attribute blame; prognostic framing —offer a remedy to the problem at hand; and motivational framingconvince people to accept the recommended cause of action (ibid.). I incorporate core framing tasks into critical frame analysis and use them as tools for data collection (see chapters four and five).

In general, interpretive frame analysts adhere to Goffman's sociological theory of dramaturgy, which is an offshoot of the broader theoretical framework of symbolic interactionism (Benford \& Hunt, 1992; Fisher, 1997; Snow \& Benford, 2000). The 
theory's entry-point to social research is guided by the following saying: "All the world is a stage and all the people players" (Scott \& Marshall, 2005, p. 168). Hence, dramaturgists assume that people are "actors on a metaphorical stage playing out roles" (Littlejohn, 1996, p. 165). Robert Benford and Scott Hunt (1992) identify four strategies of the dramaturgical perspective relevant to the application of frame analysis to social movements: scripting, staging, performing, and interpreting.

Scripting is an attempt to describe the situation, assign roles to various actors, and identify expected attitudes and behaviour change among a collectivity. Staging involves taking into account the logistics of organizing a protest, the careful selection of symbols capable of conveying a movement's message, tailoring messages to target audiences, and planning for publicity campaigns. Performing entails challenging existing power relations through actual protest, transforming bystanders into active participants in a cause, encouraging commitment to the movement's framing of issues, and maintaining discipline within ranks. Interpreting comprises offering an interpretation of grievances while preparing responses to polysemic interpretations of the preferred frame of protest. According to interpretive frame analysts, the success of movements depends on how activists utilize dramaturgical strategies, and above all, how activists frame grievances, mobilize support for frames among members and the general public, and uphold frames in the face of resistance and polysemic interpretation. Underlying the four strategies and other aspects of the theory of dramaturgy is interpretivism—a philosophy and methodology of social science.

Interpretivism is based on the research rationale of interpretation of talk, text, and social action (Fay, 1975; Blaikie, 2000; Sanghera, 2004). Interpretive researchers assume 
that human beings construct the social world by assigning meanings to their actions and interactions with others. Researchers seek to study the social world by participating in a social group and thereby obtaining an "inside" account of a shared worldview and goaloriented actions. It is anticipated that all data will come from a social group, and that researchers will interpret lay terms and meanings through the technical language of the social sciences. What is important, though, is that researchers formulate concepts, perspectives and theories that come from people's interpretation of everyday life, particularly through language, conversations, practices and relationships. Interpretive frame analysts seek to interpret the collective actions of activists, especially how core framing tasks and collective action frames are reinforced through dramaturgical strategies. The interpretive strand of framing research is too centered on social movements, and as such, it can only be of value to mass communication researchers if it is adapted to their field of study. For example, in reconstructing critical frame analysis (in the following section), I have borrowed the "core framing tasks" of diagnosis, prognosis and motivation from interpretive frame analysis.

\section{Critical Frame Analysis}

Critical frame research lacks both academic cohesion and the status of positivist and interpretive frame research. In addition to having an accumulated literature and core concepts and perspectives, the positivist and interpretive strands are established schools of thought. As for the critical strand, it is the work of individual scholars who refuse to operate within the broader media effects tradition of mass communication studies, of which positivist frame analysis is part. Instead, critical frame analysts associate 
themselves with critical social theories-specifically, Gramsci's theory of hegemony and Stuart Hall's work on ideology.

By introducing the Gramscian perspective into frame research, Todd Gitlin (1979, 1980) stands out as the founding scholar of critical frame analysis. Other scholars I characterize as critical frame analysts include Robert Hackett (1984), Stephen Reese (1990, 2003), Bob Buckalew (with Reese, 1995), Roya Akhavan-Majid and Jyotika Ramaprasad (1998), Donna Dickerson (2003), Frank Durham (2003), Oscar Gandy, Jr. (2003), Tamara Goeddertz and Marwan Kraidy (2003), James Hertog and Douglas McLeod (2003), and Kevin Carragee and Wim Roefs (2004). I have reviewed works of these scholars, and what emerges is that critical frame analysts share particular commitments that distinguish them from positivist and interpretive proponents of frame research. They study "media frames" without drawing from the media effects tradition of mass communication studies; examine the intersection between media and social movements; break with the thinking that news reflects reality; and maintain that ideology is implicated in media framing processes. I regard these commitments as defining premises of critical frame analysis, and adopt this research method as indicated in the following exposition.

Media Frames: Critical frame analysts refuse to do research on framing effects as positivist analysts do. Rather, they seek to study "media frames," which Todd Gitlin defines as "persistent patterns of cognition, interpretation, and presentation of selection, emphasis and exclusion, by which symbol handlers routinely organize discourse whether verbal or visual” (1980, p. 7). Stephen Reese has refined Gitlin's definition as follows: 
"Frames are organizing principles that are socially shared and persistent over time, that work symbolically to meaningfully structure the social world (2003, p. 11).

From Reese's definition, a media frame focuses on a specific aspect of a social phenomenon and offers a particular way of thinking about it (pp. 12-14). For example, the World Bank's globalization frame promotes economic development of nation-states through the capitalist path of adjusting to liberalization, privatization and liberal democracy. Another aspect of Reese's definition is that a media frame has to be studied from a holistic perspective that views frames as operating at two levels: the "symbolic manifestation" of audio, visual and written forms; and the unobservable "organizing principles" underlying "symbolic manifestation" (pp. 14-15). The World Bank's media products contain symbolic manifestations of media frames that are based on the organizing principles of global neoliberalism (as highlighted in chapter four).

The third observation on Reese's definition is that media frames emerge from a shared framing process that aims to expand commonsense thinking and interpretation of the social world (p. 15). For instance, the production of a television news item, with its particular frame, is not a one-person project but a process involving reporters, videorecording personnel and editors, among others. And finally, Reese's definition emphasizes the persistence of media frames-that is, they permeate the routines of institutional agents and offer a readily available way of packaging messages (pp. 15-16). As shown in chapter four, the globalization frame has endured in the World Bank's publications for over fifteen years-thus it has persisted as the overriding frame. 
Media-Movement Interactions: Critical frame analysts are interested in investigating the interface between media and social movements. From the outset, it has to be noted that both interpretive and critical frame analysts seek to study media-movement interactions, but their foci are different. Interpretivists pay more attention to the social movement side and emerging collective action frames, while critical analysts are more concerned about the other side of media and the production of media frames.

Gitlin's early works emphasize the existence of a symbiotic relationship between media and social movements $(1972,1977,1980)$. This theme is especially prominent in his book The Whole World is Watching (1980), which is a frame analysis of news articles on the New Left Movement of the 1960s, particularly the Students for a Democratic Society (SDS). Gitlin studied how CBS News and the New York Times covered that movement. Gandy, Kopp, Hands, Frazer and Phillips (1997) as well as Goeddertz and Kraidy (2003) take Gitlin's lead in examining "antisystemic" (anti-capitalist/antiglobalization) movements. Critical frame analysts Reese and Buckalew (1995) and Akhavan-Majid and Ramaprasad (1998), on the other hand, have sought to study "systemic" movements that entrench capitalism and its worldview. Chapter four examines the systemic side of the globalization movement with a particular focus on the World Bank's impact on the epistemic dimension of East African communications transformations. The World Economic Forum, the World Trade Organization and the International Monetary Fund are among the organizations that belong to the systemic globalization movement. 
Conceptualizing the Framing of News: Critical frame analysts reject objectivist, reflective, and phenomenological approaches to news framing (Gitlin, 1980, pp. 247252). The objectivist worldview asserts that journalists uphold their professional integrity by sticking to journalistic objectivity whenever they are framing news. From this vantage point, journalists participate in the production of news in an objective way, i.e., devoid of distortion and bias. The reflective worldview postulates that media are "mirrors" to the world, and as such, their coverage of events captures what really happens in the world. Following this worldview, one can argue that, for instance, if a change in the media coverage of personalities and social movements occurs over time, it is not the media coverage that is changing, but what is being covered (p. 250). Both objectivist and reflective worldviews rule out the possibility of conscious and unconscious news bias, and as a result, media personnel who violate journalistic objectivity invite punitive action.

The phenomenological worldview seeks to demonstrate that journalists are vulnerable to unconscious news bias, which can come through training, reporter-editor relations, and everyday routines, especially those involving interaction with sources. This worldview brings to the fore the role of human agency-journalists and their practices-in the construction of news frames (Tuchman, $1978{ }^{30}$ ). Gitlin and other critical frame analysts admit that journalistic practices shed light on the news framing process, but insist that investigating the ideological foundations of news frames is central

\footnotetext{
${ }^{30}$ Gaye Tuchman's Making News: A Study in the Construction of Reality (1978) is the classic work within frame research that espouses a phenomenological perspective. Drawing from interpretive social scientists Alfred Schutz, Harold Garfinkel, Erving Goffman, and Peter Berger and Thomas Luckmann, Tuchman rejects the mirror metaphor of news production. Contrary to the mirror metaphor, she argues that "newswork transforms everyday occurrences into news events" (p. 186).
} 
to frame research. They adopt an ideological worldview towards news framing that is "post-Marxist" in principle.

Stuart Hall argues that "post-Marxists use Marxist concepts [and perspectives] while constantly demonstrating their inadequacy" $(1983$, p. 57$)$. In this sense, critical frame analysts are post-Marxists because they reject the classical Marxist approach to ideology and operate within the post-Marxist analysis of ideology. The classical approach draws from Marx's conceptualization of ideology as "false consciousness" in that the ruling class imposes its worldview on the working class, and the latter class holds to the ruling class's worldview as its own (Grossberg et al., 2006, p. 202). Classical Marxists have two primary tasks in the issue-area of ideology: to prove that the dominant worldview is not in the interest of the populace but in that of the ruling class; and to enlighten the masses on the "falsity" of the dominant ideology with the aim of creating the necessary conditions for revolt against the ruling class (Fay, 1975, 1987).

Critical frame analysts adhere to the post-Marxist approach to ideology, which argues that the defining feature of ideologies is not false consciousness but representations of the social world (Grossberg et al., 2006, pp. 205-211). The main argument is that groups of people, whether in dominant or dominated situations, seek to articulate their worldview through audio, visual and written forms of communication (Thompson, 1997, pp. 17-18). The aim is to attain ideological unity within and across other groups, and most importantly, to integrate its premises with widespread ideas, beliefs, attitudes and practices. This way of thinking emerges from Hall's study of ideology, particularly his exposition and application of Gramsci's theory of hegemony (1977a, 1977b, 1982, 1983, 1991). Within this worldview, Hall defines ideology as 
"patterns of ideas, belief systems, or interpretive schemes, found in a society or among specific social groups" (1989, p. 307).

Operating within the post-Marxist conception of ideology, critical frame analysts revisit Gramsci's theory of hegemony and argue for studying "hegemonic media frames" (Gitlin, 1979, 1980; Carrage \& Roefs, 2004). In general, hegemonic frames emerge from "hegemonic institutions" such as the family, the media, the education system, religious organizations, and museums (Hall, 1977b, p. 333). They are, therefore, byproducts of hegemonic institutions' struggle for consensus through engagement "in framing all competing definitions of reality within their range [and thereby] bringing all alternatives within their horizon of thought" (ibid.). However, it has to be noted that hegemonic frames in their very nature as a particular "definition of the situation" are never settled ways of interpreting the social world (Hall, 1977b, 1982). Their strength lies in their capacity to define parameters of debate - that is, they offer the framework of determining a legitimate from an unacceptable contestation of the "definition of the situation" (ibid.).

I subscribe to the post-Marxist approach to ideology because it accounts for the role of institutions in constructing specific conceptions of the social world. The approach provides a way of thinking about ICT programmes of governance in relation to hegemonic institutions - specifically, in this study, the World Bank, East African governments and the Daily Nation newspaper. It also directs attention to research on hegemonic frames that traverse the cited institutions. 


\section{Interpreting Data from a Critical Frame Perspective}

One of the distinctive features of critical frame analysis is that analysts interpret data through the lenses of critical social theorists, particularly Antonio Gramsci (Gitlin, 1980; Carrage \& Roefs, 2004). This feature contributes to the critical orientation of critical frame analysis along with the focus on hegemonic frames and the conception of news framing within the post-Marxist perspective of ideology (highlighted above). In this study, I propose to use epistemologies of Gramsci and Foucault in interpreting data presented in chapters four and five. First, I provide an exposition of Gramsci, and later, Foucault.

\section{A Gramscian Epistemology}

Gramsci, an Italian journalist, politician, political prisoner and Marxian philosopher, is known widely for his Selections from the Prison Notebooks (written between 1929 and 1935 and published in English in 1971). The book consists of fragments of notes that Gramsci wrote in prison in defiance of Italian dictator Benito Mussolini's infamous statement: "We must stop this brain from functioning for twenty years" (quoted in Bennett et al., 1981, p. 191).

Gramsci sought to explain why Karl Marx's thesis of revolution failed the test of time in the West. The Marxian thesis states that antagonistic relations between workers and the bourgeoisie would deteriorate over time to the extent that workers would have no other option but to overthrow the capitalist system and attain political power over the bourgeoisie (van Loon \& Osborne, 1999, p. 107). Gramsci argued that this thesis on 
revolution is ineffective because the bourgeoisie have not only political and economic power, but also the power of hegemony (Mouffe, 1981, p. 222).

To formulate his theory of hegemony, Gramsci linked a chain of concepts and perspectives, such as the centaur metaphor, historic bloc theory, national-popular concept, and passive revolution (Mouffe, 1979; Forgacs, 1988; Simon, 1991; Ransome, 1992; Kozolanka, 2003). Here, I draw attention to the concepts of "national-popular" (ideology) and "passive revolution." The Gramscian national-popular strategy is underpinned by the argument that "a class cannot achieve national leadership, and become hegemonic, if it confines itself only to class interests; it must take into account the popular and democratic demands and struggles of the people which do not have a purely class character, that is, which do not arise directly out of the relations of production" (Simon, 1992, pp. 24-25). From this standpoint, it can be argued that a class aspiring to become hegemonic has to include in its project the theme of democratization, which resonates with the general population, and also champion the interests of peasants, students, women, trade unions, and minority groups, among others. Just as a national religion can be hegemonic in terms of its worldview becoming the common-sense knowledge, so can an ideology if it synthesizes the interests of numerous social groups across the board.

This dissertation borrows the Gramscian national-popular concept and uses it in a more general sense in order to study the framing process that underlies the transformation of global neoliberalism into a national-popular rationality or ideology. Chapter four examines how East African governments have framed communications policies in a way that entrenches the World Bank's version of global neoliberalism as a national-popular 
mode of thought. The analysis of the Daily Nation's framing of ICT issues in chapter five demonstrates that this newspaper is involved in bringing global neoliberalism into the realm of common sense or common knowledge as a national-popular public discourse.

Fundamentally, the two chapters show that global neoliberalism has become a national-popular rationality that forms the epistemic foundation of the continuing transformation of East African mediascapes. In a Gramscian epistemology, these changes constitute a "passive revolution" in that national communications sector are being restructured "from above through the agency of the state apparatus [and international development organizations] without relying on the active participation of the people" (Simon, 1991, p. 50). The introductory and concluding chapters highlight implications of the passive revolution of East African mediascapes in terms of its encroachment on the democratic values of equity, participation and self-governance.

\section{A Foucauldian Epistemology}

Chapter one provides a theoretical framework of the Foucauldian perspective of governmentality and its relevance to the study of East African mediascapes. In this section I focus on how Foucault's conception of power can facilitate the interpretation of data on the epistemic dimension of East African communications transformations. One of Foucault's main contributions to the social sciences is his view of power as "productive" rather than being entirely "repressive." He rejected the negative conception that regards power as emanating primarily from "repressive" state apparatuses—-the army, police force and judicial system (1980, pp. 109-133). From this standpoint, "power is taken above all as carrying the force of prohibition," and consequently, the state, as the 
sovereign power in a country, requires individuals to abide by national laws (pp. 119, 122). Foucault regarded this negative conception of power as limited in the sense that it brackets out the study of power as a "productive network" (p. 119).

By adopting a positive view of power, Foucault conceptualized it as a resource that human beings use "to increase production, to develop the economy, spread education, raise the level of public morality; to increase and multiply (1977, p. 208). In order to study power as a resource, Foucault $(1977,1980)$ studied the interactions of individuals with social institutions, especially how individuals are subjected to investigations that lead to the formation of particular forms of knowledge. I highlight his thinking about specific social institutions and knowledge within the context of power relations, and in the course of doing so, underline his contribution to the interpretation of data within an epistemic genealogical study of East African communications transformations.

Foucault argued that "disciplinary power" emerges when individuals come into contact with "disciplinary institutions" such as prisons, factories, hospitals and psychiatric homes (1977, pp. 195-228). To explain disciplinary power, he used the panopticon metaphor, which he developed from Jeremy Bentham's (1748-1832) architectural design of a "panopticon" or "inspection-house." The term "panopticon" is a combination of two Greek words, opticon (to see) and pan (all); hence, it means "to see all" (Gill, 2003, pp. 135, 182-183). The purpose of a panopticon, then, is to enable possessors of disciplinary power "to see all" their objects.

Bentham (1748-1832) visualized a panopticon in its finished form to be a circular glass-built watchtower inside a huge building in which sentries would watch individual 
inmates within their segregated cells (1995 [1787], p. 35; Foucault, 1977, p. 200). He thought that the panopticon model was not only suitable for prisons but also for psychiatric homes, hospitals, schools, factories and poorhouses, among other social institutions. The logic behind Bentham's panopticon model was that those in authority could maintain surveillance over their subjects at all times. It is this "surveillance" function of the panopticon model on which Foucault focused, and he conceptualized it as constituting "disciplinary power" (1977, p. 207).

Within the panopticon model, possessors of disciplinary power use two primary modes of observing each individual: presence (of institutional agents such as sentries, nurses, medical doctors, teachers and preachers); and documentation (of personal information such as name, age, sex, birth place, marital status, and reason for being in the institution) (Foucault, 1977, pp. 196, 203-4). Possessors of disciplinary power are in a position to analyze such data, come up with ways of classifying individuals into groups, and identify common characteristics of individuals within each category. They can identify patterns from the data, and in turn, those patterns feed into the evolution of knowledge about a particular group of people. For example, through the study of prisoners and mental patients, criminology and psychiatry have become academic disciplines (Foucault, 1961, 1975). Thus, Foucault claimed: "There is no power relation without the correlative constitution of a field of knowledge, nor any knowledge that does not presuppose and constitute at the same time power relations" (1977, p. 27).

A Foucauldian epistemology underscores the centrality of collection and analyses of data as a fundamental mechanism of disciplinary power. The more information possessors of disciplinary power have on as many individuals as possible, the more they 
accumulate knowledge about certain categories of people, and the more they are effective in intensifying their surveillance. International development organizations, as possessors of disciplinary power, thrive on collecting data and measuring the political-economic performance of each country. In a Foucauldian epistemology, such data can be viewed as the main source of an emerging form of knowledge-global neoliberalism. It is this form of development knowledge that is (re)produced in annual reports and other documents of international development organizations, and above all, presented as scientifically-based knowledge that all countries should implement. This Foucauldian insight indicates that the World Bank's publications (analyzed in chapter four) contribute to disciplinary power. Hence, this study does not take collected data at face value; instead, it interprets such data using the Foucauldian perspective of disciplinary power.

\section{Critical Frame Analysis and Global Governmentality Perspective}

By adopting a social science methodological perspective, this chapter has classified frame analysis into positivist, interpretive and critical strands. The taxonomy indicates that frame analysis is not a homogenous research method because it is divided along the lines of the methodological orientation of the social sciences. Moreover, the chapter has identified the defining characteristics of each strand, and this categorization process has made it possible to construct the critical variant of frame research. What emerges is that the post-Marxist approach to ideology is implicated in the conceptual framework of critical frame analysis. Is this approach compatible with a Foucauldian perspective of global governmentality? 
In his intellectual development, Foucault encountered Marxism in its form as the guiding social philosophy of the French Communist Party (Foucault, 1991c), which he joined in 1950, but left in 1952 (pp. 51-52). Foucault's break with the French Communist Party as well as his dislike of Soviet-style communism (of the Stalinist variant) led him to "conflate Marx with official Marxism" (Hunt, 2004, p. 604). However, he admired the work of the pioneer school of western Marxism—-the Frankfurt School—and regretted that he had never had contact with their work during his studies in the 1950s: "If I had encountered the Frankfurt School while young, I would have been seduced to the point of doing nothing else in life but the job of commenting on them" (Foucault, 1991d pp. 120121).

It is noteworthy that Foucault opposed official Marxism in the form of Stalinism and the policies of the French Communist Party, but not the post-Marxist analysis of western Marxism as exemplified by the Frankfurt School from the 1930s on. As western Marxism thrived as an opposing discourse of official Marxism in the 1960s, the classical Marxist conception of ideology came into question in France, especially through the works of Foucault's early mentor, Louis Althusser. ${ }^{31}$ Foucault was enmeshed in this current within western Marxism, and this led him to make a "self-conscious attempt to avoid not just the [classical Marxist] concept of ideology, but the field designated by that concept" (Purvis \& Hunt, 1993, p. 488). In essence, he eschewed the classical Marxist conception of ideology, and replaced the concept of "ideology" with that of "political rationality".

\footnotetext{
${ }^{31}$ In 1981, Foucault revealed to his interviewer Ducci Trombadori: "I followed Louis Althusser, who worked militantly in the P.C.F. [French Communist Party]. It was also somewhat under his influence that I had decided to join. And when I left the party, he pronounced no anathemas, nor was it on that account that he decided to break off relations with me" (1991c, p. 55).
} 
As noted in chapter one, the notion of political rationality within governmentality studies refers to ways of thinking about and acting upon the social world. When political rationality is defined as a mode of thought, the Foucauldian view of political rationality is similar to the Gramscian post-Marxist conception of ideology as a "system of ideas" (see Hall, 1983; Purvis \& Hunt, 1993). What this means is that Foucauldian analysts of governmentality reject the classical Marxist conception of ideology, but their conception of political rationality is akin to post-Marxist thinking about ideology. In this sense, I find the post-Marxist approach to ideology espoused by critical frame analysts to be congruent with a global governmentality perspective. This dissertation uses the concepts of ideology and political rationality interchangeably in the epistemic genealogical study of ICT policies and news reports of the Daily Nation in chapters four and five, respectively.

This chapter has attempted to incorporate a global governmentality perspective into the conceptual framework of critical frame analysis. In doing so, the chapter has reconceptualized this research method to include Foucault alongside Gramsci. More importantly, the chapter has sought to integrate an epistemic genealogical worldview (emanating from a global governmentality perspective) with critical frame analysis. An epistemic genealogical study of East African communications transformations seeks to investigate the problematization of under-development of sub-Saharan Africa in relation to information and communication technologies. I adapt the core framing tasks of interpretive frame analysis as data-collection tools for this dissertation, but within a critical frame orientation. Hence, chapters four and five use diagnostic, prognostic and motivational data-collection tools to extract data on the framing of the ICT policies of the 
World Bank and East African governments as well as news reports on ICT in the Daily Nation of Kenya. 


\section{CHAPTER FOUR}

\section{AN EPISTEMIC GENEALOGY OF EAST AFRICAN COMMUNICATIONS TRANSFORMATIONS}

A critique is not a matter of saying that things are not right as they are. It is a matter of pointing out on what kinds of assumptions, what kinds of familiar, unchallenged, unconsidered modes of thought that practices that we accept rest. (Foucault, 1988, p. 154)

Liberal analysts of East African communications transformations hold that communication policy comprises constitutional provisions on individual and collective freedoms as well as legal and regulatory stipulations governing the print and broadcast media (Lederbogen, 1992; Boas, 2000; Moggi \& Tessier, 2001; Odhiambo, 2002; Ocitti, 2005). For example, from a liberal perspective, the communication policy of Kenya can be extracted from the Constitution of Kenya (Section 79), the Books and Newspapers Act (1962), the Official Secrets Act (1970), the Defamation Act (1972), and the Preservation of Public Security Act (1972), among other media-related laws. This legal thrust leads liberal analysts to adopt a research focus that seeks to identify legal loopholes that implicitly promote the contraction of media freedom. Moreover, liberal analysts take case law on media freedom emanating from constitutional courts as part of communication policy (see for example, Odhiambo, 2002; Ocitti, 2005).

A legal emphasis in the study of communication policies in relation to communications transformations is necessary in order to expand and safeguard media freedom. What needs to be done, though, is to expand the research area of communication policies in order to include not only the traditional mass media of print and broadcasting, but also ICT infrastructure and services. Most importantly, national communication policies can be viewed as instruments for entrenching economic 
globalization—especially as regards integrating a country's communications sector into the world economy. This is the position I take, and therefore I pay close attention to the epistemic dimension of East African communications transformations in relation to the World Bank's globalization frame of communications-related issues.

Drawing from an epistemic genealogical perspective, this chapter intends to show that East African ICT policies are implicated in economic globalization, and that they are formulated, primarily, to promote this global trend. While these policies talk about improving people's welfare, a genealogical study of their epistemic foundations reveals another story - that of the expansion of economic globalization.

The next section provides the sampling procedure used for this epistemic genealogical study of East African communications transformations. Thereafter, I analyze the World Bank's problematization of planned economy, the investment climate and the digital divide in relation to East African ICT policies. The other sections involve analysis of the framing of East African ICT policies, and identification of oppositional framing of these policies. I conclude this chapter by providing a critical frame perspective of the framing convergence on ICT issues between the World Bank and East African governments, and by commenting on the epistemic foundations of East African communications transformations.

\section{Sampling Procedure}

This study determines its sample using a judgmental sampling method within the nonprobability strand of sampling. In judgmental sampling, the researcher defines the criteria for inclusion and exclusion of possible units for the sample (Blaikie, 2000, p. 205). The 
range of the World Bank's media artifacts includes annual reports, issue-specific publications, website content, press releases and learning programs. The release of annual reports is central to the World Bank's practice of producing global information because these reports define the Bank's broader theme for a given year. Hence, annual reportsWorld Development Reports-form the main body of the Bank's global information to be reviewed in this study. Table 4.1 (overleaf) notes the titles of each report from 1990 to 2006- the period corresponding to the transformation of East African mediascapes (as described in chapter two).

How do I determine which World Development Reports are to be included in the sample for this study? First, I recap the World Bank's theoretical framework, and thereafter I revisit the official name of the World Bank. Finally, where an annual report devoted entirely to a key theme is lacking, I search for another World Bank publication that expounds on that theme.

The rationality, or ideology, of global neoliberalism synthesizes theories of liberal democracy and market economy. In line with the former theory, the Bank seeks to reform states, and through the latter, it focuses on transforming national economies. Hence, "state reform" and the transformation of "national economies," as well as assessment of the "investment climate" of individual countries, are fundamental to the Bank's version of global neoliberalism. These themes are covered in World Development Reports as follows: The State in a Changing World (1997) (state reform); Infrastructure for Development (1994) and From Plan to Market (1996) (economic reform); and A Better Investment for All (2005) (creation of favourable investment climates). 
Table 4. 1: World Development Reports (1990-2006)

\begin{tabular}{|l|l|}
\hline Year & Report Title \\
\hline 2006 & Equity and Development \\
2005 & A Better Investment Climate for All \\
2004 & Making Services Work for Poor People \\
2003 & Sustainable Development in a Dynamic World \\
2002 & Building Institutions for Market \\
$2000 / 2001$ & Attacking Poverty \\
$1999 / 2000$ & Entering the 21st Century: \\
1998 & The Changing Development Landscape \\
1997 & Knowledge for Development \\
1996 & The State in a Changing World \\
1995 & From Plan to Market \\
1994 & Workers in an Integrating World \\
1993 & Infrastructure for Development \\
1992 & Investing in Health \\
1991 & Development and Environment \\
1990 & The Challenge of Development \\
\hline
\end{tabular}


The Bank's official name-International Bank of Development and Reconstruction-directs attention to three main themes: international, development and reconstruction. The Bank regards itself as an "International" Bank, and as such, issues of economic globalization underpin the Bank's strand of global neoliberalism (see for example, Globalization, Growth and Poverty, 2002). Another aspect is that the Bank performs its operations in the name of "development," which makes economic development a significant component of its global information campaign. Thirdly, at the time of the Bank's inception, the theme of "reconstruction" emerged as a rallying call for rebuilding the national economies of European countries after the Second World War. Since the 1960 s, one of the major foci of the Bank has been the "reconstruction" of Africa in line with capitalist strategies of economic development. Currently, the Bank's project of "reconstructing" Africa is guided by the rationality/ideology of global neoliberalism (as noted in chapter two). One of the main strategies of this project is reforming public institutions with the aim of bringing them into conformity with the tenets of global neoliberalism.

Through privatization and liberalization of trade and markets, the Bank seeks to transform state-owned enterprises from public to private institutions. Caught in this transformation process are state-owned infrastructural enterprises such as telecommunications, electricity and water. Telecommunications play a central role in propelling the so-called "information revolution," as manifested in the upsurge of ICT and the interest generated by the G-7 countries and United Nations Economic Commission for Africa in seeking to create a "Global Information Society" and an "African Information Society," respectively. 
From the foregoing, it can be seen that the World Bank is involved in promoting development, economic reform, state reform, institutional reform, ICT, economic globalization, and favourable investment climates. These themes constitute the World Bank's version of global neoliberalism, and therefore I include in the sample those World Development Reports which cover them. Since 1990, seven annual reports stand out as concerned mainly with development: The Challenge of Development (1991), Development and Environment (1992), Infrastructure for Development (1994), Knowledge for Development (1998), Entering the 21st Century: The Changing Development Landscape (1999/2000), Sustainable Development in a Dynamic World (2003), and Equity and Development (2006). I have included the 1999/2000 and 1994 world development reports because the former is more comprehensive than others in terms of reflecting on the development theme during the 1990s, and the latter focuses more on infrastructure development, including the conceptual shift from public to private telecommunications services.

From Plan to Market (1996) and The State in a Changing World (1997) are the only reports devoted to economic and state reform, respectively; and Building Institutions for Market (2002a) and A Better Investment Climate for Everyone (2005) are the only ones promoting institutional reform and good investment climates. These four reports qualify for inclusion in the study sample because they deal with the stated themes. As for economic globalization and ICT, there is no single report that focuses entirely on them; hence, I have searched for issue-specific publications on both themes and included the following as part of the sample: Globalization, Growth and Poverty: Building an Inclusive World Economy (2002b), and Information and Communications Technologies: 
A World Bank Strategy (2002c). Out of a total of sixteen World Development Reports from 1990 to 2006, the sample captures eight themes represented by the units of analysis shown in Table 4.2 .

\section{Table 4. 2; Units of Analysis}

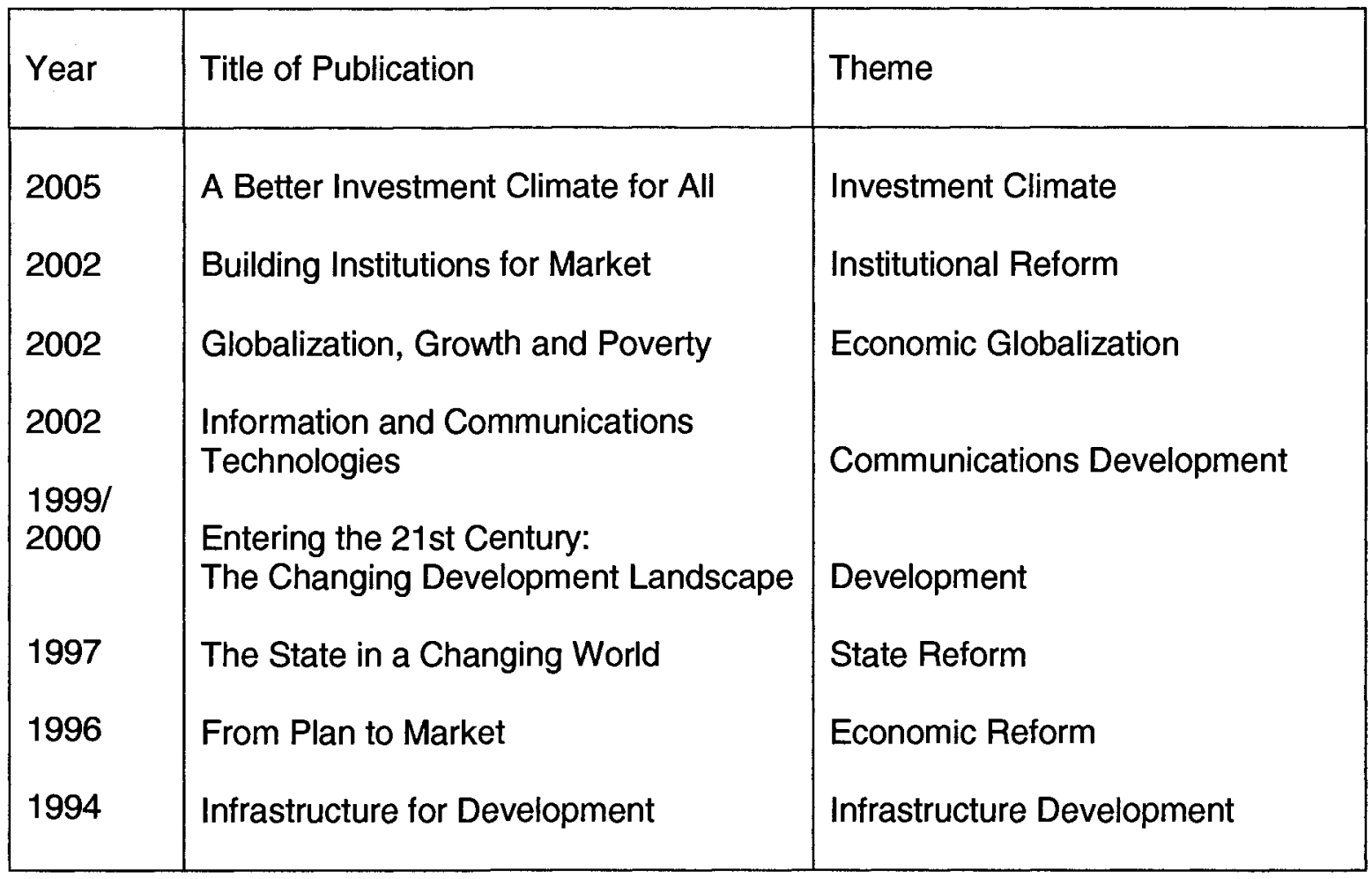

\section{Problematization of Planned Economy}

In chapter two, I have argued that East African countries-particularly Kenya and Tanzania-shifted from the political rationality of African socialism to that of global neoliberalism in the 1990s. This move was, essentially, a replacement of policies based on planned or mixed economy with the principles of market economy. In the communications sector, this shift entailed changing laws and formulating policies that support private provision of ICT services. These changes constitute the epistemic 
dimension of East African communications transformations, and they are guided by the knowledge form of global neoliberalism emanating from international development organizations. This section analyzes how the World Bank's problematization of planned economy has proceeded to encompass three epistemic shifts-from plan to market, planning to effective states, and public to market-supporting institutions. The significance of analyzing this problematization is that it underlies the framing of the World Bank's problematization of the investment climate and the digital divide, which in turn feed into the ICT policies of East African governments (as shown later in this chapter). Above all, these problematizations can be viewed as hindrances to economic globalization, and the prognostic framing of market economy, effective states and market-supporting institutions as contributing to the World Bank's globalization frame.

\section{From Plan to Market}

The World Bank observes in its 1996 World Development Report that experiments in planned economy have failed, completely, and that countries that had embraced socialism between 1917 and 1989 (when the Cold War ended), including Albania, Armenia, Croatia, the Czech Republic, Poland, Romania and Russia, are undergoing transition from planned to market economy. The Bank diagnoses the main problem of planned economy as that of giving primacy to industrial products over consumer goods: "Heavy industries such as machine building and metallurgy were emphasized, while development of consumer goods lagged" (1996, p. 2). According to the Bank, that emphasis brought about declining rates of economic growth, as the Soviet case demonstrates: "After posting high annual growth rates in the 1950 s (averaging 10 percent according to official 
estimates), the Soviet economy decelerated: growth averaged 7 percent per year in the 1960s, 5 percent in the 1970s, and barely 2 percent in the 1980 s, and in 1990 it contracted" (p. 2).

The plan-to-market transition envisioned by the Bank includes a shift from public to private ownership of property, from planned markets and trade to liberalization of markets and trade, and from nationalization to privatization, i.e., from state to private ownership of enterprises (pp. 1-6). Basically, the Bank's position on plan-to-market transition is that of the Washington Consensus (discussed in chapter one). What is significant, though, is that the 1996 World Development Report reinforces the earlier report of 1994 that sought to shift public opinion away from planned to market-based infrastructure services. This epistemic emphasis in the issue-area of infrastructure services, including telecommunications, has to be viewed within the context of the Bank's strategy to discredit all aspects of planned economy. As will be discussed later, this plan-to-market transition underpins the worldview on ICT shared between the Bank and East African governments.

\section{From Planning to Effective State}

In their diagnostic framing of various issues, all publications surveyed blame states for the prevalence of poverty. For example, the 1994 World Development Report notes about infrastructure services: "Governments—by confusing their roles as owners, regulators, and operators-have failed to improve service delivery" (p. 7). The World Bank's Globalization, Growth and Poverty (2002b) promulgates a similar message: blame states for poverty not (economic) globalization (pp. 26-28). The implication is that states that 
fail to implement trade liberalization and privatization have only themselves to blame: adopt globalization, reap prosperity; neglect globalization, risk marginalization (pp. 2 , 146).

According to the 1997 World Development Report, the main stumbling block to poverty reduction is inefficient states (pp. 1-2). The Bank defines states as "inefficient" if they are engaged in huge public expenditure, lack clearly-defined regulations on private investment, fund infrastructure services (instead of allowing private investors to do so), and turn a blind eye to corruption at the highest levels, among other factors (ibid.). The Bank offers a solution: shift from planning to market-enhancing states (pp. 2-15). It conceptualizes market-enhancing states as "effective," in contrast to planning states, which it regards as "ineffective," and proposes that effective states manifest two fundamental qualities, capability and effectiveness: "Capability...is the ability to undertake and promote collective actions efficiently—such as law and order, public health, and basic infrastructure; [and] effectiveness is a result of using the capacity to meet society's demand for those goods" (p. 3).

The World Bank's diagnostic framing of sub-Saharan African states is that they are experiencing a "crisis of statehood"-indeed, a "crisis of capability" (1997, p. 14). Its prognostic framing: sub-Saharan African states need "to separate the financing of infrastructure from its delivery, and to unbundle the competitive segments of utility markets from the monopoly segments" (p. 4). East African governments share this conception of the effective state with the World Bank, as demonstrated in their unbundling of state-owned telecommunications enterprises and the creation of national regulators (elaborated in chapter two). 


\section{From Public to Market-Supporting Institutions}

In its 2002 World Development Report, the World Bank's diagnostic framing blames states for rising transaction costs, which are "known to impede the development of markets through arbitrary exercise of state power, overtaxation, corruption, short time horizons, cronyism, and the inability to uphold public order" (p. 7). The Bank tacitly states its diagnostic and prognostic framing of this issue:

What limits market opportunities? Transaction costs from inadequate information, incomplete definition and enforcement of property rights, and barriers to entry for new participants. What increases them? Institutions that help manage risks from market exchange, increase efficiency, and raise returns. (p. 5)

The 2002 Report shifts emphasis from the concept of public institutions as instruments of enhancing human welfare to that of enablers of the accumulation of wealth (pp. 3-27). The Bank views "institutions" in three main ways, as "rules, enforcement mechanisms, and organizations" (p. 6). At the same time, it divides institutions into two key categories: "Corporate, collateral and bankruptcy laws are public institutions, as are the judiciary, tax collection agencies, and regulatory agencies," while "banks, reciprocity between community members, and land inheritance norms are private institutions" (p. 6). Institutions govern human behaviour, and they can be categorized as "formal" and "informal" (ibid.). For example, "public" institutions create "formal" institutions in the form of laws, regulations, and codes of conduct for public officials. "Informal" institutions are not codified into law or documented in regulations and codes of conduct; they are unwritten norms of conduct observed by members of a community in matters such as inheritance, marriage and faith. In this conceptualization of "institutions," national ICT policies can be regarded as "public" institutions which form the basis for creating "formal" institutions such as the regulatory agency of a national communications 
sector. An important aspect of the ICT policies of East African governments is that their epistemic thrust existed before their formulation. Indeed, the policies document a legal and regulatory orientation that has guided the national communications sector since the 1990s.

\section{Problematization of the Investment Climate}

To entrench market economy in national policies, including those of ICT, the World Bank engages in problematization of the investment climate. For instance, the World Bank asserts in its 2005 World Development Report: "A good investment climate provides opportunities for people to better themselves, and [thus] improving the investment climate is the first pillar of the World Bank's overall development strategy" (p. 2). This commitment reveals that enhancement of the investment climate in all sectors of a national economy is the Bank's underlying motive in its policy interventions in developing countries. The following analysis seeks to establish that creation of a good investment climate in national communications sectors permeates East African ICT policies, and that their problematization of the investment climate corresponds to that of the World Bank.

\section{Diagnostic Framing}

The Bank's diagnostic framing of the investment climate is that governments, more often than not, fail to create a conducive investment climate $(2005$, pp. 4,19$)$. The Bank criticizes governments because their policies and officials' actions generate "costs, risks and barriers to competition" that establish unfavourable conditions for investment (p. 4). 
It argues that firms doing business in developing countries can face prohibitive costs due to high taxes, slow licensing processes, delayed judicial process in the enforcement of contracts and property rights, underdeveloped infrastructure, corruption, and lack of security, among other factors (ibid.). The Bank also postulates that firms are at risk in countries that lack clearly-defined property rights, predictable outcomes of regulations, equal treatment of all firms without favour, and stable policy positions on particular sectors of their national economy (p. 5). It notes that "policy-related risks are the main concern of firms in developing countries," and adds that curtailment of competition militates against a favourable investment climate because "barriers to competition that benefit some firms deny opportunities and raise costs for other firms and for consumers" (ibid.). Within this diagnostic framing, the Bank expects East African governments to eradicate policy-related risks in their national communications sectors.

\section{Prognostic Framing}

To overcome unnecessary costs and risks to firms as well as insufficient market competition within various sectors of national economies, the World Bank offers this prognosis: "The key message: for governments at all levels, a top priority should be to improve the investment climates of their societies" (p. 20). The Bank expects that its prognostic framing of the investment climate will make governments devote more attention to firms-the catalysts of economic development and poverty reduction (p. 2). It asserts that this perspective will encourage governments to create conditions for enhancement of their countries' investment climates, given the fact that "firms assess 
investment opportunities and related government policies and behaviours" before making any investment decisions (ibid.).

\section{Motivational Framing}

To reinforce its prognostic framing of the investment climate, the World Bank engages in motivational framing: "A good investment climate provides opportunities and incentives for firms - from microenterprises to multinationals - to invest productively, create jobs and expand" (p. 1). In any case, it argues, "Improving the investment climates of their societies is critical for governments in the developing world, where 1.2 billion people survive on less than $\$ 1$ a day, where youths have more than doubled the average unemployment rate, and where populations are growing rapidly" (ibid.). The Bank, then, holds that developing countries intent on tackling underdevelopment have no other option than to improve their investment climates for firms.

The World Bank's problematization of the investment climate has shaped the general framing of ICT issues by East African governments. On its part, the Kenyan government proclaims that it is committed to creating "an enabling environment for Public-Private Partnerships (PPP) in ICT development" (2006a, p. 6), and that one of its main overall strategies for ICT development is "to create a favourable investment climate" (p. 14). A similar message is stated in the Tanzanian government's Policy Objective 3.6.2 (c), which aims to "create a favourable climate for industry, business and investment to adopt ICT solution [sic]" (2003, p. 16).

Furthermore, in ICT Policy Statement 3.5.4 (1), Tanzania promises to deal with policy-related risks: "The government will review existing laws and regulations in order 
to repeal or adjust those that are not conducive to the healthy growth of the ICT industry and enact new ones that take account of issues associated with Internet governance and the convergence of telecommunications, broadcasting and information systems" (2003, pp. 16-17). In a similar vein, the Ugandan government affirms that there is "need for a framework that can guide and direct inward investment in a manner that is desirable for the country and attractive to prospective investors and which harness all possible resources" (2003, p. 10, see also p. 33). To "provide regulatory certainty to investors," Uganda plans to harmonize its legal and regulatory framework for ICT with those of international bodies, such as the World Intellectual Properties Organization and the International Telecommunication Union. (p. 39).

\section{Problematization of the Digital Divide}

In its problematization of the digital divide, the World Bank argues that this gap in technological adoption militates against the integration of national economies into the world economy. Indeed, the digital divide is a hindrance to economic globalization. The Bank proposes private provision of ICT services as the main strategy for overcoming the digital divide. Moreover, it claims, this strategy will bring about enhancement of economic development. I seek to demonstrate in this section that the World Bank's problematization of the digital divide-through diagnostic, prognostic and motivational framing-underpin East African ICT policies.

\section{Diagnostic Framing: The Widening Digital Divide}

The World Bank identifies the widening "digital divide" between the developed and developing worlds, and within countries, as the main problem hindering developing 
countries from integrating more readily into the world economy. This divide diminishes the prospects of technological adoptions that would accelerate development in the global South. As such, the Bank's diagnostic framing of ICT in the 2002 strategy document focuses on the growing digital divide:

Growth in the use of information infrastructure in developing countries during the 1990s has been impressive but inequitable among and within countries. While the gap in fixed and mobile telecommunication has narrowed, a 'digital divide' has emerged in more advanced information infrastructure and is still growing. (2002c, p. vii)

Like the World Bank, East African governments find the digital divide to be the core problem, and they hold that appropriate ICT policies can solve it within each jurisdiction. The wording of Kenya's diagnostic framing of the problem has striking semblance to that of the World Bank:

The Government recognizes that there is a growing digital divide between the countries that are highly endowed and developed in the field of information technology and Kenya as well as between rural and urban areas in the country. It is, therefore, the objective of the Government to initiate steps to reduce this divide by using information technology to rapidly develop all sectors of the economy. (p. 9)

Tanzanians also admit the digital divide exists among and within nations, and they assert that bridging it will transform Tanzania into a knowledge-based economy. Their policy explicitly states:

The current Tanzania ICT situation requires urgent steps to enable Tanzanians to participate meaningfully in the knowledge economy.... The dangers posed by the digital divide, and the risk of being excluded further from the knowledge economy and social development, has propelled the Government to put in place a policy framework through which coordinating mechanisms and harmonized strategies might be nurtured. (p. 1)

The Ugandan policy notes that the International Development Research Centre, ${ }^{32}$ through its 1998 study, established the existence of a digital divide which was reflected in 
ICTs being "concentrated in urban areas, especially around [the capital city] of Kampala" (p. 7). It further observes that lack of expansive infrastructure and inadequate maintenance contributes to the acceleration of the divide. Hence, the government offers "an ICT Policy Framework to meet the challenges and the harnessing of the underlying potentials and opportunities" of information and communications technologies (ibid.).

The issue of the digital divide in ICT infrastructure and application is central to the World Bank's diagnostic framing and that of the governments of Kenya, Tanzania and Uganda. This meeting of minds reveals the existence of a shared source of development knowledge, or rather, neoliberal development knowledge; indeed, their diagnostic framing of ICT policies proves their convergence on ICT issues.

\section{Prognostic Framing: The Private Provision of ICT Services}

The 1994 World Development Report insists that nation-states should move away from public to private provision of telecommunications services (pp. 8-10, 109-122). Its guiding principle is that telecommunications services are "private" rather than "public" goods. Private goods are "'rival' (consumption by one user reduces the supply available to others) and 'excludable' (a user can be prevented from consuming them)" (p. 23). Although the World Bank asserts that "many infrastructure services are almost (although not perfectly) private goods" (ibid.), to the Bank, telecommunications services are rival and excludable, and as such, they fall under the category of private goods along with rail, airport services and local power distribution (World Bank, 1994b, 1997). Figure 4.1 illustrates the Bank's conception of telecommunications services as private goods-i.e., as "rival" and "excludable".

\footnotetext{
${ }^{32}$ The International Development Research Centre is a Canadian Crown Corporation.
} 


\section{Figure 4.1 World Bank's Conception of Infrastructure Services}

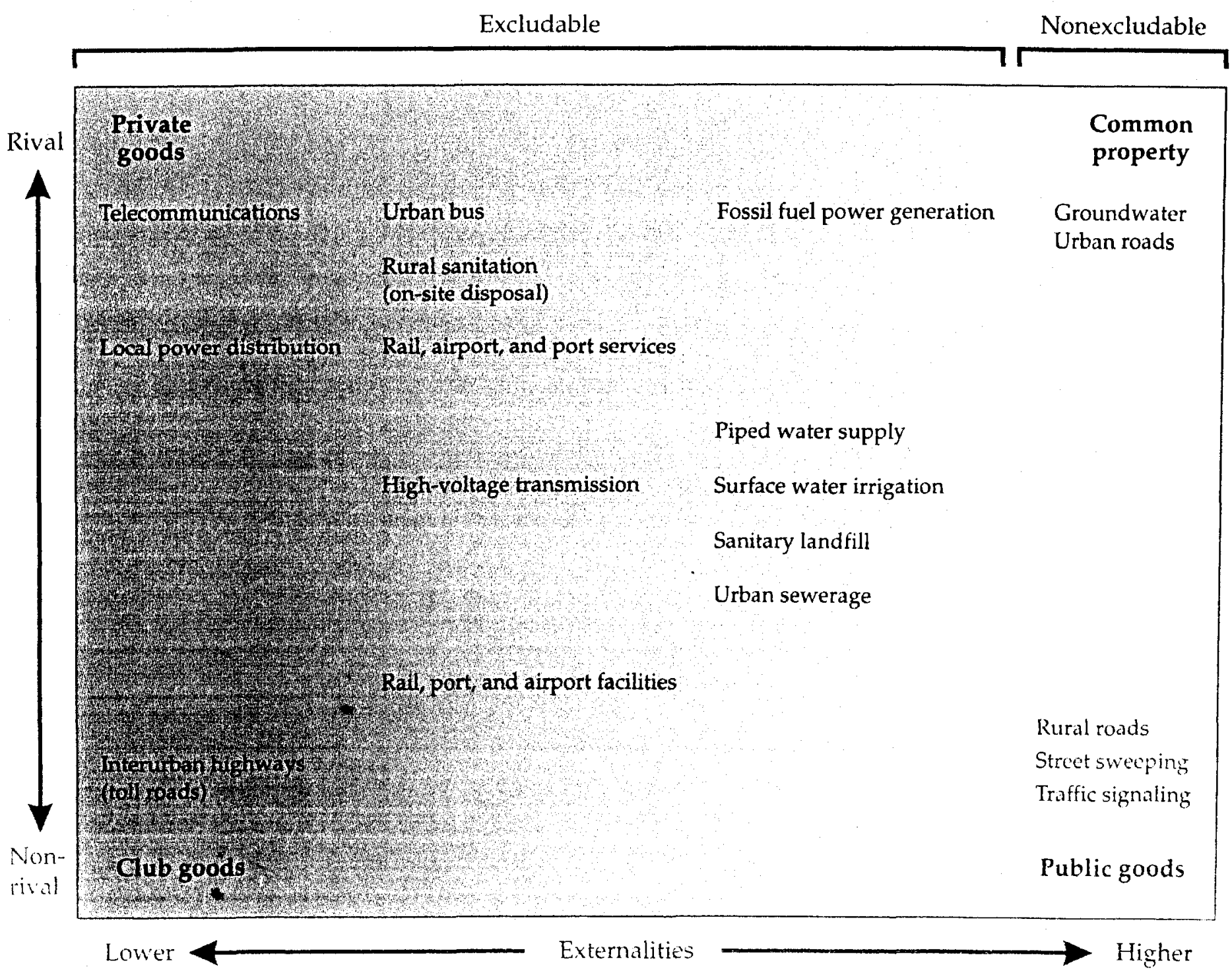

Note: Excludable means that a user can be prevented from consuming the good or service. Rival means that consumption by one user reduces the supply available to other users.

Source: $\quad$ World Development Report (World Bank, 1994, p. 25) 
This prognostic and epistemic emphasis brings to the fore the World Bank's position on telecommunications and ICT: developing countries have to nurture private investment (ibid.). In its 2002 strategy publication, the World Bank reiterates its commitment to private ICT investment:

The World Bank promotes increased competition and private participation in the II [Information Infrastructure] sector by supporting the entry of new service providers, privatization of state enterprises, and more generally, by creating conditions that attract direct, private investment, and facilitate access to domestic and foreign capital markets. (p. 44).

It follows, then, from the preceding discussion that the World Bank's prognosis for the digital divide is the strategy of unleashing private investment in telecommunications services (2002b, pp. 43-49). This prognostic framing of the private provision of telecommunications services as the best solution for resolving the digital divide guides the national ICT policies of Kenya, Tanzania and Uganda.

The Kenyan government declares that it will seek to develop private ownership of ICT services (2006a, pp. 3, 4, 6, 10, 19, 25-27). For example, in the area of telecommunications, "The government will adopt the following strategies to achieve the above policy objectives: promote competition, increase customer choice and accelerate investment through liberalization of the sector and the licensing of new players in the various telecommunications market segments" (p. 25).

Similarly, the Tanzanian government asserts: "It is obvious that the development of ICT cannot occur without the involvement of the private sector" $(2003$, p. 12). It attributes the advancement of ICT in Tanzania to "government reforms, privatization, telecommunications sector liberalization, the emerging private sector and entrepreneurship, and official development assistance" (p. 6). Finally, in Policy Objective 
(f), the Tanzanian government commits itself to enhancing "a favourable environment for cooperation and partnership in ICT among public and private sectors, civil society, and between all stakeholders at local, national, regional and international levels" (p. 9).

The Ugandan government's prognostic framing of ICT issue is similar to that of the World Bank and its neighbours, Kenya and Tanzania. In its Policy Objective 4.2 (d), the government declares that its intentions are to "promote fair competition and private investment in the ICT sector with particular emphasis on development and encouragement of local participation including specific incentives for investing in ICT" (2003, p. 32). It emphasizes public-private partnership as the key that can open up ICT development in Uganda (p. 35).

The broad prognostic framing of the World Bank corresponds to that of the governments of Kenya, Tanzania and Uganda. The central issue is that the digital divide can be resolved through enhancing opportunities for private investment in ICT infrastructure. Emphasis on private provision of ICT services means a prognostic and epistemic shift from planned to market-based infrastructure services. This shift permeates East African ICT policies, and as demonstrated in this section, it can be traced back to the World Bank's 1994 World Development Report.

\section{Motivational Framing: ICTs Enhance Economic Development}

What has motivated the World Bank to devote an entire issue-specific publication to ICTs? The answer to this question boils down to determining the World Bank's motivational framing of ICTs. The 2002 strategy document insists that ICTs are the prime movers of economic development: "Indeed information and communication technologies 
are key to economic development and growth; offer opportunities for global integration while retaining the identity of traditional societies; can increase the economic and social well-being of poor people and empower individuals and communities; and enhance the effectiveness, efficiency, and transparency of the public sector (including the delivery of social services)" (p. vii).

As part of their vision, East African governments promise that ICT will enhance national efforts to bring about more development. Kenyans hope their policy will contribute to the creation of "a prosperous ICT-driven Kenyan society" in that it seeks "to improve the livelihood of Kenyans by ensuring the availability of accessible, efficient, reliable and affordable ICT services" (p. 1). Tanzanians expect the new policy will "enhance nationwide economic growth and social progress" and "provide a national framework that will enable ICT to contribute towards achieving national development goals" (pp. 2, 9). On their part, Ugandans envision "a Uganda where national development, especially human development and good governance, shall be sustainably [sic] enhanced, promoted and accelerated by efficient application and use of ICT, including timely access to information" (p. 32).

The motivational framing of ICT as one of the main catalysts of economic development is dominant in the World Bank's strategy document as well as in East African ICT policies. The parties concerned converge on the primacy of ICT in national economic development, and as such, they share the same motivational framing of ICT issues. 


\section{Framing East African ICT Policies}

The preceding epistemic genealogical study has found that the World Bank's set of three problematizations (planned economy, the investment climate and the digital divide) is shared by East African governments in the issue-area of ICT. This framing convergence on aspects of problematizations related to ICT indicates that the World Bank, among other international development organizations, has contributed to the epistemic basis of East African communications transformations. This section shifts from reconstructing the problematization of ICT issues to analyzing the framing of East African ICT policies, with special reference to the World Bank's "good policy" guidelines. I provide the framing scope of national ICT policies, and thereafter present their prognostic framing.

\section{The Framing Scope}

The World Bank defines the scope of the ICT sector as comprising telecommunications, broadcasting, information technologies and postal services:

The Information and Communication Technologies Sector covers ... . telecommunications and broadcasting sectors, as well as information technologies. For the purposes of this strategy paper, it also includes postal services. (2002b, p. 3)

The scope of the Kenyan policy coincides with that of the World Bank: part three covers information technology; parts four and seven, broadcasting; and parts five and six, telecommunications and postal services, respectively. The Tanzanian policy is mainly on information technology, but it contains scattered highlights on telecommunications (2.1.1, 2.6, 3.10.4), broadcasting (specifically, technological convergence, 2.1.1, 3.2.1, 3.5.3, 3.9.1, 3.9.2, 3.9.3, 3.9.4), and postal services (3.7.3.xi). Under "communication infrastructure" (part 3), Uganda takes stock of on-going changes in broadcasting (3.3.1); 
print media (3.3.2); film and video production (3.3.2); theatre (3.3.2); libraries, archives and documentation centres (3.3.2), local-central government flow of information (3.3.3); and indigenous and traditional communication (3.3.4). The Ugandan policy also has sections on information technology $(3.4,3.5,3.6,3.7)$, and telecommunications (3.2). Not only does the World Bank (2002c) provide the framing scope of national ICT policies, it prescribes "good policy practices" that promote private provision of ICT services. The practices include: no public funding, enhancement of competition, separation of regulator from operators, extension of ICT to rural areas, leading by example, promotion of e-commerce, development of human resources, and restraint in establishing an ICT ministry. I analyze each of the practices in relation to national ICT policies.

\section{Good Policy Practices}

In this section, I adopt a Foucauldian conception of "critique" that deviates from conventional thinking that regards the art of critique as comprising the presentation of arguments that counter others. Foucault insisted that critique can be viewed as a strategy for "pointing out on what kinds of assumptions, what kinds of familiar, unchallenged, unconsidered modes of thought that practices that we accept rest" (Foucault, 1988, p. 154). In this regard, the following discussion seeks to trace taken-for-granted issues in East African ICT policies to the World Bank's framing of "good" ICT policy practices. Thus, the focus is on the framing of East African ICT policies and not the evaluation of various policy positions from the standpoint of their validity. 
No Public Funding: The World Bank discredited public funding of telecommunications in its 1994 World Development Report: "Infrastructure investments have often been misallocated-too much to new investment, not enough to maintenance; too much to low-priority projects, not enough to essential services" (p. 4). The Bank's ICT strategy publication reiterates this position by stating: "The World Bank Group . . . advises against the use of scarce [public] funds for investment in this [ICT] sector" (2002c, p. 45). This prognostic framing of ICT funding is reflected in East African ICT policies. None of the countries surveyed—Kenya, Tanzania and Uganda—indicate that they intend to use public finances to fund ICT services. Instead, they seek to entrench private investment in that sector. Abstaining from public funding of the ICT sector is another area where the World Bank's ICT policy converges with that of the governments of Kenya, Tanzania, and Uganda.

Enhancement of Competition: Central to private investment is the principle of fair competition within a particular sector. Hence, the World Bank declares that it "promotes increased competition and private participation in the II [Information Infrastructure] sector by supporting the entry of new service providers, privatization of state enterprises, and more generally, by creating conditions that attract direct, private investment, and facilitate access to domestic and foreign capital markets" (2002c, p. 44).

According to the Bank, good policy practice has to enhance competition among various players in the ICT sector. This assertion is adhered to religiously by East African governments. For example, the Kenyan government declares that it will "promote competition, increase customer choice and accelerate investment through liberalization of 
the sector and the licensing of new players in the various telecommunications market segments" (p. 25). The Tanzanian government credits the expansion of ICT to its implementation of liberalization and privatization policies, which enhance competition (p. 6). Finally, the Ugandan government affirms in its Policy Objective 4.2(d) that it will "promote fair competition and private investment in the ICT sector" (p. 32). East African governments agree with the World Bank that their primary task is to encourage competition and private investment in the provision of ICT services.

Separation of Regulator from Operators: The prognostic framing of the 1994 World Development Report lays the foundation on which the World Bank advises developing countries to separate state-owned telecommunications enterprises into distinct corporate entities, and also form a regulatory agency (pp. 52-72). In its 2002 ICT strategy publication, the Bank insists that governments should have a regulator that is not entangled in the business of providing ICT services (p. 44). A national regulator is expected to facilitate "licensing, numbering, interconnection and access (ensuring fair competition), protection of consumers, monitoring of operators, and settlement of disputes" (ibid.). A regulator also deals with assigning broadcast frequencies, and generally has oversight over radio and television transmission as well as postal services (ibid.).

Kenya, Tanzania and Uganda have already gone through the process of separating the national regulator from the ICT operators. What is interesting about their ICT policy documents is that they are framed as though the three countries were making a progress report on this issue. For example, the Kenyan government has this to say: "In 1997, the 
government released the Telecommunications and Postal Sector Policy Guidelines that created an environment for competition in several market segments and paved [the] way to ... enactment of the Kenya Communications Act of 1998 which repealed the Kenya Posts and Telecommunications Act and established: (a) CCK [Communications Commission of Kenya] as the telecommunications, radio communications and postal regulator; (b) National Communications Secretariat (NCS) to serve as a policy advisory body; (c) Communications Appeals Tribunal; (d) Telkom Kenya Limited; and (e) Postal Corporation of Kenya" (2006a, p. 3).

The Tanzanian and Ugandan governments also account for the separation of their state-owned telecommunications enterprises (Government of Tanzania, 2003, pp. 6-7; Government of Uganda, 2003, p. 15). The separation policy confirms that East African governments followed the World Bank's prognostic framing of the separation of regulator from operators.

Extension of ICT to Rural Areas: The World Bank admits that market liberalization and privatization do not generate uniform expansion of ICT infrastructure and services in both urban and rural areas (2002c, p. 45). In fact, the trend is that ICTs are concentrated in urban areas (Government of Kenya, 2006; Government of Tanzania, 2003; Government of Uganda, 2003). In order to expand ICT access in rural areas, the World Bank advises governments to grant contracts to companies "asking for the lowest subsidy" (2002b, p. 45). However, there is a caveat: "The successful roll-out of such schemes would normally require that the market has already been effectively liberalized and that no operators have offered to provide the services on commercial terms" (ibid.). 
In line with the World Bank's position of offering subsidies to private investors interested in ICT expansion in rural areas, East African governments plan to establish a fund for that. Kenyans call it the Universal Service Fund; Tanzanians, the Rural Telecommunication Development Fund; and Ugandans, the Rural Communications Development Policy.

Leading by Example: The World Bank advises government officials: "Governments can promote the widespread diffusion of ICT applications and promote the idea of a knowledge economy only if their own operations are streamlined and technologyenabled" (2002b, p. 48). East African governments follow this advice by establishing website presence and committing themselves to improving e-government services (Government of Kenya, 2006, p. 6; Government of Tanzania, 2003, p. 19; Government of Uganda, 2003, pp. 36-37). Tanzanian Policy Objective 3.8.2(b) illustrates this point precisely: the government seeks to "empower the public by building an e-government platform that facilitates their relationship and interactions with the government, and enhances the range and delivery of more efficient public services at both central and local levels" (p. 19).

Promotion of e-commerce: The World Bank labels e-commerce "the linchpin of the new economy" and maintains that e-commerce enhances trade between countries and offers prospects for expanded markets (2002c, p. 47). As such, it argues that e-commerce is placing countries in better economic standing within the "new" world economy. East African governments uphold the e-commerce prognostic frame by promising to 
accelerate the development of e-commerce (Government of Kenya, 2006, p. 11;

Government of Tanzania, 2003, p. 16; Government of Uganda, 2003, p. 1). For instance, the Kenyan government plans to implement the following strategies: "(a) support the development of e-commerce by enacting appropriate legislation to support e-business; (b) support promotional campaigns to raise public awareness on the potential opportunities presented by e-commerce; and (c) promote collaboration with the international community in developing an equitable framework for e-commerce" (p. 11).

Development of Human Resources: The World Bank recommends that governments facilitate the acquisition of ICT skills at all levels of education (2002c, p. 49), and offers two main reasons why governments should pay close attention to ICT skills training: to produce a sufficient labor force for the ICT sector; and to speed up the adoption process of ICT technology (ibid.). This theme is clearly central to East African governments because they seek to introduce ICT skills training in primary and high schools as well as technical training institutions and universities (Government of Kenya, 2006, p. 5; Government of Tanzania, 2003, p. 14; Government of Uganda, 2003, p. 33).

Restraint in Establishing an ICT Ministry: The World Bank is against establishing a ministry of ICT (2002c, p. 49). In support of this prescriptive framing of an ICT issue, the Bank argues that having an autonomous ICT ministry can add an unnecessary bureaucratic burden to governments (ibid.). The Bank's solution is that the ICT sector can be managed through existing and inter-ministerial structures (ibid.). This advice finds a home in East African ICT policies, and although Uganda formed its Ministry of 
Information and Communication Technology in 2006, Kenya and Tanzania have no such plans (Government of Kenya, 2006, pp. 47-49; Government of Tanzania, 2003, p. 23). Instead, they seek to utilize existing and joint institutional arrangements. Kenya prefers to rely on its already-functioning National Communications Secretariat to coordinate ICT issues, while Tanzanians expect the coordination of all ministries in the implementation of ICT policies.

The World Bank's prescriptions of good ICT policy practices, as described above, can be situated within its international development project of creating an African information society as part of the envisioned global information society. Indeed, the Bank premises its prognostic framing of national ICT policies on the assertion that ICT can help "create an information society" at the national and global levels (2002c, p. 46). Such a national and global society depends on the efficient flow of information through the delivery systems of the Internet, broadcasting, print media and postal services as well as the application of ICT to solving development problems (pp. 2-6, 21). The Bank argues that information delivery systems and ICT application can enhance economic development: "Countries that had more telephones—or higher teledensity—than one would expect given their 1980 income levels, saw higher [economic] growth rates between 1980 and 1998 than those with relatively low teledensity" (p. 6).

East African ICT policies reflect the basic principle of the World Bank's prognostic framing of national ICT policies: the state is to facilitate the creation of a national and global information society. The Kenyan government seeks to mold "a new society based on information and knowledge" and to enable the incorporation of "Kenya into the global economy" (pp. 9, 11). The Tanzanian government aims to "transform 
Tanzania into a knowledge-based society through the application of ICT" (p. 9). And the Ugandan government strives to "develop the necessary policies that provide for preparation and transition to a knowledge-based economy" (p. 40).

This section has attempted to provide evidence to the effect that the framing of East African ICT policies corresponds to the World Bank's prognostic framing of ICT issues. East African governments operate within the Bank's framing scope and the general project of establishing a national, regional and global information society.

Moreover, the surveyed governments stick to the Bank's prescription of good ICT policy practices. These findings indicate that East African governments derive knowledgeforms on ICT from the World Bank (among other international development organizations). Hence, this epistemic genealogical study contributes to the view that the Bank is instrumental in shaping the body of knowledge underpinning on-going changes in East African mediascapes.

\section{Oppositional Framing: The Threat to Cultural Sovereignty}

The World Bank's 1999/2000 World Development Report, Entering the 21st Century, highlights the need for developing countries to harness globalization because it has the potential to open worldwide markets and disseminate technological know-how (p. 4). However, many anxieties surround this process, such as the retrenchment of workers occasioned by the increased import of cheap goods and services (ibid.). The anxiety about media content is a major one, as reflected in East African ICT policies. Indeed, it forms the basis of an oppositional framing of ICT issues despite the World Bank's push for more economic globalization. East Africans are seeking to reclaim their "cultural 
sovereignty"-an emerging counter-framing strategy for dealing with ICT issues. Leslie Regan Shade defines cultural sovereignty as "the ability of a country to enact laws and policies that protect and promote its culture and cultural industries" (2006, p. 346).

Tanzanians view the influx of foreign media content as one of the main threats to the cultural sovereignty of developing countries (p. 20). They use the metaphor of "invasion" to underscore their diagnostic framing of this threat: "Developing countries are being invaded by foreign ideas and values that may undermine or overwhelm local cultural heritage and economic livelihood" (ibid.). To overcome the immanent threat to cultural sovereignty, Tanzanians declare, "foreign content must be matched by the expression, collection and dissemination of local knowledge and content that is relevant to local situations" (ibid.). The Tanzanian prognostic framing of cultural threat is that the government should "encourage the wider use of Kiswahili [a common language in East Africa] in developing local content in order to promote local culture, [and] attract local end users as well as the Tanzanian diaspora" (p. 21).

In their concern about cultural sovereignty, Ugandans plan to introduce a quota system of required local content to counter the large incoming volume of foreign media content (p. 37). They also seek to "develop and exploit local talents of folk performers, which will contribute to local programming for community radio services as well as preservation of cultural values" (p. 38). Kenyans also have joined their neighbours in supporting the protection of cultural sovereignty. Their diagnostic framing of the threat to cultural sovereignty emphasizes the dearth of local media content in developing countries (p. 7). They insist that only a commitment to the creation of local content can save Kenya and other developing countries from being overwhelmed by foreign content (ibid.). 
Despite the seemingly overwhelming efforts of the World Bank in entrenching economic globalization and neoliberal globalism in the global South, sparks of resistance are evident in policies formulated by East African governments. However, promotion of cultural sovereignty faces the major challenge of coming to terms with the rationalities of economic globalization and global neoliberalism, which promote trade liberalization. By committing themselves to neoliberal policies of privatization and liberalization of trade and markets, East African governments have, in effect, accepted the efficacy of economic globalization and global neoliberalism.

\section{A Critical Frame Perspective of Findings}

Using Gramscian and Foucauldian epistemologies, this section interprets the above findings from a critical frame perspective. It covers four main aspects of the two epistemologies: hegemonic framing, national-popular rationality and ideology, the power/knowledge thesis, and the automatic functioning of power.

\section{Hegemonic Framing}

A critical frame perspective conceptualizes "framing convergence" as "hegemonic framing." From Stuart Hall's (1977b, 1982) application of Gramscian epistemology, hegemonic framing can be defined as a strategy of articulating particular "definitions of the situation" that privilege some issues over others in public debates, policy-making processes and so on. Through diagnostic, prognostic and motivational analysis of East African ICT policies, I have discovered the presence of hegemonic framing which is founded on "definitions of the situation" prescribed by the World Bank. This finding leads to the conclusion that global neoliberalism was the guiding rationality (and 
ideology) in the formulation of the ICT policies of Kenya, Tanzania and Uganda. Subsequently, global neolibealism underpins the on-going transformations of East African mediascapes.

\section{National-Popular Rationality/Ideology}

Gramsci focused on studying the entrenchment of hegemony within a nation-state, and argued that the task of emancipatory agents is to transform an ideology into nationalpopular common sense. However, the World Bank has assumed the role of performing a passive revolution through its work of making global neoliberalism a global-popular common sense. This claim is supported by the Bank's problematization of planned economy, and its insistence on the efficacy of market-based national economy. In turn, the problematization of planned economy leads to problematization of the investment climate and the digital divide. This chapter has sought to show that this set of three problematizations forms the basis of East African governments' framing of their national ICT policies. As such, East African governments are converting global neoliberalism from a global-popular to a national-popular rationality/ideology. In this sense, then, East African governments are carrying out the ideological work of the World Bank, and using the knowledge-form emanating from this exercise to transform their national communications sector. Global neoliberalism benefits local and transnational investors as governments liberalize and privatize state-owned enterprises: 


\section{The Power/Knowledge Thesis}

"Receptacles of problematization"-policy documents and publications-analyzed in this chapter can be interpreted through Foucault's thesis of power/knowledge. The World Bank's and East African governments' "receptacles of problematization" privilege global neoliberalism, a knowledge-form (re)produced within an established context of power relations. Chapter one of this dissertation states Foucault's power/ knowledge thesis: "There is no power relation without the correlative constitution of a field of knowledge, nor any knowledge that does not presuppose and constitute at the same time power relations" (1977, p. 27). The World Bank articulates global neoliberalism as its core form of knowledge, and thus its media products and consultancy services are embedded in this knowledge context. The Bank does not offer this knowledge in a vacuum; it operates within a power relation of a particular type- - that of neoliberal global governance. The permeation of the World Bank's hegemonic framing of ICT issues in East African ICT policies indicates not only the presence but also the expansive reach of neoliberal global governance. This power relation drives the on-going transformation of East African mediascapes.

\section{The Automatic Functioning of Power}

Neoliberal global governance can be viewed from a Foucauldian worldview as a form of "disciplinary power." Foucault used the panopticon metaphor to underscore the practice of "surveillance" that possessors of disciplinary power exercise over their subjects at all times (1977, pp. 195-228; see also, Gill, 2003, pp. 135, 182-183). Aspects of this practice include physical observance of inmates, patients and workers, and collection of data from 
these individuals. Possessors of disciplinary power use the forms of knowledge emerging from analysis of collected data and theorizing to perfect their strategies of surveillance over their subjects. Their aim is to intensify surveillance to the highest level so that individuals will self-regulate their behaviour without supervision from the possessors of disciplinary power. Foucault argued that this "automatic functioning of power" could bring about a "disciplinary society."

Drawing on a Foucauldian epistemology, I make the following observation about the World Bank's hegemonic framing and its permeation in East African ICT policies. The World Bank has exercised surveillance over East African countries to the point that it has created a state of "automatic functioning of power." This situation has come about through the Bank's collection and analysis of data on sub-Saharan Africa and resultant theorizing, and its expectation that governments will implement these findings through political and economic reforms. Hence, the framing convergence between the World Bank and East African ICT policies creates a climate conducive to the "automatic functioning of power".

\section{Governing the Epistemic Foundations}

This chapter has studied the epistemic dimension of East African communications transformations through the application of an epistemic genealogical perspective and utilization of a particular research method-critical frame analysis. As an epistemic genealogical study, the chapter has discovered a set of three problematizations that hinder economic globalization-planned economy, the investment climate and the digital divide - underpinning the World Bank's framing of ICT issues. The Chapter has 
attempted to establish that these problematizations are at the heart of the ICT policies of East African governments as well as the epistemic foundations of East African communications transformations. This finding leads to the observation that the World Bank has played a significant role in entrenching economic globalization in East Africaespecially through its problematization and framing of ICT-related issues.

This chapter has sought to show that the epistemic aspect of economic globalization_-global neoliberalism—forms the conceptual basis of ICT policy documents produced by the World Bank and East African governments. What this means is that knowledge and international development organizations matter in spreading economic globalization. Knowledge matters, too, in the study of East African communications transformations. This epistemic genealogical study has tried to show that the epistemic foundations of current changes in East African mediascapes emanate from global neoliberalism-a knowledge-form whose main purpose is to promote economic globalization. This chapter shows that the framing thrust of East African ICT policies gives primacy to entrenching economic globalization in national communications sectors. The next chapter examines the problematization of ICT issues in media reports in relation to global neoliberalism and economic globalization. 


\section{CHAPTER FIVE}

\section{AN EPISTEMIC GENEALOGY OF ICT NEWS IN KENYA}

In periods of major social restructuring there is an intersection of diverse economic, political and sociocultural narratives that seek to give meaning to current problems by constituting them in terms of past failures and future possibilities. Different social forces in the private and public domains propose new visions, projects, programmes, and policies. (Jessop, 2002, p. 92)

The previous chapter has identified the oppositional framing of cultural sovereignty as East African governments' main form of resistance to neoliberal world order within the context of ICT issues. The aims of this chapter are twofold: to determine the presence or absence of resistance to neoliberal world order, and to explain the presence or absence of such resistance. To pursue the first goal, the chapter seeks to answer the question, To what extent are mainstream East African newspapers implicated in the enhancement of neoliberal world order? The assumption is that resistance is a public practice in the sense that demonstrations and rallies by civil society organizations are open to the media and the general public. Analyzing media content, then, is one of the ways in which media analysts can find out whether East African newspapers are incorporating alternative voices of civil society organizations when reporting ICT issues.

The chapter finds that reportage on ICT related activities of civil society organizations in East African newspapers is minimal, and thus it follows the second goal by asking: Why do East African newspapers sideline civil society organizations? Thus it investigates the reasons behind the absence of resistance to neoliberal world order in East African newspapers. The Daily Nation of Kenya is the case study, and the epistemic genealogical worldview (highlighted in chapter three) is the guiding research orientation for this chapter. The core argument of this worldview, which draws from the global 
governmentality perspective, is that documents, whether in the form of policy, media reports or others, emerge from the problematization of particular aspects of social life. This chapter attempts to account for how the Daily Nation's problematization of ICT issues relates to the broader push for neoliberal world order. To determine whether the Daily Nation's coverage is implicated in this push, the chapter compares the Daily Nation's framing of ICT news in 2006 with the Kenyan government's framing of ICT issues. For this task I use critical frame analysis.

\section{Procedure for Data Collection}

The initial plan was to review two newspapers for each East African country, but I encountered two obstacles. The first was that the two widely-used search engines for newspapers, Lexis and Factiva, had inadequate coverage of East Africa as at January 31, 2007. Lexis has no newspapers at all in this region, and Factiva does not cover Tanzania and Uganda. The latter search engine has The Standard and the Kenya Times, but nothing on the leading newspaper in Kenya, the Daily Nation.

The second obstacle involved operational search engines. For example, The Standard (Kenya) and the Daily Monitor (Uganda) have search engines that do not work. Blackout was the other problem I experienced when gathering data from the The Guardian (Tanzania). I had access to data from January 1 to April 14, 2006, but nothing thereafter until November 30,2006 . As a result of these hindrances, I have analyzed the Daily Nation (Kenya) in depth and two others briefly-the Daily News (Tanzania) and The New Vision (Uganda). 
To gain access to as many articles as possible on information and communication technologies in the three newspapers, I used four levels of keywords. At the initial level, I typed "ICT/ICTs", and at the next level I used two keywords central to neoliberal global governance-liberalization and privatization. The third level involved seeking information on communication regulatory agencies for the countries under review. As noted in chapter two, the regulators are the Communication Commission of Kenya (CCK), the Tanzania Communication Regulatory Authority (TCRA), and the Uganda Communication Commission (UCC).

In the process of gathering data at the three levels, I noted that ICT enterprises were often featured in the news, and this led me to extend the search to another level by keying in the names of the leading ICT providers in East Africa, including the following partially privatized state telecommunication enterprises: Telkom Kenya (in the process of full privatization); Safaricom (Kenya); Tanzania Telecommunications Company Limited; Zanzibar Telecom Limited (Zantel); and Uganda Telecom Limited. I also entered the names of the following private enterprises: Celtel (Kenya, Tanzania, Uganda); Six Telecom (Tanzania); Vodacom (Tanzania); and Mobile Telephone Network (Uganda).

\section{Duration of the Study}

2006 was an eventful year-indeed, it can be regarded as the "ICT Year of East Africa." The year was packed with parliamentary bills and other ICT-related events in the East African countries under review, and indications were that it would be a year of public debate on ICT issues, including universal access. The expectation was that civil society organizations would seize the opportunity to campaign against neoliberal policies, and that newspapers would be busy publishing news of these happenings-which is the main 
reason why I chose January to December 2006 as the duration for this study. A list of parliamentary bills and events is provided hereafter.

In January 2006, Kenya released the official edition of its ICT policy (which had evolved from the $2004 \mathrm{draft}$ ). In the following month, the government published the Kenya Information Communications Bill 2006 and held the 2006 Kenya ICT Conference, during which it circulated the 2006 Kenya ICT Strategy. The Tanzanian government's Universal Communications Access Act, 2006 was made public in March of that year, and in June, the Ugandan government elevated the Department of Communications of the Ministry of Works, Transport and Communications to a full-fledged Ministry of Information and Communication Technology. Uganda's ICT Sessional Committee submitted the new ministry's budget to the parliament in August, and on August 31, the government held a seminar on the National ICT Master Plan, which was prepared by Mega-Tech Inc. (USA) and funded by the U.S. Trade and Development Agency.

\section{East African Newspapers and Neoliberal World Order}

I define neoliberal world order as that condition of human social, economic and cultural existence that is permeated by the phenomena of neoliberalization and neoliberal global governance as well as the rationality/ideology of global neoliberalism. This section seeks to determine whether East African newspapers are implicitly involved in promoting neoliberal world order, specifically in the communications sector. In my search for ICT related articles published between January 1 and December 31, 2006, I encountered only five on civil society organizations, in stark contrast to a total of 395 retrieved from the Daily Nation (Kenya), the Daily News (Tanzania), the Guardian (Tanzania), and The New Vision (Uganda). Table 5.1 (page 184) lists the number of articles on ICT issues per 
month for each newspaper. Below I summarize the contents of the five items on civil society organizations, the only representations of dissent in the push for neoliberal world order.

Daily Nation, January 28: A letter to the editor from a candidate for the secretarygeneral's position in the Communication Workers Union argues against the privatization of Telkom Kenya. The lone dissenter observes: "The parastatal must be sold to Kenyans and not to a strategic investor [transnational corporation] to enrich a few government fatcats with connections." The writer holds that a retrenchment programme (underway) should not focus on junior staff only but include senior and middle-level managers who earn huge salaries that constitute "half the company's recurrent annual budget."

Daily Nation, February 15: The newspaper reported that an umbrella civil society organization in Kenya, the Name and Shame Corruption Networks Campaign, ${ }^{33}$ had called for resignations over financial scandals involving the vice-president, four ministers, the attorney general, the head of the civil service, and the directors of the Kenya Anti-Corruption Commission and the Criminal Investigation Department. Seventy-five of the 220 members of parliament took this opportunity to voice their opposition to the privatization of state-owned enterprises, and threatened to join demonstrations organized by the Name and Shame Corruption Networks Campaign. The Daily Nation reported: "The MPs demanded the government stops the sale of Kenya

\footnotetext{
${ }^{33}$ Members of the Name and Shame Corruption Networks Campaign protest against government ministers and senior civil servants whenever they are implicated in grand corruption. This Kenyan network comprises over seventy civil society organizations.
} 
Power and Lighting Company, KenGen, East African Portland Cement, and Telkom [Kenya] expressing fears that privatization could be used to funnel out more taxpayers' funds." That was the first and last time in 2006 that the seventy-five legislators were reported to have spoken out openly to oppose privatization. Frame analysis of the Daily Nation (below) provided no evidence to suggest that those legislators had formed a united front against privatization.

Daily Nation, March 18: The secretary-general of the Communication Workers Union warned that the Union would seek legal remedy if Telkom Kenya proceeded with sending home its workers without an agreed severance pay package. The secretary-general registered his dismay at the management's action of retrenching workers while talks were still going on: "We are surprised that the management went ahead and effected their proposal even before our next meeting planned for March 29." It should be noted that the Union was not expressing opposition to privatization per se, but to the pay package of retrenched workers. This is an example of a labour movement narrowing its focus to issues pertaining to workers' conditions and benefits without giving much consideration to the broader issues affecting retained and retrenched workers. One of those broader issues is, of course, the privatization of Telkom Kenya and other state-owned enterprises.

The second half of this March 18 article reports that, during a meeting with the Women's Political Alliance of Kenya, an assistant minister in the Ministry of Planning and National Development commented that "an additional 200,000 jobs could be created after liberalization of telecommunications sector." The members of the Alliance were skeptical about the assistant minister's prediction. It could be argued that the assistant 


\begin{tabular}{|c|c|c|c|c|c|}
\hline$\stackrel{5}{\circ}$ & $\underset{\Xi}{\mathbb{G}}$ & $\widehat{\infty}$ & 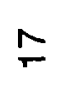 & $\stackrel{\widehat{N}}{\sim}$ & 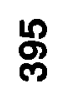 \\
\hline 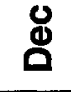 & $\stackrel{\infty}{\sigma}$ & $\omega$ & $\mathbf{i}$ & \pm & ఖ్ల \\
\hline zo & $\stackrel{L}{2}$ & $\forall$ & I & $\stackrel{1}{\Omega}$ & $m$ \\
\hline U & $\stackrel{ \pm}{ \pm}$ & $\sigma$ & I & $\mp$ & க \\
\hline 这 & $\stackrel{\infty}{-}$ & $r$ & 1 & 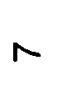 & ষ্ \\
\hline$\frac{\text { g }}{4}$ & $\stackrel{m}{2}$ & $F$ & i & $\stackrel{N}{\sim}$ & $\ddot{m}$ \\
\hline$\frac{2}{3}$ & \pm & 으 & i & $\tau$ & স \\
\hline$\stackrel{\text { g }}{5}$ & $\Lambda$ & $a$ & I & $m$ & S \\
\hline 离 & $\stackrel{20}{\sigma}$ & $\stackrel{\sigma}{\sigma}$ & i & 9 & $\mathcal{\gamma}$ \\
\hline 흔 & $\infty$ & 10 & i & ما & $\stackrel{\infty}{\leftarrow}$ \\
\hline $\begin{array}{l}\frac{5}{0} \\
\frac{\text { d }}{2} \\
\end{array}$ & 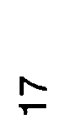 & $N$ & ما & $\omega$ & $\stackrel{\mu}{\mu}$ \\
\hline 这 & 으 & i & 10 & $\omega$ & $\bar{N}$ \\
\hline 䕍 & $\underline{\sigma}$ & i & $\lambda$ & $\forall$ & $\stackrel{\leftrightarrow}{\sim}$ \\
\hline 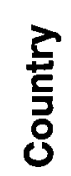 & $\begin{array}{l}\stackrel{\mathbb{N}}{\overparen{\mathbb{Q}}} \\
\stackrel{\mathbb{Q}}{\underline{y}}\end{array}$ & $\begin{array}{l}\stackrel{\mathbb{N}}{\mathbb{N}} \\
\stackrel{N}{\mathbb{N}} \\
\stackrel{\mathbb{N}}{V}\end{array}$ & 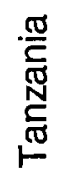 & 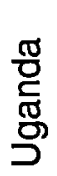 & \\
\hline 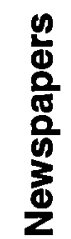 & 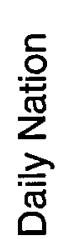 & 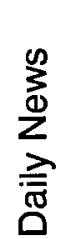 & $\begin{array}{l}\frac{5}{\frac{\pi}{7}} \\
\frac{0}{0} \\
\frac{\pi}{3} \\
0\end{array}$ & $\begin{array}{l}\frac{0}{0} \\
\frac{.0}{0} \\
\frac{3}{2}\end{array}$ & 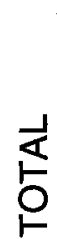 \\
\hline
\end{tabular}


minister was playing a political card in order to win support from the Alliance for the government's privatization programme.

Daily Nation, June 9: An opposition legislator was reported to have asked a question in parliament seeking a public statement on the various stages in the sale of Telkom Kenya. In the course of debate, a legislator within the ruling party "opposed the decision to sell Telkom, describing it as a strategic entity." As one would expect, the lone voice fell on deaf ears-privatization of Telkom Kenya is in progress, as noted later in this chapter.

Guardian, January 22: The Democratic Organization of Workers and African Trade Unions and the Confederation of Southern African Workers' Union, among other African labour movements, had met to discuss privatization under the auspices of the African Social Forum, a regional gathering of the World Social Forum. One participant admonished labour unions to fight for "nationalization of already privatised" state-owned corporations. The newspaper summarized the core argument articulated during that conference: "They [participants] said beneath the propaganda of efficiency through privatization is the reality of job losses and inaccessibility to essential social services like water, electricity, roads, transportation, education and health by the majority of African peoples."

One main observation suffices here: only five out of 395 articles in this survey report some element of resistance against neoliberal world order. This low number of articles indicates that East African newspapers eschewed reportage of the activities of civil society organizations. To ascertain this claim, I took the Daily Nation as a case 
study and sought to verify whether Kenya-based civil society organizations involved in ICT issues were featured in the newspaper during the selected time period. The following section provides the findings.

\section{Reporting Activities of ICT Civil Society Organizations}

In order to determine whether the Daily Nation covered or cited ICT civil society organizations, I had to access a list of these organizations. The website of the Association of Progressive Communications (in particular the section "Africa ICT Policy Monitor") was helpful in compiling such a list. On that website, I encountered two umbrella ICT civil society organizations: the Kenya WSIS [World Summit on the Information Society] Civil Society Caucus (KWSIS), and the Kenya ICT Action Network (KICTANet).

Civil society organizations in Kenya formed KWSIS in November 2002 after a workshop organized by the United Nations Economic Commission for Africa and the Association for Progressive Communications (Adam, 2006). KWSIS seeks to ensure that ICT policy provides for the poor, links ICTs to development and Kenya's competitiveness in the global market, and twins ICT civil society organizations with the private sector during the formulation and implementation of ICT policy (ibid.). In October 2004, KWSIS participated in consultations that brought about the formation of KICTANet. Other parties involved in KICTANet's launch were the Association for Progressive Communications, the Media Council of Kenya, and the Telecommunications Service Providers of Kenya (p. 7). KICTANet's mission is to perform the role of a catalyst for change in the ICT sector through two main strategies: sustaining a multi- 
stakeholder network on issues pertaining to ICT initiatives and policy; and establishing a meeting of minds among stakeholders in the ICT sector-government, firms, civil society organizations and the media (Kenya ICT Action Network, 2007).

From the membership of KWSIS and KICTANet, I compiled a list of ten ICT civil society organizations in Kenya, including the two networks and the following: the African Centre for Women, Information and Communications Technology; the African Network for Health Knowledge Management and Communication (AfriAfya); the African Women's Development and Information Network (FEMNET); the Arid Information Network-Eastern Africa; Collaboration on International ICT Policy for East and Southern Africa; the Kenya Community Media Network; the Kenya Information Society; and Slums Information Development and Resource Centers.

With the list of ICT civil society organizations in hand, I searched in the Daily Nation's 2006 archives for articles on each of them. The results: the newspaper had two articles on FEMNET but none on the other organizations. The FEMNET articles were published on February 23 ("NGOs Launch Campaign against Graft") and October 26 ("Clear Voices from the Last Forum"). The two articles are not about FEMNET - they just mention it. The February article includes FEMNET in a list of civil society organizations collaborating in the Name and Shame Corruption Networks Campaign. The October article reports anecdotal reflections of a FEMNET activist on the aftermath of the 1985 International Women's Conference held in Nairobi (Kenya).

The Daily Nation's dismal reportage of ICT civil society organizations motivated me to gather data on each organization's activities in 2006. The aim was to ascertain to what extent the organizations were active in the year under review. In general, I found 
that the ICT civil society organizations went about implementing their programmes, and I highlight two examples: the African Women's Development and Information Network (FEMNET), and the Arid Information Network-Eastern Africa (ALIN-EA).

FEMNET was established in 1988, and its objectives include the following: to empower African women to fight for gender equality in development initiatives (including public policy); to ensure networking on gender issues between the government and civil society organizations as well as development agencies; to advocate for a feminist perspective in development issues (such as the application of ICTs to urban and rural projects); to monitor implementation of the Dakar and Beijing declarations on women's rights; to lobby for inclusion of gender balance in policies emanating from the African Union and other bodies; and to encourage women to use ICTs when gathering, analyzing and disseminating information on gender issues (African Women's Development and Information Network, 2007). In 2006, FEMNET played a key role in organizing a consultative meeting of Eastern African media stakeholders under the theme "Strengthening Africa's Media" (Lukalo-Owino, Wambui \& Butenwa, 2006). The meeting was held on September 25 and 26, and the attending stakeholders included media owners, media practitioners, trainers of journalists, and professional organizations for journalists. Two public activities followed this workshop: a cartoon exhibition and competition on gender equality on October 27, and a prize-giving ceremony for the winners of the cartoon competition on November 7.

The Arid Land Information Network-Eastern Africa (ALIN-EA) is a network of more than 1,500 community development workers (CDWs) operating in arid areas of Eastern Africa (Arid Land Information Network-Eastern Africa, 2007). The Network 
started in 1987 but acquired its "Eastern Africa" designation in 1999 when it closed its Dakar (Senegal) offices and opened its headquarters in Nairobi (Kenya). This relocation also involved developing programmes for dry-land areas of Ethiopia, Kenya, Tanzania and Uganda (ibid.). ALIN-EA encourages CDWs to document their activities, experiences and aspirations in its Baobab Journal and lobbies for inclusion of issues affecting drylanders in policies geared towards creating a national and global information society. Three of its activities in 2006 stand out. In May, the organization participated in the "Stockholm Challenge" in Sweden, and because of its role in improving the quality of life in Eastern African dry lands, it became a finalist in the Environmental Category. The other activity occurred in August when ALIN-EA posted its Baobab Journal (Issue Number 47) on the Internet. Finally, it contributed towards fighting the AIDS stigma by launching a model HIV and AIDS Workplace Policy.

FEMNET and ALIN-EA were active in 2006 but their activities never saw the light of day in the Daily Nation. FEMNET's cartoon exhibition, competition and prizegiving ceremony were public events that would have attracted the newspaper's attention. Furthermore, FEMNET's media stakeholders' meeting related directly to media performance in Eastern Africa, and the expectation is that such a focus would have been a major concern of the Daily Nation. To top it all, FEMNET's events took place in the capital city of Nairobi where the newspaper has its head office, yet the Daily Nation never reported on any of these events. What can explain the newspaper's silence on ICT civil society organizations' activities in 2006? To answer this question I revisit the Daily Nation's framing of ICT issues in 2006. In order to set the context for this analysis, I first review the government's problematization of economic globalization within the issue- 
area of ICTs. The rest of the chapter presents an epistemic genealogical study that compares the framing of ICT issues by the Kenyan government to that of the Daily Nation. The chapter concludes with a commentary on the findings.

\section{The Problematization of Economic Globalization}

This section seeks to provide a general overview of the Kenyan government's framing of ICT issues within the problematic of economic globalization. Its entry-point is the 2006 Kenya ICT Strategy Conference (held on February 28), which was organized by the government in conjunction with the private sector and the World Bank. The President of Kenya was the guest of honour, and the minister for Information and Communications as well as a World Bank senior investment officer gave speeches during the conference. On this occasion, the government released a seventy-two page publication titled 2006 Kenya ICT Strategy: Collaboration \& Outsourcing for Economic Growth, which was divided into two documents: ICT Investment Guide, and ICT Strategy.

This study focuses on the strategy document. The government developed this document on the basis of the National ICT Policy document (2006a) and the economic solutions contained in its Poverty Reduction Strategy Paper (2001), The Economic Recovery Strategy for Wealth Creation and Employment, 2003-2007 (2003), and Development of Micro and Small Enterprises for Wealth and Employment Creation for Poverty Reduction (Sessional Paper No. 2, 2005) (Government of Kenya, 2006c, p. 45). Hereafter, I use critical frame analysis to extract the diagnostic, prognostic and motivational framing of the ICT strategy document in relation to the government's 
problematization of economic globalization. Figure 5.1 provides a snapshot of aspects of the discussion that follows by identifying the framing foci of the document.

\section{Diagnostic Framing}

In its diagnostic framing of the outsourcing issue, the government focuses on two settings: the world and the national context. Within the world context, the government holds that the digital divide is the main problem for developing countries, including Kenya. However, even though economic globalization can be blamed for the digital divide, it is a double-edged sword in the sense that it has the capacity to improve the human condition or worsen it if left unchecked.

The government argues: "These forces [of globalization and ICT] have the potential for bridging the gap between individuals and communities and isolating them at the same time; simultaneously creating clusters of information 'haves' and information 'have-nots'; and empowering people to contribute while at the same time restricting them to participate due to the digital divide" (2006c, p. 41). It is, therefore, up to governments to harness economic globalization and ICT in order to transform them into beneficial "forces" which can enhance living conditions in developing countries. The implication is that if economic globalization and ICT have created a "digital divide" across and within countries, governments are to blame because they have failed to tap the potential benefits of these "forces." This way of thinking encapsulated in the diagnostic framing of the ICT strategy document agrees with the broader framing of the ICT policies of the World Bank and East African governments (as shown in chapter four). The key point is that the problematization of economic globalization forms the basis of the Kenyan government's 


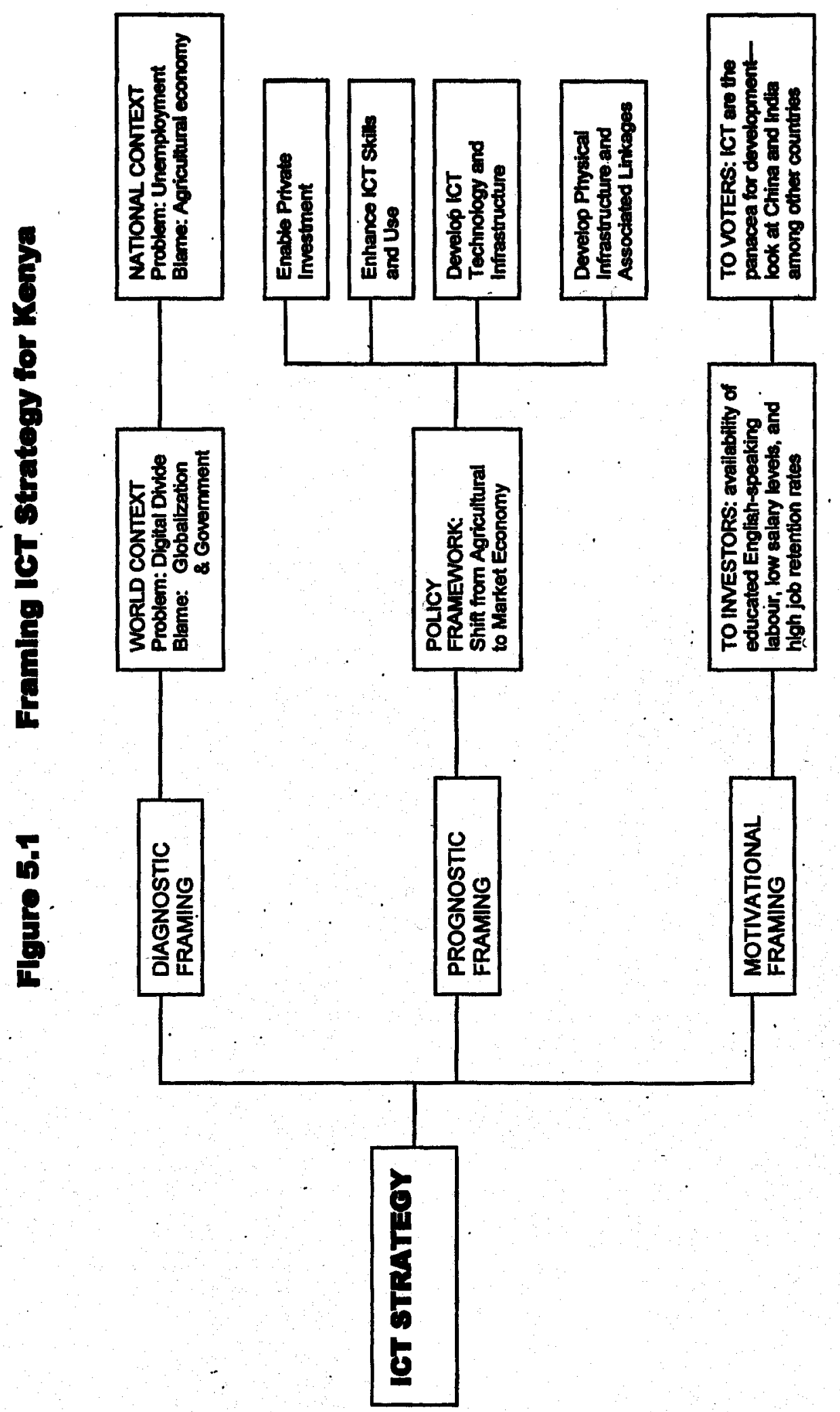


framing of ICT issues. It also influences the Daily Nation's framing of news reports (as demonstrated later).

Within the national context, the government's diagnostic framing of outsourcing singles out unemployment as the main social problem because it increases the prevalence of poverty and causes economic decline. The government declares: "The overriding goal of Kenya's ICT policy is to achieve progressive reduction in unemployment and poverty, the twin challenges that Kenya continues to face" (2006c, p. 44). It blames the high rates of unemployment on an agriculture-based economy, and seeks to "create a dynamic knowledge-based, technology-driven light modern industry sector which is export-led and globally competitive" (ibid.). In the envisioned knowledge-based economy, the private sector is the "key driver," and as such, the government is determined to "transform Kenya into an attractive destination for ICT-related Foreign Direct Investment (FDI) with the potential to become a competitive regional/international ICT and business hub" (ibid.).

The government holds that complementing an agricultural economy with a knowledge-based economic policy will turn around economic under-development, and expects that this shift will significantly improve Kenya's situation in the context of economic globalization and the national and international digital divide. One of the government's key strategies in transforming Kenya into a knowledge/information economy is to create a favourable business environment for Foreign Direct Investment in ICT-based services. This diagnostic framing spills over into the motivational and prognostic framing of the ICT Strategy document, as indicated in the following discussion. 


\section{Motivational Framing}

In its motivational framing of the ICT Strategy document, the government attempts to appeal to investors and the general public at the same time. To the people, the message is that ICT can transform Kenya in the same way the current communications technology revolution is turning around economic decline in other developing countries (Government of Kenya, 2006c, p. 41). The government asserts that "improvement in the provision of IT [Information Technology] has become a precondition for economic survival all over the world" (p. 45). To hammer home its point, the government notes that other countries—China, Costa Rica, Ghana, India, Mauritius, the Philippines, Poland, and South Africa—have improved their economies and generated jobs because they are using ICT (pp. 42, 55). The import of this motivational framing is that Kenya can gain from ICT as other countries have, and moreover, that its economic survival depends on utilization of ICT.

In addressing investors, the government observes that Kenya has experienced over forty years of political stability and has an ICT policy that is creating an enabling investment environment (pp. 45, 52). In addition, the government notes, investors located in Kenya's Export Processing Zone "enjoy a 10-year tax holiday followed by a $25 \%$ corporate tax rate for the following 10 years" (p. 52). Finally, Kenya is an attractive "outsourcing destination" because it has an educated English-speaking workforce, low labour costs, and potential for high job retention rates (given the current high rates of unemployment) (p. 59). Through this motivational framing of the ICT Strategy document, the government portrays Kenya as a low-cost business destination in which investors can maximize profits. The government is concerned about attracting Foreign 
Direct Investment, and consequently, within this focus, pays less attention to developing and encouraging local entrepreneurs in ICT-based services.

\section{Prognostic Framing}

The government adopts a four-pronged approach in its prognostic framing of the ICT Strategy document: enabling private investment, enhancing ICT skills and applications, developing ICT infrastructure, and building physical infrastructure and associated linkages.

Enabling Private Investment: In its ICT Policy (analyzed in chapter four), the government has declared its commitment to creating an enabling environment for private investment in the ICT sector (specifically through adherence to neoliberal policies of privatization and market and trade liberalization). To entrench further the private provision of ICT goods and services, the government in its ICT Strategy document promotes business incubation, brings in the idea of technology parks (TechnoParks), and encourages research in market intelligence. Business incubation is "the process aimed at encouraging entrepreneurs to start and grow businesses" (Government of Kenya, 2006c, p. 53). In support of business incubation, the government has promised to link potential entrepreneurs to "angel investors"-wealthy regional and transnational investors (p. 54). As for TechnoParks, they are geographical spaces reserved for small- and large-scale companies in ICT business (ibid.). In launching this concept, the government invites investors to establish businesses in designated high-tech locations. Finally, in its determination to enable private investment in ICT, the government offers to facilitate 
market intelligence. This practice involves gathering data on trends in the ICT sector in such areas as market share, customer spending, cost of products and services, emerging small and medium enterprises, and consumer profiles (p. 55). Marketing researchers collate and analyze data and produce documents for circulation to interested individuals and institutions.

Enhancing ICT Skills and Applications: In order to transform Kenya into a knowledgebased economy, the government seeks to encourage ICT use and integrate ICT education in curricula at all levels of education (2006c, pp. 44-51), and pledges to upgrade the education system in order to provide an ICT-oriented workforce. Moreover, the government intends to lead by example: "The implementation of e-government programmes would act as a catalyst for widespread ICT uptake by the business sector and the population at large" (p. 45). Finally, the government is looking for ways of reversing the "brain drain," especially in the ICT sector.

Developing ICT Technology and Infrastructure: The government encourages the private sector to invest in "manufacturing, assembly, repair and maintenance of computer and communication equipments and products" (2006c, p. 47). Another of its key concerns is the prevalence among ICT companies of the usage of outdated Very Small Aperture Technology (VSAT) (p. 61). The main problem with this satellite-based technology is the delayed response between users during international calls (ibid.). This is a major stumbling block for Kenya in its quest for market share in the global ICT outsourcing business because investors fear losing money through the inefficient VSAT system 
(ibid.). The government, therefore, appeals to the private sector to introduce technological innovations which can enhance ICT use in addition to bringing down operational costs (p. 55). It cites the case of Telkom Kenya, which has launched the ground-breaking Voice-over Internet Protocol (VoIP)—a technology that allows users to use the Internet for international calls (ibid.).

Finally, the government notes that "lack of a fiber-optic cable is a key impediment to the development of vibrant outsourcing industry in Kenya" (p. 61). To transcend this obstacle, it promises to provide national leadership in the construction of the Eastern Africa Submarine System (EASSy). The EASSy project, which includes the partner countries of Kenya, Madagascar, Tanzania, South Africa, and Uganda, was launched in 2003, but negotiations concerning issues of finance, implementation, and management are still going on. I revisit this project later when analyzing ICT news reports in the Daily Nation.

Developing Physical Infrastructure and Associated Linkages: The government considers ICT as part of the broader physical infrastructure sector, which includes electricity and water networks as well as railways and roads (2006c, pp. 41, 66). It also considers the development of ICT to be dependent on "soft" infrastructure-housing, transportation, security, and labour policies. Furthermore, the government seeks to make "institutional linkages"-that is, promote the centrality of ICT in the operations of local and central governments, and reach out to media and civil society organizations.

The foregoing epistemic genealogy of Kenya's ICT Strategy emerges from the problematization of the digital divide which, in turn, leads to a second 
problematization—-that of economic globalization. Thus, this ICT document, together with the Kenya's national ICT policy, share the World Bank's problematization of the digital divide as the entry-point to the framing of ICT issues. As shown in chapter four, the World Bank and East African governments adhere to the prognostic frame of private provision of ICT services as the best solution to the digital divide. Drawing from this broad prognostic frame, the Kenyan government commits itself, in its ICT Strategy document, to enabling private investment, enhancing ICT skills and use, developing ICT technology and infrastructure, and developing physical infrastructure and associated linkages. Underlying these policy strategies is the government's commitment to transforming Kenya into a knowledge-based economy. The envisioned social transformation is based on the adoption and diffusion of ICT, and is expected to integrate Kenya into the African and global information society. It is in this light, then, that I view the Kenyan government's framing of its ICT strategy document, as well as the following analysis of the president's articulation of ICT issues and the Daily Nation's reporting on ICT issues.

\section{The President's Framing of Kenya's ICT Strategy}

The preceding section has described the four-pronged prognostic framing of Kenya's ICT Strategy document: encouraging private investment, enhancing ICT skills and applications, developing ICT technology and infrastructure, and developing physical infrastructure and associated linkages. The government seeks to promote its prognostic framing of ICT issues through ten task groups: legal and regulatory, business development, marketing, finance, education and training, research and development, 
human resources, diaspora, technology, and associated infrastructure and linkages. Table 5.2 matches these prognostic framing foci with specific task groups and highlights the mandate of each task group. This analysis proves that the government is not only engaged in framing ICT issues in a particular way, but also that it is committed to promoting its mode of framing through the ICT task groups. This strategy further entrenches the government's mode of framing ICT issues among professionals participating in various task groups.

In the analysis that follows, I do a critical frame analysis of the president's speech during the 2006 Kenya ICT Conference (as printed in an abridged version in the Daily Nation of March 2, 2006). The main aim is to show that the president's speech emanates from the prognostic framing of the ICT Strategy document. This exercise lays the ground for my analysis of the Daily Nation's ICT reports. I have sidelined the framing strategy of the government's commitment to developing physical infrastructure and associated linkages because it is too broad; moreover, even though a task group has been mandated to implement it, the strategy itself is dealt with only briefly in the government's document. In order to narrow this study, I have focused on the other three framing strategies, which are directly linked to ICT. Figure 5.2 previews the president's speech from a framing perspective, and illustrates its various elements, which I expound on in this section and later on in this chapter.

\section{Enabling Private Investment}

ICT Policy: The president asserted that the ICT policy promotes market liberalization in ICT products and services. He observed that it is due to the opening of the Kenyan ICT market that the country had 5.5 million cellphone subscribers in 2006 as compared to 


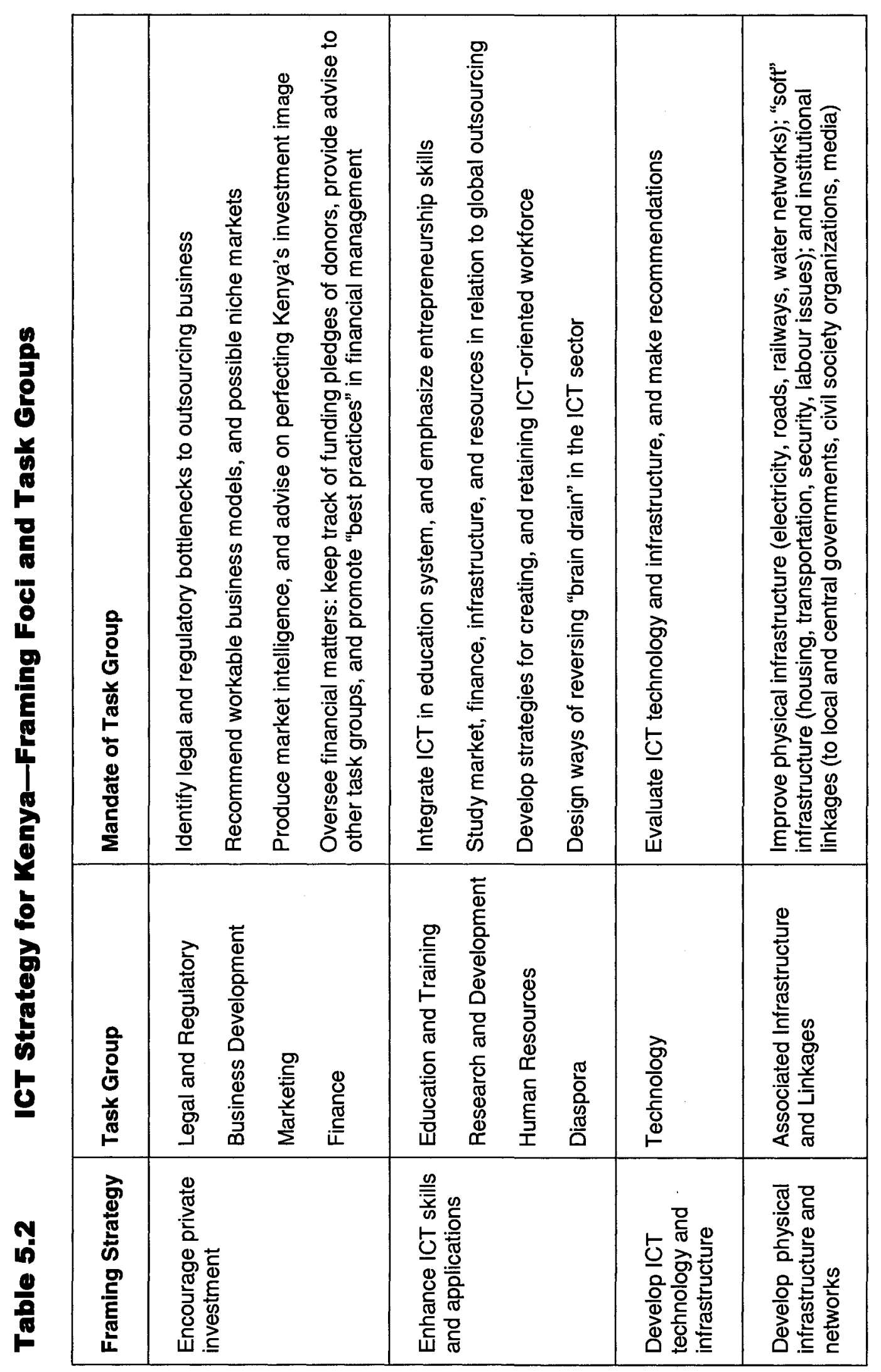




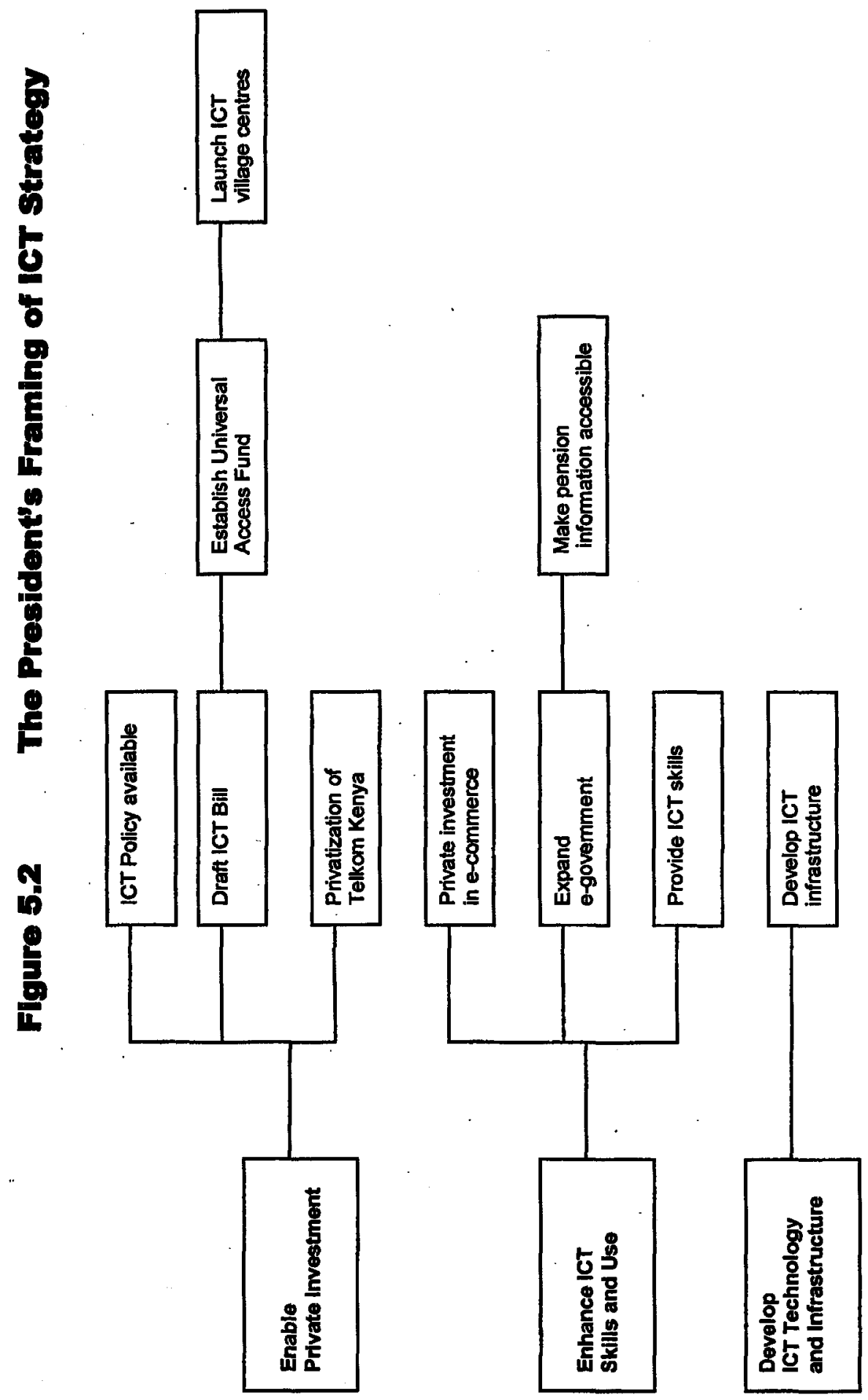


15,000 in 2000 . The president emphasized that "the government has fully liberalized the sector through opening up of the international gateways to other players and licensing of new operators to compete with Telkom Kenya" (March 2).

Draft ICT Bill: The President stated that the Bill would establish a Universal Access Fund which would pave the way for the creation of "ICT village centres." In launching these centres, the government wants "to ensure that wananchi ([the] public) in rural areas are able to access ICT free of charge" (March 2).

Announcement on Telkom Privatization: The president disclosed that the government had authorized the sale of its entire 60 percent share in Telkom ( 26 percent earmarked for purchase by a "strategic partner" and 34 percent open to the public). In addition, he announced, it would sell 9 percent of its shares in Safaricom, a mobile company, in order to fund "restructuring of Telkom Kenya." The president never mentioned that "restructuring" involved the retrenchment of about 12,000 of Telkom Kenya's workers. It was only through the analysis of the Daily Nation's news reports that "restructuring" emerged as a euphemism for cutting back workers.

\section{Enhance ICT Skills and Use}

Private Investment in e-commerce: The president invited the private sector to invest in ecommerce, and noted that when the draft ICT Bill is passed into law it will set the necessary legal framework for e-commerce. 
Expand e-government: The President highlighted that the government was expanding egovernment, and proposed that "the Pensions Department should work with the private sector to establish a call centre, [from] which pensioners can get information on their benefits" (March 2).

Provide ICT Skills: The president underscored the need to impart ICT skills to high school and university graduates to enhance their employability in the ICT age.

\section{Develop ICT Infrastructure}

The president observed that the government is committed to the development of an efficient ICT infrastructure, especially fibre-optic networks.

In his framing of ICT issues, the president derived the foci from the ICT Strategy document. Within the framing focus on private investment in the provision of ICT services, he revisited the national ICT policy and the draft ICT Bill. He also took the occasion of the conference to announce the privatization of Telkom Kenya. As for the framing focus on ICT skills and use, the president encouraged the private sector to engage in e-commerce. In addition, he declared that the government's cyberspace project was to diversify into customer service for pensioners, and that high school as well as university curricula were to incorporate the teaching of ICT skills and use. Finally, in the framing focus on ICT infrastructure, the president remarked that the government was exploring ways of developing ICT infrastructure. The next section takes the framing 
focus on private investment in the ICT sector and traces news extensions in the Daily Nation from January 1 to December 31, 2006.

\section{The Daily Nation's Framing of ICT Issues}

This section seeks to establish that the government's framing of its ICT strategy underpins the Daily Nation's news reports on ICT issues. To support this claim, I direct attention to the president's framing focus on private investment in the ICT sector, and do a critical frame analysis of the Daily Nation's reporting of ICT issues from that entrypoint. The president's framing of private investment separates into two strands, which in turn generate distinct news extensions in the Daily Nation. The strand on the ICT Bill extends into news reports on universal access, fees waivers for investors in rural areas, and debate on cross-media ownership. The other strand-market liberalization-evolves into news extensions on Nokia's entry into Kenya's market, the launching of a second call centre, the licensing of a second national telecommunications operator, and internetwork access costs for mobile phones. I elaborate on each of the two strands in the following sections.

\section{News Extensions from the Draft ICT Bill (see figure 5.3)}

On January 17 , the minister for information and communication announced that the cabinet had approved Kenya's ICT Policy, and that a draft ICT Bill was ready for tabling in parliament. The president re-stated this piece of information in his speech on February 28. Before this, however, on February 9, commentators Alex Gakuru and Grace Mutung'u had highlighted the main features of the ICT Bill: recognition of electronic transactions and documents as binding (in law) to the parties involved; posting of an 


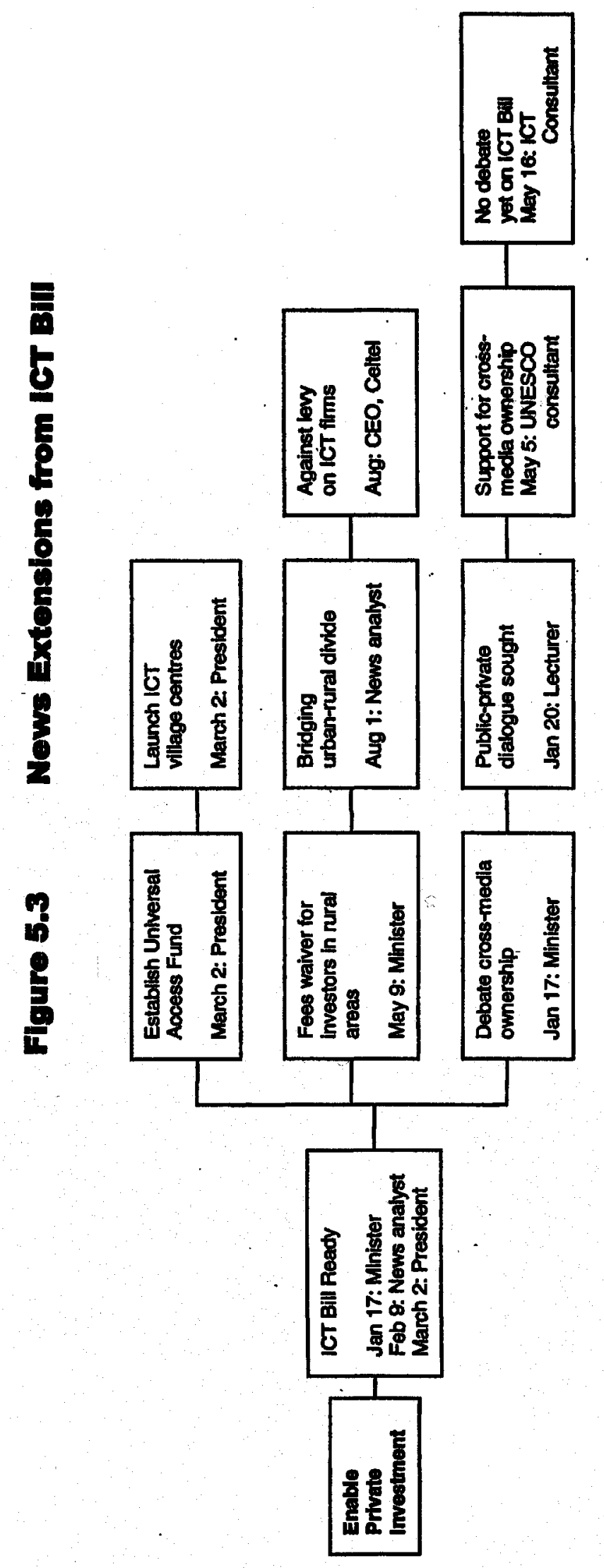


electronic copy of the Kenya Gazette (a publication that provides information on government policies, bills, and appointments to senior positions in the public service and state-owned enterprises among others); formation of a Universal Service Fund (to receive contributions from ICT operators, the national budget, the Communications Commission of Kenya, and other sources); transformation of the Communications Commission of Kenya into a "one-stop shop" for approving ICT business licences in addition to allocating radio spectrums; creation of three institutions - the Content Advisory Council, Universal Access Advisory Council, and Appeals Tribunal, to adjudicate on issues of fair competition, among others; and making it a criminal offence to engage in "reprogramming a stolen mobile phone, sending spam, tampering with electronic messages, such as emails and sms [short message service], misleading advertisements or hacking into computer systems."

Speaking on the draft ICT Bill, the minister appealed to parliamentarians to discuss it, and added a rider: "We want to get views on whether we should allow a single proprietor to own more than one radio station, newspaper and television station" (January 17). The Bill is silent on cross-media ownership but recognizes an emerging trend of technological convergence, which outdates the current regime of licensing entrepreneurs in computing, broadcasting, and telecommunications within different legal frameworks and at separate locations. The ministry's guide to the Bill notes that technological convergence has contributed to a situation whereby content providers are also becoming infrastructure service providers and vice versa (Government of Kenya, 2006d, p. 3). The Bill does not address this situation. It is, in fact, the ICT Policy that comments on crossmedia ownership: "In order to promote diversity of views and freedom of expression, 
concentration of print and electronic media in a few hands will be discouraged. Limits to cross-media ownership will be set through regulations to be issued from time to time and through competition laws" (Government of Kenya, 2006a, p. 22).

What is interesting is that the minister's comment on cross-media ownership caught the attention of Absalom Mutere of the School of Journalism, University of Nairobi, and George Okado, a UNESCO consultant and director of the Information Communication Technology Centre, Kenya. Mutere feared that the ICT Policy "will not be popular with individuals who own media outlets across the spectrum of channels" (January 20). Okado argued that cross-media ownership is a consequence of technological convergence, and comments: "It now makes a lot of sense for one company to run radio, television, newspaper and Internet publishing" (May 5). This focus on crossmedia ownership diverted attention from debate on the ICT Bill, and on May 16, an ICT consultant lamented that the general public had yet to enter this debate. I concur with this observation. In the course of reviewing the Daily Nation, I did not come across any substantive discussions of the ICT Bill.

I need to make two observations here concerning the ICT Bill. To a large extent, the government was seeking to enhance private investment in the ICT sector through the ICT Bill. For example, the Bill states that the Communications Commission of Kenya would become a "one-stop-shop" for licences pertaining to radio broadcasting and provision of Internet as well as mobile-phone services, among others. This mode of framing ICT services is similar to that of the World Bank's strategy for ICT development in developing countries, and to that which informs the Daily Nation's reporting of ICT issues. The other observation is that the Daily Nation adhered to official sources of news, 
and as a result, failed to correct the confusion created by the minister on the content of the ICT Bill. Checking the minister's comment against the ICT policy and Bill would have proved him wrong. That did not happen. What this indicates, then, is that the newspaper's management trusted official sources on the ICT Bill to the extent that they skipped the data verification stage in the editing process. This is a point I come back to when discussing findings.

\section{News Extensions on the Universal Access Fund (see figure 5.3)}

The minister for communication and information announced on May 9 that the government would waive licence fees for ICT entrepreneurs who invest in rural areas. He emphasized that, through this move and the proposed Universal Access Fund, the government was seeking "to ensure that every primary and secondary school has Internet access in the near future." To underscore the disparities in rural-urban distribution of ICT services, a news analyst on August 1 pointed out that the capital city of Nairobi alone takes up 56\% of the country's share of fixed telephone lines. The news analyst added that the current situation did not augur well for bridging the urban-rural divide in the ICT sector. To support that claim, the analyst cited a report by the Communications Commission of Kenya which asserted that "competition between operators, especially the mobile companies and Internet Service Providers, has tended, as expected, to marginalize the less lucrative rural areas" (quote in the Daily Nation, August 1, 2006). The commentator proceeded to report that the government expected the Communications Commission of Kenya to set aside initial money for the Universal Access Fund, and that ICT firms should contribute 1 percent of their gross annual income. In addition, the fund 
would benefit from a 20 percent share of the total annual fees paid by courier companies and the Postal Corporation of Kenya. The one-per-cent levy has not gone down well with the private sector-particularly Celtel Kenya, one of the key players in the Kenyan ICT sector. The company's chief executive argued that the levy should be scrubbed because it would bring about a price increase in ICT products and services (August 1).

The concept of a Universal Access Fund springs from the World Bank's prescription for "good policy practices" for ICT development in developing countries. The Bank (2002c) ties expansion of ICT services to a government's willingness to offer subsidies to potential investors in rural areas. The national ICT policy advances this view, as shown in chapter four. The licensing-fee waiver for rural-based ICT investors and the Universal Access Fund can be viewed as strategies for enhancing private investment in rural areas. Since ICT firms want to maximize profit, Celtel Kenya is opposed to the oneper-cent levy for ICT firms; however, the company is not against the Universal Access Fund in principle.

As for the Daily Nation, it does not provide background information on the implementation of the Universal Access Fund. Why not? The newspaper has relied on official sources in its reportage of this piece of news, and therefore it has followed the story line offered by the minister, and the government generally. It has avoided making the extra effort of analyzing the news in favour of reproducing the official framing of the Universal Access Fund. 
News Extensions on Market Liberalization (see figure 5.4)

The Daily Nation reported on March 21st that Nokia had entered the Kenyan ICT market. Another entrant was the Skyweb-Evans Company, which became the second call centre in Kenya after Kencall (October 3). However, the two news extensions that dominated the framing focus on market liberalization in 2006 concerned the second national telecommunications operator and the inter-network issue.

The Second National Telecommunications Operator: The government announced it was seeking a second national telecommunications operator to deliver fixed and mobile phone services (May 18). Answering a parliamentary question on July 6, the minister emphasized the government's resolve to open the ICT market and stated that Telkom Kenya's monopoly had already expired. On October 13, the director-general of the Communications Commission of Kenya said that the company that had won the tender for the second national operator would be known on October 27. On that day, the director-general broke the news that Vtel Consortium was to be the second national operator as of January 30, 2008 (October $28 \& 31$ ). The consortium had agreed to pay a licence fee of US\$169.7 million (the highest in the history of Kenya's ICT sector) by December 8. However, on December 24, it became public that Vtel had yet to pay its licence fee. The Daily Nation revealed that matters were so stormy within the consortium that Unitel Kenya's partnership had been cancelled. Vtel's chief executive officer said that the firm had failed to honour its share of the licence fee (December 24). The share holders in Vtel consortium at that time were: Vtel Holdings (Dubai, 60\%); Unitel Kenya (24\%, of which the Kenya Union of Savings and Credit Cooperative owns 5\%); 


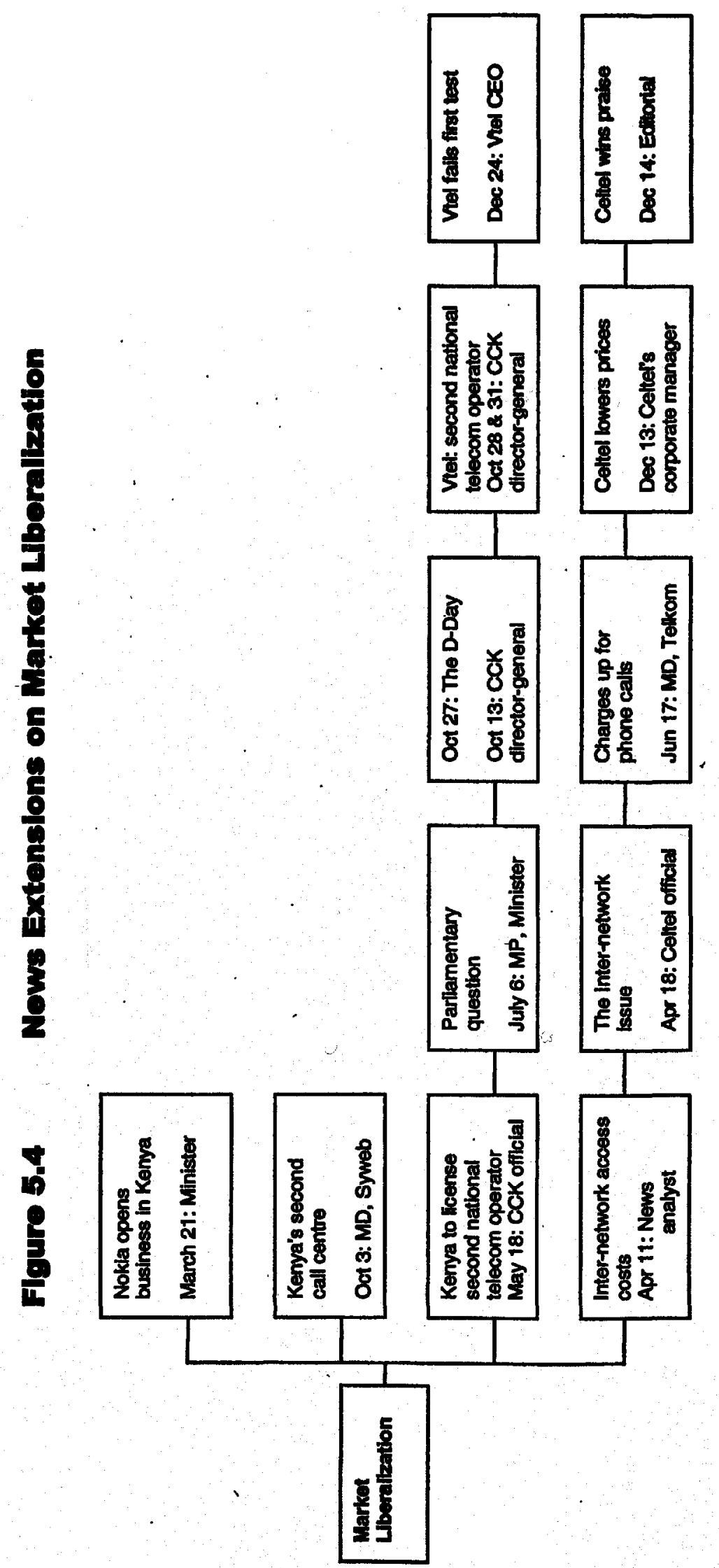


Palestinian Telecommunications Company (Paltel) (10\%); and Kirinyaga Construction Company (Kenya, 6\%).

Inter-Network Charges: On April 11, a news analyst raised concern about inter-network costs that restrict cell phone subscribers to calling and receiving calls only within their network. The analyst interviewed the chief executive of Celtel Kenya, a sales executive of Safaricom, and a businessman (a Celtel Kenya subscriber), and came to the conclusion that Kenyans were stuck within their networks to avoid more charges. Celtel, Safaricom, and Telkom were the only mobile telephone companies in Kenya as of December 31, 2006. Telkom focused on lowering calling costs from landline to mobile telephony but increased charges within its network (July 17). To tackle the inter-network issue, Celtel Kenya lowered charges for calls made outside its network (as reported on April 18). It also created "one network" within East Africa in that Celtel subscribers in Kenya, Tanzania and Uganda could call from one country to the other at local rates (September 28). Finally, the company lowered charges to its subscribers who call recipients in Safaricom and Telkom networks. This move won praise from the Daily Nation (December 14).

This critical frame analysis of news extensions on market liberalization indicates that the Daily Nation depended on official sources in 2006. In its reportage of the second national telecommunication operator, sources of information included the minister for communication and information, the director-general of the Communications Commission of Kenya, and Vtel management. Moreover, the April 11 edition of the newspaper reported that a news analyst had conducted a survey on inter-network charges, 
which included only official sources in the sample. I have highlighted this tendency of the Daily Nation's over-reliance on official sources when commenting on news extensions from the ICT Bill and the Universal Access Fund. This section, therefore, has found that Daily Nation's reportage of ICT issues has, mainly, followed the framing set by government representatives. This is an issue that needs explaining, and the next section seeks to do that.

\section{Discussion of Findings}

\section{Lack of Prominence of ICT Civil Society Organizations}

Why is prominence of ICT civil society organizations lacking in the Daily Nation's coverage of ICT issues? I propose that the reason is that this newspaper has used what I refer to as "generative reporting" in this particular domain of news. I derive the concept of "generative reporting" from Lindsay Prior's conception of a generative document as "a document that lays down rules as to how other documents should be constructed" (2003, p. 34). When looked at through the lens of an epistemic genealogical perspective, a generative document can be defined as a text that identifies, analyzes and presents an issue as a social problem that can be solved in a certain way. In this sense, the World Bank publications analyzed in chapter four are the generative documents underpinning Kenya's ICT policy document as well as its 2006 Kenya ICT Strategy.

By virtue of adhering to the government's framing of the Kenya ICT Strategy-a generative document-the Daily Nation has engaged in generative reporting. I propose two characteristics of generative reporting that I derive from the findings of the epistemic genealogical study of this newspaper's ICT news. First, the newspaper framed (and reframed) ICT news in 2006 in line with the problematization of ICT issues set out by the 
Kenya ICT Strategy. I have illustrated in figures 5.1 to 5.8 how the Daily Nation's ICT reports can be traced to this particular generative document. Furthermore, the preceding sections have attempted to show that the president elaborated on the Kenya ICT Strategy's framing focus on private investment. In his exposition of this document, he announced that the government intended to privatize Telkom Kenya (figure 5.2). This news report evolved into numerous articles published in the Daily Nation in 2006. For example, the news extensions on the sale of Telkom Kenya's nine-percent share in Safaricom ushered in talks between the government and the other principal shareholder of Safaricom, Vodafone of Great Britain. The talks began in London on September 19, and by November 1, no deal had been reached. The principal shareholders resumed talks in Nairobi (Kenya) as reported on November 15, but again failed to reach an agreement, according to Kenya's permanent secretary for the Ministry of Information and Communication (December 14).

By engaging in generative reporting, the Daily Nation defined the ICT situation in Kenya (in 2006) from the perspective of official sources, both public and private. This is the second characteristic of this newspaper's generative reporting of ICT news. The newspaper gives primacy to official sources thereby sidelining ICT civil society organizations and other alternative sources of news (see figures 5.1 to 5.8). To support this point, I refer the reader to figure 5.5, which illustrates the framing focus for "enhance ICT skills and use." The sources of information for its six strands are as follows: ecommerce (investors, minister); e-workplace (veteran journalist, director of Kenya AntiCorruption Agency, judiciary spokesperson); e-cooperative (cooperative minister, senior 


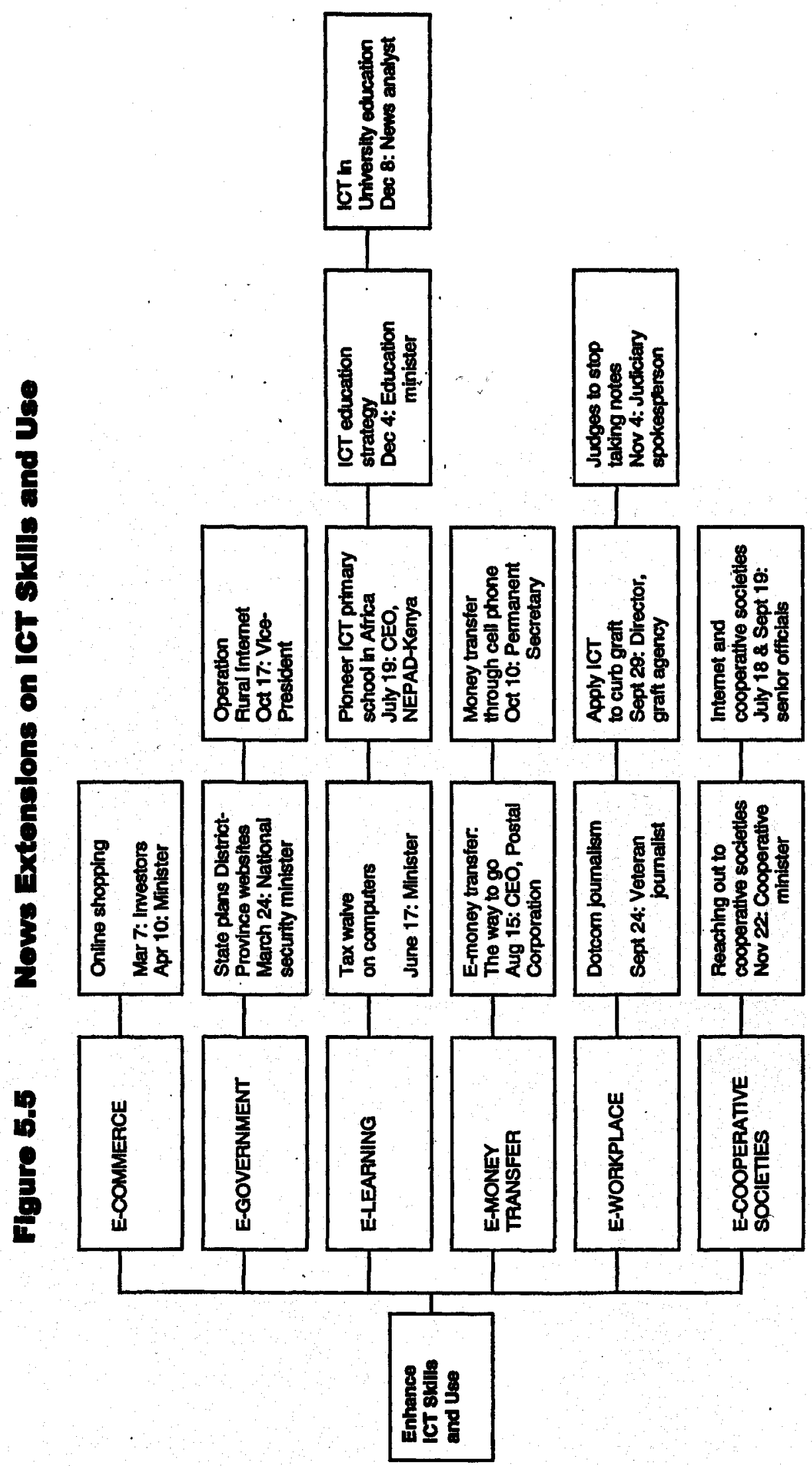


officials of cooperative societies); e-money transfer (chief executive officer of the Postal Corporation of Kenya, communication permanent secretary); e-government (national security minister, vice-president); and e-learning (communication minister, chief executive officer - New Partnership for Africa's Development, education minister, news analyst).

\section{Doing Ideological Work}

To what extent has the Daily Nation contributed to the transformation of global neoliberalism from a "global-popular" to a "national-popular" ideology? From a Gramscian epistemology, based on the concept of "national-popular," the World Bank's primary aim in its annual reports and other media-related strategies is to promote global neoliberalism as a "global-popular" rationality/ideology. What the Bank is seeking to do is to (re)produce a worldview that social elites of developing countries are expected to draw from when proposing, debating and formulating national policies on the economy and communications, among other issues. Chapter four has shown that East African governments have transformed global neoliberalism from a "global-popular" to a "national-popular" ideology by formulating communications policies in line with key tenets of the World Bank's version of global neoliberalism (specifically as it relates to the communications sector). This critical frame analysis of the Daily Nation indicates that this newspaper is also engaging in the ideological work of transforming global neoliberalism from a global- to a national-popular rationality/ideology. To support this claim, I call attention to figure 5.6 - news extensions on the privatization of Telkom Kenya (with special reference to editorials and commentaries). 


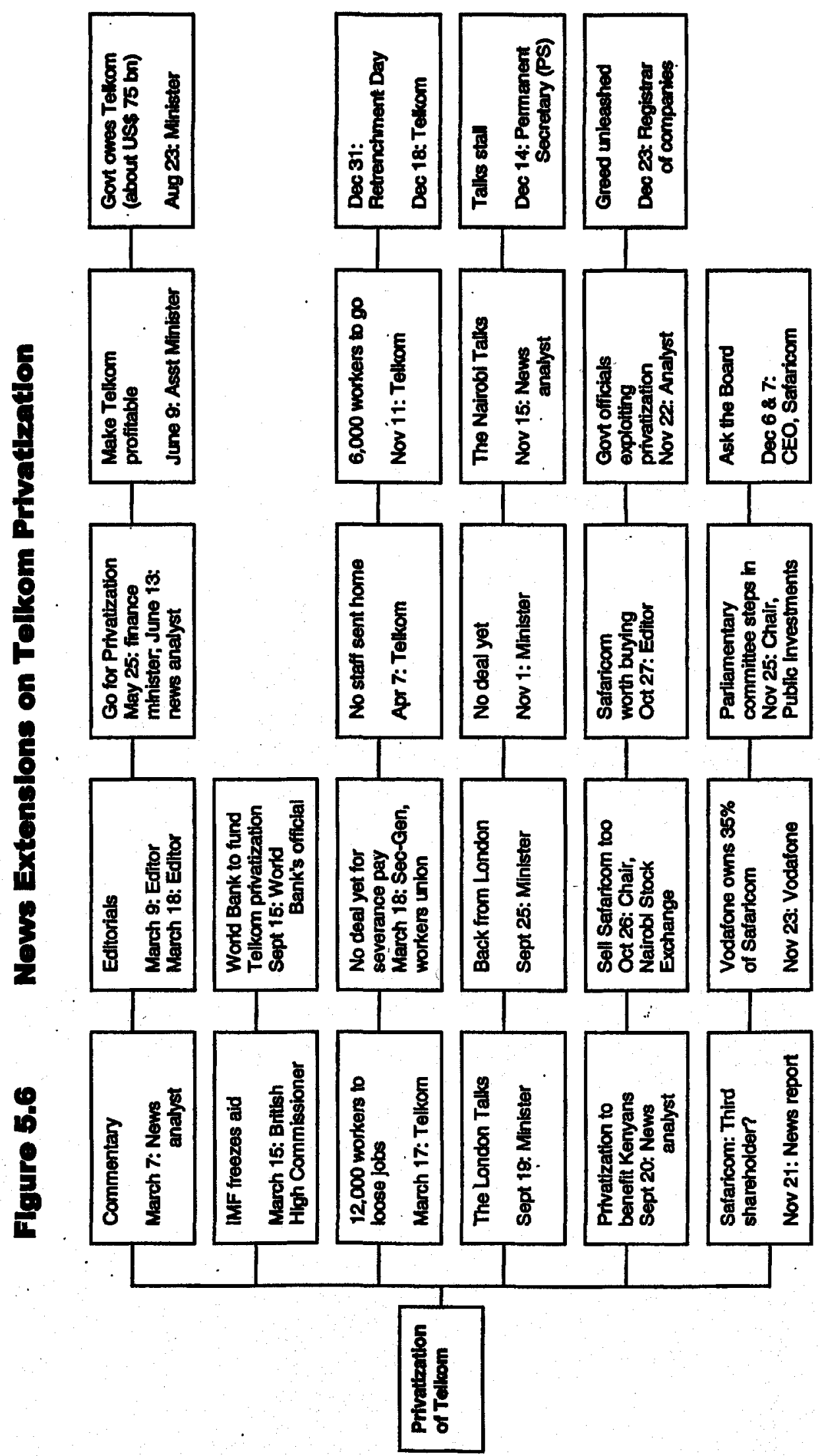


In its editorial on March 9, the newspaper praised the president's announcement on the privatization of Telkom Kenya: "The most significant business news of the past week was undoubtedly the intended sale of 60 percent of stake in Telkom." The editorial proceeded to support privatization in all sectors of the Kenyan economy by arguing that only through implementation of privatization can there be "economic efficiency." Indeed, the editorial of March 18 maintained, "Privatization is the way out" for Kenya. However, to fund retrenchment of workers and restructuring of Telkom Kenya, the government sought to sell nine percent of its 60 percent share in Safaricom. The company reported a pre-tax profit of about US\$174.1 million for the 2005 financial year-making it the most profitable mobile phone company in Kenya (October 26). Yet on October 26, the newspaper reported that the chairman of the Nairobi Stock Exchange said to the president, "If you are considering a Christmas or a new year gift for Kenyans, I strongly suggest that your government agrees to shed at least 20 percent of its shareholding in Safaricom through NSE [Nairobi Stock Exchange] early next year." The following day, the newspaper released an editorial reiterating its support for privatization: "The newly released figures [of pre-tax profit in Safaricom] should set the government rethinking its ownership of public enterprises." It calls upon the government to sell shares to "ordinary Kenyans" as "investor of first resort." ${ }^{34}$ Unfortunately, ordinary Kenyans are not benefiting from the privatization of state-owned enterprises. Two strands of news extensions—secret shareholders and greed unleashed—on "Telkom privatization" prove this point.

${ }^{34}$ The Daily Nation's editorial of March 18 argued: "Privatization also has the advantage of giving the public a share in owning institutions that were originally set up with their money" (emphasis added). 
Secret Shareholder: On November 21, it became public that the owners of Safaricom numbered three and not two as previously believed—the government through Telkom Kenya (sixty percent), and Vodafone (forty percent). The third shareholder-Mobiltelea Ventures—had secretly acquired a five percent share from Vodafone, reducing Vodafone's share to thirty-five percent. Vodafone Group (United Kingdom)—-the parent company of Vodafone (Kenya) - confirmed that it owned a thirty-five percent share in Safaricom (November 23). The head of the investments department in the Ministry of Finance remarked: "I am in the dark like any person in the streets; I have always thought it's 60 percent for Telkom and Vodafone, 40 percent" (November 21). The managing editor of The East African ${ }^{35}$ authored a commentary in the Daily Nation emphasizing that the Mobiltelea story "is an exposé that gives the public a rare glimpse of how privatization can be exploited by people in power to transfer public assets to themselves" (November 22). The editor blamed the law for this occurrence: "The saga also raises an important policy question: is it not time we rethought the rule stipulating that a company being privatized must sell 30 percent of its shares to local investors? All that this rule does is to make it possible for political elite to arm-twist foreign investors to give them shares free of charge." The Daily Nation framed articles on secret stakeholder articles as investigative pieces on grand corruption.

The question remained: Who owns Mobiltelea Ventures? The newspaper proclaimed in its editorial, "Kenyans Deserve to Know" (November 22). And for its part, Parliament's Investment Committee demanded an answer from the chief executive officer of Safaricom (November 25). The company head did appear before the Committee but he was tight-lipped on Mobiltelea ownership. Instead, he told the Committee that the

${ }^{35}$ The Nation Media Group owns both the Daily Nation and The East African. 
ownership question was outside his jurisdiction and could only be answered by Safaricom's board of directors (December 6 and 7). On December 31, when this study ended, the issue of Mobiltelea's ownership remained unresolved.

Greed Unleashed: In a December 23 article titled "How the Wealthy Plot to Own Public Firms," the Daily Nation disclosed: "Rich Kenyans are registering multiple companies which they are using to accumulate shares in public firms being offered for sale." The newspaper observed that the Registrar of Companies would normally process seven hundred applications per month, but with news of the upcoming sale of Telkom Kenya and other state-owned enterprises, the number rose in November 2006 to thirty-five hundred applications. This was a record high in the history of that department. By holding shares in many companies, a rich individual can get around the legal limit on the number of companies that an individual can own. In Kenyan law, companies trade as independent entities regardless of who owns them. What are the implications of this phenomenal rise in the registration of companies? The article responds: "The move could lead to only a few rich individuals owning the companies which are being offered to the public unless law is enacted to check the practice."

Two main observations suffice as regards determining whether the Daily Nation has participated in the ideological work of transforming global neoliberalism from a global- to a national-popular rationality/ideology. First, critical frame analysis of the Daily Nation's news reports on ICT issues leads to the conclusion that it is implicated in the promotion of global neoliberalism. This study has found that the newspaper supported market/trade liberalization and privatization - the pillars of global neoliberalism- 
through editorials on March 9, March 18 and October 27; and commentaries on March 7, June 13, and September 20. The newspaper's silence on the plight of Telkom workers targeted for retrenchment is another indicator of its implicit support for global neoliberalism.

Although the Daily Nation does neoliberal ideological work, it also takes its watchdog role seriously. This is the second observation. The news extensions on secret shareholders and greed unleashed testify to this position. The newspaper is against grand corruption in terms of closed-door deals on the sale of shares in firms that are partially owned by the state. The newspaper's argument is that those in government can collude with private firms to acquire shares in state-linked firms, as feared in the cited case of Safaricom ownership. In addition, the Daily Nation has exposed schemes of the rich in which they seek to own as many shares as possible in state-owned enterprises undergoing privatization. The upshot of this piece of information is that the rich are blocking "ordinary Kenyans" from sharing in the ownership of privatized state-owned enterprises. One important factor that the newspaper fails to consider is to define ordinary Kenyans in terms of the economic parameters of inclusion in this category. The key point, though, is that in its watchdog role, the Daily Nation does not question global neoliberalism - the rationality/ideology that has created the opportunity for secret ownership of a state-linked ICT firm and brought on the increased registration of private firms in readiness for buying privatized state-owned enterprises. In essence, then, the newspaper is one of the main participants in the ideological work of entrenching global neoliberalism in Kenya. The above cited observations underscore the basic premise of this critical frame analysis: news production is not an objective process, because it is permeated by the 
journalistic rationality of professionalism, and above all, by prevalent socio-political rationalities such as that of global neoliberalism. This section concludes that the Daily Nation in its reportage of ICT issues in 2006 operated within the neoliberal worldview.

\section{Hegemonic Media Frames}

To what extent have the government and the Daily Nation succeeded in creating neoliberal hegemonic frames? I have noted in chapter three that critical frame analysts follow Stuart Hall in his application of the Gramscian epistemology to mass communication studies. Critical frame analysts insist that there exist "hegemonic media frames" in two overlapping senses: these frames are produced by "hegemonic institutions," which include states and media, among others; and that they seek to build consensus among various social groups. I address these twin characteristics in relation to the hegemonic institutions of the Kenyan government and the Daily Nation.

Hegemonic Institutions: Figure 5.1 outlines the four branches of the government's prognostic framing of its ICT strategy: enabling private investment, enhancing ICT skills and use, developing ICT technology and infrastructure, and developing physical infrastructure and associated linkages. I have shown that the president's speech developed into three framing foci that extended into seven news items as indicated in figure 5.2: enabling private investment (ICT policy, draft ICT Bill, Telkom privatization); enabling ICT skills and use (private investments in e-commerce, expand e-government, provide ICT skills); and developing ICT technology and infrastructure (develop ICT infrastructure). Figures 5.3, 5.4 and 5.6 illustrate news extensions of the framing foci of 
enabling private investment; figure 5.5 maps out news extensions on ICT skills and use; while the extensions referring to the development of ICT infrastructure and adoption of ICT technology are outlined in figures 5.7 and 5.8, respectively. See figures 5.7 and 5.8 overleaf.

What the eight illustrations show is that the hegemonic institution of the Daily Nation is reinforcing policy aspects of the other hegemonic institution-the Kenyan government. Hence, both institutions participate in creating and maintaining a "hegemonic media frame"- that is, a specific way of defining ICT issues and solutions that feeds into a commonsense mode of thinking about the phenomenon of ICT among the general public. The frame emphasizes privatization and liberalization of markets and trade, and this agrees with the World Bank's neoliberal project as discussed in chapter four. In presenting articles within this hegemonic frame, the Daily Nation is participating in the Kenyan government's ideological work, which conforms to the World Bank's version of neoliberal globalism.

Building Consensus: In its motivational framing of ICT, the government seeks to appeal to investors and voters (figure 5.1) and to win them over to its ICT plan. I discuss voter appeal first, and then investor appeal. The government attempts to attract voter attention in its prognostic framing of the enhancement of ICT skills and use-especially in the areas of e-government, e-learning, and e-cooperative societies (figure 5.6). For example, according to a Daily Nation report, the national security minister said that an egovernment project was in the pipeline, and that on completion, it would provide Internet links between district and provincial offices as well headquarters of ministries (March 


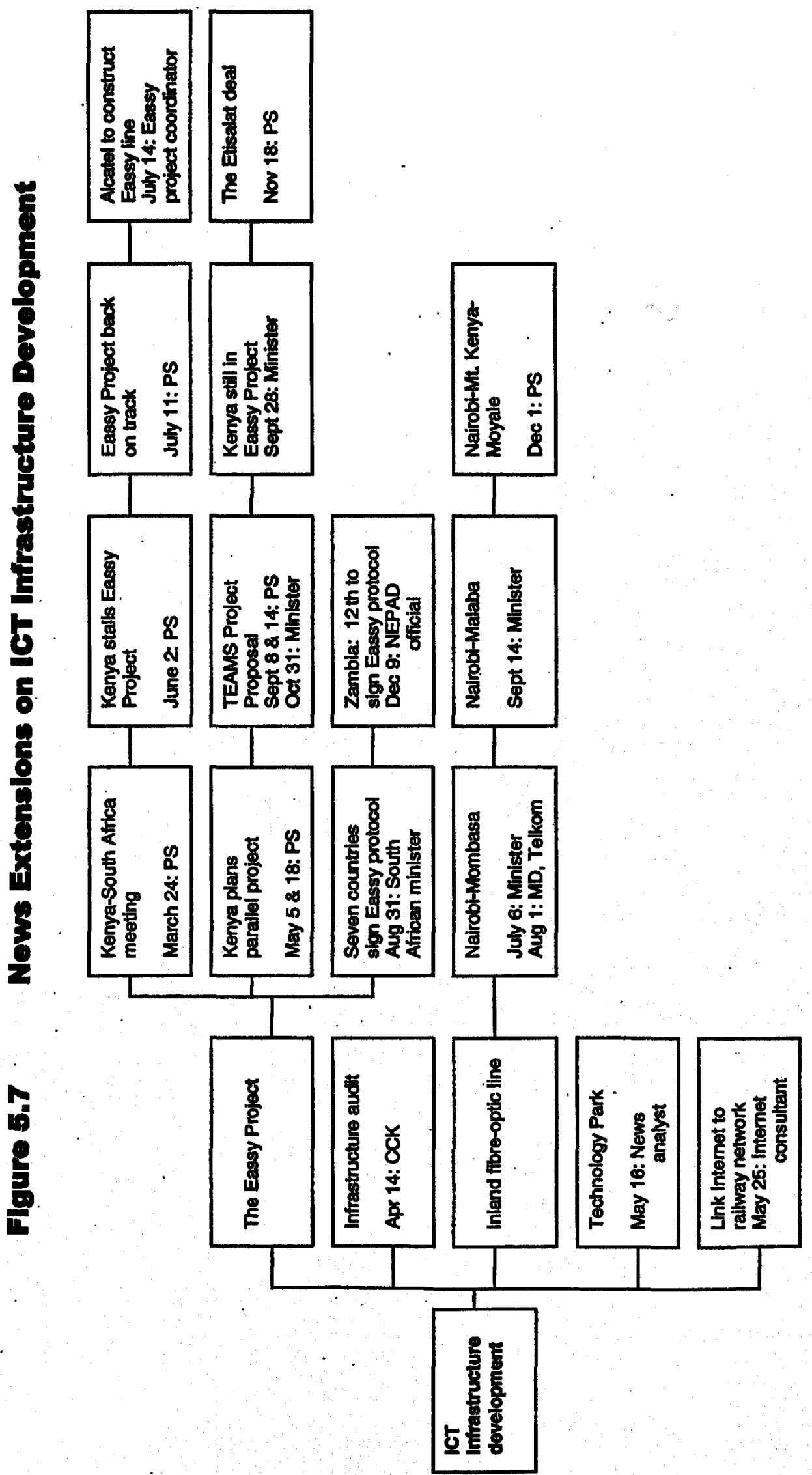




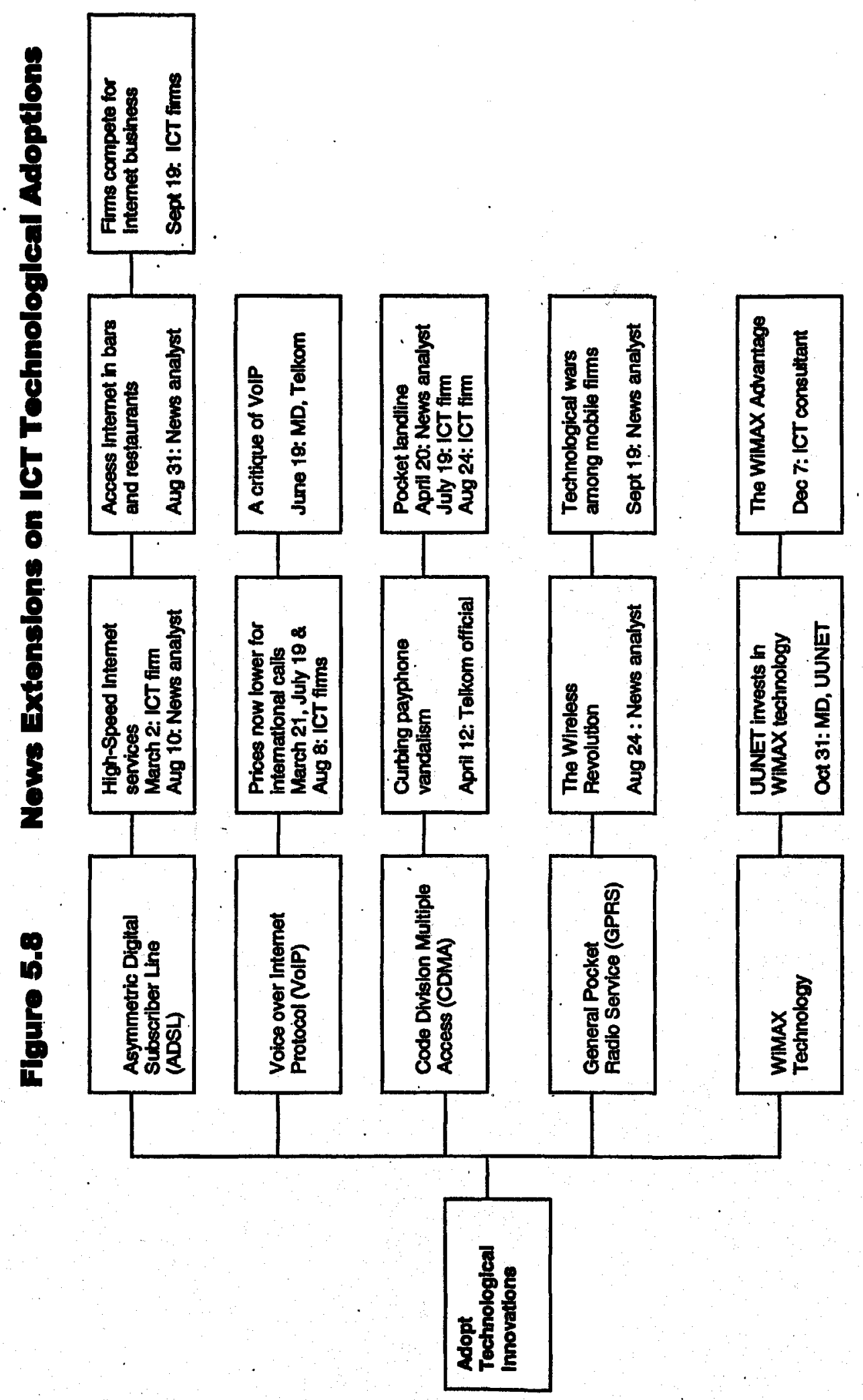


24). The minister asserted, "It [e-government] will facilitate better and efficient delivery of information and services to the citizens and promote efficiency, effectiveness, transparency and accountability of exchanges within government, between the government and the citizens and between government and business, locally and abroad."

As regards investor appeal, the government engages in ICT infrastructure development and encourages companies to adopt ICT innovations. Figure 5.7 shows news extensions on ICT infrastructure development: the regional project-the Eastern Africa Submarine System (EASSy); Kenya's parallel project-The East African Marine System (TEAMS); the construction of an inland fiber-optic network; the launching of a "pocket landline"; efforts to link the Internet to the railway network; plans to build technology parks; and a proposal for an annual or periodic audit of ICT infrastructure. Figure 5.8 shows that the framing focus of technological adoption evolved into articles on companies' adoption of the ICT technologies of Asymmetric Digital Subscriber Line (ADSL), Voice over Internet Protocol (VoIP), Code Division Multiple Access (CDMA), and WiMAX technology. The key point I draw from figures 5.7 and 5.8 is that the government and the Daily Nation, in their role as hegemonic institutions, seek to attract investor confidence by projecting an image of Kenya as a country that is entering an era of technological development.

\section{No Immanent Critique}

The Frankfurt school of critical social philosophy bequeathed to critical communication studies the research focus of "immanent critique" (Held, 1980, pp. 183-187). Simply put, immanent critique seeks to determine "the breach between ideas and reality" (Max 
Horkheimer as cited in Held, 1980, p. 183). In this research orientation, social institutions are evaluated by contrasting stated goals with their implementation. The Kenyan government disclosed its policy position on ICT in the 2006 ICT Strategy Paper, but I have not found a single article in the Daily Nation that assesses the implementation process of that document. I was expecting, too, that the paper would appraise the document with the aim of creating more public awareness of ICT issues.

\section{Unexpected Support}

This chapter has found that the Daily Nation fails to include or engage in substantive discussion of ICT policies and related issues. This finding is supported by a research project—Highway Africa—of the Department of Journalism and Media Studies at Rhodes University (South Africa). In 2004, Highway Africa researchers surveyed six sub-Saharan African countries-Kenya, the Democratic Republic of Congo, Ethiopia, Mozambique, Nigeria, and Senegal. Their report, Absent Voices, Missed Opportunities (2005), concludes: "The media is silent in terms of relevant ICT-related policy agendasetting or debate, and policy formulation, implementation, monitoring and review" (p. 3).

This chapter has gone further than the Highway Project, and has asked why East African newspapers are silent on the influence of the neoliberal worldview on communication policies. It has linked the Daily Nation's ICT coverage in 2006 to the framing foci of the Kenyan government's ICT Strategy Paper and the President's prognostic framing of ICT issues. This finding leads to this observation: the Daily Nation is doing ideological work for the government (and the World Bank, among other international development organizations). Thus, the diffusion of global neoliberalism is 
enhanced not only by East African governments but also by the largest newspaper in the region-the Daily Nation.

\section{The Permeation of Global Neoliberalism}

This chapter has taken the oppositional framing of cultural sovereignty (derived from East African ICT policies) as the entry-point to discussing interactions between East African newspapers and global neoliberalism. Most significantly, this approach has offered an opening for evaluating the permeation of global neoliberalism beyond national ICT policies to the leading newspaper in East Africa-the Daily Nation. The conversion of global neoliberalism from a global- to a national-popular rationality/ideology by the Kenyan government and the Daily Nation, among others, contributed in 2006 to the pervasiveness of global neoliberalism within the communications sector. The consequence is that this trend has left little room for challenging the epistemic foundations of East African communications transformations through the oppositional framing of ICT issues.

Based on three basic findings, this epistemic genealogical study has found global neoliberalism to be a pervasive rationality/ideology that underpins reportage of East African communications transformations, specifically in Kenya. First, in its framing of ICT issues, the government aims to transform Kenya into a knowledge/information economy. This framing thrust is related to the international development organizations' project of building an African information society within the broader global information society (as discussed in chapter two). Moreover, the government draws its framing thrust for the knowledge/information economy from the problematizations of economic 
globalization and the digital divide as presented in the 2006 Kenya ICT Strategy. The two problematizations stem from the World Bank's framing of ICT issues, as shown in chapter four.

The other finding is that the Daily Nation in 2006 derived its framing of ICT issues from the government's framing of the Kenya ICT Strategy. Through critical frame analysis, this epistemic genealogical study has attempted to trace the framing focus on private investment from the Kenya ICT Strategy to the president's speech and the Daily Nation. It has found that the president's framing of the Kenya ICT Strategy formed the template on which the Daily Nation reported ICT news in 2006.

Emerging from the preceding finding is the concern about this newspaper's adherence to the government's framing of ICT issues. This leads to the third finding: the Daily Nation relied primarily on official sources in its reportage of ICT issues in 2006. From an epistemic genealogical perspective, this chapter has argued that the newspaper's practice of generative reporting contributed in 2006 to its dependency on official sources. Furthermore, from a Gramscian perspective, the newspaper's generative reporting can be viewed as promoting the transformation of global neoliberalism from a global- to a national-popular rationality/ideology. It follows, then, that the Daily Nation is involved in the ideological work of entrenching global neoliberalism as a prevalent economic perspective.

Informed by an epistemic genealogical perspective, this chapter has tried to show that global neoliberalism is pervasive in that it is not only promoted by East African governments but also by the principal mainstream newspaper in that region-the Daily Nation. This pervasiveness of global neoliberalism and lack of major resistance shield the 
epistemic foundations of East African communications transformations from public and academic scrutiny. Hence, global neoliberalism continues to be the underlying rationality/ideology of changes in East African mediascapes.

The global governmentality worldview adopted in this dissertation, and its derivative epistemic genealogical perspective, open the epistemic dimension of East African communications transformations for investigation. This theoretical framework has facilitated inquiry into the epistemic domain that the liberal theory of communications transformations obscures (as noted in the introductory chapter). The next chapter provides an in-depth analysis of the implications and contributions of a global governmentality approach to the study of East African communications transformations. 


\section{CONCLUSION}

\section{BRINGING IT ALL BACK HOME ${ }^{36}$}

It seems to me that most people ask themselves, one time or another, what sort of society is it in which we live? How can we make sense of what is going on with our world? .... It is, in my view, the duty of social science to identify and explain the most consequential features of how we live now, the better that we may see where we are headed, so that we might influence where we are going. (Webster, 2006, p. 1)

The words of Frank Webster ring a bell in my mind. Indeed, the quest for knowledge, the need to know "what is going on" in the world, motivates social analysts to undertake research. This dissertation emerged from my observations of changes in East African mediascapes: a rise in the number of radio and television stations, the emergence of cross-media ownership, acquisitions of communications firms, the enjoyment of relative media freedom, shifts from public- to private-oriented management in the telecommunications sector, the opening of the telecommunications market to private investors, the establishment of regulatory agencies for national communications sectors, and the formulation of communications policies. I asked myself, Why are these changes occurring? I soon found an answer in liberal scholarship on African communications transformations: the democratization of East Africa since the 1990s has unleashed these changes. At first I took this line of thought for granted and accepted it.

After further reading and analysis of the observable aspects of these changes, I began to develop doubts about liberal thinking on communications transformations. For one thing, the liberal perspective could not explain the link between democratization and market liberalization of telecommunications, the rising tide of reform in national broadcasting sectors, or the creation of communications regulatory agencies. These 
observations led me to believe there were other factors apart from those of democratization that were at work in East Africa, and I sought to locate the external dynamics that were contributing to the evolution of East African communications transformations. I had some knowledge about structural adjustment programmes in Africa, and so I turned my focus to international development organizations.

After reading broadly from the literature on the neoliberal world order, I realized that international development organizations are involved in neoliberalization, global neoliberalism and neoliberal global governance, and I began to give special attention to the World Bank and the United Nations Economic Commission for Africa as prime examples of these organizations. It emerged that the main task of my research was to conceptualize interactions between international development organizations and East African governments within the issue-area of communications. The envisioned theoretical framework was expected to provide a language for talking about the project of economic globalization that these organizations promote. This project involves creating a neoliberal East African mediascape through the practices of neoliberalization, the rationality/ideology of global neoliberalism and the power relationship of neoliberal global governance. I chose the Foucauldian global governmentality perspective because it offers the necessary analytical tools for carrying out this study.

The chosen perspective allows this dissertation to contribute to the study of African communications transformations in two main ways. First, the dissertation has diversified its research approach in order to look beyond analysis of the observable and quantifiable manifestations of communications transformations, which constitute the

\footnotetext{
${ }^{36}$ I have borrowed this chapter's title from Lawrence Grossberg's book, Bringing It All Back Home: Essays on Cultural Studies (Durham, NC: Duke University Press, 1997).
} 
substantive dimension, by bringing on board the calculative, epistemic and ontological dimensions as well. In this dissertation, I have covered the four dimensions of East African communications transformations, but I have given particular emphasis to the calculative and epistemic dimensions. This focus leads to the next contribution: the reconceptualization of global governance outside of the prevailing perspective of the global governance theory of communication. The theoretical clarification of the concept of global governance facilitates thinking about global governance as a phenomenon within the context of economic globalization and East African communications transformations. Further contributions are the methodological proposals: the adoption of an epistemic genealogical perspective in the study of communications transformations; and the revitalization of critical frame analysis as a distinct strand of the frame research method. The chapter also addresses the "so-what" concern by making practical recommendations concerning how to expand the democratization process within East African mediascapes beyond its neoliberal confines, and the reforming of communication education in East African universities.

To sum up, the present chapter identifies six contributions this dissertation makes, which are discussed in the following order: practical contributions-expansion of the democratization process, reforming communications education; theoretical contributions-diversification of research on communications transformations, reconceptualization of global governance; and methodological contributions-adoption of an epistemic genealogical perspective, renewal of critical frame analysis. I conclude the chapter, and indeed the dissertation, by emphasizing that international development 
organizations in conjunction with East African governments have initiated and propelled changes in East African communications transformations.

\section{Expansion of the Democratization Process}

The introductory chapter notes that liberal analysts of African communications transformations along with international development organizations conceptualize democratization in line with the liberal theory of democracy. The liberal perspective views democratization as the process of expanding political rights (or civil liberties, including media freedom), civil rights (equality), and human rights. This basic form of the democratization process conjoined with the international development organizations' project of economic globalization has undermined the democratic values of equity, participation and self-governance within East African mediascapes. Consequently, East African mediascapes suffer from the democratic deficits of loss of self-governance, inadequate redistribution of media resources and deficient participation of citizens. In the following discussion, I elaborate on these democratic deficits and propose possible ways of overcoming them.

\section{Loss of Self-governance}

The Atlantic Charter (August 1941) is the originating document of the democratic value of self-governance. The Charter-a bilateral agreement between American President Franklin D. Roosevelt and British Prime Minister Winston Churchill—was also endorsed in September 1941 by Australia, Belgium, Canada, Czechoslovakia, Greece, Luxembourg, New Zealand, the Netherlands, Norway, Poland, South Africa, the Soviet 
Union, Yugoslavia and the Free French movement of General Charles de Gaulle (Wilson, 1991, p. 226). The Charter's third principle declared that people had a right to govern themselves, and as such, it rejected the denial of self-governance through colonialism ${ }^{37}$ (Roosevelt, 1941, p. 678). The promise of self-governance saw the rise of African liberation movements and the people's fight for independence from their colonial masters, and as a result most of Africa became independent in the 1960s, including the East African countries of Tanganyika in 1961, Uganda in 1962, Kenya in 1963, and Zanzibar also in 1963 (Arnold, 1994, pp. 44-45). In 1964, Tanganyika and Zanzibar amalgamated to form the United Republic of Tanzania. Every year, East Africans commemorate the attainment of self-governance and promise to safeguard it.

I view self-governance in a broader sense that goes beyond the idea of political freedom to include self-governance in economic and epistemic matters as well. Chapters two and four show that East Africans fall short of self-governance in the issue-area of the epistemic foundations of communications policies. Through the practices of neoliberalization, international development organizations have promoted neoliberal knowledge which, by means of particular strategic activities, has transformed East African mediascapes. Drawing from the Foucauldian global governmentality perspective, I have labeled the strategic activities of international development organizations as “calculative practices" of neoliberalization. Chapter two notes that the World Bank has

\footnotetext{
${ }^{37}$ The Atlantic Charter defines eight "common principles for a better world": desistance from occupying the territory of defeated nation-states after World War II; making no changes to territorial borders in the postwar era without approval from citizens; the right of all people to selfgovernance; adherence to free trade - that is, nation-states were expected to open their territories to foreign trade and investment; enhancement of living standards of workers-including health and pension benefits; promotion of peace by all nations so that people "could live their lives in freedom from fear and want"; improvement of security in sea travel; and working towards the
} 
used the calculative practices of corporatization, commercialization and market liberalization to restructure the East African broadcasting sector. The Bank has also applied the calculative practice of performance benchmarking in an effort to reform the telecommunications sector. The World Bank and the United Nations Economic Commission for Africa (among other international development organizations) have utilized the calculative practices of networking and framing in communications policymaking processes in East Africa (chapters two and four), with the result that East Africans have lost epistemic self-governance to international development organizations. Thus, these organizations have violated the people's right to epistemic self-governance in the area of communications policies.

\section{Inadequate Redistribution of Media Resources}

This shortcoming of the changing East African mediascape militates against the democratic value of equity, which was defined in the 1951 Frankfurt Declaration on democratic socialism (Socialist International, 1968 [1951]; Busky, 2000, pp. 7-15). The Declaration emphasized economic democracy in form of redistribution of national resources through collective and private ownership of means of production (Socialist International, 1968 [1951], pp. 284-285). This strategy envisioned a society in which citizens enjoy national resources without a few of them becoming extremely rich while millions languish in poverty. Evaluating East African mediascapes from the perspective of the democratic value of equity is paramount, given that media are national resources that can be used as tools to improve human welfare - to disseminate information, 
promote education, facilitate participation in public debates, and provide income and employment. What emerges, however, from the study of East African mediascapes (in chapter two) is that these national resources are concentrated in very few hands and therefore have become sources of income for the wealthy. The examples of two media giants in East Africa are a case in point: Nation Media Group (Kenya) and Industrial Production Promotion (Tanzania).

Both companies are involved in cross-media ownership in such media sectors as newspapers, magazines and radio and television broadcasting. While Nation Media Group is a shareholding venture, Industrial Production Promotion is the property of a single owner. In line with the expanded conception of "media" as "mediascapes," ownership of the East African telecommunications sector is the preserve of the rich (chapter two). Chapter five presents evidence of the very high number of companies that are being registered in Kenya in readiness to buy public enterprises that are undergoing privatization. As things stand now, wealthy business owners are rapidly buying up recently privatized state-owned telecommunications enterprises in East Africa, while the same or other wealthy individuals, or their multiple registered companies, are ready and waiting to snap up other enterprises as soon as they become available. The best way to ameliorate the situation is for East African governments to enable citizens to own shares-through their cooperative societies, for instance-in community radio projects and privatized state-owned telecommunications enterprises. National governments could incorporate cooperative ownership into communications policies and design programmes to create public awareness about this opportunity. 
Cooperative societies are well established in Kenya, Tanzania and Uganda. For example, Kenya had 10,800 cooperative societies in 2005, with funds amounting to a total of US\$ 1.5 billion (Mudibo, 2005). Thus, the idea of cooperative societies is not new in East Africa-in fact, it dates back to the first decade of the 1900s (Strickland, $1933,1935)$. What is new, though, is the proposal that cooperative societies can own community radio stations and state-owned telecommunications enterprises undergoing privatization. It is important to point out that cooperative ownership within the East African communications sector should coexist with private ownership, and that cooperative societies would own community radio stations but allow a management board to run them, as private firms do. For this proposal to materialize, two things need to be done: cooperative media ownership in contrast to private ownership must be conceptualized and justified; and conceptual clarification of the distinction between cooperative and community radio must be provided. The two tasks could be the startingpoint for public debates on the inclusion of cooperative ownership of media in the East African mediascape. Such an exercise would involve reviewing and revising existing communications policies to ensure that they enable and promote cooperative ownership.

\section{Deficient Participation of Citizens}

East African communications transformations have not benefited from the democratic value of participation for two main reasons: the absence in the media of alternative views on ICT issues, and control of the communications policy-making process by elites. The lack of alternative positions on ICT issues is demonstrated by the following finding: mainstream East African newspapers-the Daily Nation (Kenya), the Daily News (Tanzania) and The New Vision (Uganda)—sidelined ICT civil society organizations in 
2006. As the in-depth analysis of the Daily Nation discussed in chapter five shows, this newspaper not only ignored communications-based civil society organizations in its ICT news reports, but it privileged official sources to the extent that the framing of ICT news in 2006 followed reports issued by the Kenyan government. Thus, the alternative voices of ICT civil society organizations were effectively marginalized.

The other argument on elite-controlled policies revisits the national and international contexts of communications policy-making processes in East Africa. The very notion of an African information society emerged from the global-regional venue of the United Nations Economic Commission for Africa (UNECA) through the recommendations of the High-Level Working Group of eleven information technologists (chapter two). UNECA, along with other international organizations such as the World Bank and the International Telecommunication Union, established the African Information Society Initiative, which was instrumental in shaping the epistemic underpinnings of East African communications policies (chapters two and four).

At the national level, elites-business, technocratic and academic-were at the forefront of communications policy-making processes in East Africa. Kenyan business elites, through the Kenya Private Sector Alliance, organized workshops which, like the African Information Society Initiative, linked information and communication technologies to economic development and highlighted the potential of that link to education, health and other social services. In Tanzania, the eThinkers-a group of elites working for ICT firms-were instrumental in drafting ICT policy. Representatives from the private sector in Tanzania's Task Force on National ICT Policy were all eThinkers. As for Uganda, the academic community and international development technocrats 
shaped the drafting of the ICT policy through the Uganda Information Infrastructure Agenda Project, as prescribed by the African Information Society Initiative. This project is jointly managed by the World Bank, the Ugandan government and Makerere University. In fact, the final policy document was produced in consultation with the Uganda Information Infrastructure Agenda Project and senior personnel in the public and private sectors as well as the Uganda Investment Authority and Perwit International (of Canada).

The preceding discussion underscores the argument that international development organizations in conjunction with East African governments have created East African mediascapes with no significant participation from citizens. Consequently, the emerging East African mediascapes are deficient in the democratic value of participation, which Jurgen Habermas expounds in his theory of the public sphere. Through his historical analysis of the Enlightenment and democratic revolutions in France and the United States, Habermas (1989 [1962]) identified the emergence of a "bourgeois public sphere" that was distinct from the "sphere of public authority." The latter sphere, which existed before the French and American democratic revolutions, was synonymous with the royal courts, which alone discussed and made decisions concerning public affairs (p. 18). Basically, the "sphere of public authority" was an exclusive club of rulers—royalty and the aristocracy—and thus excluded the bourgeoisie.

In the late eighteenth and early nineteenth centuries, the bourgeoisie constituted themselves as an oppositional social class, which formed the "bourgeois public sphere" (Habermas, 1974, pp. 51-52). This sphere was an arena where private individuals of the bourgeois class congregated together as a "public" and discussed issues pertaining to 
them, in particular how the state was governing them and the general public (Habermas, 1989 [1962], pp. 25, 29; 1992, p. 427). Thus, a public sphere creates a democratic space in which citizens constitute themselves as a "public" and can deliberate amongst themselves on issues of importance to them. From a Habermasian perspective, civil society and the media can be viewed as democratic spaces belonging to the public sphere (Habermas, 1974, p. 49; Kellner, 2000, p. 6; Dryzek, 2000, p. 100). It can be argued that the lack of prominence of civil society organizations in national policy-making processes and news coverage of ICT issues in East Africa are indicators of an elite-dominated, not a citizen-driven, public sphere. East Africans have the capacity to open the public sphere as the following section argues.

\section{Transcending Democratic Deficits}

The democratic deficits of East African communications transformations-the deficient participation of citizens, loss of self-governance and inadequate redistribution of media resources-impede entrenchment of the democratic values of participation, selfgovernance and equity as well as the democratization process in general. To reclaim these values, I propose two courses of action: the creation of democratic spaces, and a review of East African communications policies. The former proposal is directed towards increasing participation, while the latter seeks to enhance the democratic values of selfgovernance and equity.

Through civil society organizations, East Africans could strengthen democratization through media by creating democratic spaces that facilitate their deliberations on ICT issues. Essentially, democratization through media involves using media to enhance participation in the democratization process. Civil society organizations 
could open democratic spaces in the form of alternative media—that is, media outlets encouraging participation of citizens and providing different viewpoints from those expressed in mainstream media. They could establish websites, magazines and broadcasting stations that discuss, among other things, the themes of the information society within national, regional and global contexts; and global neoliberalism in relation to the national communications sector. To ensure informed discussion, civil society organizations would need to conduct audits of national mediascapes in the form of analyses of communications institutions and policy as well as media performance on communications-related issues. In this endeavour, civil society organizations could benefit from the examples of mediascape audits presented by this dissertation: an institutional audit of East African mediascapes (chapter two); an audit of national communications policies (chapter four); and a performance audit on the reporting of ICT issues by East Africa's leading regional newspaper-the Daily Nation (chapter five).

The other proposal of reviewing East African communications policies presents more of a challenge because these policies are currently in operation. Hence, revising them would involve pressure from some quarters: herein the focus is on ICT civil society organizations. In order to proceed with the review, the ground would need to be prepared through two preliminary strategies: abandoning the neoliberal conception of ICT civil society organizations, and making democratization of mediascapes a core concern of ICT civil society organizations.

ICT civil society organizations in East Africa operate within the neoliberal view of civil society, which recognizes the coexistence of three spheres of social organization: the state, the market, and civil society (World Bank, 2005, p. 3). In this tripartite 
arrangement, civil society is thought of as including non-governmental and not-for-profit organizations, but not "for-profit-businesses, although professional associations or business federations may be included" (ibid.). This neoliberal conception of civil society includes those organizations that are infiltrated by business interests such as the Kenya ICT Action Network (KICTANet), whose members include associations of business owners-for example, the Kenya ICT Federation and the Media Owners Association. Business federations promote the interests of their members, i.e., their profits, and not the welfare of the general public. Thus, the neoliberal conception of civil society conflicts with the emancipatory conception of civil society organizations as the prime catalysts of resistance against the tendencies of states and entrepreneurs to infringe human rights and to put profits ahead of concerns about human welfare (van der Zweerde, 2006, p. 346).

The other strategy is the incorporation of democratization of mediascapes in the ICT civil society organizations' push for democratization through media. Democratization of mediascapes "comprises efforts to change media messages, practices, institutions and contexts (including state communication policies), in a direction which enhances democratic values and subjectivities, as well as equal participation in societal decision-making" (Hackett, 2000, p. 64). A mediascape democratization project entails auditing mediascapes and identifying democratic deficits within them (Hackett \& Carroll, 2006, p. 1-10). As noted earlier, chapters two, four and five comprise audits of East African mediascapes, and this chapter has highlighted particular democratic deficits. Inclusion of the democratization of mediascapes as a core issue-area for East African ICT civil society organizations would go a long way towards building a case for reviewing national communications policies. This dissertation, therefore, provides knowledge that 
ICT civil society organizations can draw from in calling attention to the democratic deficits of equity, participation and self-governance marring East African communications transformations.

\section{Reforming Communication Education}

This dissertation has identified generative reporting as the guiding form of journalism that underpinned the Daily Nation's coverage of ICT issues in 2006. Generative journalism can be defined as a practice in which journalists identify social problems and offer solutions according to the worldview of particular institutions. Chapter five has shown that the Daily Nation's problematization (or diagnosis and prognosis) of ICT issues followed that of the World Bank and the Kenyan government. ${ }^{38}$

By relying on generative reporting, this newspaper engaged in two main activities. First, it drew from official governmental framing of ICT issues when reporting and analyzing ICT news. Chapter five has attempted to link the Kenya ICT Strategy to the president's speech and ICT news extensions in the Daily Nation. It found that this newspaper sought ICT news largely from official sources. The other activity is that the Daily Nation engaged in ideological work-that is, the exercise of making neoliberal globalism a national-popular rationality/ideology. By promoting market and trade liberalization and privatization through editorials and commentaries, the newspaper has, essentially, involved itself in the ideological work of transforming global neoliberalism from a global- to a national-popular rationality/ideology. This form of ideological promotion is also being carried out by the World Bank and East African governments

\footnotetext{
${ }^{38}$ The notion of generative journalism is more relevant to this study than that of agenda-setting journalism because it goes deeper into investigating the epistemic foundations of news.
} 
with the aim of creating national communications sectors that adhere to market-based policies. The outcome of the Daily Nation's twin activities are that it has tended to shield global neoliberalism from public scrutiny and sideline non-official sources. The two tendencies have contributed to bringing global neoliberalism into the national consciousness as commonsense practical knowledge applicable to Kenya's communications sector.

To rise above the practice of generative reporting, the Daily Nation could engage in what Karim Karim refers to as "conscientious reporting," which has three main characteristics (2003, pp. 175-196). First, this form of journalism involves reporting both the "“negative" and "positive" aspects of the story" (p. 179). From the standpoint of this dissertation, it is recommended that journalists provide information on both the positive and negative implications of trade and market liberalization as well as the privatization of national communications sectors. One way of carrying out this task would be to analyze news from non-official sources-for example, civil society organizations and members of the general public.

The second characteristic is that conscientious journalists attempt to situate "events and processes within their contexts" (ibid). This dissertation has insisted that context matters-it has examined national ICT policies and strategies and ICT news within the global neoliberal context. Conscientious journalists would seek to relate national ICT policies to worldwide trends and the policies of international development organizations. The third characteristic concerns subjectivity: journalists should bear in mind that the tendency to subjectivity can influence their reportage (p. 194). The conventional position is that journalistic objectivity prevents news workers from taking a 
subjective position in news gathering and production. From a critical frame perspective, this dissertation has argued that political rationality/ideology impacts on journalists as they do their work (chapter three). It has also attempted to show that the belief in journalistic objectivity has not prevented the Daily Nation from engaging in the work of promoting global neoliberalism as a national-popular rationality/ideology.

The import of the preceding argument is that the issue of human subjectivity should be given the same weight as that of journalistic objectivity in communication and journalism education. East African universities offering communication and journalism programmes — such as Daystar (Kenya), Nairobi (Kenya), Dar-es-Salaam (Tanzania), St. Augustine (Tanzania), and Makerere (Uganda)—-train students in the presentational skills of news reporting and production, but give little attention to the teaching of representational analysis. ${ }^{39}$ This focus privileges journalistic objectivity, and as such, the role of human subjectivity in journalistic work is sidelined. An example of the journalistic practice of representation is the framing of news. From a critical frame perspective, news production is not a purely objective process because journalists and editors frame an article (that is, organize the material) so as to narrate an occurrence in a particular way (chapter three). Moreover, the worldviews of social institutions such as governments and international development organizations can infiltrate the framing process of news production, as illustrated in chapter five.

This dissertation has highlighted the representational aspect of news production through conceptualizing and analyzing the framing process of news. Thus, it underscores the significance of understanding the representational side of journalistic work alongside

\footnotetext{
${ }^{39}$ I have come to this conclusion after reviewing communication/journalism programmes available on websites belonging to these universities.
} 
the presentational one. In this vein, communication and journalism education in East Africa needs to be expanded to include courses that expose students to both the presentational and representational practices of journalism. Such expanded curricula will prepare students to perform both tasks well; moreover, it will encourage them to engage in research that relates to the journalistic practice of representation. Research methods that are valuable in studying media representation include discourse analysis, narrative analysis, semiotic analysis, and of course, frame analysis.

\section{Diversifying Research on African Communications Transformations}

Since the 1990s, liberal analysts have conceptualized East African communications transformations with special attention to media-government relations and the shift from single-party politics (of the "authoritarian presidency" variant) to multi-party politics (based on liberal democratic theory). Their core assumption is that the media are transforming East African countries into more liberal democratic societies. From a liberal democratic viewpoint, the media are bringing about social change by adopting a watchdog role over government that is premised on "an attitude of mistrust toward government" (Rosenblum, 1995, p. 757). For media to perform that role, governments are expected to guarantee freedom of expression—especially, in the issue-area of news reporting and analysis. Hence, the interest in media freedom among liberal analysts of communication transformations in terms of identifying and seeking ways to transcend bottlenecks that work against the creation and maintenance of a more liberal democratic society. 
By seeking to account for the expansion or contraction of media freedom within a particular nation-state, liberal analysts engage in nation-centric analysis of East African communications transformations. This nation-centric approach gives primacy to examining the implications of national dynamics of change in a country's communications sector. As a result, liberal analysts give little attention to the global dynamics that continue to transform East African mediascapes. In particular, they have failed to study the link between East African communications transformations and international development organizations' project of economic globalization. In this respect, liberal analysts lack a theoretical framework that can conceptualize East African communications transformations within a neoliberal world context. This dissertation has sought to relate these transformations to economic globalization through the study of international development organizations' application of the practices of neoliberalization, the rationality/ideology of global neoliberalism and the power resource of neoliberal global governance.

The dissertation advances a two-fold strategy for transcending problematics within the liberal theory of communication transformations: adopting a broad view of East African communications transformations, and diversifying research in communications transformations beyond media freedom. In support of these strategies, I have argued in chapter one that East African communications transformations can be thought of as comprising four dimensions: calculative, epistemic, ontological and substantive. The dissertation recommends that these dimensions constitute research areas that social analysts can develop into focused studies of communications transformations within and across nation-states. Suggestions for conceptualizing the dimensions are as 
follows: calculative, in terms of actor-network theory-Bruno Latour, Michel Callon; epistemic, through the global governmentality perspective-Michel Foucault, Nikolas Rose, Mitchell Dean, Wendy Larner, and William Walters; ontological, using Martin Hewson's and Timothy Sinclair's ontological approach to global governance, Immanuel Wallerstein's world-system analysis, and Jurgen Habermas's theory of the public sphere; and substantive, following the liberal theory of communications transformations and Harold Innis's civilization perspective. These theoretical frameworks can help social analysts of communications transformations to answer the following question: Why are mediascapes in a particular country or region changing? I have attempted to conceptualize the dimensions of communications transformations, and for the purposes of narrowing this study, analytical weight has been given to the calculative and epistemic aspects.

\section{Re-conceptualizing Global Governance}

I hold that a global governance perspective can help in studying the epistemic dimension of East African communications transformations. However, I dissociate this dissertation from the theoretical positions of two conventional approaches to the global governance theory of communication-cosmopolitan governance and international regime. The main limitation of these two approaches is that they conceptualize global governance as "interstate rules," which have been formulated by state representatives in international organizations. This conception of global governance ignores the fact that the institutional agents of international organizations produce and articulate particular forms of knowledge, and use various practices to ensure that nation-states are adhering to their 
organization's chosen form of knowledge. This dissertation has focused on one group of international organizations-international development organizations-and shown that global neoliberalism is their main knowledge-form. It has also emphasized that these organizations are using the power resource of neoliberal global governance and practices of neoliberalization with the aim of transforming East African states, economies and mediascapes.

In order to conceptualize the international development organizations' project of economic globalization in relation to East African communications transformations, this dissertation has suggested that the conceptual horizon of the global governance theory of communication be expanded. In this regard, I have found the conceptual tools of the Foucauldian global governmentality perspective helpful in relating the calculative and epistemic aspects of East African communications transformations to economic globalization. This perspective aids in conceptualizing economic "globalization as governmentality" in that it is constituted through the calculative practices of neoliberalization, which are based on a particular mode of thought-herein, a rationality/ideology of global neoliberalism-and asymmetrical power relationships between international development organizations and East African governments. Researchers can use the global governmentality perspective to study the calculative and epistemic aspects of communications transformations in the western, southern and central regions of sub-Saharan Africa, as well as in other regions of the global South generally. 


\section{Adopting an Epistemic Genealogical Perspective}

The proposed epistemic genealogical perspective is a research orientation that directs attention to how institutions articulate problematizations of social life. The perspective is based on the Foucauldian conceptual tool of "programmes of governance," which refers to texts such as policies, budgets, party manifestos, and election pledges. This dissertation has evaluated the following programmes of governance that relate to East African communications transformations: the African Information Society Initiative (chapter two); the World Bank's funding of privatization projects and ICT policy for developing countries (chapters two and four); the communications policies of East African governments (chapter four); and Kenya's strategy document on the application of ICT for development (chapter five).

The perspective claims that programmes of governance emerge from prior problematizations of social life. The problematization process involves the identification of a social problem and the framing of a solution, a way of thinking that corresponds to the basic definition of policy as a strategy aiming "to solve problems so that some measure of uncertainty can be reduced" (Birkland, 2005, p. 126). The task, therefore, of an epistemic genealogist is to revisit the problematization of programmes of governance and unearth their diagnostic and prognostic strategies. This exercise can help to unveil the core assumptions of programmes of governance that underpin the prognosis of a particular social problem. The perspective, through the research method of critical frame analysis, has facilitated analysis of the World Bank's documents in relation to East African communications policies (chapter four), and evaluation of the Daily Nation's coverage of ICT issues within the neoliberal world order (chapter five). This research 
orientation can be useful in the analysis of communications policies and news reports related to policy debates such as election campaigns and public hearings.

\section{Demarcation of Critical Frame Analysis}

The epistemic genealogical perspective (discussed above) is a research orientation and, as such, it needs to be augmented with a research method. For this dissertation, I chose critical frame analysis as the preferred research method. By utilizing a methodological perspective of social sciences, I have been able to reconstruct critical frame analysis as a distinct method within the broader area of frame research studies. Critical frame analysis can be characterized as a research method that facilitates analysis of media frames outside the media effects tradition, study of the media-side of media-movement interactions, and examination of the role of ideology in the framing process of news. The reconstruction of critical frame analysis refines one of the strands of frame studies, and in turn, contributes to the methodological clarity of a mass communication research method.

Moreover, the dissertation contributes to critical frame analysis in two main ways: by adopting the "core framing tasks" of interpretive frame analysis as data collection tools, and by drawing from Michel Foucault's critical insights in the interpretation of data. Researchers can use critical frame analysis to study the epistemic dimension of communications transformations, particularly in conducting comparative analyses of national ICT policies and policy positions of international development organizations, and in analyzing ICT news in relation to ICT policies of nation-states or international development organizations. 


\section{Final Remarks}

This dissertation can be viewed as an analysis of the power relations embedded in East African communications transformations. It has attempted to foreground the power relations between international development organizations and East African governments within the issue-area of communications transformations. More specifically, the dissertation has sought to show how international development organizations have transformed East African mediascapes through their projects of economic globalization. The World Bank's key text on economic globalization-Globalization, Growth and Poverty (2002b) - views economic globalization as a natural, spaceless and abstract phenomenon. This way of thinking conceals the role of power relations and the active part human beings play in the process.

The introductory chapter has argued that economic globalization is a human creation, spatial phenomenon and networking project. By viewing economic globalization in this way, the dissertation foregrounds the human and geographical aspects of the phenomenon as well as the significance of examining the power dynamics articulated through it. This alternative characterization of economic globalization is liberating in the sense that it does not take for granted the phenomenon and its implication in East African communications transformations.

The foregoing alternative worldview to economic globalization leads to the argument that the global dynamics of neoliberal global governance, global neoliberalism and neoliberalization are human creations. This dissertation has attempted to link the dynamics of economic globalization to international development organizations, and to show how these organizations have used the dynamics to transform East African 
mediascapes. Thus, East African communications transformations are not natural phenomena but creations of institutional agents of international development organizations along with East African governments.

Emanating from this alternative worldview is an emancipatory mode of thinking: humans can re-create what they have created if it fails to improve their well-being. This dissertation has emphasized that the current policy frameworks for East African mediascapes have failed to enhance the welfare of East Africans. It has found that national communications policies are undermining the democratic values of equity, participation and self-governance, and as such, the resultant mediascapes are promoting inequity in society. The proposed way out of this quandary is to "create" new policies that respect these values. The task ahead is to convince East African governments that national communications policies are undercutting the democratic values of equity, participation and self-governance. This is where civil society organizations come in. These organizations can step forward and take up the challenge of ensuring the restoration of equity, participation and self-governance in East African mediascapes. Such a move would boost the chances for creating a more humane and egalitarian East African communications sector. This dissertation is an epistemic contribution to such a social movement. 


\section{References}

Aberle, D. F. (1966). The Peyote religion among the Navaho. Chicago: Aldine.

Adam, L. (2006). Particpation of developing countries in the World Summit on the Information Society (WSIS) process: Kenya case study. Johannesburg, South Africa: Association for Progressive Communications.

Africa Online. (2007). Our history. Retrived February 12, 2007 from http://www.africaonline.com/about.php/id +5

African Women's Development and Communication Network. (2007). About us: Background \& history. Retrived November 3, 2007 from http://www.femnet.or.ke/subsection-asp?ID=1

Aga Khan Fund for Economic Development. (2006). [Brochure]. Retrieved November 15, 2007 from http://www.akdn.org/agency/akfed.html

Akhavan-Majid, R. \& Ramaprasad, J. (1998). Framing and ideology: A comparative analysis of U.S. and Chinese newspaper coverage of the Fourth United Nations Conference on Women and the NGO Forum. Mass Communication \& Society, $1(3 / 4), 131-152$.

Alasuutari, P. (1995). Researching culture: Qualitative method and cultural studies. Thousand Oaks, CA: Sage.

American Pyschological Association. (2007). APA dictionary of psychology. (G. R. VandenBos, Ed.). Washington, D.C.: American Psychological Association.

Amoako, K. Y. (2003 [1996]). Foreword. In United Nations Economic Commission for Africa, African Information Society Initiative (AISI): An action framework to build Africa's information and communication infrastructure (pp. 5-6). Addis Ababa, Ethiopia: United Nations Economic Commission for Africa. Retrieved February 10, 2007 from http://www.uneca.org/aisi/docs/AISIBrochure.pdf.

Ainslie, R. (1966). The press in Africa: Communications past and present. London: Victor Gollancz.

Alleyne, M. D. (1995). International power and international communication. New York: St. Martin's Press.

Appadurai, A. (1996). Modernity at large: Cultural dimensions of globalization. Minneapolis, MN: University of Minnesota Press.

Arid Lands Information Network. (2007). About us. Retrived November 3, 2007 from http://www.alin.or.ke 
Arnold, G. (1994). The third world handbook. Chicago: Dearborn.

Asante, C. E. (1997). Press freedom and development: A research guide and selected bibliography. Westport, CT: Greenwood Press.

Association for Progrssive Communications. (2002). Mobilizing African civil society around the importance of ICT policy for the development of the continent. Johannesburg, South Africa: Assocaition for Progressive Communications. . (2006). Kenya: ICT lobbying pays off. Retrieved March 2, 2007 from http://www.rights.apc.org/africa/index.shtml?apc=n2183e_2\&x=4031350

Association for Progressive Communications \& Third World Initiative. (2007). Global information society watch 2007. de la Ley, Uruguay: Moncromo.

Balota, D. A \& Cortese, M. J. (2000). Cognitive psychology: Theories. In A. E. Kazdin (Ed.), Encyclopedia of psychology, volume 2 (pp. 153-158). Washington, D.C.: American Psychological Association.

Bantimaroudis, P. \& Ban, H. (2003). Covering the crisis in Somalia: Framing choices by The New York Times and The Manchester Guardian. In S. D. Reese, O. H. Gandy \& A. E. Grant (Eds.), Framing public life: Perspectives on media and our understanding of the social world (pp. 175-184). Mahwah, NJ: Lawrence Erlbaum.

Barry, A., Osborne, T. \& Rose, N. (Eds.). (1996). Foucault and political reason: Liberalism, neo-liberalism and rationalities of government. Chicago: University of Chicago Press.

Bateson, G. (1972 [1955]). A theory of play and fantasy. In G. Bateson, Steps to an ecology of mind: Collected essays in anthropology, psychiatry, evolution, and epistemology (pp. 177-193). San Francisco: Chandler.

Benford, R. D. (1997). An insider's critique of the social movement framing perspective. Sociological Inquiry, 67(4), 409-430.

Benford, R.D. \& Hunt, S. A. (1992). Dramaturgy and social movements: The social construction and communication. Sociological Inquiry, 62(1), 36-77.

Bennett, T., Martin, G., Mercer, C., \& Woollacott, J. (1981). Class, culture and hegemony: Antonio Gramsci. In T. Bennett, G. Martin, C. Mercer, \& J. Woollacott (Eds.), Culture, ideology and social process (pp. 187-218). London: B.T. Batsford.

Bentham, J. (1995 [1787]). The panopticon writings. Ed. M. Bozovic. New York: Verso. 
Bhatta, G. (2006). International dictionary of management and governance. New York: M. E. Sharpe.

Birkland, T. A. (2005). An introduction to the policy process: Theories, concepts, and modes of public policy making (2nd ed.). New York: M. E. Sharpe.

Blaikie, N. (2000). Designing social research. Malden, MA: Polity Press. . (1993). Approaches to social enquiry. Cambridge, UK: Polity Press.

Blumer, K. (1955). Collective behaviour. In A. M. Lee (Ed.), Principles of sociology (pp. 166-222). New York: Barnes \& Noble.

Boas, N. K. (2000). Press and politics: The Tanzanian experience. In R. T. M'Mbayo, C. Onwumechili, \& R. N. Nwanko (Eds.), Press and politics in Africa (pp. 269-285). New York: Edwin Mellen.

Bourgault, L. (1995). Mass media in sub-Saharan Africa. Bloomington and Indianapolis: Indian University Press.

Bridge, G. (1997). Mapping the terrain of time-space compression: Power networks in everyday life. Society and Space, 15(5), 611-626.

Brinkley, D. \& Facey-Crowther, D. R. (Eds.). (1994). The Atlantic Charter. New York: St Martin's Press.

British Broadcasting Corporation. (2005). Africa's fourth estate. Retrieved January 20, 2007 from http://www.bbc.co.uk/radio4/africasfourthestate/pip/udaw5/

Brown, C. (2002). Sovereignty, rights and justice: International political theory today. Malden, MA: Blackwell.

Burchell, G., Gordon, C. \& Miller, P. (Eds.). (1991). The Foucault effect: Studies on governmentality. London: Harvester Wheatsheaf.

Burgess, S. F. (2004). Structural adjustment and economic reform. In P. J. Kaiser \& F. W. Okumu (Eds.), Democratic transitions in East Africa (pp. 120-141). Burlington, VT: Ashgate.

Busky, D. F. (2000). Democratic socialism: A global survey. Westport, CT: Praeger.

Callon, M. (1986). Some elements of a sociology of translation. In J. Law (Ed.), Power, action and belief: A new sociology of knowledge (pp. 196-229). Boston: Routledge \& Kegan Paul. 
. (1991). Techno-economic networks and irreversibility. In J. Law (Ed.), A sociology of monsters: Essays on power, technology and domination (pp. 133161). New York: Routledge.

Carrage, K. M. \& Roefs, W. (2004). The neglect of power in recent framing research. Journal of Communication, 54(2), 214-233.

Cameron, W. B. (1966). Modern social movements: A sociological outline. New York: Random House.

Celtel International. (2007). News and media. Retrieved January 8, 2007 from http://www.celtel.com/en/news/press_release.html

Centre for the Study of Global Governance. (2005). Our mission. Retrieved October 30, 2005 from http://www.Ise.ac.uk/Depts/global/

Chantrell, G. (2002). The Oxford dictionary of word histories. Oxford, UK: Oxford University Press.

Chomsky, N. (1989). Necessary illusions: Thought control in democratic societies. Montreal, Quebec, Canada: C.B.C. Enterprises.

Commission on Global Governance. (1995). Our global neighbourhood. New York: Oxford University Press.

Communications Commission of Kenya. (2007). Statistics. Retrieved February 17, 2007 from http://www.cck.go.ke/statistics/

Cox, R. W. (1980). The crisis of world order and the problem of international organization in the 1980s. International Journal 35(2), 370-395.

Cox, C. R. (2004). The media reform movement and global media concentration. In P. Phillips \& Project Censored, Censored 2005: The top 25 censored stories (pp. 335-341). New York: Seven Stories.

Craig, R. T. (1999). Communication theory as a field. Communication Theory, 9(2), 119-161.

Curran, J. (2002). Media and the making of British society, c. 1700-2000. Media History 8(2), 135-154.

Curran, J., \& Seaton, J. (1997). Power without responsibility: The press and broadcasting in Britain. London: Routledge.

D'Angelo, P. (2002). News framing as a multiparadigmatic research program: A response to Entman. Journal of Communication, 52(4), 870-888. 
Daniels, W. J. (1995). Civil rights. In S. M. Lipset (Ed.), The encyclopedia of democracy (pp. 231-234). Washington, D.C.: Congregational Quarterly.

Davidson, R. (2006). "An insider's game”: Framing media mergers in France and the United States. International Communication Gazette, 68(4), 331-346.

Dean, M. (1999). Governmentality: Power and rule in modern society. Thousand Oaks, CA: Sage.

de Goede, M. (Ed.). (2006). International political economy and poststructural politics. New York: Palgrave Macmillan.

Department for International Development-United Kingdom. (2006). Influencing policy: The experience of CATIA. London: Department for International Development.

de Vreese, C. H. (2003). Framing Europe: Television news and European integration. Amsterdam: Aksant Academic Publishers.

de Vreese, C. H., Peter, J. \& Semetko, H. A. (2001). Framing politics at the launch of the Euro: A cross-national comparative study of frames in the news. Political Communication, 18(2), 107-122.

Dicken, P., Kelly, P. F., Olds, K. \& Yeung, H. W-C. (2001). Chains and networks, territories and scales: Towards a relational framework for analyzing global economy. Global Networks, 1(2), 89-112.

Dickerson, D. L. (2003). Framing “political correctness": The New York Times' tale of two professors. In S. D. Reese, O. H. Gandy \& A. E. Grant (Eds.), Framing public life: Perspectives on media and our understanding of the social world (pp. 163-174). Mahwah, NJ: Lawrence Erlbaum.

Dryzek, J. S. (2000). Deliberative democracy and beyond: Liberals, critics, contestations. New York: Oxford University Press.

du Gay, P. (1997). Introduction. In P. du Gay, S. Hall, L. Janes, H. Mackay \& K.

Negus. Doing cultural studies: The story of Sony Walkman (pp. 1-5). London, UK: Sage.

Durham, F. D. (2003). Breaching powerful boundaries: A postmodern critique of framing. In S. D. Reese, O. H. Gandy \& A. E. Grant (Eds.), Framing public life: Perspectives on media and our understanding of the social world (pp. 123-136). Mahwah, NJ: Lawrence Erlbaum.

East African Community. (1972). The East African Community: A handbook. Arusha, Tanzania: East African Community. 
. (2007). History. Retrieved May 16, 2007 from http://www.eac.int/history.htm

Econ One Research, Inc. \& ESG International (2002). Uganda telecommunications: A case study in the private provision of rural infrastructure. Los Angeles: Econ One Research, Inc.

Elden, S. (2007). Governmentality, calculation, territory. Society and Space, 25(3), 562-580.

Eldon, M. (2005). Mainstreaming ICTs: Private sector sway. In F. Etta \& L. Elder (Eds.), At the crossroads: ICT policymaking in East Africa (pp. 44-55). Nairobi, Kenya: East African Education Publishers. Retrieved January 25, 2007 from http://www.idrc.ca/openebooks/219-8/\#page_44.

Entman, R. M. (1993). Framing: Toward clarification of a fractured paradigm. Journal of Communication, 43(4), 51-8.

Eribo, F., \& Jong-Ebot, W. (Eds.). (1997). Press freedom and communication in Africa. Trenton, NJ: Africa World Press.

eThinkTank-Tanzania. (2000). Information document. Dar es Salaam, Tanzania: eThinkTank-Tanzania. Retrieved May 13, 2007 from http://www.ethinktank\%20Information\%20Document.pdf. (2007). Who we are (and what we're doing). Retrieved May 13, 2007 from http://www.ethinktank.org/esecretariat/whoweare.htm.

Fairclough, N. (2003). Analyzing discourse: Textual analysis for social research. London: Routledge.

Fay, B. (1975). Social theory and political practice. London: George Allen \& Unwin. (1987). Critical social science: Liberation and its limits. Cambridge, UK: Polity.

Fisher, K. (1997). Locating frames in the discursive universe. Sociological Research Online, 2(3), 1-34.

Food and Agriculture Organization of the United Nations. (1946). Documents relating to the first session of the Food and Agriculture Conference of the United Nations. London: H. M. Stationery Office.

Forgacs, D. (1988). Glossary of key terms. In D. Forgacs (Ed.), A Gramsci reader: Selected writings, 1915-1935 (pp. 420-431). London: Lawrence \& Wishart. 
Foucault, M. (1970). The order of things: An archeology of the human sciences. London: Tavistock.

(1977). Discipline and punish: The birth of the prison.( A. Sheridan, Trans.). New York: Pantheon Books.

(1980). Power/ knowledge: Selected interviews and other writings, 1972-1977. (C. Gordon, Ed.). (C. Gordon, L. Marshall, J. Mepham \& K. Soper, Trans.) New York: Pantheon Books.

. (1983). Afterword: The subject and power. In H. L. Dreyfus \& P. Rabinow (Eds.), Michel Foucault: Beyond structuralism and hermeneutics (2nd ed., pp. 208-226). Chicago: University of Chicago Press.

(1984a). Truth and power. In P. Rabinow (Ed.), The Foucault reader (pp. 5175). New York: Pantheon Books.

. (1984b). Polemics, politics, problematization-An interview with Michel Foucault. In P. Rabinow (Ed.), The Foucault reader (pp. 381-390). New York: Pantheon Books.

(1988). Practicing criticism. In L. D. Kritzman (Ed.), Michel Foucault: Politics, philosophy, Culture-Interviews and other writings, 1977-1984 (pp. 152-156). New York: Routledge.

. (1991a [1978]). Governmentality. In G. Burchell, C. Gordon \& P. Miller (Eds.), The Foucault effect: Studies on governmentality (pp. 87-104). London: Harvester Wheatsheaf.

(1991b). Questions of method. In G. Burchell, C. Gordon \& P. Miller (Eds.), The Foucault effect: Studies on governmentality (pp. 73-86). London: Harvester Wheatsheaf.

. (1991c). The subject, knowledge, and the "history of truth". In M. Foucault, Remarks on Marx: Conversations with Duccio Trombadori (pp. 43-82).

New York: Semiotext(e).

(1991d). Adorno, Horkheimer, and Marcuse: Who is a "negator of history"? In M. Foucault, Remarks on Marx: Conversations with Duccio Trombadori (pp. 115129). New York: Semiotext(e).

(1997). What is critique? In M. Foucault, The politics of truth (pp. 23-82).

New York: Semiotext(e). 
Gamson, W. A. (1992). Talking politics. New York: Cambridge University Press. (1996). Media discourse as a framing resource. In A. N. Crigler (Ed.), The psychology of political communication (pp. 111-132). Ann Arbor, MI: University of Michigan Press.

Gamson, W. A. \& Modigliani, A. (1989). Media discourse and public opinion on nuclear power: A constructionist approach. American Journal of Sociology, 95(1), 1-37.

Gan, F., Teo, J. L., \& Detenber (2005). Framing the battle for the White House: A comparison of two national newspapers' coverage of the 2000 United States Presidential Election. International Communication Gazette, 67(5), 441-467.

Gandy, O. H. (2003). Epilogue-Framing at the horizon: A retrospective assessment. In S. D. Reese, O. H. Gandy \& A. E. Grant (Eds.), Framing public life: Perspectives on media and our understanding of the social world (pp. 355-378). Mahwah, NJ: Lawrence Erlbaum.

Gandy, O., Kopp, K., Hands, T., Frazer, K., \& Phillips, D. (1997). Race and risk: Factors affecting the framing of stories about inequality, discrimination, and just plain bad luck. Public Opinion Quarterly, 61(1), 158-182.

Gill, S. (2003). Power and resistance in the new world order. New York: Palgrave Macmillan.

Gitlin, T. (1972 [1969]). Sixteen notes on television and the movement. In G. A. White \& C. Newman (Eds.), Literature in revolution (pp. 335-366). New York: Holt, Rinehart \& Winston.

(1977). Spotlights and shadows: Television and the culture of politics. College English, 38(8), 789-801.

. (1979). Prime time ideology: The hegemonic process in television entertainment. Social Problems, 26(3), 251-266.

. (1980). The whole world is watching: Mass media in the making \& unmaking of the New Left. Berkeley: University of California Press.

Goeddertz, T. \& Kraidy, M. M. (2003). The "Battle in Seattle": U.S. prestige press framing of resistance to globalization. In L. Artz \& Y. R. Kamalipour (Eds.), The globalization of corporate media hegemony (pp. 79-92). New York: State University of New York Press.

Goffman, E. (1974). Frame analysis. New York: Herbert \& Row. 
Gordon, C. (1991). Governmental rationality: An introduction. In G. Burchell, C. Gordon \& P. Miller (Eds.), The Foucault effect: Studies on governmentality (pp. 1-51). London: Harvester Wheatsheaf.

Government of Kenya. (1965). African socialism and its application to planning in Kenya. Nairobi, Kenya: Government Printer.

(1996). Kenya's economic reforms for 1996-1998. Nairobi, Kenya: Government Printer.

. (2006a). National information \& communications technology

(ICT) policy. Nairobi, Kenya: Ministry of Information and Communications.

. (2006b). Kenya information communications bill. Nairobi Kenya:

Government Printers

(2006c). 2006 Kenya ICT strategy: Collaboration \& outsourcing for economic growth. Nairobi, Kenya: Government Printers.

(2006d). Guidelines to Kenya information communications bill. Nairobi, Kenya: Ministry of Information and Communication

Government of Tanzania. (2003). National information and communications technologies policy. Dar-es-Salaam, Tanzania: Ministry of Communications and Transport.

(2006). Universal communications access act. Dar-es-Salaam, Tanzania: Ministry of Communications and Transport.

Government of Uganda. (2003). National information and communication technology policy framework. Kampala, Uganda: Ministry of Works, Housing and Communications.

. (2004). Brief guide to investing in Uganda. Retrieved January 7, 2007 from http://www.ugandainvest.com/uia2.php?uhpl=guide\&\&uhpl1=Guide

. (2006). National ICT master plan. Kampala, Uganda: Ministry of Information and Communications.

Gramsci, A. (1971). Selections from the prison notebooks of Antonio Gramsci.

(Q. Hoare \& G. N. Smith, Trans. and Eds.). New York: International Publishers.

Griffin, E. A. (1997). A first look at communication theory (3rd ed.). New York: McGraw-Hill.

Grossberg, L., Wartella, E., Whitney, D. C., \& Wise, J. M. (2006). Mediamaking: Mass media in a popular culture (2nd ed.). Thousand Oaks, CA: Sage. 
Habermas, J. (1974). The public sphere: An encyclopedia article. New German Critique, $1(3), 49-55$.

. (1989 [1962]). The structural transformation of the public sphere: An inquiry into a category of bourgeois society. (T. Burger \& F. Lawrence, Trans.). Cambridge, MA: MIT Press.

. (1992). Further reflections on the public sphere. In C. Calhoun (Ed.), Habermas and the public sphere (pp. 421-461). Cambridge, MA: MIT Press.

Hackett, R. A. (1984). Decline of a paradigm? Bias and objectivity in news media studies. Critical Studies in Mass Communication, 1(3), 229-259.

(2000). Taking back the media: Notes on the potential for a communicative democracy movement. Studies in Political Economy, 63, 61-86.

Hackett, R. A. \& Carroll, W. K. (2006). Remaking media: The struggle to democratize public communication. New York: Routledge.

Hackett, R. A., Gruneau, R., Gutstein, R., Gibson, T. A. \& NewsWatch Canada (2000). The missing news: Filters and blind spots in Canada's Press. Aurora, Ontario, Canada:Garamond.

Hackett, R. A. \& Zhao, Y. (1996). Are ethics enough? "Objective" journalism versus sustainable democracy. In V. Alia, B. Brennan \& B. Hoffmaster (Eds.), Deadline $\&$ diversity: Journalism ethics in a changing world (pp. 44-58). Halifax, Nova Scotia: Fernwood.

Hall. S. (1977a). Re-thinking the "base-superstructure" metaphor. In J. Bloomfield (Ed.), Papers on class, hegemony and party (pp. 43-72). London: Lawrence and Wishart.

. (1977b). Culture, the media and the "ideological effect". In J. Curran, M. Gurevitch \& J. Woollacott (Eds.), Mass communication and society (pp. 315348). London: Edward Arnold.

. (1982). The rediscovery of "ideology": Return of the oppressed in media studies. In M. Gurevitch, T. Bennett, J. Curran \& J. Woolacott (Eds.), Culture, society and the media (pp. 56-90). New York: Methuen.

. (1983). The problem of ideology-Marxism without guarantees. In B. Matthew (Ed.), Marx: A hundred years on (pp. 57-85). London: Lawrence \& Wishart.

. (1988). The toad in the garden: Thatcherism among the theorists. In C. Nelson \& L. Grossberg (Eds.). Marxism and the interpretation of culture (pp. 35-57).

Urbana \& Chicago: University of Illinois Press. 
(1989). Ideology. In E. Barnouw, G. Gerbner, W. L. Schramm, T. L. Worth \& L. Gross (Eds.), International encyclopedia of communications, volume 2 (pp. 307311). New York: Oxford Univeristy Press.

(1997). The centrality of culture: Notes in the revolutions of our time. In K. Thompson (Ed.), Media and cultural regulation (pp. 207-238). London: Sage.

Hamelink, C. J. (1994). The politics of world communication: A human rights perspective. London: Sage.

Hazzlewood, A. (1975). Economic integration: The East African experience. London: Heinemann.

Heath, C. W. (1990). Private sector participation in public service broadcasting: The case of Kenya. In L. J. Martin \& R. E. Hiebert (Eds.), Current issues in international communication (pp. 74-81). New York: Longman.

. (1992). Structural changes in Kenya's broadcasting system: A manifestation of presidential authoritarianism. International Communication Gazette, 50(1), 37-51.

(1997). Communication and press freedom in Kenya. In F. Eribo \& W. Jong-Ebot (Eds.), Press freedom and communication in Africa (pp. 29-50). Trenton, NJ: African World Press.

Heilman, B. \& Ndambaro, L. (2004). International context. In P. J. Kaiser \& F. W. Okumu (Eds.), Democratic transitions in East Africa (pp. 142-163). Burlington, VT: Ashgate.

Held, D. (1980). Introduction to critical theory: Horkheimer to Habermas. Berkeley: University of California Press.

Held D. \& McGrew, A. (Eds.). (2002a). Introduction. In D. Held \& A. McGrew (Eds.), Governing globalization: Power, authority and global governance (pp. 1-21). Cambridge, UK: Polity Press. . (2002b). Globalization/Anti-globalization. Cambridge, UK: Polity.

Hertog, J. K. \& Mcleod, D. M. (2003). A multiperspectival approach to framing analysis: A field guide. In S. D. Reese, O. H. Gandy \& A. E. Grant (Eds.), Framing public life: Perspectives on media and our understanding of the social world (pp. 139161). Mahwah, NJ: Lawrence Erlbaum. 
Hewson, M. (1999). Did global governance create informational globalism? In M. Hewson \& T. J. Sinclair (Eds.), Approaches to global governance theory (pp. 97-115). New York: State University of New York.

Hewson, M. \& Sinclair, T. J. (1999). The emergence of global governance theory. In M. Hewson \& T. J. Sinclair (Eds.), Approaches to global governance theory (pp. 322). New York: State University of New York.

Highway Africa. (2005). Absent voices, missed opportunites. Grahamstown, South Africa: Rhodes University's Department of Journalism and Media Studies.

Hills, J. (1996). The silent crisis: Debt and Africa. In G. Gerbner, H. Mowlana, \& H.I. Schiller (Eds.), Invisible crises: What conglomerate control of media means for America and the world (pp. 229-248). Boulder, CO: Westview Press.

Hunt, A. (2004). Getting Marx and Foucault into bed together! Journal of Law and Society, 31(4), 592-609.

Hunt, A. \& Purvis, T. (1993). Discourse, ideology, discourse, ideology. British Journal of Sociology, 44(3), 473-99.

Hyden, G. \& Leslie, M. (2002). Communications and democratization in Africa. In G. Hyden, M. Leslie, \& F. L. Ogundimu (Eds.), Media and democracy in Africa (pp. 1-27). New Brunswick, NJ: Transaction Publishers.

Hyden, G. \& Okigbo, C. (2002). The media and the two waves of democracy. In G. Hyden, M. Leslie, \& F. L. Ogundimu (Eds.), Media and democracy in Africa (pp. 29-53). New Brunswick, NJ: Transaction Publishers.

Industrial Production Promotion. (2004). Structure. Retrieved March 23, 2007 from http://www.ippholdings.com/strcuture.html

International Telecommunication Union. (2003). World telecommunication indicator database. Geneva, Switzerland: International Telecommunication Union. . (2005). Yearbook of statistics: Telecommunication services chronological time series, 1994-2003. Geneva, Swizerland: International Telecommunication Union.

International Y2K Cooperation Center. (2000). Y2K: Starting the century right! Washington, DC; International Y2K Cooperation Center. Retrieved May 1, 2007 from http://www.governmentfutures.com/document/Y2KStartingtheCentury Right-Feb2000.pdf.

Iyengar, S. (1991). Is anyone responsible? How television frames political issues. Chicago: University of Chicago. 
Jessop, B. (2002). The future of the capitalist state. Cambridge, UK: Polity.

Johnston, D. H. (Ed.). (2003). Encyclopedia of international media and communications. San Diego, CA: Academic Press.

Jones, A. (2006). Dictionary of globalization. Malden, MA: Polity Press.

Kaiser, P. J. \& Okumu, F. W. (2004). The challenges of democratic transition in East Africa. In P. J. Kaiser \& F. W. Okumu (Eds.), Democratic transitions in East Africa (pp. 1-12). Burlington, VT: Ashgate.

. (2004). Timeline of key historical events. In P. J. Kaiser \& F. W. Okumu (Eds.), Democratic transitions in East Africa (pp. 183-207). Burlington, VT: Ashgate.

Karim, K. H. (2003). Islamic peril: Media and global violence (updated edition). New York: Black Rose Books.

Karn, M. P. \& Mingst, K. A. (2004). International organizations: The politics and processes of global governance. Boulder, CO: Lynne Rienner.

Kasoma, F. P. (1997). Press freedom in Zambia. In Eribo, F., \& Jong-Ebot, W. (Eds.). Press freedom and communication in Africa (pp. 135-156). Trenton, NJ: Africa World Press. . (2000). The press and multiparty politics in Africa.

Unpublished Ph.D. dissertation, University of Tampare, Tampare, Finland.

Kellner, D. (2000). Habermas, the public sphere, and democracy: A critical intervention. Retrieved November 12, 2007 from http://www.gseis.ucla.ed/faculty/kellner/ essays.html

Kendall, G. (2004). Global networks, international networks, actor networks. In W. Larner \& W. Walters (Eds.), Global governmentality: Governing international spaces (pp. 59-75). New York: Routledge.

Kenya ICT Action Network. (2007). About us. Retrieved February 2, 2007 from http://www.kictanet.or.ke/index.php?option=com_content\&task=view\&id= $5 \&$ Itemid $=6$

Keohane, R.O., \& Nye, J. S. (1989). Power and interdependence. New York: HarperCollins.

Kozolanka, K. (2003). Political communication and construction of the neoliberal hegemonic project: Ontario in transition, 1995-1997. Unpublished Ph.D. dissertation, Carleton University, Ottawa, Ontario, Canada. 
Krasner, S. D. (1983). Structural causes and regime consequences: Regimes as intervening variables. In Krasner, S. D. (Ed.), International regimes (pp. 1-21). New York: Cornell University Press.

Kunczik, M. (1988). Concepts of journalism; North and south. Bonn, Germany: Friedrich-Ebert Stiftung.

Larner, W. (1997). The "New Zealand experiment": Towards a post-structuralist political economy. Unpublished Ph.D. dissertation, Carleton University, Ottawa, Ontario, Canada.

. (2000). Neoliberalism: Policy, ideology, governmentality. Studies in Political Economy, 63, 5-23.

. (2002). Globalization, governmentality and expertise: Creating a call centre labour force. Review of International Political Economy, 9(4), 650-674.

Larner, W. \& Butler, M. (2005). Governmentalities of local partnerships: The rise of a "partnering state" in New Zealand. Studies in Political Economy, 75, 79-101.

Larner, W. \& Le Heron, R. (2002). From economic globalization to globalizing economic processes: Towards post-structural political economies. Geoforum, 33(3), 415-419.

Larner, W. \& Walters, W. (Eds.). (2004a). Global governmentality: Governing international spaces. New York: Routledge.

. (2004b). Global governmentality. In W. Larner \& W. Walters (Eds.), Global governmentality: Governing international spaces (pp. 1-20).

New York: Routledge.

. (2004c). Globalization as governmentality. Alternatives, 29(5), 495-514.

Latour, B. (1986). Visualization and cognition: Thinking with eyes and hands. Knowledge and Society: Studies in the Sociology of Culture, Past and Present, $6,1-40$.

Law, J. \& Hetherington, K. (1999). Materialities, spatialities, globalities.

Centre for Science Studies, Lancaster University. Retrieved August 21, 2007 from http://www.comp.lancs.ac.uk/sociology/papers/Law_Hetherington_Materialities_ Spatialities_Globalities.pdf.

Lederbogen, U. (1992). Watchdog or missionary? A portrait of African news people and their work-A case study in Tanzania. Frankfurt am main, Germany: Peter Lang. 
Lee, S. (1999). International political economy: Major contemporary themes. In P. A. O'Hara (Ed.), Encyclopedia of political economy, vol. 1 (pp. 574-577). New York: Routledge.

Le Heron, R. (2007). Globalization, governance and post-structural political economy: Perspectives from Australasia. Asia Pacific Viewpoints, 48(1), 26-40.

Lippman, W. (1922). Public opinion. New York: Macmillan.

Littlejohn, S. W. (1996). Theories of human communication. Belmont, CA: Wadsworth.

Littlejohn, S. W. \& Foss, K. A. (2005). Theories of human communication (8th ed.). Belmont, CA: Thomas Wadsworth.

Lukalo-Owino, R., Wambui, M. \& Butegwa, C. (2006). Strengthening Africa's media: Towards a framework for action. Nairobi, Kenya: Africa Women's Development Network.

Mabry, E. A. (2003). Textual framing as a communication climate factor in online groups. In S. D. Reese, O. H. Gandy \& A. E. Grant (Eds.), Framing public life: Perspectives on media and our understanding of the social world (pp. 323-336). Mahwah, NJ: Lawrence Erlbaum.

Mackay, H. \& Reynolds, P. (2001). Researching the information society: Methods and methodologies. In H. Mackay, W. Maples \& P. Reynolds, Investigating the information society (pp. 53-66). New York: Routledge.

Macionis, J. J. \& Gerber, L. M. (2004). Sociology. Toronto, Ontario, Canada: Pearson Education Canada.

Maher, T. M. (2003). Framing: An emerging paradigm or a phase of agenda setting? In S. D. Reese, O. H. Gandy \& A. E. Grant (Eds.), Framing public life: Perspectives on media and our understanding of the social world (pp. 83-94). Mahwah, NJ: Lawrence Erlbaum.

Mahon, M. (1992). Foucault's Nietzschean genealogy: Truth, power, and the subject. New York: State University of New York Press.

Makerere University. (2007). Developing an information infrastructure agenda for Uganda project. Retrieved May 25, 2007 from http:www.makerere.ac.ug/ ics_diiaup/team.htm

Mazlish, B. (1993). An introduction to global history. In B. Mazlish \& R. Buultjens (Eds.), Conceptualizing global history (pp. 1-24). Boulder, CO: Westview Press. 
(1998). Crossing boundaries: Ecumenical, world, and global history. In P. Pomper, R. H. Elphick \& R. T. Vann (Eds.), World history: Ideologies, structures, and identities (pp. 41-52, 236-8). Malden, MA: Blackwell.

Mazzeo, D. (1975). Foreign assistance and the East African common services, 1960-1970. Munich, Germany; Weltforum Verlag.

McChesney, R. W. (1997). Corporate media and the threat to democracy. New York: Seven Stories Press.

. (1999). Rich media, poor democracy: Communication politics in dubious times. Urbana: University of Illinois Press.

. (2004). The problem of the media: U.S. communication politics in the twenty-first century. New York: Monthy Review Press.

(2007). Communication revolution: Critical junctures and the future of media. New York: New Press.

McChesney, R. W. \& Hackett, R. A. (2005). Beyond wiggle room: American corporate media's democratic deficits, its global implications, and prospects for reform [an interview of R. A. McChesney by R. A. Hackett]. In R. A. Hackett \& Y. Zhao (Eds.), Democratizing global media: One world, many struggles (pp. 225-244). Lanham, MD: Rowman \& Littlefield.

McChesney, R. W. \& Herman, E. S. (1997). The global media: The missionaries of corporate capitalism. Washington, DC: Cassell.

McCombs, M. \& Ghanem, S. I. (2003). The convergence of agenda setting and framing. In S. D. Reese, O. H. Gandy \& A. E. Grant (Eds.), Framing public life: Perspectives on media and our understanding of the social world (pp. 67-81). Mahwah, NJ: Lawrence Erlbaum.

McHenry Jr., D. E. (2004). Political parties and party systems. In P. J. Kaiser \& F. W. Okumu (Eds.), Democratic transitions in East Africa (pp. 38-63). Burlington, VT: Ashgate.

McHoul, A. \& Grace, W. (1993). A Foucault primer: Discourse, power and the subject. New York: New York University Press.

McLeod, D. M. \& Detenber, B. H. (1999). Framing effects of television news coverage of social protest. Journal of Communication, 49(3), 3-23.

McPhail, T. L. (2006). Global communication: Theories, stakeholders, and trends (2nd ed.). Malden, MA: Blackwell. 
Messner, D. \& Nuscheller, F. (2002). World politics-structures and trends. In P. Kennedy, D. Messner \& F. Nuscheller (Eds.), Global trends and global governance (pp. 125-155). London: Pluto Press \& Development and Peace Foundation.

Miller, M. M. \& Riechert, B. P. (2003). The spiral of opportunity and frame resonance: Mapping the issue cycle in news and public discourse. In S. D. Reese, O. H. Gandy \& A. E. Grant (Eds.), Framing public life: Perspectives on media and our understanding of the social world (pp. 107-121). Mahwah, NJ: Lawrence Erlbaum.

M'Mbayo, R. T., Onwumechili, C. \& Nwanko R. N. (Eds.). (2002). Press and politics in Africa. New York: Edwin Mellen.

Moggi, P. \& Tessier, R. (2001). Media status report: Kenya. Nairobi, Kenya: Tangaza College, Catholic University of East Africa. Retrieved January 17, 2006 from http://www.gret.org

Mosco, V. (1996). The political economy of communication: Rethinking and renewal. Thousand Oaks, CA: Sage.

Mouffe, C. (1979). Introduction: Gramsci today. In C. Mouffe (Ed.), Gramsci and Marxist theory (pp. 1-18). London: Routledge \& Kegan Paul.

. (1981). Hegemony and ideology in Gramsci. In T. Bennett, G. Martin, C. Mercer, \& J. Woolacott (Eds.), Culture, ideology and social process (pp. 219-234). London: B. T. Batsford.

Mudibo, E. K. (2005). Report on corporate governance in co-operatives: The East African experience. Paper presented to the Third Pan African Consultative Forum on Corporate Goverance, Dakar, Senegal, November 8-10, 2005. Retrieved November 5, 2007 from http://www.ifc.org/ifcex/cgf.nsf/AttachmentsByTitle/ Pan_Africa_2005_Presentation_Edward_K_Mudibo_doc/\&FILE/Edward+K+(coops).doc

Mustafa, M., Laidlaw, B., \& Brand, M. (1997). Telecommunications policies for sub-Saharan Africa. Washington, DC: World Bank.

Nation Media Group. (2004). Annual report. Nairobi, Kenya: Nation Media Group. (2006). Annual report. Nairobi, Kenya: Nation Media Group.

Nduati, C. \& Bowman, W. (2005). Working from the sidelines: The Kenya Private Sector Foundation Board story. In F. Etta \& L. Elder (Eds.), At the crossroads: ICT policymaking in East Africa (pp. 56-67). Nairobi, Kenya: East African Education Publishers. Retrieved January 25, 2007 from: http://www.idrc.ca/openebooks/ 219-8/\#page_56. 
Nelson, T. E. \& Willey, E. A. (2003). Issue frames that strike a value balance: A political psychology perspective. In S. D. Reese, O. H. Gandy \& A. E. Grant (Eds.), Framing public life: Perspectives on media and our understanding of the social world (pp. 35-65). Mahwah, NJ: Lawrence Erlbaum.

Noakes, J. A. \& Johnston, H. (2005). Frames of protest: A road map to a perspective. In J. A. Noakes \& H. Johnston (Eds.), Frames of protest: Social movements and the framing perspective (pp. 205-211). Lanham, MA: Rowman \& Littlefield.

Nolan, C. J. (2002). The Greenwood encyclopedia of international relations, volume IV (S-Z). Westport, CT: Greenwood.

Nyong'o, P. A. (1989). State and society in Kenya: The disintegration of the nationalist coalitions and the rise of presidential authoritarianism, 1963-78. African Affairs, $88(351), 229-251$.

Ochudho, S. \& Matunga, M. (2005). A national orchestra? Civil society involvement in ICT policy making. In F. Etta \& L. Elder (Eds.), At the crossroads: ICT policymaking in East Africa (pp. 68-83). Nairobi, Kenya: East African Education Publishers. Retrieved January 25, 2007 from: http://www.idrc.ca/openebooks/ 219-8/\#page_68.

Ocitti, J. (2005). Press politics and public policy in Uganda: The role of journalism in democratization. New York: Edwin Mellen Press.

Odhiambo, L. O. (2002). The media environment in Kenya since 1990. African Studies, 61(2), 295-318.

Ogbondah, C. W. (2002). Media law in political transition. In G. Hyden, M. Leslie, \& F. F. Ogundimu (Eds.), Media and democracy in Africa (pp. 55-80). New Brunswick, NJ: Transaction Publishers.

Ogundimu, F. F. (1996). Private-enterprise broadcasting and accelerating dependency: Case studies from Nigeria and Uganda. International Communication Gazette, 58(3), 159-172.

. (2002). Media and democracy in Twenty-First-Century Africa. In G. Hyden, M. Leslie, \& F. F. Ogundimu (Eds.), Media and democracy in Africa (pp. 207-238). New Brunswick, NJ: Transaction Publishers.

O’Malley, P., Weir, L. \& Shearing, C. (1997). Governmentality, criticism, politics. Economy and Society, 26(4), 501-517. 
O'Rourke, K. H. (2007). Economic globalization. In R. Robertson \& J. A. Scholte (Eds.), Encyclopedia of globalization, vol. 1 (pp. 357-363). New York: Routledge.

O'Siochru, S.O., Girard, B., \& Mahan, A. (2002). Global media governance: A beginner's guide. Lanham, MA: Rowman \& Littlefield.

Pan, Z. \& Kosicki, G. M. (2003). Framing as a strategic action. In S. D. Reese, O. H. Gandy \& A. E. Grant (Eds.), Framing public life: Perspectives on media and our understanding of the social world (pp. 35-65). Mahwah, NJ: Lawrence Erlbaum.

Patridge, E. (1961). Origins: A short etymological dictionary of modern English (3rd ed.). London: Routledge \& Kegan Paul.

Phillips, P. \& Project Censored. (2006). Censored 2006: The top 25 censored stories. New York: Seven Stories.

Pratt, C. B. (1996). Africa south of the Sahara. In J. P. Jetter, K. R. Rampal, V. C. Cambridge, \& C. B. Pratt (Eds.), International Afro mass media: A reference guide (pp. 3-61). Westport, CT: Greenwood Press.

Price, V., Tewsksbury, D., \& Powers, E. (1997). Switching trains of thought: The impact of news frames on readers' cognitive responses. Communication Research, 24(5), 481-506.

Prior, L. (2003). Using documents in social research. Thousand Oaks, CA: Sage.

Ransome, P. (1992). Antonio Gramsci: A new introduction. New York: Harvester Wheatsheaf.

Reese, S. D. (1990). The news paradigm and the ideology of objectivity: A socialist at The Wall Street Journal. Critical Studies in Mass Communication, 7(4), 390-409. . (2003). Prologue-Framing public life: A bridging model for media research. In S. D. Reese, O. H. Gandy \& A. E. Grant (Eds.), Framing public life: Perspectives on media and our understanding of the social world (pp. 7-31). Mahwah, NJ: Lawrence Erlbaum.

Reese, S. D. \& Buckalew, B. (1995). The militarism of local television: The routine framing of the Persian Gulf War. Critical Studies in Mass Communication, 12(1), 40-59.

Roberts, J. S. (1974). Kenya. In S. W. Head (Ed.), Broadcasting in Africa: A continental survey of radio and television (pp. 54-61). Philadelphia: Temple University Press. 
Rogers, E. M. (1994). A history of communication study: A biographical approach. New York: Free Press.

Room, A. (2002). Cassell's dictionary of word histories (2nd ed.). London: Cassell.

Roosevelt, F. D. (1941). No peace with Hitler: Eight common principles for a better world. Vital Speeches of the Day, 7(22), 678-9.

Rose, N. (1988).Calculable minds and manageable individuals. History of the Human Sciences, 1(2), 179-200. (1999). Powers of freedom: Reframing political thought. New York: Cambridge University Press.

Rose, N. \& Miller, P. (1990). Governing economic life. Economy and Society, 19(1), 1-31.

. (1992). Political power beyond the state: Problematics of government. British Journal of Sociology, 43(2), 173-205.

(1995). Production, identity and democracy. Theory and Society, $24(3), 427-467$.

Rosenblum, N. L. (1995). Liberalism. In S. M. Lipset (Ed.), The encyclopedia of democracy (pp. 756-761). Washington, D.C.: Congregational Quarterly.

Ryfe, D. M. (2001). History and political communication: An introduction. Political Communication, 18(4), 407-420.

Sanghera, B. (2004). Introduction to the philosophy of social research. Almaty, Kazakhstan: Central Asian Resource Centre. Retrieved April 2, 2006 from http:// www.uk.geocities.com/ balibar_sanghera.

Sartori, G. (1987). The theory of democracy revisited. Chatham, NJ: Chatham House Publishers.

Sawe, D. (2005). The eThinkTank and ICT policy making in Tanzania. In F. Etta \& L. Elder (Eds.), At the crossroads: ICT policymaking in East Africa (pp. 250-256). Nairobi, Kenya: East African Education Publishers. Retrieved January 25, 2007 from http://www.idrc.ca/ openebooks/219-8/\#page_68.

Scheufele, D. A. (1999). Framing as theory of media effects. Journal of Communication, 49(1), 103-122. 
. (2000). Agenda-setting, priming, and framing revisited: Another look at cognitive effects of political communication. Mass Communication \& Society, 3(2/3), 297316.

Scott, J. \& Marshall, G. (2005). Oxford dictionary of sociology. New York: Oxford University Press.

Semetko, H. A.\& Valkenburg (2000). Framing European politics: A content analysis of press and television news. Journal of Communication, 50(2), 93-109.

Severin, W. J. \& Tankard, J. W. (2001). Communication theories: Origins, methods, and uses in the mass media (5th ed.) New York: Longman.

Shah, D. V., Domke, D. \& Wackman, D. B. (2003). The effects of value-framing on political judgment and reasoning. In S. D. Reese, O. H. Gandy \& A. E. Grant (Eds.), Framing public life:Perspectives on media and our understanding of the social world (pp. 227-243). Mahwah, NJ: Lawrence Erlbaum.

Shade, L. R. (2006). O Canada: Media (de)convergence, concentration, and culture. In P. Attallah \& L. R. Shade (Eds.), Mediascapes: New patterns in Canadian communication (2nd ed., pp. 346-364). Toronto, Ontario, Canada: Thomson/ Nelson.

Simai, M. (1994). The future of global governance: Managing risk and change in the international system. Washington, DC: United States Institute of Peace Press.

Simon, R. (1991). Gramsci's political thought: An introduction. London: Lawrence \& Wishart.

Skeat, W. W. (1911). A concise etymological dictionary of the English language. Oxford, UK: Clarendon Press.

Snow, D. A. (2004). Framing process, ideology and discursive fields. In D. A. Snow, S. A. Soule, \& H. Kriesi (Eds.), The Blackwell companion to social movements (pp. 380-412). Malden, MA: Blackwell.

Snow, D. A., \& Benford, R. A. (1988). Ideology, frame resonance, and participant mobilization. In B. Klamdermans, H. Kriesi, \& S. Tarrow (Eds.), International social movement research, volume 1 (pp. 197-217). Greenwich, CT: Jai Press.

(1992). Master frames and cycles of protest. In A. D. Morris \& C. M. Muller (Eds.), Frontiers in social movement theory (pp. 133-54). New Haven, CT: Yale University Press. 
. (2000). Framing processes and social movements: An overview and assessment. Annual Review of Sociology, 26, 611-39.

. (2005). Clarifying the relationship between framing and ideology. In H. Johnston \& J. A. Noakes (Eds.), Frames of protest: Social movements and the framing perspective (pp. 205-211). Lanham, MA: Rowman \& Littlefield.

Snow, D. A, Benford, R. A., Rochford, E. B. \& Worden, S. K. (1986). Frame alignment processes, micromobilization and movement participation. American Sociological Review, 51(4), 464-81.

Socialist International (1968 [1951]). The 1951 Frankfurt Declaration. In S. Massimo (Ed.), Modern socialism (pp. 279-289). New York: Harper Torchbooks.

Solso, R. L. \& MacLin, O. H. (2000). Cognitive psychology: History of the field. In A. E. Kazdin (Ed.), Encyclopedia of psychology, volume 2 (pp. 150-153). Washington, DC: American Psychological Association.

Steger, M. B. (2002). Globalism: The new market ideology. Lanham, MA: Rowman \& Littlefield.

Strahm, A. (2005). Political economy of mass media: FCC ownership review-the debates. In P. Phillips \& Project Censored, Censored 2006: The top 25 censored stories (pp. 337-353). New York: Seven Stories

Strickland, C. F. (1933). Co-operation for Africa. Africa: Journal of the International African Institute, 16(1), 15-26.

(1935).The co-operative movement in Africa. Journal of the Royal African Society, 34(134), 1-18.

Sturmer, M. (1998). The media history of Tanzania. Ndanda, Tanzania: Ndanda Mission Press.

Tanganyika African National Union. (1967). The Arusha declaration and TANU's policy on socialism and self-reliance. Dodoma, Tanzania: Tanyanyika African National Union.

Tankard, J. W. (2003). The empirical approach to the study of media framing. In S. D. Reese, O. H. Gandy \& A. E. Grant (Eds.), Framing public life: Perspectives on media and our understanding of the social world (pp. 95-106). Mahwah, NJ: Lawrence Erlbaum.

Tanzania Communications Regulatory Authority. (2007). Statistics. Retrieved February 17, 2007 from http://www.tcra.go.tz/publications/statistics.php 
Tanzania Telecommunications Company Limited. (2007). TTCL background. Retrieved February 2007 from http://www.ttcl.co.tz/about_background.asp

Tanzanian Electronic Networking Community. (2004). The media in Tanzania. Retrieved February 17, 2007 from http://www.tanzanet.org/modules.php?name= Tanzania_media

Telkom South Africa. (2007). Acquisition of Africa Online. Retrieved March 31, 2007 from https.//secure1.telkom.co.za/ir/nes/pdf/sensarticle_197.pdf

Thompson, K. (1997). Regulation, de-regulation and re-regulation. In K. Thompson (Ed.), Media and cultural regulation (pp. 10-68). London: Sage.

Tickell, A. \& Peck, J. (2003). Making global rules: Globalization or neoliberalization? In J. Peck \& H. W-C. Yeung (Eds.), Remaking the global economy: Economicgeographical perspectives (pp. 161-181). Thousand Oaks: Sage.

Todd, A. (2002). The European dictatorships: Hitler, Stalin, Mussolini. Cambridge, UK: Cambridge University Press.

Tuchman, G. (1978). Making news: A study in the construction of reality. New York: Free Press.

Uganda Communications Commission. (2007). Communications sector comparative figures for the period December 1996 to March 2007. Retrieved July 10, 2007 from http://www.ucc.co.ug/marketInfo/marketstatistics.php

United Nations. (2007). East Africa. Retrieved June 28, 2007 from http://www.un.org/Depts/Cartographic/map/profile/eastafri.pdf

United Nations Economic Commission for Africa. (1999). Developing national information and communications infrastructure (NICI): Policies, plans and strategies-The "why" and "how". Addis Ababa, Ethiopia: United Nations Economic Commission for Africa. Retrieved January 5, 2007 from http://www.uneca.org/aisi/nici/Documents/ NICI\%20in\%20Africa.htm.

. (2003 [1996]). African Information Society Initiative (AISI): An action framework to build Africa's information and communication infrastructure. Addis Ababa, Ethiopia: United Nations Economic Commission for Africa. Retrieved January 5, 2007 from http://www.uneca.org/aisi/docs/AISIBrochure.pdf.

. (2003, January). Towards an information society in Africa: The case for national policies. AISI Briefing Papers, 1. Retrieved January 5, 2007 from $\mathrm{http}: / / \mathrm{www}$.uneca.org/aisi/docs/AISI BriefingPaperNo1.PDF. 
(2007). Africa Information Society Initiative (AISI) e-strategies. Retrieved January 5, 2007 from http://www.uneca.org/aisi/NICI/main.html

van der Veur, P. R. (2002). Broadcasting and political reform. In G. Hyden, M. Leslie \& F. F. Ogundimu (Eds.), Media and democracy in Africa (pp. 81-105). New Brunswick, NJ: Transaction.

van der Zweerde, E. (2006). Civil society. In T. M. Leonard (Ed), Encyclopedia of the developing world (pp. 346-348). New York: Routledge.

van Loon, B. \& Osborne, R. (1999). Introducing sociology. New York: Totem Books.

Waema, T. M. (2005). A brief history of the development of an ICT policy in Kenya. In F. Etta \& L. Elder (Eds.), At the crossroads: ICT policymaking in East Africa (pp. 25-43). Nairobi, Kenya: East African Education Publishers. Retrieved January 25, 2007 from http://www.idrc.ca/openebooks/219-8/\#page_44.

Walters, W. (2002). The power of inscription: Beyond social construction and deconstruction in European integration studies. Millennium: Journal of Intenational Studies, 31(1), 83-108.

Webster, F. (2006). Theories of the information society (3rd ed.). New York: Routledge.

Wicks, R. H. (2005). Message framing and constructing meaning: An emerging paradigm in mass communication research. Communication Yearbook, 29, 331-361.

Williamson, J. (1990). What Washington means by policy reform. In J. Williamson (Ed.), Latin American adjustment: How much has happened? (pp. 7-38). Washington, DC: Institute for International Economics.

. (1997). The Washington consensus revisited. In L. Emmerij (Ed.), Economic and social development into the XXI Century (pp. 48-59). Washngton, DC: InterAmerican Development Bank.

Wilson, J. (1973). Introduction to social movements. New York: Basic Books.

Wilson, T. A. (1991). The first summit: Roosevelt and Churchill at Placenta Bay, 1941. Lawrence, KS: University Press of Kansas.

Winter-Nelson, A. (2003). Debt crises. In P. A. Zeleza \& D. Eyok (Eds.), Encyclopedia of twentieth-century African history (pp. 132--135). London: Routledge.

World Association of Newspapers. (2003). World press trends 2003. Paris, France: World Association of Newspapers. 
. (2004). World press trends 2004. Paris, France: World Association of Newspapers.

World Bank. (1989). Sub-Saharan Africa: From crisis to sustainable growth-A longterm perspective study. Washington, DC: World Bank.

. (1994). World development report: Infrastructure for development. Washington, DC: World Bank.

. (1996a). World development report: From plan to market. Washington, DC: World Bank.

. (1996b). World debt tables: External finance for developing countries, vol 2. Washington, DC: World Bank.

. (1997). World development report. The state in a changing world. Washington, DC: World Bank.

. (1999 / 2000). World development report: Entering the 21st century-The changing development landscape. Washington, DC: World Bank.

(2001). National information infrastructure agenda report, vol 1. Washington, DC: World Bank.

. (2002a). World development report 2002: Building institutions for markets. Washington, DC: World Bank.

(2002b). Globalization, growth, and poverty: Building an inclusive world economy. Washington, DC: World Bank.

(2002c). Information and communications technologies: A World Bank strategy. Washington, DC: World Bank.

. (2002d). The right to tell: The role of mass media in economic development. Washington, DC: World Bank.

(2005a). World development report: A better investment climate for all. Washington, DC: World Bank.

. (2005b). Issues and options for improving engagement between the World Bank and civil organizations. Washington, DC: World Bank.

Zaffiro, J. J. (2002). Media \& democracy in Zimbabwe, 1931-2002. Colorado Springs, CO: International Academic Publishers.

Zanzibar Telecommunications Company. (2007). Company profile. Retrieved July 10, 2007 from http://www.zantel.co.tz/profile.html 
Zartman, I. W. (1995). Introduction: Posing the problem of state collapse. In I. W. Zartman (Ed.), Collapsed states: The disintegration and restoration of legitimate authority (pp. 1-11). Boulder, CO: Lynne Rienner. 